\title{
20. PETROLOGY OF THE BASALTIC ROCKS DRILLED ON LEG 33 OF THE DEEP SEA DRILLING PROJECT
}

\author{
Everett D. Jackson, Keith E. Bargar, Brent P. Fabbi, and Chris Heropoulos, \\ U.S. Geological Survey, Menlo Park, California
}

\begin{abstract}
Six flow units of basalt were penetrated at the base of Hole 315A, located near Fanning Island in the Line Islands chain; intercalated sedimentary rocks, if present, were not recovered. Ten flow units of basalt were penetrated in Hole 317A, located on the high Manihiki Plateau; four of these flow units are intercalated with thin beds of baked volcaniclastic siltstone. Basement was not reached in Hole 316, near Christmas Island in the Line Islands chain, nor in Hole 318, between Ahe and Arutua atolls in the Tuamotu Islands chain, but centimeter-sized pebbles of volcanic rocks were recovered from breccia beds at both these sites. The basaltic rocks in Hole $315 \mathrm{~A}$ are highly altered, chiefly to montmorillonite group minerals and calcite, but not to the extent that their textures, original mineralogy, and major- and minor-element abundances could not be established. The flow units show textural differences, but their composition is similar to basalts of the oceanic island type, intermediate between Hawaiian tholeiite and alkalic basalt. The pebbles of Hole 316 may also be of this type. These basalts are much less alkalic than the amphibolebearing basalts drilled in the more northerly Line Islands on Leg 17, which appear to resemble Hawaiian post-erosional basanites and nephelinites. It would appear from existing analyses that the Line Islands are composed of basaltic rocks that are very similar to those of the Hawaiian chain.

Basalts drilled in Hole 317A differ in character from those of Hole $315 \mathrm{~A}$. They are less altered, and their textures, mineralogy, and major and minor element compositions unquestionably show them to be basalts of the oceanic ridge tholeiite type. They resemble basalts drilled beneath the Ontong-Java Plateau during Leg 30. Basalts from both areas are similar to rocks forming at present-day spreading centers, and do not support the contention that these plateaus are subsided microcontinents. The basalts are, however, exceedingly vesicular, and must have been erupted at water depths of less than 400 meters, or perhaps even subaerially. This implies that the Manihiki Plateau has subsided between 3000 and 3500 meters during the last 110 to 120 m.y.

Basaltic pebbles from the northwestern end of the Tuamotu chain are also of the oceanic island type. Age data down the chain are scanty, and it is not possible at present to say whether this part of the Tuamotu chain is of the progressively propagating type.
\end{abstract}

\section{INTRODUCTION}

Of the four deep holes drilled on Leg 33, all bottomed in or passed through thick sections of volcaniclastic sediments. Hole $315 \mathrm{~A}$ penetrated about 110 meters of this material before basalt flows were reached; Hole 316 penetrated more than 250 meters of this material and was abandoned before reaching basement; in Hole 317A considerable amounts of volcanogenic debris are interbedded with calcareous material more than 260 meters above the contact with the uppermost basalt flow; in Hole 318 nearly 200 meters of predominantly volcaniclastic sediments were penetrated at the bottom of the hole before drilling was terminated. The petrology of these volcaniclastic silts and sands is described in other sections of this report (Kelts and McKenzie, this volume; Jenkyns, this volume). One centimeter-sized basalt fragment was recovered from Hole 316, and two fragments of similar size were recovered from Hole 318; none of these samples was large enough for work other than that permitted by thin section and X-ray techniques, and descriptions of these three fragments are discussed separately in a later section of this paper. The main body of this report deals with the geologic setting, petrography, mineralogy, and chemical composition of the basaltic flows recovered from Hole $315 \mathrm{~A}$ in the Line Islands and from Hole 317A beneath the Manihiki Plateau. 


\section{GEOLOGIC SETTING AND STRATIGRAPHY OF FLOW UNITS}

\section{Hole 315A}

Hole $315 \mathrm{~A}$ is located $93 \mathrm{~km}$ northeast of Fanning Island, and both bathymetry and reflection profiles suggested that basement here would consist of lava flows associated with the Fanning edifice rather than flat-lying oceanic crust. The generally elevated nature of the basement at this site and its smooth slope away from Fanning Island were our principal criteria in choosing the location. The volcaniclastic debris (see Kelts and McKenzie, this volume) is compositionally similar to the mildly alkalic basalts penetrated in Hole 315A, suggesting that the debris was derived from the Fanning edifice. The age of the basalts based on extrapolated accumulation rates beneath the lowest identifiable fossils is $\sim 85 \mathrm{~m}$.y. (see Part I of this volume), and that age has been generally confirmed by K/Ar ages of $91.2 \pm 2.7$ m.y. reported by Lanphere and Dalrymple (this volume).

Hole $315 \mathrm{~A}$ entered basalt at a depth of 996.3 meters below the mudline in the lower $20 \mathrm{~cm}$ of Core $30 \mathrm{~A}$ (Figure 1). A total of 38 meters of basalt were penetrated, and 7.6 meters recovered. Although recovery was poor, the lack of correlation between drilling rate and recovery led us to believe that no sedimentary material is present below Core 30A (see Table1).

Six flow units were tentatively identified aboard ship (Figure 2), and subsequent petrologic study has shown no reason to revise this stratigraphy. The basalt at the base of Core 30A (Flow unit 1A) appears identical to that of Core $31 \mathrm{~A}$, and it would seem that the lower part of Core 31A was not recovered, in spite of the slow drilling rate. Core $32 \mathrm{~A}$ began and ended in flow units not seen in either Core $31 \mathrm{~A}$ or Core $33 \mathrm{~A}$, and the loss could have been at either end or both. Core $32 \mathrm{~A}$ contains the only complete flow unit with both altered glass contacts intact (Flow Unit 3); it is 1.5 meters thick. Core 33A contains basalt that appeared identical with that at the top of Core 34A; it seems likely, therefore, that the upper part of Core 33A was unrecovered, and the lower part of Core 34A was lost. If correctly assembled, the thicknesses or minimum thicknesses of flow units are as shown in Table 1.

TABLE 1

Drilling Summary of the Deepest Cores of Hole 315A

\begin{tabular}{lcccc}
\hline Core & $\begin{array}{c}\text { Drilled } \\
\text { Interval } \\
(\mathrm{m})\end{array}$ & $\begin{array}{c}\text { Drilling } \\
\text { Rate } \\
(\mathrm{m} / \mathrm{hr})\end{array}$ & $\begin{array}{c}\text { Recovery } \\
(\%)\end{array}$ & $\begin{array}{c}\text { Flow Unit } \\
\text { Thickness }(\mathrm{m}) \\
(\text { see Figure } 1)\end{array}$ \\
\hline 25A-30A & 57.0 & $4.0-15.0$ & $28.4-54.7$ & $1 \mathrm{~A} \geqslant 0.2$ \\
$31 \mathrm{~A}$ & 9.5 & 42.0 & 5.3 & $\begin{array}{l}1 \mathrm{~B} \geqslant 1.0 \\
2 \geqslant 1.75\end{array}$ \\
$32 \mathrm{~A}$ & 9.5 & 26.0 & 52.6 & $\left\{\begin{array}{l}3 \\
3 \\
4 \geqslant 1.55\end{array}\right.$ \\
$33 \mathrm{~A}$ & 9.5 & 15.0 & 7.4 & $\begin{array}{c}5 \mathrm{~A} \geqslant 1.3 \\
5 \mathrm{~B} \geqslant 0.2 \\
6 \geqslant 1.7\end{array}$ \\
$34 \mathrm{~A}$ & 9.5 & 9.5 & 12.6 &
\end{tabular}

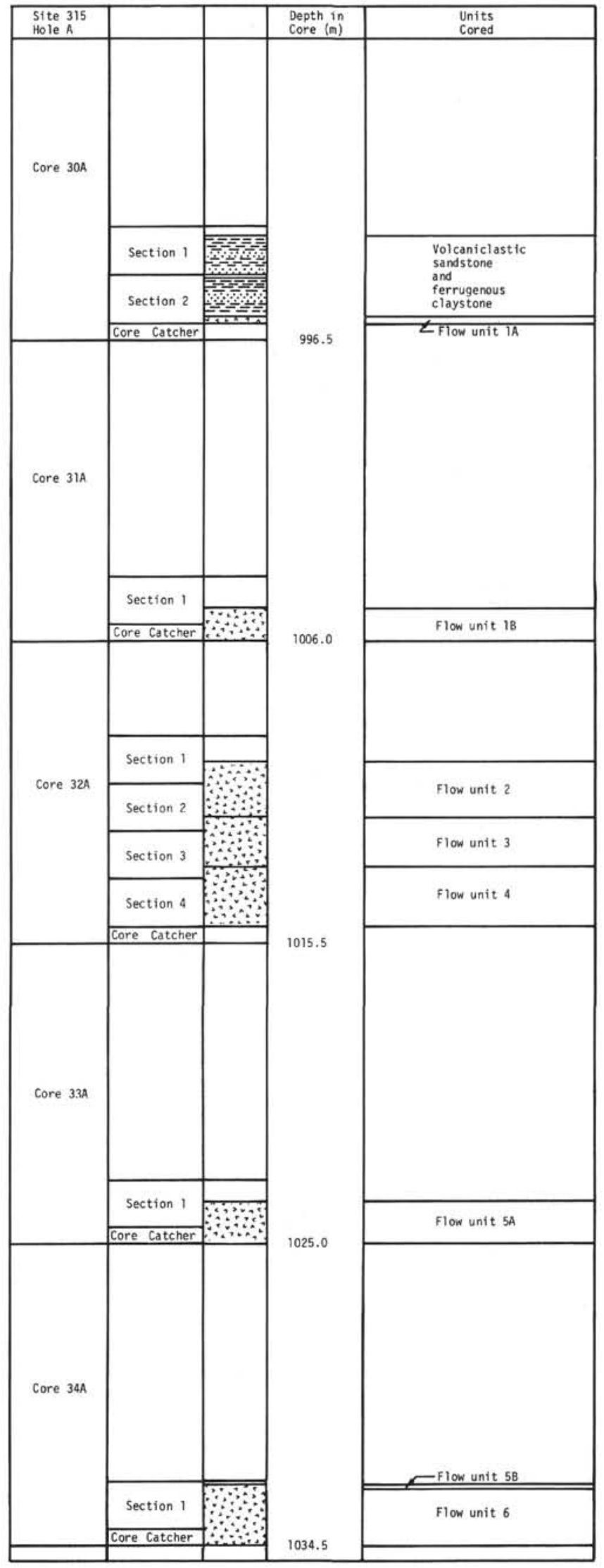

Figure 1. Recovery of cored intervals from the deepest part of Hole $315 \mathrm{~A}$. 


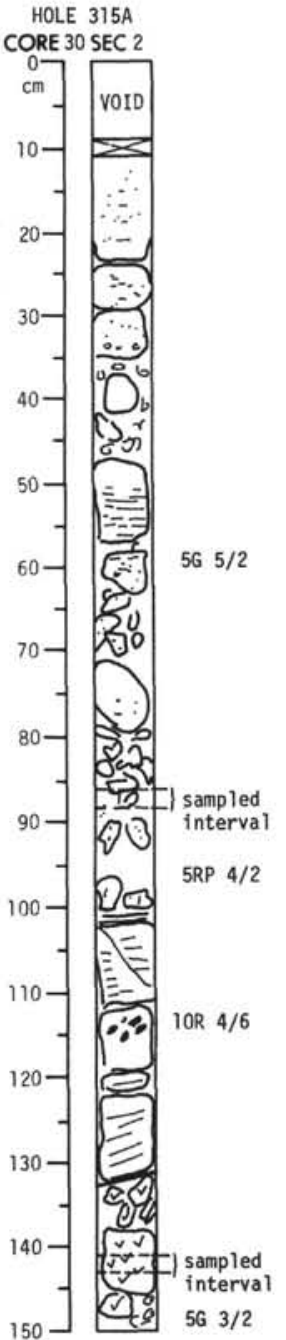

Figure 2. Visual core description of basaltic rocks and associated sedimentary rocks of Hole 315A. Sampled intervals below sections are core-catcher samples from the deepest part of Hole $317 \mathrm{~A}$.

\section{Hole 317A}

Hole 317A was drilled near the center of the Manihiki Plateau, about midway between the Danger-Nassau, Manihiki-Rakahanga island groups, and Suvarov island, all low corraline islands that bound the plateau. The geologic setting of the Manihiki Plateau has recently been described by Winterer et al. (1974) and Jenkyns (this volume). The petrology of basalts dredged from more northerly parts of the plateau is given by Clague (this volume).

Basalt was penetrated in Hole 317A at a depth of 910 meters in the lower 4.6 meters of Core 31A (Figure 3). A total of 28.5 meters of penetration below Core 31A revealed a section that consists largely of basalt but contains several intercalated beds of baked volcaniclastic siltstone (Figure 4). In the total core recovered below the first contact with basalt, three such sedimentary units were noted, two in Core 31A and one in Core 33A. Recovery in general was good, and there appeared to be some correlation between drilling rate and recovery in

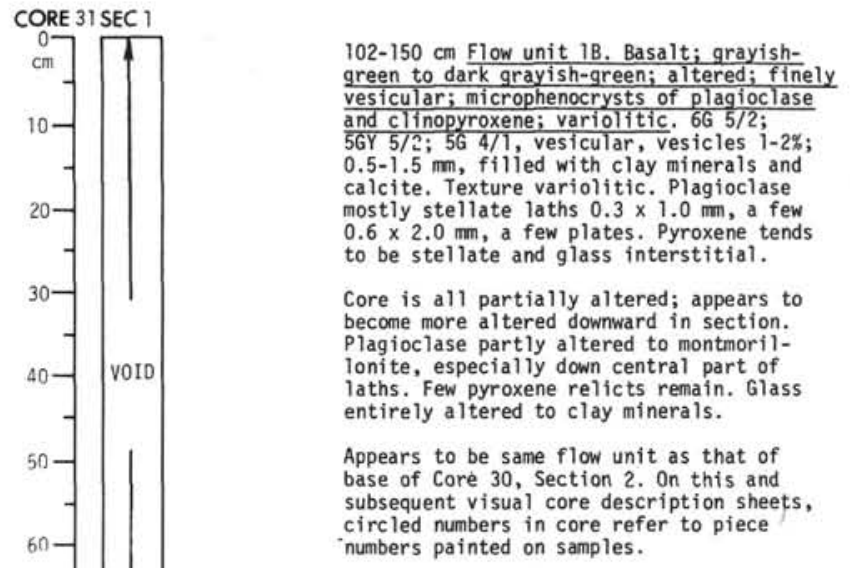

$565 / 2$

$=$ sampled

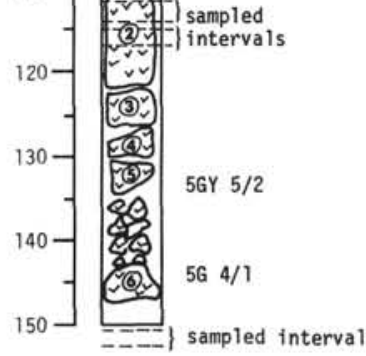

Figure 2. (Continued).

this hole (see Table 2). Drilling rates in basalt in both Holes $315 \mathrm{~A}$ and $317 \mathrm{~A}$ were faster than we had anticipated; rates in $317 \mathrm{~A}$ basalt were, in general, faster than those in $315 \mathrm{~A}$, which contains more altered basalt.

Ten flow units were identified aboard ship (Figure 4), and subsequent petrologic studies have shown no reason to change this stratigraphy. Magnetic studies (Cockerham and Jarrard, this volume) show that the entire core is normally magnetized. The missing part of the section of Core $31 \mathrm{~A}$ probably represents volcaniclastic sediments above and between flow units (see Figure 4). Core $32 \mathrm{~A}$ was full, and the basalt at its top appears identical with that at the base of Core $31 \mathrm{~A}$. The basalt at the top of Core $33 \mathrm{~A}$ appears identical to that at the base of Core $32 \mathrm{~A}$ and probably belongs at the top of the core. Some section is surely missing at the base of the volcaniclastic sandstone (Figures 3 and 4), and this probably accounts for much of the missing interval in Core $33 \mathrm{~A}$. The flow unit at the top of Core 34A appears identical with that at the base of Core $33 \mathrm{~A}$, and the missing interval in that core is most likely near its base. If correctly assembled, the thicknesses or minimum thicknesses of flow units are as shown in Table 2. 


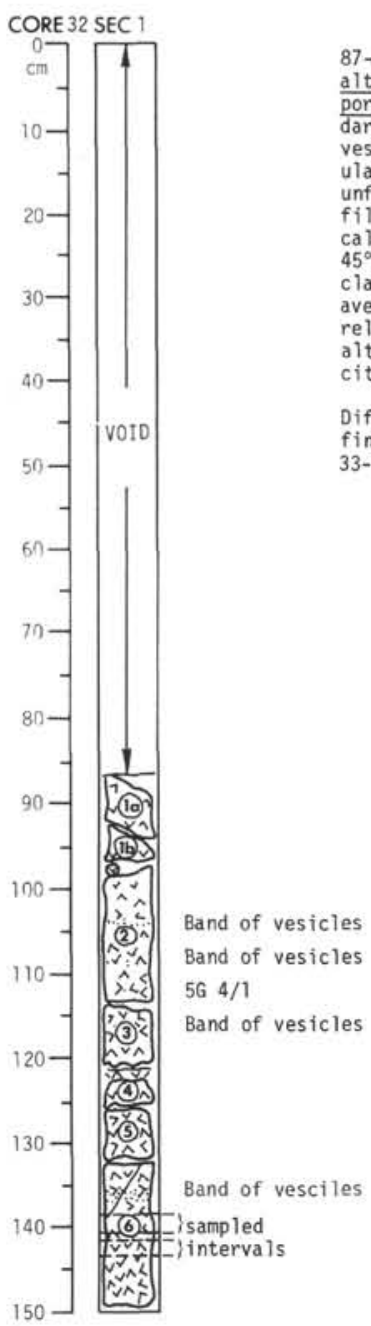

Figure 2. (Continued).

\section{X-RAY DIFFRACTION DATA AND PETROGRAPHY OF HOLES 315A AND 317A}

\section{Introduction}

Samples from the six flow units of Hole 315A and the ten flow units of Hole $317 \mathrm{~A}$ were rather limited in number. In most cases, two core plugs of $2.5 \mathrm{~cm}$ outside diameter (each plug weighing about $40 \mathrm{~g}$ ) were made available from each flow unit. For each hole, however, one quarter core of the freshest flow unit was cut for wet-chemical analyses and for plagioclase separations for $\mathrm{K} / \mathrm{Ar}$ analyses (see Figures 2 and 4 for sampled intervals, and Lanphere and Dalrymple, this volume, for results).

X-ray diffraction studies, petrographic examination, and chemical analyses for both major and minor elements show only small internal differences between the basalts of either site. However, the basalts from the two sites are vastly different in character from each other. Basalts from Hole $315 \mathrm{~A}$ are salite-bearing transitional basalts with relatively high $\mathrm{K}_{2} \mathrm{O}$ contents, and most nearly resemble rocks transitional between Hawaiian tholeiites and pre-erosional Hawaiian alkalic basalts. They have a chemical affinity to the hawaiites and

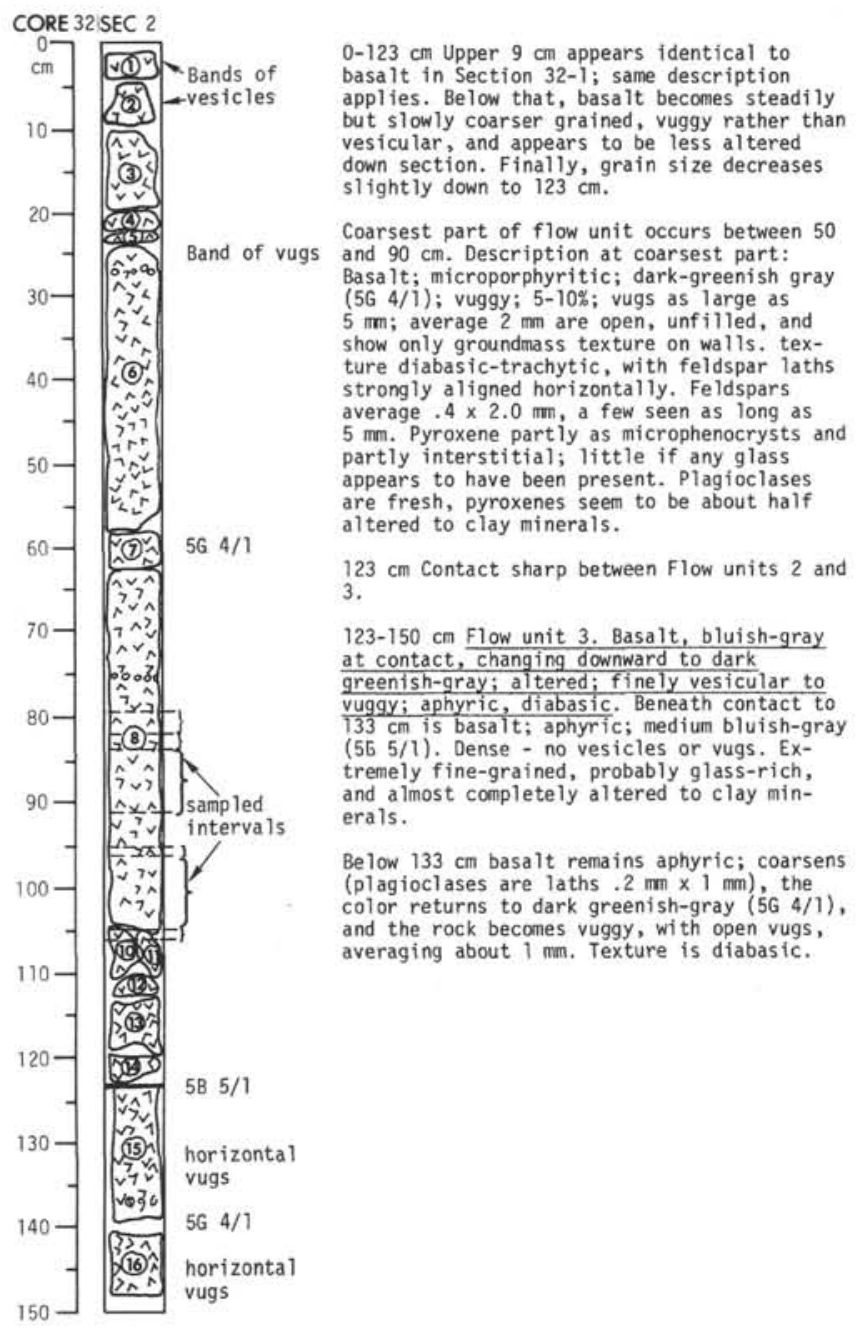

Figure 2. (Continued).

mugearites reported by Bass et al. (1973) from Site 165, although they are much less strongly alkalic. Basalts from Hole $317 \mathrm{~A}$, on the other hand, are oceanic ridge tholeiites with very low $\mathrm{K}_{2} \mathrm{O}$ values that contain low calcium pyroxenes as well as augite and are similar to basalts from Site 289 beneath the Ontong-Java Plateau (Stoeser, in press).

\section{X-ray Procedures}

Whole-rock samples and vesicle fillings were analyzed by standard X-ray procedures on a Norelco diffractometer with unfiltered $\mathrm{CuK} \alpha$ radiation. One basalt sample was selected from each hole, and its mineral constituents were separated by bromoform (Schoen and Lee, 1964) and magnetic (Hess, 1959) methods. The separated minerals were than X-rayed, and the resulting diffractograms were used as standards for subsequent mineral identifications. Anorthite content of the two separated plagioclases was determined by the method of Jackson (1961) (Tables 3 and 4, at end of chapter).

Several clay vesicle fillings and whole-rock samples that contained abundant clay were glycolated (Bradley, 1945) and X-rayed again. In every case, a comparison of the two diffractograms indicated that all were expanding 


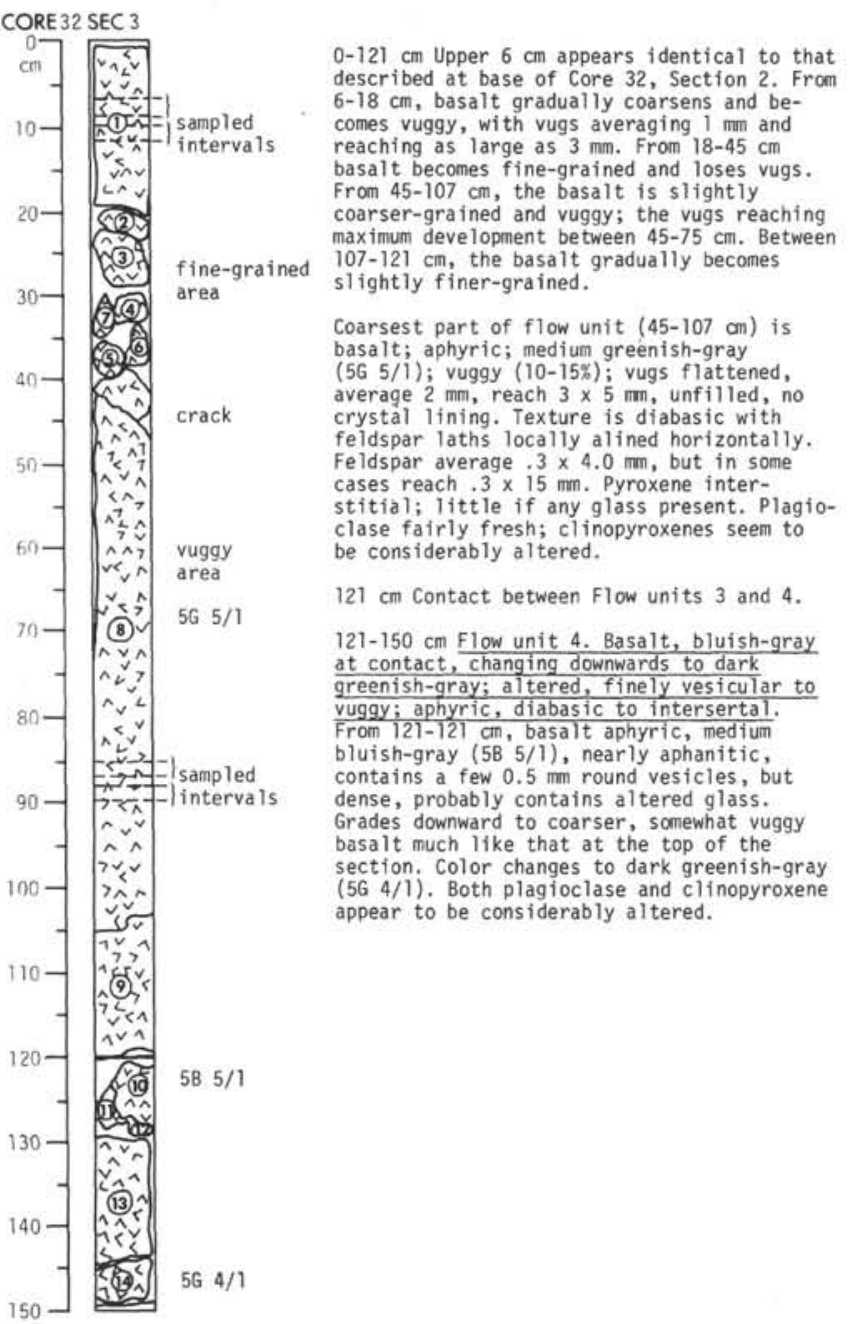

Figure 2. (Continued).

clays of the montmorillonite (smectite) group. Most whole-rock diffractograms showed (001) $d$-values to range generally from 14.5 to $15.5 \AA$, suggesting that $\mathrm{Ca}$ is the exchangeable cation. Only one vesicle filling from each hole had a $\sim 12.5 \AA d$ spacing, suggesting $\mathrm{Na}$ to be the exchangeable ion (Grim, 1968). Several clay samples had (001) $d$-values falling between 12.5 and $14.5 \AA$. Generally these intermediate $d$-values were associated with green vesicle fillings noted in Tables 3 and 4, and, in some cases, with green clay alteration in the groundmass of the basalts. However, the association is less than perfect, inasmuch as some of the green vesicle fillings have $d$-values occurring in the 14.5 to $15.5 \AA$ range. In one sample $(315 \mathrm{~A}-32-4,53-55 \mathrm{~cm})$ partial electron microprobe analyses were made for green vesicle-filling clay and brown clay that had replaced intersertal groundmass. In the green clay, $\mathrm{K}_{2} \mathrm{O}$ averaged $0.05 \%$, $\mathrm{Na}_{2} \mathrm{O}, 1.43 \%$, and $\mathrm{CaO}, 1.06 \%$. In the brown clay, $\mathrm{K}_{2} \mathrm{O}$ averaged $0.08 \%, \mathrm{Na}_{2} \mathrm{O}, 1.13 \%$, and $\mathrm{CaO}, 1.39 \%$. In general, we suspect that the green clays are enriched in $\mathrm{Na}_{2} \mathrm{O}$ and the brown clays are enriched in $\mathrm{CaO}$.

Six of the green clay samples were saturated with $\mathrm{Li}$ following the method of Green-Kelly (1953). The results of these analyses suggest that the clays fall near the

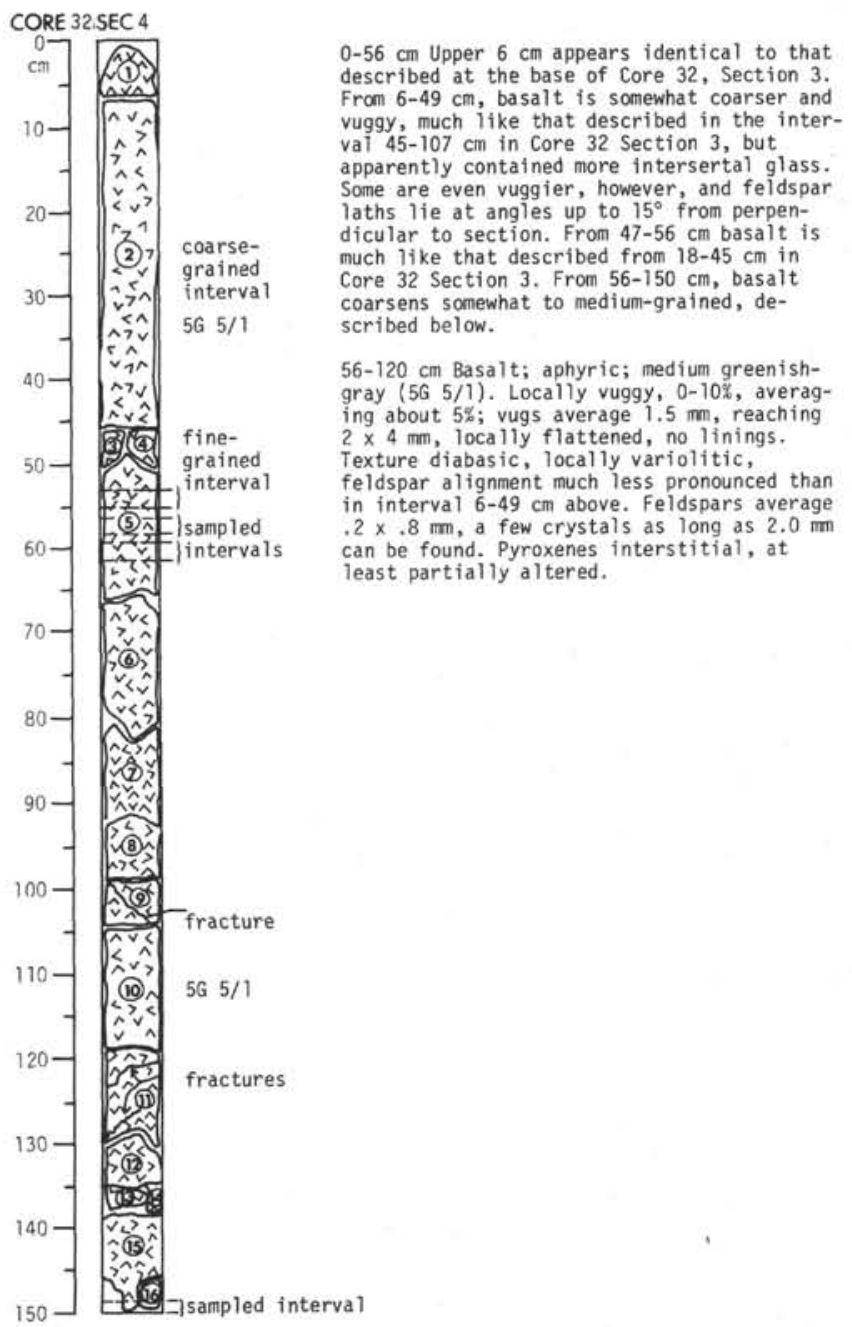

Figure 2. (Continued).

beidellite end of the montmorillonite-beidellite series. However, we were unable to separate pure brown clay minerals for $\mathrm{Li}$ saturation, and we are unable to say whether or not these fall closer to end-member montmorillonite. Hereafter, we simply refer to all clay minerals as montmorillonite, in the sense that it is a group name for expanding clays. The color is noted, where appropriate, to indicate the exchangeable cation.

\section{X-ray Mineralogy, Hole 315A}

$\mathrm{X}$-ray mineral identifications and estimates of approximate order of abundance were made for nine samples from the sedimentary section (Core $22 \mathrm{~A}$ to Core $30 \mathrm{~A}$ ) above the basalts of Hole 315A. Core 22A contains, in order of decreasing abundance, calcite, plagioclase, montmorillonite, magnetite, anatase, and clinoptilolite. ${ }^{1}$ Two samples from Core 23A consist of the some minerals in about the same abundance as observed for Core $22 \mathrm{~A}$, except that anatase is absent. In Core $25 \mathrm{~A}$, the one sample that was X-rayed consists of

'Clinoptilolite was distinguished from heulandite by the method of Mumpton (1960) and Murata and Whitely (1973). 


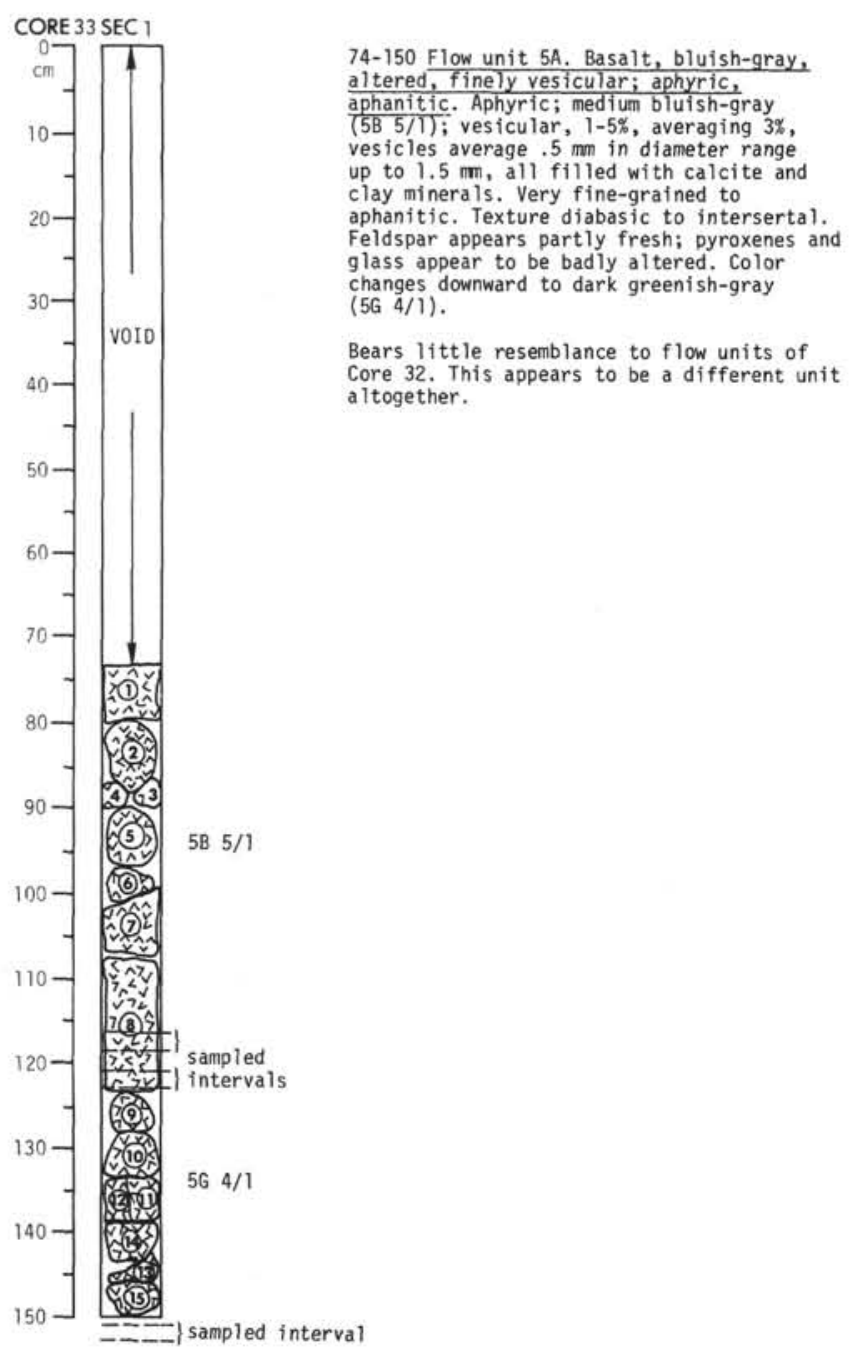

Figure 2. (Continued).

nearly the same minerals as were found in Core $22 \mathrm{~A}$, but plagioclase is subordinate to montmorillonite and clinoptilolite, magnetite is absent, and a small amount of quartz is present. Core $25 \mathrm{~A}$ was the lowest core of the sedimentary section in which calcite was observed. Core $28 \mathrm{~A}$ contains plagioclase and montmorillonite as the dominant minerals, and clinoptilolite and anatase as subordinate components; pyroxene is of intermediate abundance and was identified only in this core. The two samples analyzed from Core $29 \AA$ were very different; one contains only montmorillonite and plagioclase, and the other, quartz and celadonite. Finally, two sedimentary samples from Core $30 \mathrm{~A}$ contain montmorillonite, $\mathrm{K}$-feldspar, and possibly a small amount of anatase.

Three basalt samples were analyzed from Flow Unit $1 \mathrm{~A}$ (Core 30A). These consist predominantly of montmorillonite and plagioclase with lesser amounts of calcite, pyroxene, magnetite, and a trace of anatase, in approximate order of decreasing abundance. X-ray analyses of three whole-rock samples and three vesicle fillings from Flow Unit 1B (Core 31A) indicate that the principal minerals are again montmorillonite and plagioclase with small amounts of magnetite and pyroxene, although identification of the latter mineral is

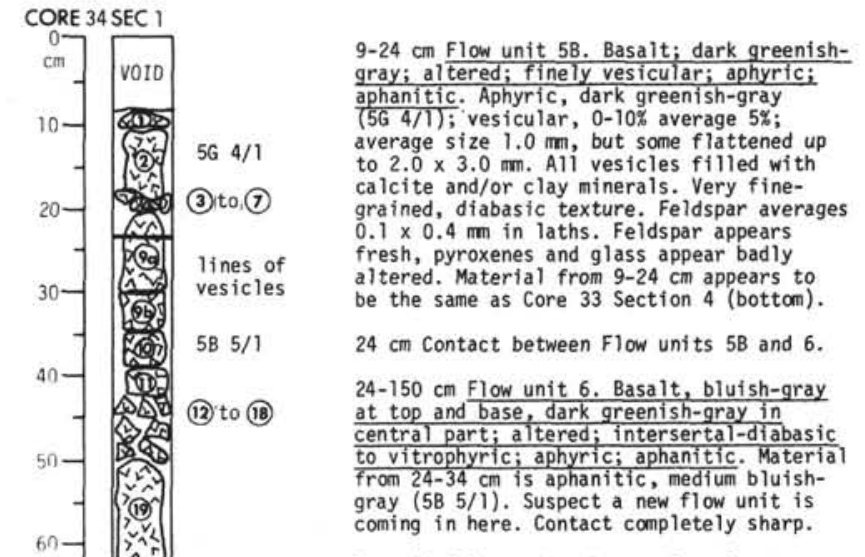

From $34-130 \mathrm{~cm}$ unit changes in color to dark greenish-gray; becomes somewhat coarser and appears to contain more calcite.

Fram $130-150 \mathrm{~cm}$, the unit becomes finergrained, changes in color to medium bluishgray and becomes aphanitic. Feldspars very fine and fresh, groundmass appears to be completely altered glass. Bottam of core may represent the base of flow unit. Becomes vesicles up to $10 \mathrm{~mm}$. 


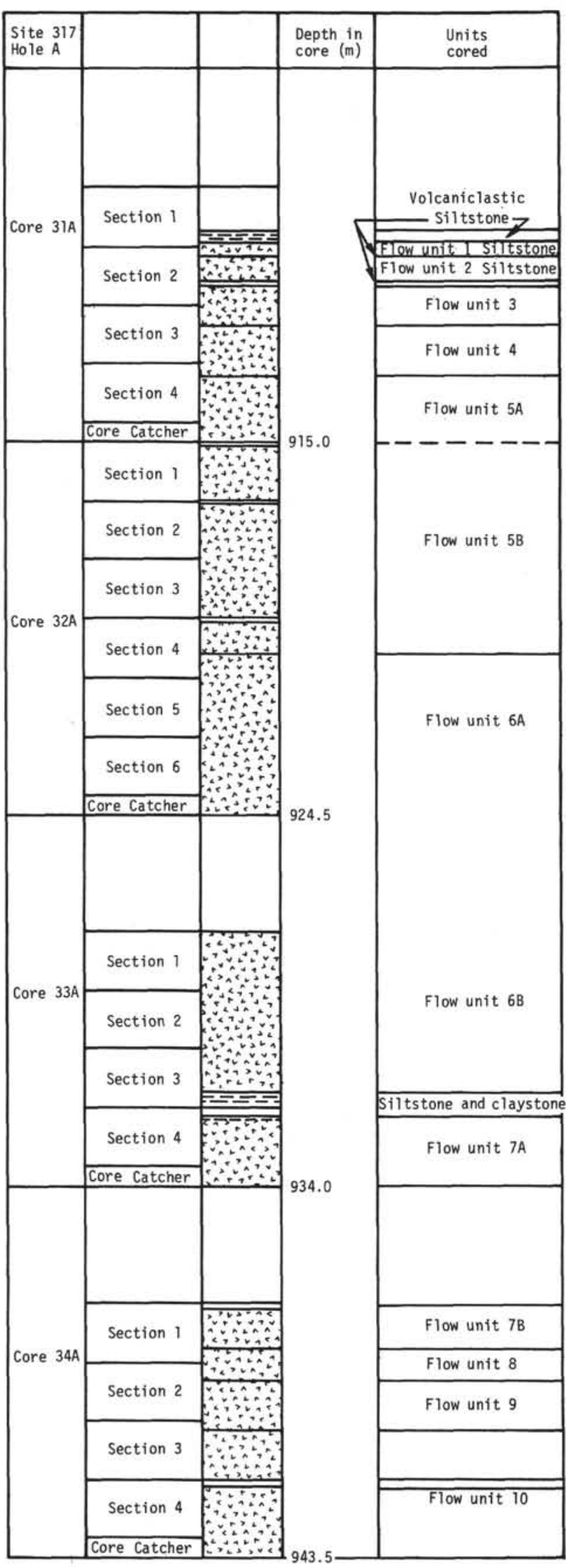

Figure 3. Recovery of cored intervals from the deepest part of Hole $317 \mathrm{~A}$. above. Whole-rock analyses of Flow Unit 5A (Core $33 \mathrm{~A}$ ) indicate that (in order of abundance) montmorillonite, plagioclase, magnetite, and ilmenite are present, but pyroxene could definitely be identified from only one sample where it is slightly more abundant than magnetite and ilmenite. Vesicle fillings are mainly composed of calcite; however, pyrite was identified from one vesicle. Finally, Flow Unit 6 (Core 34A) contains montmorillonite, plagioclase, pyroxene, magnetite, and ilmenite (whole-rock analyses), and montmorillonite and calcite are present as vesicle fillings. In addition, a heavy mineral separation performed on one of the samples (315A-34-1, 99-101 cm) revealed the presence of a small amount of anatase in the heavier fraction of this sample.

The absence or masking of pyroxene in the X-ray analyses of rocks where it is a visible constituent is an artifact of the low intensity of the main pyroxene peaks compared to those of montmorillonite, plagioclase, and calcite. Even X-ray diffraction patterns of pyroxene separates did not show strong peaks.

\section{X-ray Mineralogy, Hole 317A}

For Hole 317A, several X-ray analyses were made of sediment samples above the basalt flows, as well as of the sediments intercalated between basalt flows in Core $33 \mathrm{~A}$. Two samples from Core $29 \mathrm{~A}$ contain only montmorillonite and analcime. In Core $30 \mathrm{~A}$, montmorillonite and analcime are the dominant minerals in the five samples analyzed; however, one sediment sample from the core catcher contains only montmorillonite and plagioclase. Small amounts of hematite and K-feldspar were also noted in several of the samples analyzed. One sample from Core $31 \mathrm{~A}$ contains only montmorillonite, while a second sample from the same core has montmorillonite, heulandite ${ }^{2}$, celadonite, plagioclase, and quartz in approximate order of decreasing abundance. The volcaniclastic sediment between basalt flows in the upper part of the sedimentary section of Core $33 \mathrm{~A}$ consists of plagioclase and pyroxene as the dominant minerals, with smaller amounts of heulandite, celadonite, montmorillonite, quartz, and pyrite. The lower part of this section contains, in approximate order of decreasing abundance, montmorillonite, quartz, calcite, plagioclase, pyroxene, pyrite, and magnetite.

$\mathrm{X}$-ray analyses of the basalt in Core 31A (Flow Units 1 through $5 \mathrm{~A}$ ) indicate that the entire core is uniformly composed of montmorillonite, plagioclase, and pyroxene with traces of magnetite. Vesicle fillings commonly consist of either montmorillonite or calcite, although quartz was found in one vesicle (317A-34-1, 80-82 cm). Flow units $5 \mathrm{~B}$ and $6 \mathrm{~A}$ in Core $32 \mathrm{~A}$ contain the same minerals in order of abundance as the whole-rock and vesicle-filling analyses of Core $31 \mathrm{~A}$; however, no quartz vesicle fillings were noted. About half of the analyses of Core 33A (Flow Units 6B and 7A) show plagioclase as the predominant mineral, while the other half show montmorillonite as the major constituent. The abundance of pyroxene is about the same as in Cores 31A

\footnotetext{
2Distinguished from clinoptilolite by the method of Mumpton (1960) and Murata and Whitely (1973).
} 


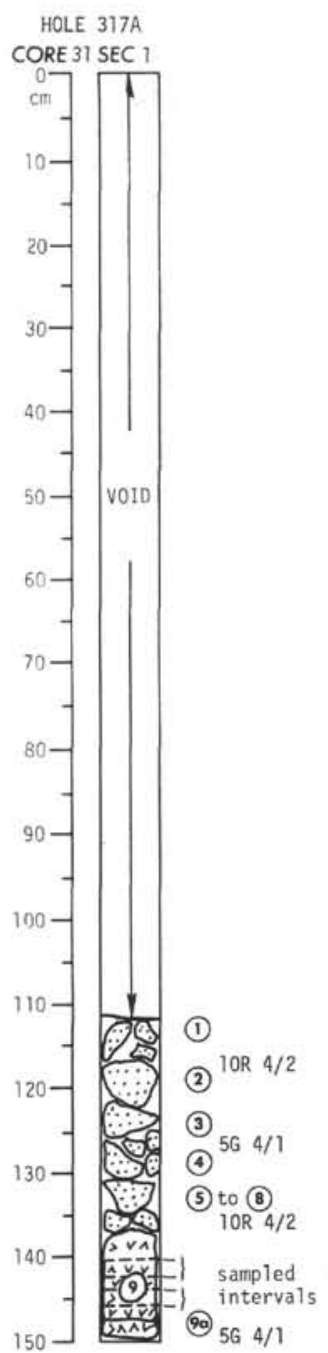

Figure 4. Visual core description of basaltic rocks and associated sedimentary rocks of Hole 317A. Sampled intervals below sections are core-catcher samples.

and $32 \mathrm{~A}$, but magnetite could be identified in only two samples. Vesicle fillings are the same as those of Core $32 \mathrm{~A}$. In Core 34A (Flow Units 7B, 9, and 10), montmorillonite is the dominant mineral, followed by plagioclase and pyroxene. Magnetite was identified in three samples and heulandite in one sample (317A-34-3, 115$117 \mathrm{~cm}$ ). In addition to montmorillonite and calcite vesicle fillings, celadonite fills some of the vesicles in the interval $34-2,84-86 \mathrm{~cm}$ to $34-4,62-64 \mathrm{~cm}$ and is also present in three of the whole-rock analyses from this interval. Again, pyroxene appeared to the suppressed in the diffraction patterns, and, for most samples was visible optically in greater abundance than was indicated by $\mathrm{X}$ ray analysis.

\section{Petrography, Hole 315A}

Petrographic data for the sampled basalts of Hole 315A are given in Table 3. Modes of the rocks are given as percentages of phenocrysts and microphenocrysts, percentages of vesicles, and percentages of groundmass. No attempt was made to point count minerals and

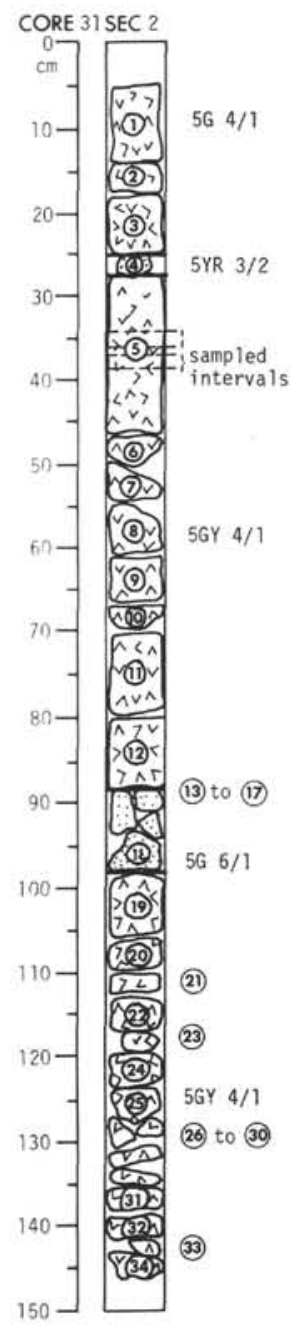

5-25 cm Appears identical to basalt of Core 31 Section 1, 135-150.

$25 \mathrm{~cm}$ Contact between Flow unit 1 and siltstone.

25-27 cm Grayish brown (5YR 3/2) siltstone. More indurated than usual. Probably separates flow units, but part of section may be missing. Neither basalt above or below show chill effects.

$27 \mathrm{~cm}$ Contact between siltstone and flow unit 2.

$27-88 \mathrm{~cm}$ Flow unit 2. Basalt; dark greenishgray; altered; coarsely and abundantly vuggy; moderately abundant microphenocrysts of augite; diabasic. Dark greenish gray ( 5 GY $4 / 7)$ vesicular to vuggy $(2 \times 4 \mathrm{~mm}$ average). Vesicles $20 \%$ increasing from $2 \times 4 \mathrm{~mm}$ near top to $4 \times 8 \mathrm{~m}$ at base. At top completely filled of greenish-black $(5 \mathrm{G} 2 / 1)$ to greenish-gray $(5 G 4 / 1)$ clay minerals, gradually open downward until only vesicle walls are coated with this material. Much like basalt above, but contains much more abundant tiny (.3-.5) microphenocrysts of pyroxene. Groundmass a little coarser, seems to contain less altered glass.

$88 \mathrm{~cm}$ contact between Flow unit 2 and siltstone. $88-97 \mathrm{~cm}$ Greenish gray (5G 6/1) to grayish blue-green $(5 B G 5 / 2)$ siltstone. More indurated than usual. Separates flow units but part of section probably missing. Basalt on either side different but do not show chilled contacts.

$97 \mathrm{~cm}$ Contact between siltstone and Flow unit 3 .

97-146 cm Flow unit 3. Basalt; dark greenishgray; al tered; moderately vesicular and vuggy; very abundant microphenocrysts of augite; intersertal. Dark greenish-gray (5) 3 . $x$. $x$. $x 10$ m. . Rather evenly dispersed through this section. Vesicles lined with greenish-black $(5 \mathrm{G} 6 / 6)$. A very few filled inside greenish black rim with coarse calcite. Appears t contain very abundant pyroxene $(2.5 \mathrm{~mm}$ ) microphenocrysts. Groundmass very fine, appears intersertal.

Figure 4. (Continued).

alteration products of the groundmass, although the extent of alteration is described for each sample. As described in Figure 2 and Table 3, all flow units are similar but texturally distinct. Flow Unit 1 contains less than $1 \%$ iddingsite, presumed to have formerly been olivine; otherwise all flow units are barren of olivine. Flow Units 1 and 2 contain rather abundant microphenocrysts of plagioclase and augite ${ }^{3}$ except near their chilled margins, and while Flow Units 3 to 6 are described as aphyric, plagioclase and augite of about the same composition are only slightly smaller than $0.5 \mathrm{~mm}$. All flow units are vesicular, and the vesicles are small, ranging from 0.1 to $2.0 \mathrm{~mm}$ in size, but averaging about $0.5 \mathrm{~mm}$ in most flow units. Vesicles are also moderately sparse, ranging from 1.5 to $9.0 \%$, and averaging only about $5 \%$ of the rocks. The amount of former groundmass glass ranges from abundant to sparse, but all flow units contain some. All flow units contain magnetite and ilmenite, separately in some flow units and as complex intergrowths in others. No sample examined contained

3Strictly speaking, the "augite" of this section and of Table 3 is salite. 


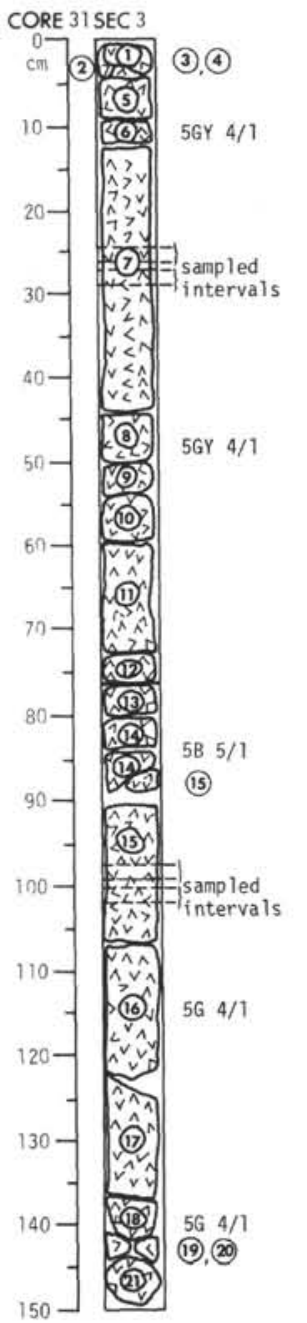

0-10 cm Basalt appears to be the same flow unit as that in Section 2, 97-150 cm.

10-46 cm Basalt, same as above, but vesicles sparser $(<10 \%)$, smaller (average $1 \times 2 \mathrm{~mm}$ )
groundmass coarser, more diabasic, abundant microphenocrysts continu. Sulfide aminerals 25-30 cm appear to be chalcopyrite.

46-77 cm Basalt much like that at base of Section 2, but vesicles less abundant. coarser. Average $4 \times 5 \mathrm{~mm}$ but range up to gas trails $10 \times 25 \mathrm{~mm}$. All lined by blackishgray material, $50 \%$ filled with coarse calcite.

$77 \mathrm{~cm}$ Marked change in color, texture, probably contact, but a little of the contact section may be missing.

$77-150 \mathrm{~cm}$ flow unit 4. Basalt, bluish-gray at top, dark greenish-gray at base; fine and moderately abundant vesicles and vugs; altered; sparse augite phenocrysts; diabasic to intersertal.

$77-92 \mathrm{~cm}$ Basalt, vesicular top of Flow unit 4. Medium bluish-gray (5B 5/1). Vesicles $40 \%$ of rock, average $4 \times 5 \mathrm{~mm}$, but range up to $10-20 \mathrm{~cm}$. Glassy, altered. Vesicles partly filled with blue-green material, partly with calcite.

92-142 cm Basalt, vesicular; vesicles average $1 \times 2 \mathrm{~mm}$, but occasionally very large, some vertical vesicle trails $5 \times 20 \mathrm{~mm}$. Fillings are as in top of unit. Contains $5 \%$ microphenocrysts as pyroxene. Color dark greenishgray $(5 G 4 / 1)$. Central part flow unit 4.

$142-150 \mathrm{~cm}$ Basalt, vesicular base of Flow unit 4. Very much like top of unit, except in color.

Figure 4. (Continued).

chromite. Chalcopyrite, believed to be primary, is very sparsely present, and although pyrrhotite was looked for, it was not seen. All the basalts are altered, but the extent of alteration is quite variable. All intersertal material believed to have formerly been glass is altered to brown montmorillonite, except in the case of Flow Unit 1 where some green montmorillonite replaces either glass or brown montmorillonite. All vesicles are partially to completely filled with alteration products. Almost without exception, brown montmorillonite lines vesicle walls, whereas the centers of the vesicles, where filled, consist of green montmorillonite, and less commonly, calcite or pyrite. A few pyrite and brown montmorillonite veins were observed, and, in a few samples, ilmenite is partially altered to anatase. For each rock thin-sectioned, a second uncovered section was routinely stained with potassium cobaltinitrite (Laniz et al., 1964) for potassium feldspar, but none was found, nor was any present in the X-ray diffraction patterns (Table 3). A third section of each sample was routinely stained for nepheline (Shand, 1939), but again none was observed, and chemical data below suggest that none was present prior to alteration. No celadonite or clinoptilolite were found either optically or by X-ray diffraction.

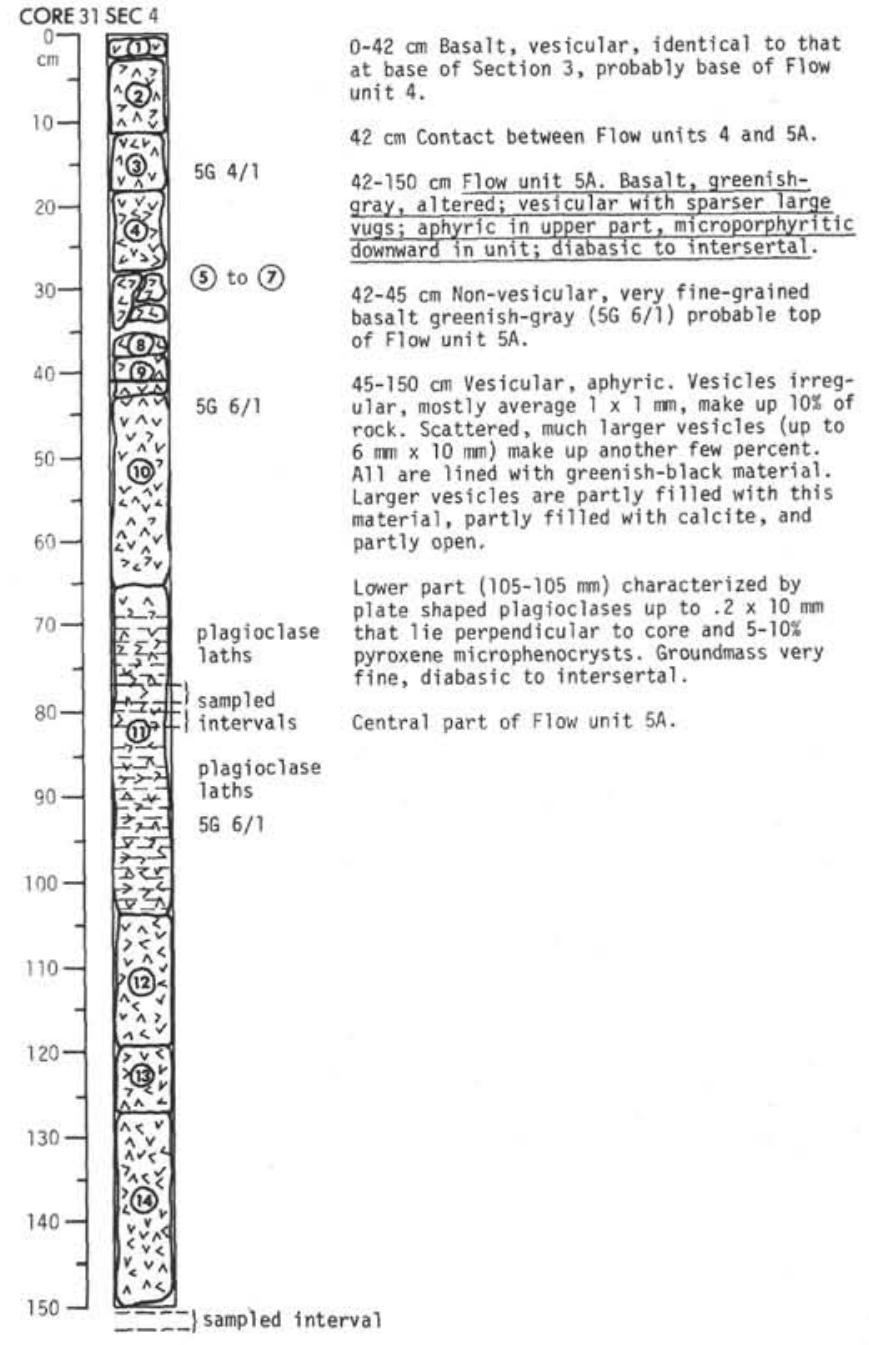

Figure 4. (Continued).

Although the rocks are described as moderately to heavily altered, few of the primary minerals-augite, plagioclase, magnetite, or ilmenite-are altered in most rocks examined. Alteration was confined principally to in situ alteration of original glass to montmorillonite, and to the vesicle-filling minerals described above. The textures of the rocks are therefore quite well preserved (Plate 1).

The preservation of textures has permitted the rather detailed descriptions given in Table 3. Minor textural variations at the sampled intervals confirm the identification of the flow units of Figure 2.

\section{Petrography, Hole 317A}

Petrographic data for Hole 317A are given in Table 4. Modes for phenocrysts, vesicles, and groundmass are given as in Table 3. As described in Figure 4 and Table 4 , all 10 flow units are similar but texturally distinct. No sample examined contains olivine. If olivine were ever present in these rocks, it must have occurred as microlites in the altered groundmass of those rocks that contained original glass. Flow Units 1-5 contain small amounts of microphenocrysts of plagioclase, augite, and a pyroxene with low birefringence and a $2 \mathrm{~V}$ of about 


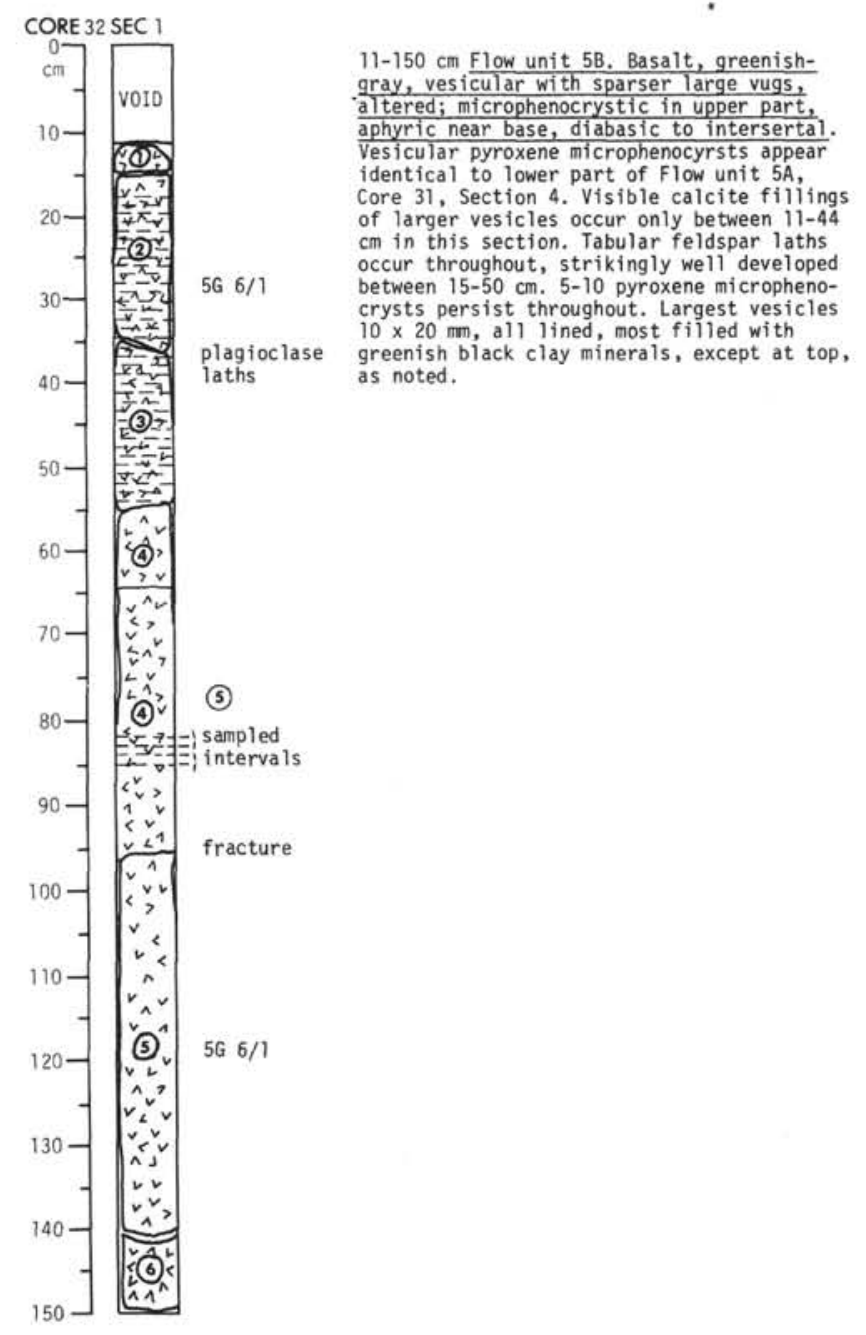

Figure 4. (Continued).

$20^{\circ}$. This is referred to a Ca-poor augite in Table 4, although subsequent probe analyses suggest it is best described as low-calcium augite and ferroaugite. Flow Units 9 and 10 contain small $(1.5 \mathrm{~mm})$ glomeroporphyritic clots of plagioclase and pyroxene that are not uncommon in tholeiitic basalts (Dalrymple et al., 1974). The remainder of the flows are technically aphyric, although both pyroxenes and plagioclase are commonly only slightly less than $0.5 \mathrm{~mm}$ in grain size. Most of the flow units have diabasic to intersertal textures, although Flow Unit 7 is perhaps better described as intergranular-intersertal, and Flow Unit 10 is a vitrophyre. All flow units contain both augite and a low-calcium pyroxene. All flow units are vesicular, and the vesicles or vugs are extremely large (some are as large as $20 \mathrm{~mm}$, and in most flow units they average $5.0-6.0 \mathrm{~mm}$ ). Vesicles are also extremely abundant ranging from $5 \%$ to $30 \%$ of the rocks, and averaging about $10 \%$. The amount of altered groundmass glass ranges from abundant to sparse, but all flow units contain some. All units contain small amounts of magnetite and ilmenite, in some cases as discrete grains and in some cases as complex intergrowths. No chromite was observed in any sample. Chalcopyrite blebs are more common than in

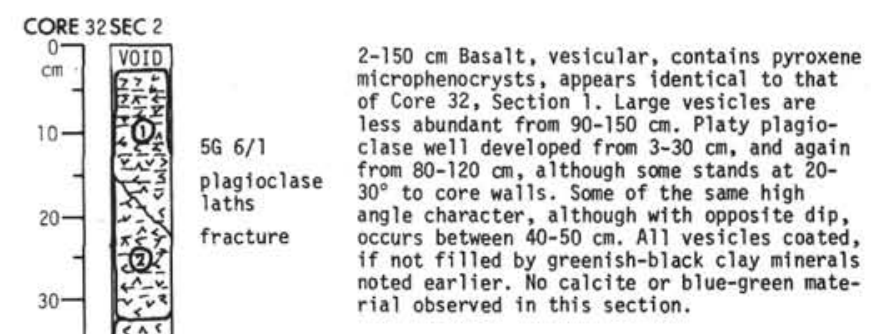

sampled

intervats

plagioc lase
laths

$56 / 1$

rial observed in this section.

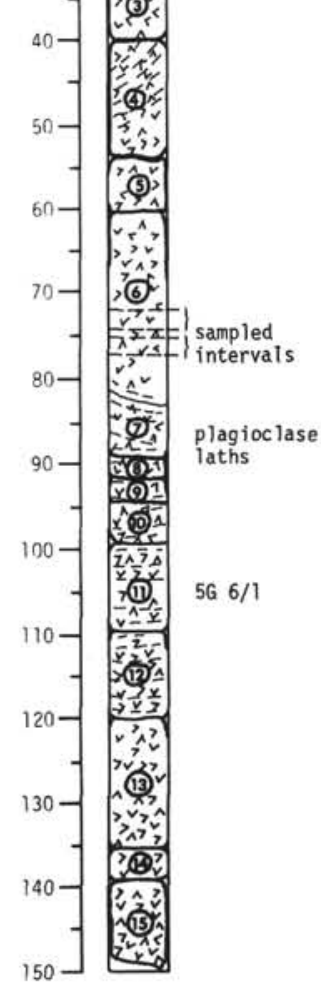

Figure 4. (Continued).

the basalts of Hole 315A, and, in most cases, they are intergrown with pyrrhotite. All the basalts of Hole 317A are altered, but as a whole, they are a good deal fresher than those of Hole 315A in spite of their greater age. All original glass is altered to brown montmorillonite, except in Flow Units 9 and 10, where small amounts of celadonite occur. All vesicles are partially filled with alteration products. Almost without exception, brown montmorillonite coats the outer vesicle walls, and the inner parts of the vesicle walls, if filled, are occupied by green montmorillonite, or, far less commonly, calcite, very minor amounts of quartz, and in one vesicle of Flow Unit 10, celadonite and heulandite. No pyrite was observed either optically or in X-ray diffraction patterns. As with the basalts of Hole $315 \mathrm{~A}$, stained sections and X-ray data revealed no trace of potassium feldspar or nepheline.

Although the basalts of Hole $317 \mathrm{~A}$ are described as somewhat to heavily altered, the extent of alteration is largely a function of the amount of original glass present and the extent to which vesicles are filled. The textures of the rocks are perfectly preserved (Plate 2).

The megascopic identification of flow units of Figure 4 is confirmed by minor variations in groundmass tex- 


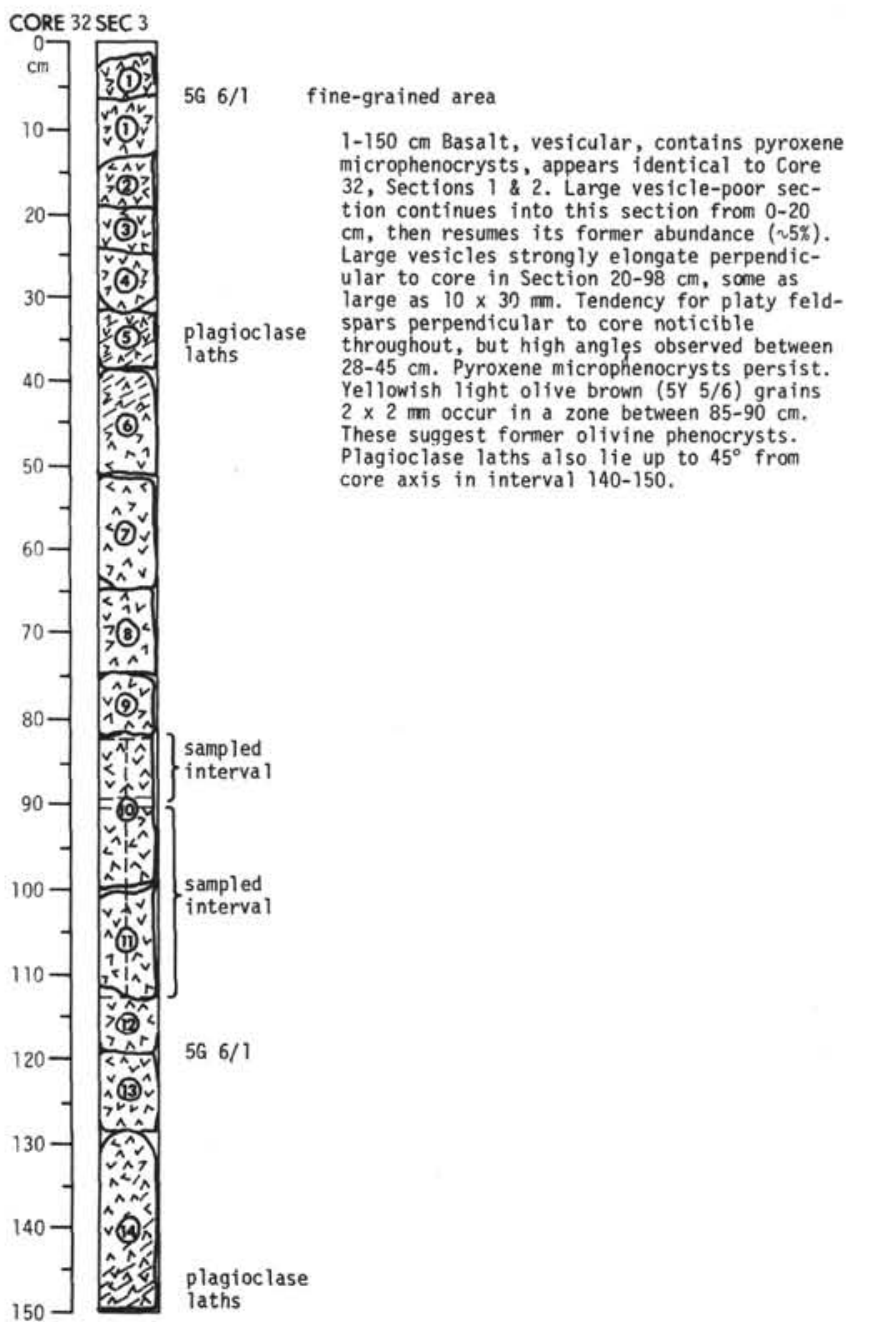

Figure 4. (Continued

tures and by variations in chemical composition noted below. The textures and mineralogy of these rocks appear identical to those of oceanic ridge basalts recovered from DSDP Legs 6, 7, 16, 17, 18, 19, 30, and 32 in the Pacific Basin, except for vesicle size. Moberly and Heath (1971) reported amygdules in the basalt at Site 61 that range in size from 5 to $20 \mathrm{~mm}$, but, for the most part, basalts with abyssal characteristics are dense (Stoeser, in press) to finely vesicular (Bass et al., 1973). The size and abundance of vesicles and vugs in the $317 \mathrm{~A}$ basalts seem highly unusual (Plate 3). Moore (1965) showed that vesicles in the pillowed rims of Hawaiian tholeiites decrease in both size and abundance with increasing water depth. Aumento (1971) was unable to find any such variation in dredged abyssal basalts from the Atlantic. This discrepancy may stem from the fact that Moore (1965) confined his study to pillow skins, whereas Aumento (1971) studied pillow interiors as well. Nevertheless, Aumento showed that of hundreds of Atlantic basalts collected at water depths between 1000 and 3500 meters, none contain circular vesicles with average sizes larger than $3 \mathrm{~mm}$, although he omitted

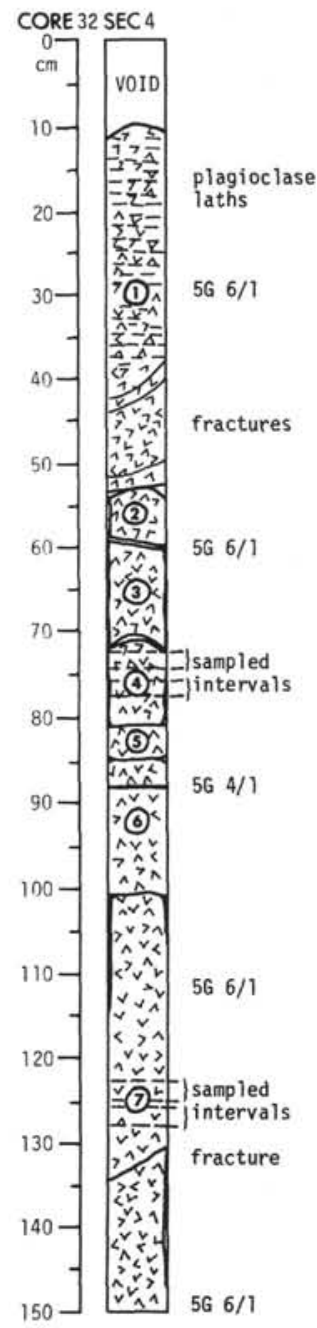

$10-98 \mathrm{~cm}$ Basalt, vesicular, contains pyroxene microphenocrysts. Appears to be identical to Core $321-3$. Vesicles less strongly aligned. Plagioclase laths aligned perpendicular to core at 10-40 cm. Below $40 \mathrm{~cm}$ becomes finer grained, and appears to contain more altered intersertal glass. Vesicles become somewhat $5 \times 20$ vesicle occurs, perpendicular core axis. Fractures at $40-50 \mathrm{~cm}$. Vesicle tining and filling stil only greenish-black clay minerals. No calcite or blue-green fillings observed.

$89 \mathrm{~cm}$ Contact between Flow units $5 \mathrm{~B}$ and $6 \mathrm{~A}$.

89-150 cm Flow unit 6A. Basalt; greenishgray; altered; finely vesicular, with only a few large vugs near top; aphyric; diabasic to intersertal. Vesicular, aphyric, greenishgray (5G 6/1); vesicles even-sized except near contact. At top, a few large vesicles, $5 \times 10$ cm are nearly parallel to core axis. Vesicles lined with greenish-black clay minerals (5GY $2 / 1)$, generally filled, though washed out on core surfaces. Feldspars stubby, lath-shaped. Groundmass texture appears to be diabasic to intersertal. Less glass, perhaps, than Flow intersertal. Less glass, perhaps, than flow unit 5 , but it also appears to be altered. racture at $130-135 \mathrm{~cm}$, visibly al tered to tains some calcite.

Figure 4. (Continued).

"larger, lensoid vesicles of dubious origin" (op. cit., p. 1316) from his study. Earlier, more detailed descriptions of these "larger, lensoid vesicles" (Aumento, 1968) show them to be large tabular vugs in rocks that also contain smaller vesicles. All in all, these larger cavities bear little resemblance to the coarse and abundant vesicles of the basalts of Hole 317A. Moore and Schilling (1973), again measuring only the outer $1-\mathrm{cm}$ rind of pillows at progressively shallower water depths up the Reykjanes Ridge, show a striking correlation between volume percent vesicles and water depth. At water depths of 1000 meters, their samples contain about $5 \%$ vesicles; at 700 meters $10 \%$; at 500 meters, $20 \%$; and at 200 meters, $30 \%$. Only two samples of 7.8 contain $30 \%$ vesicles at water depths greater than 400 meters. Although these data may not be directly comparable to those for the basalts of Hole $317 \mathrm{~A}$, it seems reasonable to conclude that they were erupted in relatively shallow water, or that they contained unusually large amounts of volatile constituents. Vesicles in the basalts of Hole 315A, on the other hand, are of a size and volume appropriate to water depths of 1000-3000 meters. 


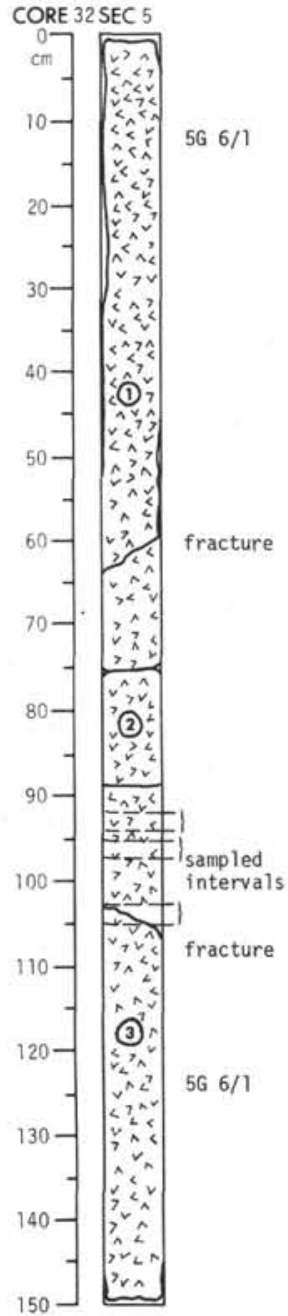

Figure 4. (Continued).

\section{CHEMICAL COMPOSITION OF THE BASALTS FROM HOLES 315A AND 317A}

\section{Major Elements}

One sample from Hole 315A (32-2, 96-105 cm) and one sample from Hole $317 \mathrm{~A}(32-3,100-111.5 \mathrm{~cm})$ were analyzed for major elements by conventional wet chemical methods (Peck, 1964; see Tables 5 and 6). Thirty other analyses for major elements shown in Tables 5 and 6 were obtained by a combination of analytical techniques. X-ray fluorescence techniques were employed for the determination of $\mathrm{SiO}_{2}, \mathrm{Al}_{2} \mathrm{O}_{3}, \mathrm{Fe}_{2} \mathrm{O}_{3}$, $\mathrm{MgO}, \mathrm{CaO}, \mathrm{K}_{2} \mathrm{O}, \mathrm{TiO}_{2}, \mathrm{P}_{2} \mathrm{O}_{5}$, and $\mathrm{MnO}$ (Fabbi, 1972); $\mathrm{Cl}$ (Fabbi and Espos, 1972a); $\mathrm{BaO}$ and $\mathrm{SrO}$ (Fabbi, 1971); total S as S (Fabbi and Moore, 1970); and $\mathrm{Rb}_{2} \mathrm{O}$ (Fabbi and Espos, 1972b). Classical chemical techniques were used to determined $\mathrm{H}_{2} \mathrm{O}^{+}, \mathrm{H}_{2} \mathrm{O}^{-}$, and $\mathrm{FeO}$. $\mathrm{Na}_{2} \mathrm{O}$ was determined by flame photometry because loss of detector resolution during X-ray fluorescence (XRF) analysis affected the determination of $\mathrm{Na}_{2} \mathrm{O}$. Comparative $\mathrm{Na}_{2} \mathrm{O}$ values (Table 7) illustrate differences in accuracy resulting from loss of detector resolution, accuracy obtained with a stable high-resolution detector

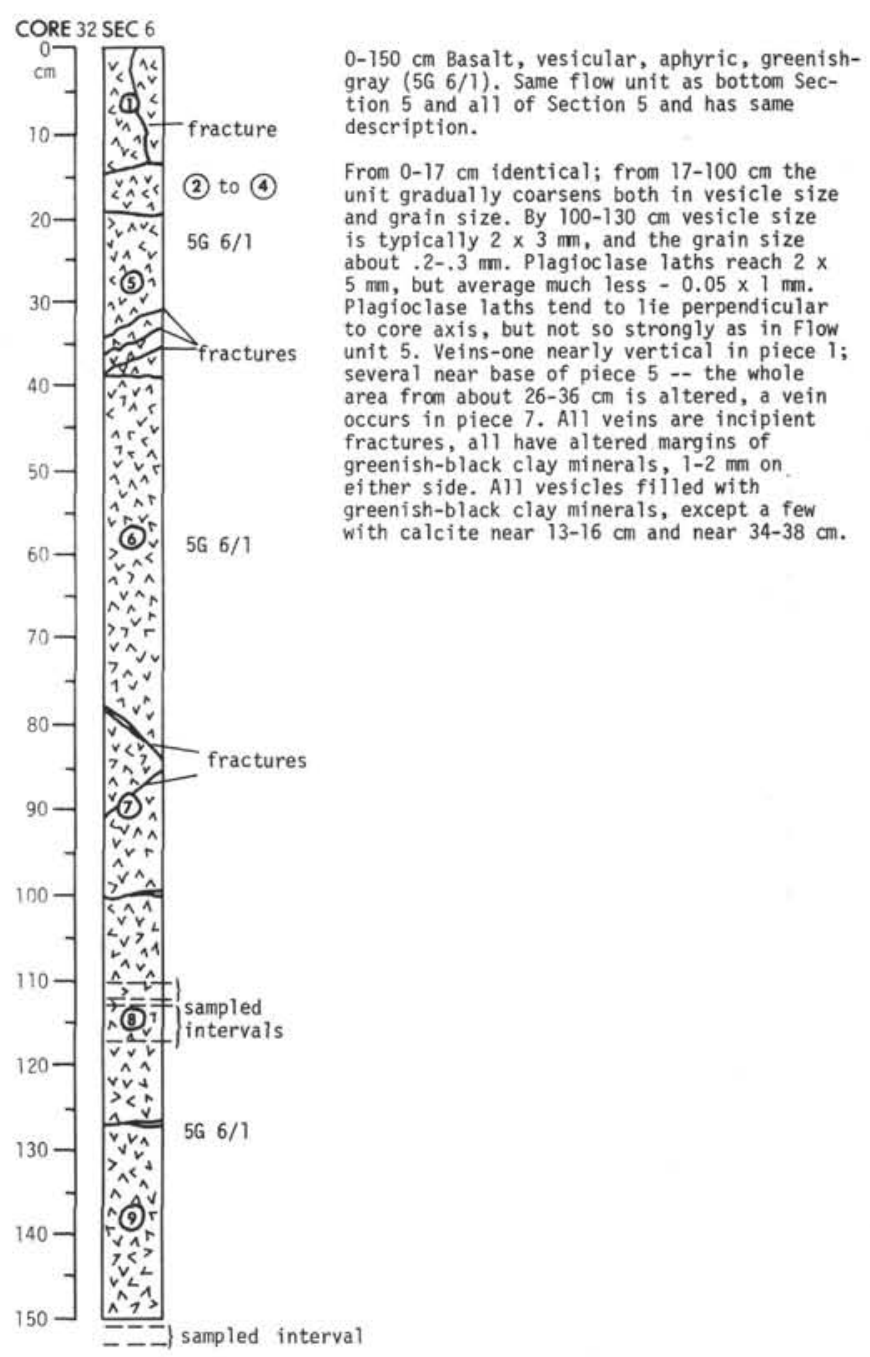

Figure 4. (Continued).

(Fabbi, 1973), and flame photometric results. There is generally good agreement for the $\mathrm{Na}_{2} \mathrm{O}$ values that are within the limits of precision of the two techniques (XRF $\pm 7 \%$ and flame photometer $\pm 2 \%$ ) and the associated sampling errors. Errors caused by the lowresolution detector increase with higher concentrations of $\mathrm{Na}_{2} \mathrm{O}$.

Two duplicate analyses determined by both wetchemical methods and X-ray fluorescence were made for each hole (Samples 315A-32-2, 96-105 cm and 317A-32$3,100-111.5 \mathrm{~cm}$ ). Results in Tables 5 and 6 show the analyses to be within precision limits of the XRF method, except for differences in $\mathrm{H}_{2} \mathrm{O}^{+}$and $\mathrm{H}_{2} \mathrm{O}^{-}$, although the total water in the samples is nearly identical. In general, the duplicate analyses differ by less than $0.3 \%$ for major constituents, and $0.03 \%$ for less abundant constituents.

It is clear from the major-element data that the basalts are considerably altered. The total water content of basalts from Hole $315 \mathrm{~A}$ ranges from $5.98 \%$ to $7.88 \%$ and averages $6.85 \%$. More than half of the iron in these samples is oxidized. The basalts of Hole 317A are 


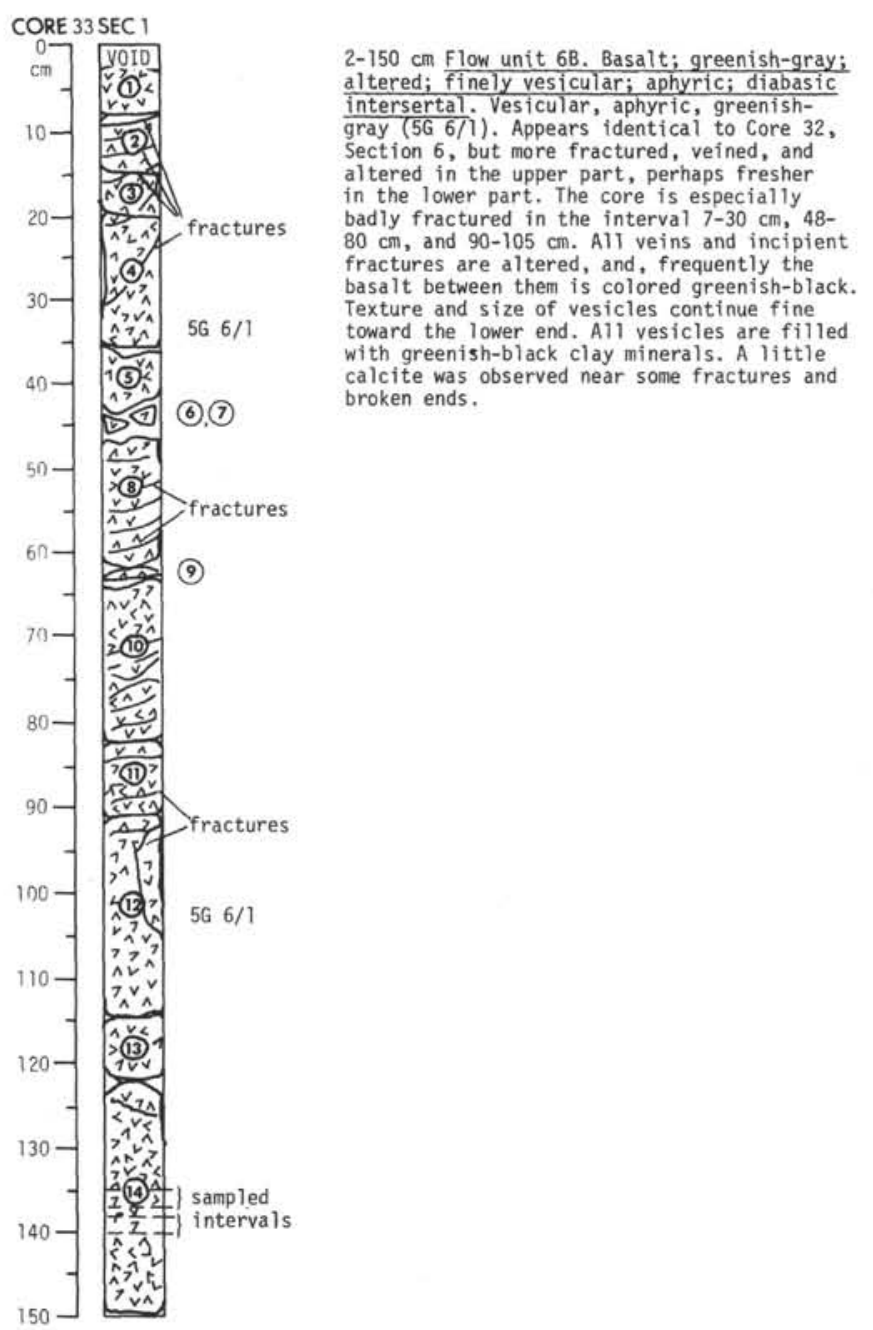

Figure 4. (Continued).

somewhat fresher; total water content ranges from $2.69 \%$ to $7.00 \%$ and averages $4.00 \%$; less than half the iron is oxidized.

\section{Minor Elements}

Complete spectrographic analysis was performed on 30 basalt samples utilizing the semiquantitative six-step method (Myers et al., 1960). The data supplemented our information in regard to the petrologic studies using major- and minor-element correlations. Good agreement was observed in most minor elements when compared with values obtained by $\mathrm{X}$-ray fluorescence.

$\mathrm{Cr}, \mathrm{Nb}, \mathrm{Ni}, \mathrm{Zr}, \mathrm{Y}$, and $\mathrm{V}$ (Tables 8 and 9) were also quantitatively determined by the powder D-C arc technique (Bastron et al., 1960). Interlaboratory synthetic standards and chemically analyzed rock standards were used to draw our analytical curves and to read off our concentration values. Because of the basic nature of the samples, analytical curves generated by the W-1 (diabase) and BDR (Columbia River Basalt) standard rock dilutions were favored over the curves obtained by the use of synthetic interlaboratory standards. Therefore, by using standards of chemical composition similar to that of the samples, matrix effects were minimized that

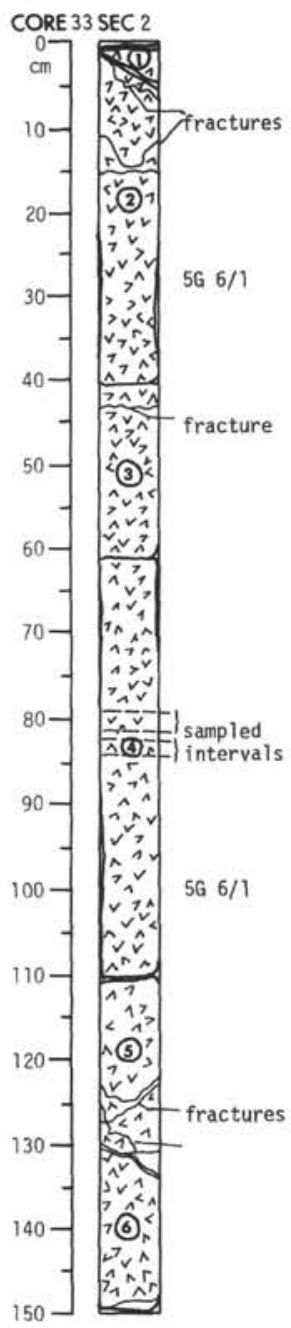

$1-150 \mathrm{~cm}$ Basalt, vesicular, aphyric, greenishgray $(5 \mathrm{G} 6 / 1)$. Almost identical to core 32 , Section 5 , perhaps has finer vesicles and is finer grained than Core 32, Section 6, Core 33, Section 1, although almost surely part of the same flow unit. Small fractures $1-15 \mathrm{~cm}$, $42 \mathrm{~cm}, 122-135 \mathrm{~cm}$, some al teration but not

Figure 4. (Continued).

otherwise might have adversely affected the overall accuracy of our analysis.

A direct comparison of the values obtained by both methods indicates that good agreement exists among all elements analyzed, with zirconium $(\mathrm{Zr})$ having the poorest agreement because of its refractory nature in the arc. An overall accuracy of $\pm 15 \%$ for all elements was maintained. $\mathrm{Ce}, \mathrm{Co}, \mathrm{Cr}, \mathrm{Cs}, \mathrm{Eu}, \mathrm{Fe}, \mathrm{Gd}, \mathrm{Hf}, \mathrm{Sc}, \mathrm{Ta}, \mathrm{Tb}, \mathrm{Th}$, $\mathrm{Yb}, \mathrm{Zn}$, and $\mathrm{Zr}$ were determined by fluorimetric analysis (Flanagan et al., in press) and $U$ by radioactivation techniques (Tables 10 and 11). It is apparent from inspection of Tables 5, 6, 8, 9, 10, and 11 that although the minorelement contents of basalts in Holes 315A and 317A show little internal variation, abundances of most elements in the rocks from the two holes are significantly different. For example. $\mathrm{Ba}, \mathrm{Sr}, \mathrm{Nb}, \mathrm{P}, \mathrm{Ti}, \mathrm{V}, \mathrm{Y}$, and $\mathrm{Zr}$ and much lower in basalts of Hole 317A than in those of $315 \mathrm{~A}$, whereas $\mathrm{Cr}, \mathrm{Ni}$, and $\mathrm{Sc}$ are higher.

\section{Mineral Analyses}

Plagioclase and pyroxene analyses for three selected flow units of Holes 315A and 317A are given in Table 12. Compositions of plagioclase microphenocrysts in Hole $315 \mathrm{~A}$ are nearly constant with An values of 61-62; 


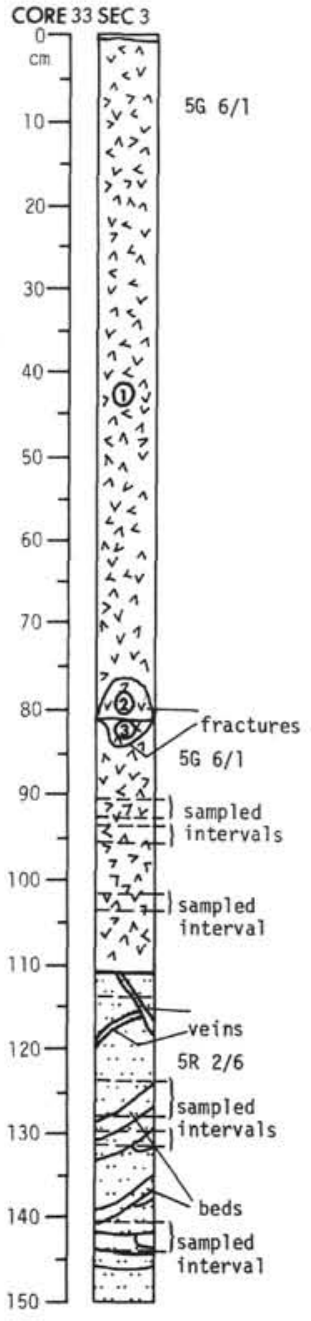

Figure 4. (Continued).

one groundmass plagioclase analyzed also has a composition of $\mathrm{An}_{61}$. Three groundmass plagioclases from Hole 317A have a range in composition of $\mathrm{An}_{58-69}$. These values are lower than those given by the $\mathbf{X}$-ray method (see Tables 3 and 4), but energy-dispersive methods were used for determining microprobe values of $\mathrm{CaO}$ and $\mathrm{K}_{2} \mathrm{O}$ in the plagioclases, and $\mathrm{K}_{2} \mathrm{O}$ values, while significant with respect to one another, may be uniformly high. In fact, separated plagioclase whose $\mathrm{K}_{2} \mathrm{O}$ content was determined by isotope dilution for $315 \mathrm{~A}-32-2,83.5-91 \mathrm{~cm}$ and $317 \mathrm{~A}-32-3,84-85 \mathrm{~cm}$ and $86-$ $88 \mathrm{~cm}$ give values $0.16 \%-0.18 \%$ and $0.09 \%-0.10 \%$, respectively (Lanphere and Dalyrymple, this volume). In addition, the IV coordinated ions in all the plagioclases are low, probably reflecting the presence of $\mathrm{Fe}_{2} \mathrm{O}_{3}$, which was not determined (see Beeson, 1973).

All of the analyzed pyroxenes of Hole 315A are salites; the two microphenocryst averages are almost identical with $\mathrm{Ca}_{49-50} \mathrm{Mg}_{32} \mathrm{Fe}_{18-19}$, whereas the groundmass pyroxene proved to be somewhat richer in $\mathrm{Fe}$ and poorer in $\mathrm{Ca}$ (Table 12). The pyroxenes of Hole 317A are more variable, but easily separable from those of Hole $315 \mathrm{~A}$ by their lower $\mathrm{Ca}$ content and greater range of $\mathrm{Mg}$ and $\mathrm{Fe}$ contents (see Figure 5). It is apparent that

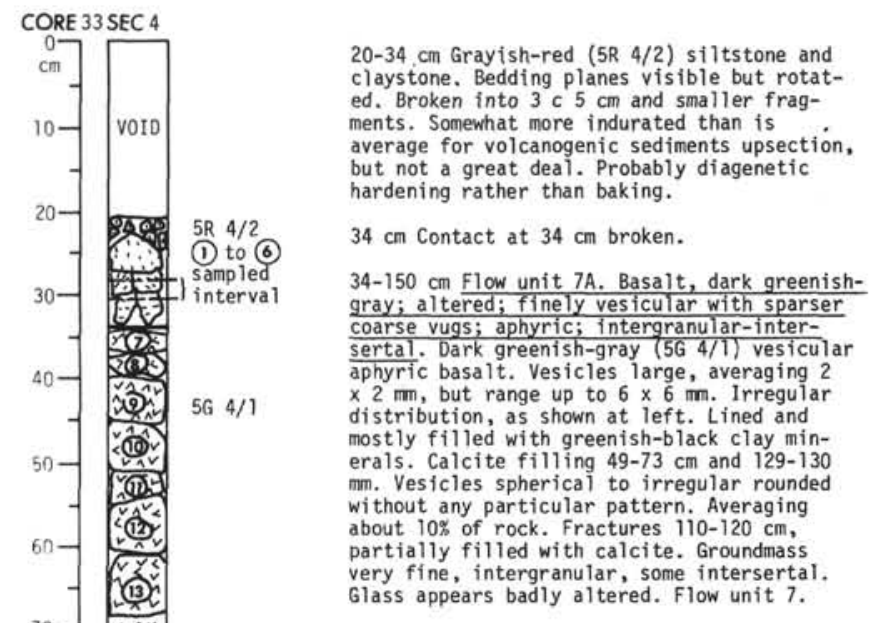

Figure 4. (Continued).

two pyroxenes are present in each flow unit of Hole $317 \mathrm{~A}$ analyzed. It is also apparent that the augites of Flow Unit 2, whether present as microphenocrysts or groundmass minerals, have a rather restricted range composition of $\mathrm{Ca}_{38-40} \mathrm{Mg}_{50-54} \mathrm{Fe}_{8-10}$, whereas one groundmass pyroxene with low birefringence and small $\left(20^{\circ}\right) 2 \mathrm{~V}$ is a calcium-poor augite with ratios of $\mathrm{Ca}_{32.5} \mathrm{Mg}_{53} \mathrm{Fe}_{14.5}$. In Flow Unit $5 \mathrm{~B}$, both microphenocrysts analyzed are characterized by low birefringence and low $2 \mathrm{~V}$ and proved to be calcium-poor ferroaugites, whereas the one groundmass augite analyzed contains more $\mathrm{Ca}$ and much less $\mathrm{Fe}$. In Flow Unit 7B, where three groundmass pyroxenes were analyzed, two are augites with compositions of $\mathrm{Ca}_{37-39} \mathrm{Mg}_{47-52} \mathrm{Fe}_{10-14}$, whereas the other one was a low birefringence and low $2 \mathrm{~V}$ pyroxene with a composition of $\mathrm{Ca}_{25} \mathrm{Mg}_{54} \mathrm{Fe}_{21}$. The wide range and unusual composition of the pyroxenes in Hole $317 \mathrm{~A}$ and their differences in different flow units merit further study.

\section{Dry Reduced Analyses and Norms}

The dry reduced chemical analyses of the basalts of Hole 315A are given in Table 13. These analyses show 


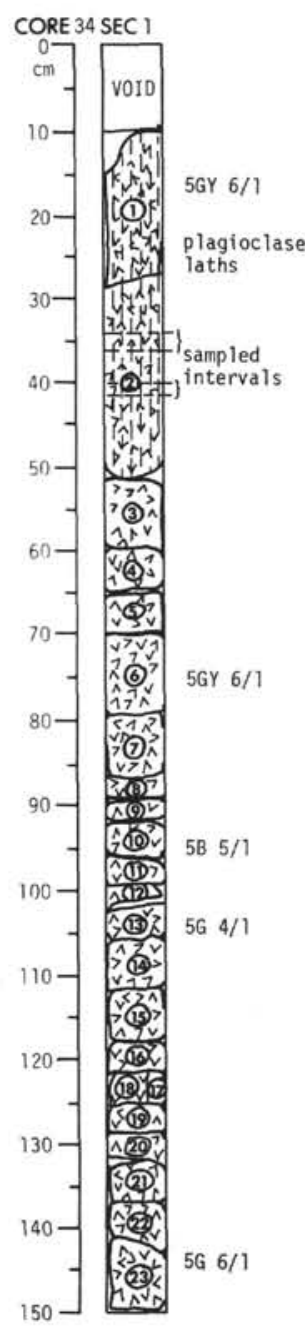

10-90 cm Flow unit 7B. Basalt; greenish-gray; finely vesicular with sparse coarse vugs in upper part; aphyric; intergranular-inter sertal. Basalt, greenish-gray (5GY 6/1) vesicular aphyric basalt. Probably lower part of Flow unit 7A. Vesicles large in upper part -- up to 5-10 mm - some in obliqur trails 50 mm long. Gradually changes downward to irreg ular shaped vesicles averaging 1 min in diameter. Mostly filled with greenish-black clay minerals, but calcite is also fairly abundant. Unit characterized by vertical feldspar laths - as large as $5 \mathrm{~mm} \times 4.0 \mathrm{~mm}$ in upper part. avera downward in size. Some of these are in cal variolitic sheaves. Glass not abundant if resent.

$90 \mathrm{~cm}$ Contact at $90 \mathrm{~cm}$ between Flow units $7 \mathrm{~B}$ and 8 altered.

$90-150 \mathrm{~cm}$ Flow unit 8 , dark greenish-gray; altered; vesicular to coarsely vuggy; plagioclase phenocrysts and glomeroporphyritic clots of pyroxene and plagioclase; diabasic-inter-

90- $110 \mathrm{~cm}$ Medium bluish-gray (5B 5/1) finegrained, heavily altered.

$110-150 \mathrm{~cm}$ Dark greenish-gray (5G 4/1) vesicular, with plagioclase phenocrysts and glomeroporphyritic clots of pyroxene and plagioclase. Vesicles very abundant in this, the upper part of flow unit. Size range $1 \times$ to $10 \times 15$ m averaging $2 \times 3$ m. cles make up $30 \%$ of rock from 118-143 $\mathrm{cm}$ Plagioclase phenocrysts are small, blocky, . crysts make up $25 \%$ of vesicular rock. clots crester $10 \%$ pets by greenish-black clay ininerals, and partly by icrenish black clay minerals, and partiy by (a) clay inerals. Coarse calcite fills vesicles in liter part of vesicular section. Lowest unit $142-150 \mathrm{~cm}$ ) is finer grained, aphyric, and as fewer vesicles.

Figure 4. (Continued).

no quartz or nepheline in their norms, and their totalalkali to $\mathrm{SiO}_{2}$ ratios place them above Macdonald's (1968) line separating alkalic basalts from tholeiites. We consider this line more appropriate for oceanic rocks than Irvine and Baragar's (1971) line. Nevertheless, the norms of these rocks contain from $2.43 \%$ to $9.06 \%$ normative diopside, from $4.43 \%$ to $16.65 \%$ normative hypersthene, and from $15.03 \%$ to $22.35 \%$ normative olivine, where neither olivine nor low-calcium pyroxene was observed in the rocks. Furthermore, normative An values are, in general, less than 50 , whereas feldspar in the rocks has values in the range $\mathrm{An}_{59}$ to $\mathrm{An}_{68}$. In addition, En-Fs ratios are lower than observed in mineral analyses of the pyroxenes (see above). It is possible that in the process of alteration, both $\mathrm{SiO}_{2}$ and $\mathrm{CaO}$ may have been selectively removed, and $\mathrm{Na}_{2} \mathrm{O}$ and $\mathrm{MgO}$ added to the rocks. Their total chemical composition, which will be disucssed further below, is similar to oceanic island, not oceanic ridge lavas, although the problem of whether they are somewhat altered oceanic island tholeiites, mildly alkalic basalts, or transitional between the two remains in some doubt.

The dry reduced analyses from Hole 317A (Table 14) differ considerably from those of Hole $315 \mathrm{~A}$, and their

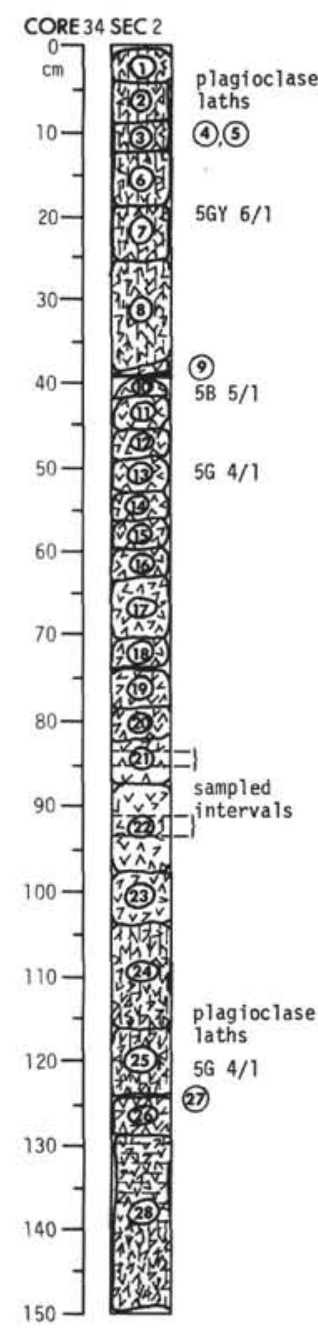
$0-39 \mathrm{~cm}$ Basalt, greenish-gray ( $5 \mathrm{GY} 6 / 1$ ),
vesicular, aphyric, vertical feldspar laths. Appears identical to flow unit at base of Section 1, but contains vertical feldspar laths like those in the lower part of Flow unit 7 .

$39 \mathrm{~cm}$ Contact at $39 \mathrm{~cm}$ between flow units 8 and 9 altered.

39-150 cm Flow unit 9. Basalt greenish-gray; altered; vesicular to very coarsely vuggy; local plagioclase phenocrysts and abundant glomeroporphyritic clots of pyroxene and plagioclase; intersertal-diabasic.

39-44 cm Medium bluish-gray, fine-grained, heavily altered.

44-150 cm Greenish-gray (5G 4/1) vesicular plagioclase phenocrysts and glomeroporphyritic clots. Vesicles very large in central part -clots. $15 \times 15 \times 20$ much 1 ike middle part of Flow unit 8 down to $110 \mathrm{~cm}$. Then becomes gradually finer, like lower part Then becomes gradually finer, like lower par filling uniterial Light bice-green vesicle filling material concentrated near upper contact; calcite in central part.
Figure 4. (Continued).

norms are in better accord with their observed mineralogy. Five of the analyses have $0.05 \%-0.6 \%$ normative quartz; none has normative nepheline. Their normative diopside contents range from $15.2 \%$ to $27.2 \%$, their normative hypersthene contents range from $18.2 \%$ to $27.7 \%$, and their normative olivine contents range from 0 (in five samples) to $11.1 \%$. Furthermore, normative An contents are much more nearly compatible with those observed in the rocks. These rocks contain no modal olivine, and Ca-rich pyroxene generally exceeds Ca-poor pyroxene. It would appear that the dry reduced analyses of basalts of Hole 317A more closely approximate their original compositions even though, in some cases, $\mathrm{SiO}_{2}$ and $\mathrm{CaO}$ may have been lost during alteration, and some $\mathrm{Na}_{2} \mathrm{O}$ and $\mathrm{MgO}$ may have been added.

As a test of this possibility, we plotted $\mathrm{Na}_{2} \mathrm{O}, \mathrm{MgO}$, $\mathrm{CaO}$, and $\mathrm{SiO}_{2}$ against total water content in rocks of both holes in Figure 6. Normally, oxides on this diagram should show increases proportional to their relative abundance in the rocks. This figure failed to confirm that dry reduced $\mathrm{Na}_{2} \mathrm{O}$ was much affected by degree of alteration as evidenced by total water content, unless $\mathrm{Na}_{2} \mathrm{O}$ was added at water levels less than $2.5 \%$. Figure 6 does show clearly, however, that dry reduced 


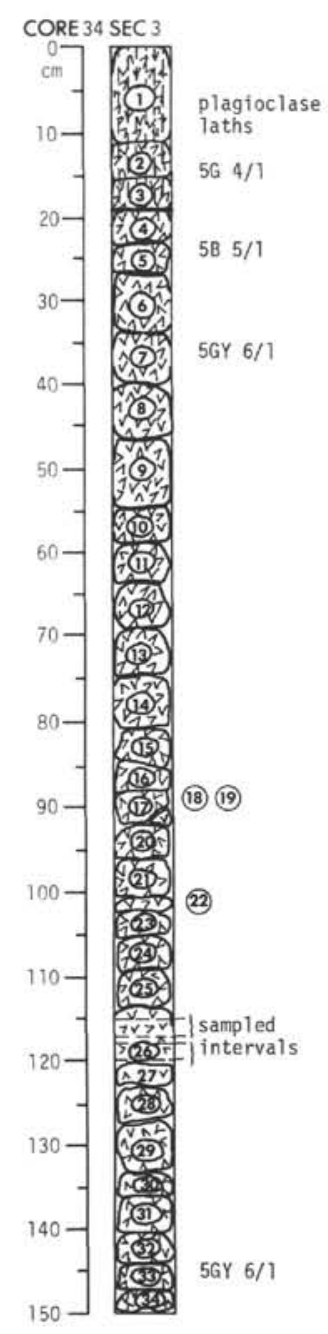

Figure 4. (Continued).

$\mathrm{CaO}$ and $\mathrm{SiO}_{2}$ decrease somewhat irregularly, with increasing water content of the basalts of both holes. Dry reduced $\mathrm{MgO}$ increases, as it should, but more than its relative abundance in the basalts would suggest that it should.

The range and average values of both major and minor elements of basalts from both holes are compared in Table 15. Differences between both ranges and averages show that the basalts from the two holes differ from one another for nearly every oxide or element, except for $\mathrm{CaO}, \mathrm{Co}, \mathrm{Cs}$, and $\mathrm{Rb}$. Considering that the dry-reduced whole-rock analyses are fairly representative of the fresh basalts that once resided at Sites 315 and 317, that the minor-element contents for the most part are representative of original contents in the basalts, and that the mineral analyses are representative of the basalts at both sites, then it is clear that the chemical compositions of the basalts of $317 \mathrm{~A}$ are much like those of other oceanic ridge tholeiites drilled in the Pacific. It seems equally clear that the chemical composition of the basalts from Hole $315 \mathrm{~A}$ are not of that type, but are more nearly comparable to basalts of oceanic islands.

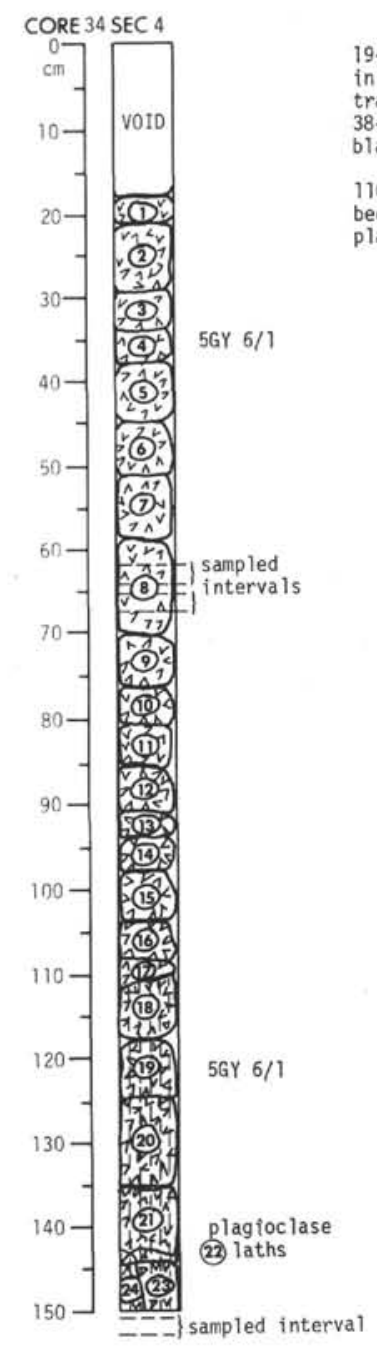

Figure 4. (Continued).

\section{COMPARISONS WITH COMPOSITIONALLY RELATED BASALTS}

\section{Mineral Compositions}

Plagioclase compositions in the basalts of Hole 315A range from $A_{58.9}$ to $A n_{68,5}$, whereas those of the basalts of Hole 317A range from $A n_{580}$ to $A n_{735}$, and average to higher An values. Such ranges of An values have been reported for oceanic island tholeiites and alkalic basalts (Keil et al., 1972) for oceanic ridge tholeiites (Ridley et al., 1974; Stoeser, in press), and although oceanic ridge basalts generally contain more An-rich feldspar, the reported values give little clue as to basaltic type.

Fodor et al. (1975) show salite to be the common pyroxene of Hawaiian alkalic basalts, whereas highcalcium pyroxenes of the Hawaiian tholeiitic suite have $\mathrm{Ca}$ contents of 40 more percent or less. On this criterion the Hole $315 \mathrm{~A}$ pyroxenes are similar to those of alkalic basalts of the oceanic island type. Both Hawaiian tholeiites and oceanic ridge tholeiites commonly contain two pyroxenes, but the Hawaiian ones range between 
TABLE 2

Drilling Summary of the Deepest Cores of Hole 317A

\begin{tabular}{|c|c|c|c|c|}
\hline Core & $\begin{array}{l}\text { Drilled } \\
\text { Interval } \\
(\mathrm{m})\end{array}$ & $\begin{array}{c}\text { Drilling } \\
\text { Rate } \\
(\mathrm{m} / \mathrm{hr})\end{array}$ & $\begin{array}{c}\text { Recovery } \\
\text { (\%) }\end{array}$ & $\begin{array}{l}\text { Flow Unit } \\
\text { Thickness (m) } \\
\text { (see Figure 3) }\end{array}$ \\
\hline $25 \mathrm{~A}-30 \mathrm{~A}$ & 57.0 & $3.2-5.5$ & $63.2-100.0$ & \\
\hline & & & & $\begin{array}{ll}1 & 0.3 \\
2 & 0.65\end{array}$ \\
\hline $31 \mathrm{~A}$ & 9.5 & 11.1 & 50.5 & 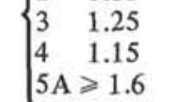 \\
\hline $32 \mathrm{~A}$ & 9.5 & 19.0 & 91.6 & $\left\{\begin{array}{l}5 \mathrm{~B} \geqslant 5.3 \\
6 \mathrm{~A} \geqslant 5.1\end{array}\right.$ \\
\hline $33 \mathrm{~A}$ & 9.5 & 15.0 & 61.1 & $\left\{\begin{array}{l}6 \mathrm{~B} \geqslant 4.1 \\
7 \mathrm{~A} \geqslant 1.7\end{array}\right.$ \\
\hline $34 \mathrm{~A}$ & 9.5 & 14.3 & 58.9 & $\begin{cases}7 \mathrm{~B} \geqslant & 0.8 \\
8 & 1.0 \\
9 & 1.3 \\
10 \geqslant & 3.3\end{cases}$ \\
\hline
\end{tabular}

augite and pigeonite, whereas pyroxenes of oceanic ridge tholeiites more commonly range toward calciumpoor augites and calcium-poor ferroaugites (Fodor et al., 1975; Ridley et al., 1974; Stoeser, in press). Clearly, the pyroxenes of Hole $317 \mathrm{~A}$ are of the oceanic ridge tholeiite type.

\section{Minor Elements}

A number of authors have considered that certain stable (refractory) minor elements preserve their primary concentrations and ratios even in highly altered volcanic rocks, and that these elements are of greater assistance than major elements in identifying basaltic suites in their partially altered parents (Ishikawa, 1968; Kay et al., 1970; Hart and Nalwalk, 1970; Hart, 1971; Schilling, 1971; Matthews, 1971; Pearce and Cann, 1973; Bass et al., 1973; Stoeser, in press; Marshall, in press). One such discriminant plot is that of $\mathrm{P}_{2} \mathrm{O}_{5}$ against $\mathrm{TiO}_{2}$ in weight percent (Figure 7). The fields of Figure 7 are from Bass et al., (1973), but we have plotted Macdonald and Katsura's (1964) average alkalic basalts and tholeiites on the diagram for comparison, and these fall quite satisfactorily into Bass et al.'s (1973) fields. Basalts of Hole $317 \mathrm{~A}$ fall in the lower left corner of the diagram, well into the oceanic ridge tholeiite (ocean ridge basalt) field, and compare well with Stoeser's (in press) values from the Ontong-Java Plateau. The ratios for the basalts of Hole $315 \mathrm{~A}$, on the other hand, straddle the field between Hawaiian tholeiites and true alkalic basalts; the Hole $315 \mathrm{~A}$ rocks are clearly of the oceanic island type, but are much less strongly alkalic than Bass et al.'s (1973) rocks from Site 165, which contain between 6\% and $15 \%$ normative nepheline and approximately twice as much $\mathrm{K}_{2} \mathrm{O}$ as post-erosional basalts of the Honolulu Volcanic series (Jackson and Wright, 1970). These rocks were called hawaiites and mugearites by Bass et al. (1973), but as Natland (this volume) points out, they are better called potassic basanites and nephelinites.

On a $\mathrm{Zr}-\mathrm{Nb}$ plot, the basalts of Hole $317 \mathrm{~A}$ are below the limit of detectability of $\mathrm{Nb}$, but nonetheless, fall safely within the oceanic ridge tholeiite field (Figure 8). Very little is known about the quantitative ratios of $\mathrm{Nb}$ and $\mathrm{Zr}$ in Hawaiian basalts, but such data as are available are given in Figure 8. Unpublished semiquantitative spectrographic data suggest that Hawaiian tholeiites generally have $\mathrm{Nb}$ values detectable at $>10 \mathrm{ppm}$ and $\mathrm{Zr}$ values ranging from 70 to $150 \mathrm{ppm}$, whereas alkalic basalts have $\mathrm{Nb}$ values that range from 10 to $40 \mathrm{ppm}$, and $\mathrm{Zr}$ values that range from 70 to $250 \mathrm{ppm}$. The Hole $315 \mathrm{~A}$ basalts thus appear to fall in the field for Hawaiian alkalic basalt rather than tholeiite ratios.

On a plot of $\mathrm{Zr}$ against $\mathrm{Sr}$ (Figure 9), the basalts of Hole $317 \mathrm{~A}$ again fall within the established oceanic ridge tholeiite (ocean ridge basalt) field, along with Stoeser's Ontong-Java samples. Again the basalts of Hole $315 \mathrm{~A}$ are ambiguous. Their $\mathrm{Zr}$ values are those of Hawaiian alkalic basalts; their $\mathrm{Sr}$ values those of Hawaiian tholeiites. Unless the rocks have lost $\mathrm{Sr}$, or, less likely gained $\mathrm{Zr}$, they plot in a presently unique field.

Pearce and Cann (1973) have devised several diagrams for the minor-element distinction of basaltic subtypes. They generally divide basaltic rocks into four categories, "ocean floor basalts" for which term we use oceanic ridge tholeiites; "low potassium tholeiites" by which they mean tholeiites of island arcs; "within plate basalts" in which they combine both continental and oceanic island type tholeiites and alkalic basalts; and "calc-alkali basalts" by which they mean andesitic rocks of island arcs. One of their discriminant plots is $\mathrm{Ti}$ against $\mathrm{Zr}$ (Figure 10). Ti-Zr ratios of the Hole $317 \mathrm{~A}$ basalts fall in their fields B and C. Stoeser's (in press) Ontong-Java samples fall outside their field B. $\mathrm{Ti}-\mathrm{Zr}$ ratios of the Hole 315A basalts and Bass et al.'s (1973) rocks fall outside any field in the diagram. Another of Pearce and Cann's (1973) plots which purports to discriminate tholeiite from alkalic rocks involves the ratio $\mathrm{Y} / \mathrm{Nb}$ (Figure 11). The basalts from Hole 317A cannot be unequivocally plotted because $\mathrm{Nb}$ was reported as not detected at $15 \mathrm{ppm}$; but could well plot into the tholeiitic field. The basalts from Hole $315 \mathrm{~A}$, however, are plainly transitional on this diagram. Pearce and Cann's (1973) discriminant diagram that involves ratios of $\mathrm{Ti}, \mathrm{Y}$ and $\mathrm{Zr}$ (Figure 12) does not separate the rather different basalts of Holes 315A and 317A.

Our data plotted on Ishikawa's (1968) diagrams (Figures 13a and 13b) also shows little discrimination, although the $315 \mathrm{~A}$ basalts tend to favor alkalic rather than tholeiitic Hawaiian trends. There appears to be considerable scatter among oceanic ridge tholeiites, including the basalts of Hole 317A.

Schillings's (1966) chrondrite-normalized rare-earth patterns for average Hawaiian tholeiite and average Hawaiian alkalic basalt show the characteristic mild enrichment of light rare-earth elements typical of these rocks. The Hole $315 \mathrm{~A}$ basalts show the same type of enrichment, but to a lesser extent (Figure 14a). Figure $14 \mathrm{~b}$ shows the same comparison between the basalts of Hole $317 \mathrm{~A}$ and other oceanic ridge tholeiites. Both have characteristic flat patterns with a slight depletion of light rare-earth elements.

Shih (1974) has suggested that enrichment or depletion in light rare-earth elements can be used to distinguish between basaltic suites, and that the chondritenormalized $\mathrm{Ce} / \mathrm{Yb}$ ratio is a reliable indicator of rare- 
TABLE 5

Chemical Analyses of Basalts from Hole 315A

\begin{tabular}{|c|c|c|c|c|c|c|c|c|c|c|}
\hline \multirow{2}{*}{$\begin{array}{c}\text { Flow Unit } \\
\text { Lab. No. } \\
\text { Sample } \\
\text { (Interval in cm) }\end{array}$} & \multirow{2}{*}{$\begin{array}{c}\text { IB } \\
\text { M121852 } \mathrm{W}^{\mathrm{a}} \\
31-1 \\
115.5-117.5\end{array}$} & \multicolumn{4}{|c|}{2} & \multicolumn{2}{|c|}{3} & \multirow{2}{*}{$\begin{array}{c}4 \\
\text { M121857 } \mathrm{W}^{\mathrm{a}} \\
32-4 \\
59-61\end{array}$} & \multirow{2}{*}{$\begin{array}{c}5 \mathrm{a} \\
\text { M121858 } \\
33-1, \\
116.5-118.5\end{array}$} & \multirow{2}{*}{$\begin{array}{c}6 \\
\text { M121859 } \mathrm{W}^{\mathrm{a}} \\
34-1 . \\
73.5-75.5\end{array}$} \\
\hline & & $\begin{array}{c}\text { M121853W } \\
32-1 \\
141.5-143.5\end{array}$ & $\begin{array}{c}\text { M121854 } \mathrm{W}^{\mathrm{a}} \\
32-2 \\
82.5-83.5\end{array}$ & $\begin{array}{c}\text { M121860wa } \\
32-2, \\
96-105\end{array}$ & $\begin{array}{c}\text { D103734 } \\
32-2, \\
96-105\end{array}$ & $\begin{array}{c}\text { M121855W } \\
32-3, \\
9.5-11.5\end{array}$ & $\begin{array}{c}\text { M121856 } \mathrm{W}^{\mathrm{a}} \\
32-3, \\
87.5-89.5\end{array}$ & & & \\
\hline $\mathrm{SiO}_{2}$ & 44.69 & 45.95 & 45.23 & 44.51 & 44.67 & 45.51 & 44.94 & 45.61 & 44.75 & 44.41 \\
\hline $\mathrm{Al}_{2} \mathrm{O}_{3}$ & 15.22 & 14.66 & 14.46 & 14.27 & 14.49 & 14.45 & 15.57 & 15.06 & 14.79 & 14.38 \\
\hline $\mathrm{Fe}_{2} \mathrm{O}_{3}$ & 7.72 & 6.68 & 8.56 & 7.07 & 5.88 & 6.86 & 6.52 & 5.92 & 6.88 & 7.48 \\
\hline $\mathrm{FeO}^{\mathrm{c}^{J}}$ & 4.17 & 6.12 & 4.34 & 6.29 & 7.03 & 6.00 & 5.46 & 6.72 & 6.24 & 5.58 \\
\hline $\mathrm{MgO}$ & 7.11 & 6.97 & 6.52 & 6.73 & 7.13 & 7.09 & 7.31 & 7.57 & 7.57 & 7.06 \\
\hline $\mathrm{CaO}$ & 6.95 & 6.01 & 6.77 & 7.00 & 6.66 & 6.61 & 7.00 & 7.46 & 5.98 & 5.65 \\
\hline $\mathrm{Na}_{2} \mathrm{O}^{\mathrm{c}}$ & 3.15 & 3.33 & 3.40 & 3.35 & 3.41 & 3.24 & 3.07 & 2.84 & 3.27 & 3.23 \\
\hline $\mathrm{K}_{2} \mathrm{O}$ & 0.31 & 0.40 & 0.48 & 0.42 & 0.46 & 0.45 & 0.35 & 0.26 & 0.46 & 050 \\
\hline $\mathrm{H}_{2} \mathrm{O}+\mathrm{d}$ & 1.78 & 1.66 & 1.36 & 3.00 & 1.86 & 2.77 & 3.23 & 3.56 & 3.28 & 3.21 \\
\hline $\mathrm{H}_{2} \mathrm{O}_{-} \mathrm{c}$ & 5.26 & 4.92 & 4.99 & 3.44 & 4.12 & 3.71 & 3.78 & 3.20 & 4.58 & 4.67 \\
\hline $\mathrm{TiO}_{2}$ & 2.29 & 2.55 & 2.91 & 2.92 & 2.93 & 2.77 & 2.22 & 2.27 & 2.53 & 2.85 \\
\hline $\mathrm{P}_{2} \mathrm{O}_{5}$ & 0.30 & 0.31 & 0.32 & 0.30 & 0.33 & 0.31 & 0.25 & 0.30 & 0.30 & 0.32 \\
\hline $\mathrm{MnO}^{\circ}$ & 0.46 & 0.34 & 0.33 & 0.40 & 0.40 & 0.39 & 0.33 & 0.24 & 0.25 & 0.36 \\
\hline $\mathrm{CO}_{2}{ }^{\mathrm{d}}$ & 0.25 & $<0.05$ & $<0.05$ & 0.22 & 0.45 & $<0.05$ & 0.09 & 0.09 & 0.20 & 0.05 \\
\hline $\mathrm{Cl}^{2}$ & 0.005 & 0.005 & 0.005 & 0.060 & n.d. & 0.005 & $<0.005$ & $<0.005$ & 0.010 & 0.005 \\
\hline $\mathrm{BaO}$ & 0.0111 & 0.0143 & 0.0145 & 0.0139 & n.d. & 0.0103 & 0.0108 & 0.0106 & 0.0161 & 0.0156 \\
\hline Sro & 0.0325 & 0.0280 & 0.0290 & 0.0280 & n.d. & 0.0280 & 0.0295 & 0.0285 & 0.0295 & 0.0320 \\
\hline$S$ & 0.111 & 0.052 & 0.032 & 0.153 & 0.20 & 0.167 & 0.139 & 0.103 & 0.116 & 0.058 \\
\hline $\mathrm{Rb}_{2} \mathrm{O}$ & $<0.0013$ & $<0.0013$ & $<0.0013$ & $<0.0013$ & n.d. & $<0.0013$ & $<0.0013$ & $<0.0013$ & $<0.0013$ & $<0.0013$ \\
\hline $\mathrm{SO}_{3}$ & n.d.g & n.d. & n.d. & n.d. & .00 & n.d. & n.d. & n.d. & n.d. & n.d. \\
\hline $\mathrm{Cr}_{2} \mathrm{O}_{3} \mathrm{e}$ & n.d. & n.d. & n.d. & n.d. & $<0.03$ & n.d. & n.d. & n.d. & n.d. & n.d. \\
\hline $\mathrm{NiO}^{\mathrm{f}^{J}}$ & n.d. & n.d. & n.d. & n.d. & 0.008 & n.d. & n.d. & n.d. & n.d. & n.d. \\
\hline Subtotal & - & - & - & - & 100.06 & - & - & - & - & - \\
\hline Less Zero & - & - & - & - & .10 & - & - & - & - & - \\
\hline Total & 99.81 & 100.00 & 99.75 & 100.17 & 99.96 & 100.37 & 100.30 & 101.24 & 101.26 & 99.86 \\
\hline
\end{tabular}

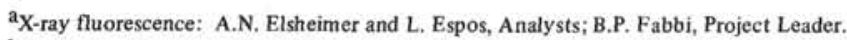

${ }^{b}$ Conventional rock analysis; Elaine L. Brandt, Analyst; D.R. Norton, Project Leader.

${ }^{C_{L}}$ Lois B. Schlocker, Analyst; F.O. Simon, Project Leader.

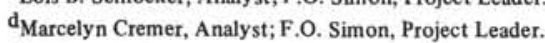

e'Colorimetric determination, G.D. Shipley, Analyst; Claude Huffman Jr., Project Leader.

${ }^{f}$ Atomic absorption, G.D. Shipley, Analyst; Claude Huffman Jr., Project Leader.

$\mathrm{g}_{\mathrm{n} . \mathrm{d} \text {. not determined, [in X-ray fluorescence analyses.] }}$

earth fractionation. The basalts of Hole 317A have $\mathrm{Ce} / \mathrm{Yb}$ ratios ranging from 0.5 to 1.2 , and average 0.8 . These presumably are in the range of Shih's (1974) "ocean ridge basalts." The basalts of Hole $315 \mathrm{~A}$, on the other hand, have $\mathrm{Ce} / \mathrm{Yb}$ ratios ranging from 2.0 to 2.6, and average 2.3. These values are intermediate between oceanic ridge tholeiites and Shih's (1974) "more alkaline" basalts from near Horizon Guyot, for which he gives values for $\mathrm{Ce} / \mathrm{Yb}$ of 4 to 8 .

Data for minor elements in both Hawaiian basalts and oceanic ridge tholeiites are at best scattered in the literature, and in part unpublished. We have compiled from existing data the ranges of concentrations and averages of selected minor elements in Hawaiian tholeiites, Hawaiian pre-erosional alkalic basalts, and oceanic ridge basalts (Tables 16a and 16b). It is apparent that a good deal of overlap occurs in minor-element concentrations of Hawaiian tholeiites and alkalic basalts (Table 15a). Five elements, $\mathrm{Co}, \mathrm{Cu}, \mathrm{Sc}, \mathrm{Ti}$, and $\mathrm{Y}$, as determined from the sources now available to us, are sufficiently overlapping as to be of little use in distinguishing the two types of basalt. However, the basalts of Hole 315A have $\mathrm{Ba}, \mathrm{Sr}$, and $\mathrm{V}$ values that are more similar to those typical of Hawaiian tholeiites than to Hawaiian alkalic basalts. In contrast, $\mathrm{Nb}$ and $\mathrm{Zr}$ show closer affinities to alkalic basalts, whereas $\mathrm{P}$ abundances are intermediate between the two Hawaiian lava types.
$\mathrm{Cr}, \mathrm{Cu}$, and $\mathrm{Ni}$ values are lower than those for either Hawaiian type, which may in part be explained as a result of the lack of olivine in most Hole 315A basalts. The minor-element concentrations of basalts from Hole $317 \mathrm{~A}$ and those of other oceanic ridge tholeiites are generally lower than those of Hawaiian rocks, except for $\mathrm{Nb}$ and $\mathrm{Zr}$, which occur in about the same abundance, and $\mathrm{Sc}$ and $\mathrm{Y}$, which are more abundant (Table 16b). The basalts of Hole 317A fall within reported ranges of composition of minor elements in oceanic ridge basalts for all of the 13 reported elements.

\section{Major Elements}

Major-element compositions, pyroxene analyses, and minor-element concentrations collectively indicate that the Hole 315A basalts are Hawaiian in type, but ambiguous as to whether they resemble Hawaiian tholeiites or alkalic basalts. Since the Hole 315A basalts do plot above Macdonald's (1968) total-alkali silica diagram, we have compared them with a suite of alkalic basalts of the Hawaiian pre-erosional types. Comparison of Table 17 with Table 13 shows that the dry reduced analyses of both sets of basalts are similar. $\mathrm{SiO}_{2}, \mathrm{Al}_{2} \mathrm{O}_{3}$, and $\mathrm{Na}_{2} \mathrm{O}$ are higher in the Hole $315 \mathrm{~A}$ basalts, whereas $\mathrm{CaO}$ and $\mathrm{K}_{2} \mathrm{O}$ are lower, on the average. A principal difference is that the Hole $315 \mathrm{~A}$ basalts contain $4.43 \%$ to $16.65 \%$ normative hypersthene, whereas the Hualalai basalts con- 
tain none. Figure 15 shows Hole $315 \mathrm{~A}$ basalts plotted on $\mathrm{MgO}$ variation diagrams along with the alkalic basalt analyses of Table 17 and Bass et al.'s (1973) analyses (also dry reduced in Table 17). Bass et al.'s (1973) analyses fall in a grouping considerably more alkalic than those of Hualalai basalts, being much richer in $\mathrm{Na}_{2} \mathrm{O}, \mathrm{K}_{2} \mathrm{O}, \mathrm{TiO}_{2}$, and $\mathrm{P}_{2} \mathrm{O}_{5}$ and lower in $\mathrm{SiO}_{2}, \mathrm{Al}_{2} \mathrm{O}_{3}$, and $\mathrm{CaO}$ when compared with the other two groups of rocks, and resemble the basanites and nephelinites of the post-erosional Honolulu Volcanic Series (Jackson and Wright, 1970). The analyses from Hole $315 \mathrm{~A}$, on the other hand, where they do not overlap values of the Hualalai basalts tend to diverge in a direction toward Hawaiian tholeiites (Wright, 1971). Total alkali-silica plots of the three sets of rocks (Figure 16) show that the basalts of Hole 315A tend to have higher $\mathrm{SiO}_{2}$ values than Hualalai basalts, but fall on the alkalic side of Macdonald's (1968) line. The same three groups of basalts are plotted on normative $\mathrm{Di}, \mathrm{Ol}, \mathrm{Hy}$, weight percent $\mathrm{FeO}$-total alkalis-MgO (AFM), and normative An$\mathrm{Ab}-\mathrm{Or}$ triangular diagrams in Figure 17. In the $\mathrm{Di}, \mathrm{Ol}$, Hy diagram, the Hualalai alkalic basalts and Bass et al.'s (1973) basanites and nephelinites have normative values such that plots fall of the $\mathrm{Di}, \mathrm{Ol}$ edge of the diagram; the Hole $315 \mathrm{~A}$ basalts plot in the lower central part of the diagram. In the AFM diagram, the basalts appear to follow a normal differentiation curve. In the An-Ab-Or diagram, the Hualalai alkalic basalts again plot in a field intermediate between the Hole 315A samples and those of Bass et al. (1973).

It seems clear that the basalts of Hole $315 \mathrm{~A}$ are compositionally similar to oceanic island basalts of the Hawaiian type. It is possible that they once were tholeiites that lost $\mathrm{SiO}_{2}$ and $\mathrm{CaO}$ and gained $\mathrm{Na}_{2} \mathrm{O}$ and $\mathrm{MgO}$ during alteration; it seems also possible, but less likely, that these rocks were once alkalic basalts that lost $\mathrm{CaO}$, $\mathrm{K}_{2} \mathrm{O}$, and $\mathrm{Al}_{2} \mathrm{O}_{3}$ and gained $\mathrm{SiO}_{2}$ during alteration. However, in view of the pyroxene compositions of these rocks and the intermediate distribution pattern of the "stable" minor elements, it seems most likely that the basalts sampled in Hole $315 \mathrm{~A}$ were originally truly transitional between oceanic island tholeiites and alkalic basalts.

The basalts of Hole 317A, on the other hand, are less altered than those of Hole $315 \mathrm{~A}$, and their major- and minor-element chemical composition and mineralogy all place them in the field of oceanic ridge tholeiites. It has been suggested (Andrews, Packham, et al., in press; Winterer et al., 1974) that the Manihiki and OntongJava plateaus were once connected; general similarities between the two areas are given in Part I of this volume. It is therefore of some interest to compare the oceanic ridge basalts of Hole 317A with those recovered from Hole 289 (Stoeser, in press; see Table 17). The OntongJava basalts are slightly richer in $\mathrm{K}_{2} \mathrm{O}, \mathrm{FeO}$, and $\mathrm{TiO}_{2}$ and slightly poorer in $\mathrm{MgO}$ and, in one analysis, poorer in $\mathrm{SiO}_{2}$ than the Manihiki basalts (Compare Tables 14 and 17). Figure 18 displays these relations on a $\mathrm{MgO}$ variation diagram that is more interesting for its similarities than its differences. Both the Ontong-Java and Manihiki basalts lie in the tholeiite field on a total alkali-silica diagram (Figure 19). An-Ab-Or, AFM, and
Di-Ol-Hy triangular diagrams (Figure 20) again show nearly identical plots of basalts from the two sites. There is certainly no chemical reason for the basalts of the two areas to have developed in a different setting.

\section{BASALTS OF HOLES 316 AND 318}

\section{Hole 316}

In Cores 19, 28, and 29 of Hole 316 several breccia beds contained small $(1 \mathrm{~mm}-1 \mathrm{~cm})$ clasts of scoriaceous basalt, for the most part altered to brown and green clay minerals. In the core catcher of Core 28 , an almost completely altered fragment of basalt of the some type was found that is about $1 \mathrm{~cm} \times 1 \mathrm{~cm} \times 4 \mathrm{~cm}$ in size (sample $316-28, \mathrm{CC})$.

In thin section, this sample proved to be an aphyric, scoriaceous basalt. Spherical vesicles ranging from 0.2 to $1.3 \mathrm{~mm}$ in diameter, and averaging $0.5 \mathrm{~mm}$, make up $45 \%$ of the rock. The former glassy groundmass of the basalt contains about $5 \%$ each of virtually unaltered microlites of plagioclase $(0.01 \times 0.05 \mathrm{~mm}$ in size $)$ and augite $(0.02 \mathrm{~mm}$ in size), although the former glass that contained the microlites is now altered to brown montmorillonite, which makes up about $45 \%$ of the rock. The vesicles are lined with brown montmorillonite, and about $40 \%$ of them are filled with calcite, analcime, and gmelinite. Calcite also appears to replace some groundmass montmorillonite.

All basalt clasts seen in Hole 316 appear to be nearly identical except in terms of degree of alteration. Nothing short of complete major- and minor-element chemical analyses of these rocks would yield their parentage, and even then, it might well be obscured by alteration. The presence of only one high-calcium pyroxene is these rocks is weak evidence for an alkalic parentage.

\section{Hole 318}

In Core 10 of Hole 318 , a breccia bed approximately $40 \mathrm{~cm}$ in thickness was encountered which was composed of nearly $50 \%$ of volcaniclastic debris. Some of the clasts of volcanic rocks are as much as $1 \mathrm{~cm}$ in diameter. These rocks are of a wide volcanic materials. Some are intersertal basalts with microphenocrysts of augite, groundmass plagioclase of composition $\mathrm{An}_{40-45}$, and altered groundmass glass. Some are quartz syenites, containing quartz, orthoclase, minor plagioclase, and aegerine augite. Some are mugearites and sanidine-rich trachytes. Two basaltic fragments were collected for closer inspection. One of these (318-10-1, 138-140 cm) proved to be an intersertal basalt containing about $20 \%$ phenocrysts of plagioclase $\left(\mathrm{An}_{58}\right)$ and augite $\left(\mathrm{Ca}_{42} \mathrm{Mg}_{44}\right.$ $\left.\mathrm{Fe}_{14}\right)$. Vesicles are small $(0.05-0.3 \mathrm{~mm})$, averaging about $0.2 \mathrm{~mm}$, make up about $5 \%$ of the rock, and are almost completely filled with calcite. A second generation of plagioclase microphenocrysts up to $0.6 \mathrm{~mm}$ in size appear to be present in the rock, and together with finer groundmass plagioclase, make up about $20 \%$ of the basalt. Groundmass augite $\left(\mathrm{Ca}_{40} \mathrm{Mg}_{43} \mathrm{Fe}_{17}\right)$ makes up about $25 \%$ of the rock. Both plagioclase and pyroxene are locally replaced by brown montmorillonite, and plagioclase by calcite. The remainder of the groundmass consists of former glass altered to brown mont- 
TABLE 6

Chemical Analyses of Basalts from Hole 317A

\begin{tabular}{|c|c|c|c|c|c|c|c|c|c|c|c|}
\hline Flow Unit & 1 & 2 & 3 & 4 & $5 \mathrm{~A}$ & \multicolumn{6}{|c|}{$5 B$} \\
\hline $\begin{array}{c}\text { Lab. No. } \\
\text { Sample } \\
\text { (Interval in cm) }\end{array}$ & $\begin{array}{l}\text { M121831W } \\
31-1, \\
144-146\end{array}$ & $\begin{array}{c}\text { M121832W } \\
31-2, \\
37-39\end{array}$ & $\begin{array}{c}\text { M121833W } \\
31-3 \text {, } \\
27-29\end{array}$ & $\begin{array}{c}\text { M121834W } \\
31-3, \\
101-103\end{array}$ & $\begin{array}{c}\text { M121835W } \\
31-4, \\
80-82\end{array}$ & $\begin{array}{c}M 121836 \mathrm{~W}^{\mathrm{a}} \\
32-1, \\
84-86\end{array}$ & $\begin{array}{c}\text { M121837W } \\
32-2, \\
75-77\end{array}$ & $\begin{array}{c}M 121851 W^{a} \\
32-3, \\
100-111.5\end{array}$ & $\begin{array}{c}\text { D103735 } \\
32-3, \\
100-111.5\end{array}$ & $\begin{array}{c}\text { M121838Wa } \\
32-3, \\
106-108\end{array}$ & $\begin{array}{c}\text { M121839Wa } \\
32-4, \\
76-78\end{array}$ \\
\hline $\mathrm{SiO}_{2}$ & 46.98 & 46.79 & 48.06 & 48.33 & 49.29 & 48.80 & 50.37 & 49.83 & 49.78 & 49.90 & 49.58 \\
\hline $\mathrm{Al}_{2} \mathrm{O}_{3}$ & 13.58 & 13.43 & 14.85 & 14.60 & 15.17 & 14.95 & 15.14 & 14.77 & 15.00 & 14.50 & 14.63 \\
\hline $\mathrm{Fe}_{2} \mathrm{O}_{3}$ & 5.56 & 5.39 & 4.46 & 4.59 & 3.69 & 4.48 & 3.91 & 4.51 & 4.17 & 4.47 & 3.75 \\
\hline $\mathrm{FeO}^{\mathrm{c}}$ & 5.00 & 5.14 & 4.80 & 4.86 & 5.72 & 5.72 & 6.75 & 6.64 & 7.00 & 6.90 & 7.07 \\
\hline $\mathrm{MgO}$ & 9.60 & 9.71 & 8.85 & 8.84 & 8.18 & 7.64 & 7.27 & 6.87 & 6.93 & 7.04 & 7.33 \\
\hline $\mathrm{CaO}$ & 9.19 & 8.97 & 10.91 & 11.08 & 11.07 & 11.08 & 10.87 & 11.18 & 11.07 & 10.79 & 10.88 \\
\hline $\mathrm{Na}_{2} \mathrm{O}^{\mathrm{c}}$ & 2.11 & 2.23 & 2.06 & 2.06 & 2.09 & 1.97 & 2.10 & 1.98 & 2.05 & 2.13 & 2.22 \\
\hline $\mathrm{K}_{2} \mathrm{O}$ & 0.04 & 0.04 & 0.05 & 0.02 & 0.09 & 0.02 & 0.12 & 0.09 & 0.12 & 0.11 & 0.06 \\
\hline $\mathrm{H}_{2} \mathrm{O}^{+\mathrm{d}}$ & 1.94 & 2.14 & 1.80 & 1.53 & 1.80 & 1.54 & 1.55 & 1.13 & 0.72 & 1.48 & 1.52 \\
\hline $\mathrm{H}_{2} \mathrm{O}^{-\mathrm{c}}$ & 5.06 & 4.60 & 2.99 & 2.59 & 2.66 & 2.26 & 1.89 & 1.64 & 1.91 & 1.56 & 1.87 \\
\hline $\mathrm{TiO}_{2}$ & 0.99 & 0.91 & 0.89 & 0.85 & 0.94 & 0.92 & 1.01 & 0.99 & 0.98 & 1.01 & 1.01 \\
\hline $\mathrm{P}_{2} \mathrm{O}_{5}$ & 0.12 & 0.13 & 0.12 & 0.13 & 0.12 & 0.12 & 0.14 & 0.10 & 0.08 & 0.13 & 0.12 \\
\hline $\mathrm{MnO}$ & 0.25 & 0.23 & 0.32 & 0.24 & 0.27 & 0.23 & 0.24 & 0.18 & 0.18 & 0.17 & 0.24 \\
\hline $\mathrm{CO}_{2} \mathrm{c}$ & $<0.05$ & $<0.05$ & $<0.05$ & $<0.05$ & $<0.05$ & $<0.05$ & 0.05 & $<0.05$ & 0.05 & $<0.05$ & $<0.05$ \\
\hline $\mathrm{Cl}$ & 0.045 & 0.05 & 0.035 & 0.04 & 0.035 & 0.02 & 0.02 & 0.025 & n.d. & 0.03 & 0.04 \\
\hline $\mathrm{BaO}$ & $<0.0025$ & $<0.0025$ & $<0.0025$ & $<0.0025$ & $<0.0025$ & $<0.0025$ & $<0.0025$ & $<0.0025$ & n.d. & $<0.0025$ & $<0.0025$ \\
\hline SrO & 0.0129 & 0.0130 & 0.0117 & 0.0118 & 0.0125 & 0.0118 & 0.0122 & 0.0109 & n.d. & 0.0125 & 0.0122 \\
\hline $\mathrm{s}$ & 0.015 & 0.011 & 0.011 & 0.013 & 0.013 & 0.010 & 0.009 & 0.009 & 0.00 & 0.009 & 0.009 \\
\hline $\mathrm{Rb}_{2} \mathrm{O}$ & $<0.0013$ & $<0.0013$ & $<0.0013$ & $<0.0013$ & $<0.0013$ & $<0.0013$ & $<0.0013$ & $<0.0013$ & n.d. & $<0.0013$ & $<0.0013$ \\
\hline $\mathrm{SO}_{3}$ & n.d. & n.d. & n.d. & n.d. & n.d. & n.d. & n.d. & n.d. & 0.00 & n.d. & n.d. \\
\hline $\mathrm{Cr}_{2} \mathrm{O}_{3}{ }^{\mathrm{e}}$ & n.d. & n.d. & n.d. & n.d. & n.d. & n.d. & n.d. & n.d. & $<0.03$ & n.d. & n.d. \\
\hline $\mathrm{NiO}^{\mathrm{f}}$ & n.d. & n.d. & n.d. & n.d. & n.d. & n.d. & n.d. & n.d. & 0.010 & n.d. & n.d. \\
\hline Subtotal & - & - & - & - & - & - & - & - & 100.08 & - & - \\
\hline Less Zero & - & - & - & - & - & & - & - & .00 & - & - \\
\hline Total & 100.49 & 99.78 & 100.22 & 99.78 & 101.15 & 99.77 & 101.45 & 99.95 & 100.08 & 100.24 & 100.34 \\
\hline Flow Unit & & $6 \mathrm{~A}$ & & & $6 \mathrm{~B}$ & & $7 \mathrm{~A}$ & $7 \mathrm{~B}$ & 9 & & 10 \\
\hline $\begin{array}{c}\text { Lab. No. } \\
\text { Sample } \\
\text { (Interval in cm) }\end{array}$ & $\begin{array}{c}\text { M121840wa } \\
32-4, \\
126-128\end{array}$ & $\begin{array}{l}\text { M121841W } \\
32-5 \text {, } \\
95-97\end{array}$ & $\begin{array}{c}\text { M121842Wa } \\
32-6, \\
113-115\end{array}$ & $\begin{array}{c}\text { M121843Wa } \\
33-1 \\
138-140\end{array}$ & $\begin{array}{l}\text { M121844W } \\
33-2 \\
82-84\end{array}$ & $\begin{array}{c}\text { M121845Wa } \\
33-3 \text {. } \\
94-96\end{array}$ & $\begin{array}{c}\text { M121846 } \mathrm{W}^{\mathrm{a}} \\
33-4, \\
103-105\end{array}$ & $\begin{array}{c}\text { M121847 Wa } \\
34-1 \\
40-41\end{array}$ & $\begin{array}{c}\text { M121848W } \\
34-2 \\
91-93\end{array}$ & $\begin{array}{c}\text { M121849W } \\
34-3 \\
118-120\end{array}$ & $\begin{array}{c}\text { M121850Wa } \\
34-4, \\
65-67\end{array}$ \\
\hline $\mathrm{SiO}_{2}$ & 48.22 & 48.47 & 48.30 & 49.26 & 48.84 & 47.88 & 49.38 & 49.22 & 50.05 & 50.42 & 49.92 \\
\hline $\mathrm{Al}_{2} \mathrm{O}_{3}$ & 13.84 & 13.23 & 12.88 & 13.18 & 13.92 & 14.62 & 14.76 & 14.59 & 14.71 & 14.19 & 15.07 \\
\hline $\mathrm{Fe}_{2} \mathrm{O}_{3}$ & 4.12 & 0.85 & 4.20 & 4.08 & 3.67 & 4.66 & 4.09 & 3.36 & 3.81 & 4.92 & 3.76 \\
\hline $\mathrm{FeO}^{\mathrm{c}}$ & 5.86 & 8.31 & 5.89 & 6.26 & 6.64 & 5.35 & 5.46 & 6.29 & 5.52 & 5.92 & 6.29 \\
\hline $\mathrm{MgO}$ & 9.03 & 9.66 & 9.63 & 9.15 & 8.56 & 8.41 & 8.14 & 7.93 & 7.48 & 7.46 & 7.29 \\
\hline $\mathrm{CaO}$ & 11.87 & 11.85 & 11.71 & 12.18 & 11.97 & 10.85 & 10.56 & 11.22 & 11.07 & 10.70 & 11.47 \\
\hline $\mathrm{Na}_{2} \mathrm{O}^{\mathrm{c}}$ & 1.83 & 1.73 & 1.69 & 1.82 & 1.86 & 2.13 & 2.30 & 2.19 & 2.25 & 2.37 & 2.19 \\
\hline $\mathrm{K}_{2} \mathrm{O}$ & 0.04 & 0.04 & 0.02 & 0.07 & 0.04 & 0.12 & 0.25 & 0.06 & 0.24 & 0.15 & 0.10 \\
\hline $\mathrm{H}_{2} \mathrm{O}^{+\mathrm{d}}$ & 1.77 & 2.09 & 1.97 & 1.45 & 1.52 & 2.02 & 1.47 & 1.26 & 1.05 & 1.30 & 0.88 \\
\hline $\mathrm{H}_{2} \mathrm{O}^{-\mathrm{c}}$ & 2.32 & 2.49 & 2.53 & 1.68 & 1.54 & 2.91 & 2.77 & 2.19 & 1.80 & 1.67 & 1.81 \\
\hline $\mathrm{TiO}_{2}$ & 0.81 & 0.81 & 0.80 & 0.82 & 0.88 & 0.89 & 1.08 & 1.01 & 1.07 & 1.15 & 1.06 \\
\hline
\end{tabular}




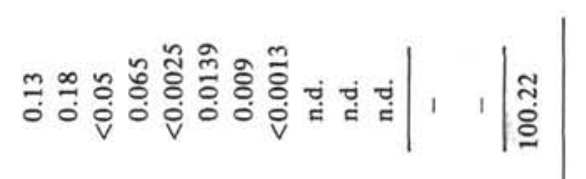

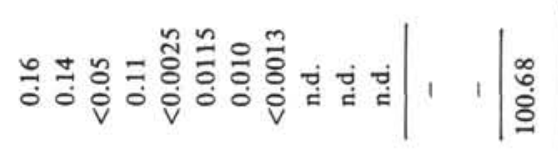

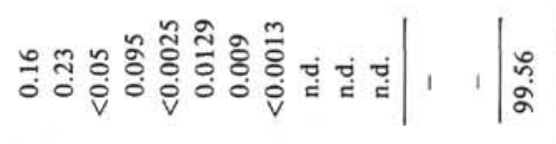

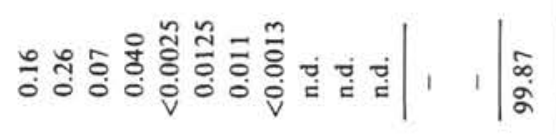

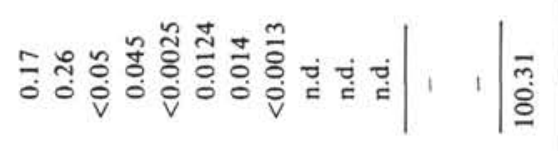

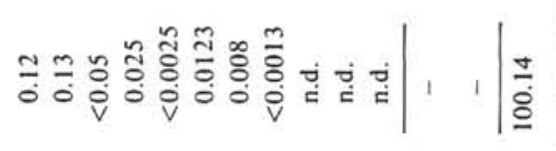

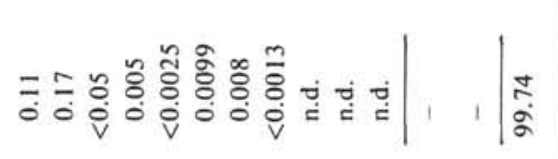

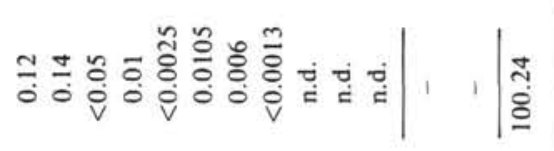

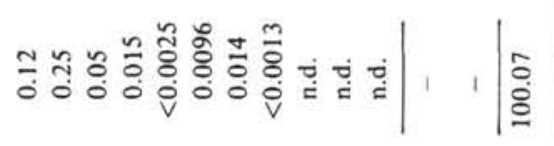

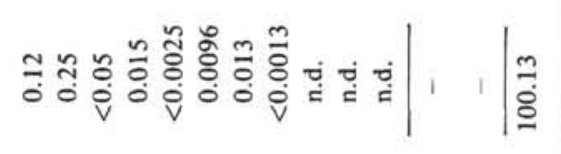

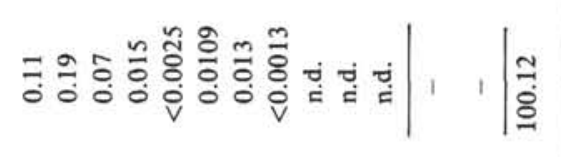

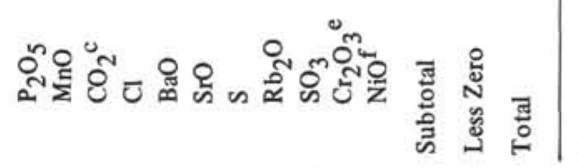

TABLE 7

Comparative $\mathrm{Na}_{2} \mathrm{O}$ Values (in percent) Between X-Ray Fluorescence (XRF) and Flame Photometer Values

\begin{tabular}{|c|c|c|c|}
\hline $\begin{array}{c}\text { Sample } \\
\text { (Interval in } \mathrm{cm} \text { ) }\end{array}$ & $\begin{array}{l}\text { XRF Low } \\
\text { Resolution }\end{array}$ & $\begin{array}{l}\text { XRF High } \\
\text { Resolution }\end{array}$ & $\begin{array}{c}\text { Flame } \\
\text { Photometer }\end{array}$ \\
\hline $317 \mathrm{~A}-31-1,144-146$ & 1.83 & 2.21 & 2.11 \\
\hline $317 \mathrm{~A}-31-2,37-39$ & 1.86 & 2.06 & 2.23 \\
\hline $317 \mathrm{~A}-31-3,27-29$ & 1.78 & 2.10 & 2.06 \\
\hline $317 \mathrm{~A}-31-3,101-103$ & 1.76 & 2.05 & 2.06 \\
\hline $317 A-31-4,80-82$ & 1.76 & 2.13 & 2.09 \\
\hline $317 A-32-1,84-86$ & 1.77 & 2.03 & 1.97 \\
\hline $317 A-32-2,75-77$ & 1.81 & 1.94 & 2.10 \\
\hline $317 \mathrm{~A}-32-3,106-108$ & 1.86 & 1.90 & 2.13 \\
\hline $317 A-32-4,76-78$ & 1.92 & 2.16 & 2.22 \\
\hline $317 A-32-4,126-128$ & 1.66 & 2.14 & 1.83 \\
\hline $317 A-32-5,95-97$ & 1.48 & 2.01 & 1.73 \\
\hline $317 A-32-6,113-115$ & 1.58 & 1.99 & 1.69 \\
\hline $317 \mathrm{~A}-33-1,138-140$ & 1.70 & 1.82 & 1.82 \\
\hline $317 A-33-2,82-84$ & 1.73 & 1.97 & 1.86 \\
\hline $317 \mathrm{~A}-33-3,94-96$ & 1.86 & 1.98 & 2.13 \\
\hline $317 \mathrm{~A}-33-4,103-105$ & 2.04 & 2.17 & 2.30 \\
\hline $317 \mathrm{~A}-34-1,40-41$ & 1.97 & 2.05 & 2.19 \\
\hline $317 \mathrm{~A}-34-2,91-93$ & 2.02 & 2.21 & 2.25 \\
\hline $317 \mathrm{~A}-34-3,118-120$ & 2.24 & 2.42 & 2.37 \\
\hline $317 A-34-4,65-67$ & 2.09 & 2.33 & 2.19 \\
\hline $317 \mathrm{~A}-32-3,100-111.5$ & 1.88 & 2.06 & 1.98 \\
\hline $315 \mathrm{~A}-31-1,115.5-117.5$ & 2.56 & 3.19 & 3.15 \\
\hline $315 A-32-1,141.5-143.5$ & 2.69 & 3.06 & 3.33 \\
\hline $315 A-32-2,82.5-83.5$ & 2.83 & 3.11 & 3.40 \\
\hline $315 A-32-3,9.5-11.5$ & 2.66 & 3.05 & 3.24 \\
\hline $315 A-32-3,87.5-89.5$ & 2.31 & 2.96 & 3.07 \\
\hline $315 A-32-4,59-61$ & 2.18 & 2.71 & 2.84 \\
\hline $315 A-33-1,116.5-118.5$ & 2.39 & 3.06 & 3.27 \\
\hline $315 A-34-1,73.5-75.5$ & 2.63 & 3.18 & 3.23 \\
\hline $315 A-32-2,96-105$ & 2.76 & 3.12 & 3.35 \\
\hline
\end{tabular}

morillonite. The sample resembles those of Flow Unit 6 in Hole $315 \mathrm{~A}$ but displays more abundant phenocrysts.

The other fragment studied $(318-10-1,139-141 \mathrm{~cm})$ proved to be an aphyric, vesicular, vitrophyric basalt. Vesicles have irregular to rounded shapes, range in size from 0.05 to $5.0 \mathrm{~mm}$, averaging $2.0 \mathrm{~mm}$, and make up nearly $30 \%$ of the rock. The groundmass consists of about $25 \%$ of very tiny plagioclase laths $\left(\mathrm{An}_{60}\right)$, augite prisms $\left(\mathrm{Ca}_{42} \mathrm{Mg}_{45} \mathrm{Fe}_{13}\right)$ that make up about $15 \%$ of the rock, and feathery ilmenite needles, all set in a matrix of former glass, now altered to brown montmorillonite that makes up the remaining $30 \%$ of the rock. The vesicles are lined with thin rims of brown montmorillonite and are partially filled with green montmorillonite and calcite. Plagioclase and augite are little altered. The rock resembles the upper chilled margin of Flow Unit $5 \mathrm{~A}$ in Hole $315 \mathrm{~A}$ but contains a considerably greater volume of vesicles.

Both these rocks appear to be tholeiites of the oceanic island type. Their association with mugearites and trachytes suggests that debris shed from the nearby Tuamotu edifices was of the oceanic island type.

\section{CONCLUSIONS}

Hole $317 \mathrm{~A}$ was drilled in the north-central part of Winterer et al.'s (1974) "high plateau" province of the Manihiki Plateau. Mudline was reached 2598 meters below sea level, and the drill bit entered the uppermost flow unit of basalt 3508 meters below sea level. Ten flow 
TABLE 8

Quantitative Spectrographic Analyses for Selected Minor Elements of Basalts from Hole $315 \mathrm{~A}^{\mathrm{a}}$

\begin{tabular}{cccccccc}
\hline Lab. No. & $\begin{array}{c}\text { Sample } \\
\text { (Interval in cm) }\end{array}$ & $\mathrm{Cr}(\mathrm{ppm})$ & $\mathrm{Nb}(\mathrm{ppm})$ & $\mathrm{Ni}(\mathrm{ppm})$ & $\mathrm{Zr}(\mathrm{ppm})$ & $\mathrm{Y}(\mathrm{ppm})$ & $\mathrm{V}(\mathrm{ppm})$ \\
\hline M121852W & $31-1,115.5-117.5$ & 140 & 33 & 69 & 170 & 41 & 180 \\
M121853W & $32-1,141.5-143.5$ & 105 & 39 & 62 & 205 & 47 & 170 \\
M121854W & $32-2,82.5-83.5$ & 110 & 40 & 43 & 200 & 60 & 280 \\
M121860W & $32-2,96-105$ & 61 & 34 & 38 & 165 & 48 & 280 \\
M121855W & $32-3,9.5-11.5$ & 92 & 44 & 54 & 230 & 56 & 225 \\
M121856W & $32-3,87.5-89.5$ & 145 & 32 & 92 & 170 & 39 & 200 \\
M121857W & $32-4,59-61$ & 140 & 35 & 90 & 180 & 51 & 225 \\
M121858W & $33-1,116.5-118.5$ & 105 & 41 & 86 & 190 & 51 & 275 \\
M121859W & $34-1,73.5-75.5$ & 73 & 41 & 57 & 220 & 56 & 280 \\
\hline
\end{tabular}

${ }^{a}$ Chris Heropoulos, Analyst; Brent Fabbi, Project Leader (Acting). Results reported to two significant figures with an overall accuracy of $\pm 15 \%$ (accuracy decreases near the limits of detection where only one digit is intended).

TABLE 9

Quantitative Spectrographic Analyses for Selected Minor Elements of Basalts From Hole 317A

\begin{tabular}{llcccccc}
\hline Lab. No. & $\begin{array}{c}\text { Sample } \\
\text { (Interval in cm) }\end{array}$ & $\mathrm{Cr}$ (ppm) & $\mathrm{Nb}$ (ppm) & $\mathrm{Ni}$ (ppm) & $\mathrm{Zr}$ (ppm) & $\mathrm{Y}$ (ppm) & $\mathrm{V}$ (ppm) \\
\hline M121831W & $31-1,144-146$ & 160 & $\mathrm{~N} 15^{\mathrm{b}}$ & 60 & 45 & 22 & 230 \\
M121832W & $31-2,37-39$ & 280 & $\mathrm{~N} 15$ & 92 & 60 & 21 & 215 \\
M121833W & $31-3,27-29$ & 400 & $\mathrm{~N} 15$ & 110 & 57 & 20 & 190 \\
M121834W & $31-3,101-103$ & 450 & $\mathrm{~N} 15$ & 94 & 69 & 16 & 170 \\
M121835W & $31-4,80-82$ & 220 & N15 & 81 & 70 & 25 & 220 \\
M121836W & $32-1,84-86$ & 230 & N15 & 73 & 75 & 24 & 215 \\
M121837W & $32-2,75-77$ & 170 & N15 & 66 & 84 & 27 & 225 \\
M121838W & $32-3,106-108$ & 145 & N15 & 65 & 86 & 21 & 230 \\
M121851W & $32-3,100-111.5$ & 135 & N15 & 62 & 70 & 34 & 235 \\
M121839W & $32-4,76-78$ & 130 & N15 & 62 & 75 & 25 & 235 \\
M121840W & $32-4,126-128$ & 610 & N15 & 110 & 72 & 25 & 200 \\
M121841W & $32-5,95-97$ & 920 & N15 & 120 & 76 & 21 & 200 \\
M121842W & $32-6,113-115$ & 580 & N15 & 96 & 64 & 24 & 210 \\
M121843W & $33-1,138-140$ & 550 & N15 & 75 & 58 & 25 & 240 \\
M121844W & $33-2,82-84$ & 430 & N15 & 75 & 64 & 20 & 160 \\
M121845W & $33-3,94-96$ & 325 & N15 & 67 & 66 & 19 & 170 \\
M121846W & $33-4,103-105$ & 325 & N15 & 75 & 84 & 27 & 180 \\
M121847W & $34-1,40-41$ & 420 & N15 & 88 & 68 & 30 & 180 \\
M121848W & $34-2,91-93$ & 370 & N15 & 83 & 84 & 26 & 190 \\
M121849W & $34-3,118-120$ & 370 & N15 & 91 & 92 & 14 & 125 \\
M121850W & $34-4,65-67$ & 350 & N15 & 87 & 83 & 30 & 200 \\
\hline
\end{tabular}

${ }^{a}$ Chris Heropoulos, Analyst; Brent Fabbi, Project Leader (Acting). Results reported to two significant figures with an overall accuracy of $\pm 15 \%$ (accuracy decreases near the limits of detection where only one digit is intended).

$\mathrm{b}_{\mathrm{N}}=$ not detected at value shown.

units of basalt are present; four are separated by three moderately thin beds of volcaniclastic siltstone. Although the textures of the basalts of the flow units. vary considerably, their major and minor chemical composition, their mineralogy, and their mineral compositions show only minor variations. These flow units are unquestionably oceanic ridge tholeiites of a type and composition found at or very near present-day spreading ridges. They undoubtedly formed at such a ridge, presumably the Pacific-Phoenix ridge (Larson and Chase, 1972), and spread northward into the Pacific plate some time prior to $110-120$ m.y. B.P. Alternatively, they may have initially formed near a triple junction, spread to the southeast or southwest and have been incorporated into the Pacific plate by a southward ridge jump that occurred about 100 m.y. B.P. (Winterer et al.,
1974). In either case, the chemical and mineralogic character of the basalts clearly refutes the idea that the high Manihiki Plateau is a subsided microcontinent (Heezen and Hollister, 1971), although refraction profiles in this area suggest rather thick oceanic crust (Sutton et al., 1970). Winterer et al. (1974) suggest that much of the high plateau might have been above sea level in the early part of its history, citing the presence of the coral atolls on its margins as the most direct evidence for its subsidence. The high volumetric proportion and the very large average sizes of vesicles in the basalts beneath the plateau support Winterer et al.'s (1974) contention; we suggest that the Manihiki flows were erupted at water depths of less than 400 meters, and, in the absence of any chemical data that these basalts contained unusually large amounts of volatile constituents, it is possible that 
TABLE 10

Minor-element Contents of Basalts From Hole $315 \mathrm{~A}^{\mathrm{a}}$

\begin{tabular}{|c|c|c|c|c|c|c|c|c|c|}
\hline $\begin{array}{c}\text { Lab. No. } \\
\text { Sample } \\
\text { (Interval in cm) } \\
\end{array}$ & $\begin{array}{c}\text { W-183470 } \\
31-1, \\
115.5-117.5\end{array}$ & $\begin{array}{c}\text { W-183471 } \\
32-1, \\
141.5-143.5\end{array}$ & $\begin{array}{c}\mathrm{W}-183472 \\
32-2, \\
82.5-83.5\end{array}$ & $\begin{array}{c}\mathrm{W}-183478 \\
32-2 \\
96-105\end{array}$ & $\begin{array}{c}\text { W-183473 } \\
32-3, \\
9.5-11.5\end{array}$ & $\begin{array}{c}\text { W-183474 } \\
32-3, \\
87.5-89.5 \\
\end{array}$ & $\begin{array}{c}\text { W- } 183475 \\
32-4 \\
59-61 \\
\end{array}$ & $\begin{array}{c}\text { W-183476 } \\
33-1, \\
116.5-118.5\end{array}$ & $\begin{array}{c}\text { W-183477 } \\
34-1, \\
73.5-75.5 \\
\end{array}$ \\
\hline $\mathrm{Co}(\mathrm{ppm})$ & 48.0 & 46.3 & 54.3 & 46.7 & 43.5 & 51.8 & 50.0 & 55.9 & 47.5 \\
\hline $\mathrm{Cr}(\mathrm{ppm})$ & 164 & 101 & 86 & 87 & 93 & 167 & 174 & 144 & 75 \\
\hline Cs (ppm) & $<1$ & $<1$ & $<1$ & $<1$ & $<1$ & $<1$ & $\dot{<} 1$ & $<1$ & $<1$ \\
\hline $\mathrm{Eu}(\mathrm{ppm})$ & 1.94 & 2.15 & 2.26 & 2.14 & 2.09 & 1.86 & 1.90 & 2.15 & 2.29 \\
\hline $\mathrm{Hf}(\mathrm{ppm})$ & 4.0 & 4.8 & 4.7 & 4.8 & 4.9 & 3.9 & 3.7 & 4.5 & 4.7 \\
\hline $\mathrm{Sc}(\mathrm{ppm})$ & 27.6 & 29.2 & 34.4 & 32.8 & 33.3 & 26.3 & 25.9 & 30.1 & 29.3 \\
\hline $\mathrm{Ta}(\mathrm{ppm})$ & 1.2 & 1.3 & 1.4 & 1.4 & 1.4 & 1.2 & 1.2 & 1.3 & 1.5 \\
\hline $\mathrm{Tb}(\mathrm{ppm})$ & 1.0 & 1.1 & 1.2 & 1.2 & 1.1 & 1.1 & 1.0 & 1.0 & 1.2 \\
\hline Th (ppm) & $<1.4$ & 2.0 & 2.0 & 1.5 & $<1.5$ & 1.2 & $<1.4$ & $<1.4$ & 1.4 \\
\hline $\mathrm{U}(\mathrm{ppm})^{\mathrm{b}}$ & 0.1 & 0.4 & 0.3 & 0.1 & 0.4 & $<0.1$ & 0.4 & 0.1 & 0.3 \\
\hline $\mathrm{Yb}(\mathrm{ppm})$ & 3.2 & 3.4 & 3.7 & 3.6 & 3.9 & 2.9 & 3.5 & 3.0 & 3.6 \\
\hline
\end{tabular}

${ }^{a}$ Radioactivation and radiochemistry determinations: L.J. Schwartz, Analyst; J.J. Rowe, Project Leader.

bFluorometric determination: Joseph Budinisky and Leuny Mei, Analysts; Frank Cuttitta, Supervisor.

they were subaerial. Thus, it would appear that the high Manihiki Plateau has subsided between 3000 and 3500 meters during the last $110-120$ m.y., assuming sea level at that time was near present levels (Hays and Pitman, 1973). It has further been suggested (Andrews and Packham, in press) that the Manihiki and Ontong-Java plateaus were once connected. Nothing in the comparative chemistry of the basalts in Hole $317 \mathrm{~A}$ and in those of Hole 289 (Stoeser, in press) precludes this possibility.

Hole $315 \mathrm{~A}$ was drilled $93 \mathrm{~km}$ from Fanning Island and is believed to have entered basalts related to that edifice. These basalts are more altered than those penetrated in Hole 317A, but their textures, major- and minor-element compositions, and mineralogy indicate that they are of the oceanic island type. They resemble Hawaiian tholeiites in that they contain hypersthene in their norms, and in that several minor elements are more closely related to such tholeiites than to alkalic basalts. On the other hand, they fall on the alkalic side of Macdonald's (1968) line separating alkalic basalts and tholeiites based on total alkali-silica plots; their pyroxenes proved to be salites, which are diagnostic of Hawaiian alkalic basalts; and several "stable" minor elements show alkalic rather than tholeiitic affinities. We conclude, overall, that the Hole $315 \mathrm{~A}$ basalts are truly transitional between Hawaiian tholeiites and alkalic basalts, but that their oceanic island affinities are clear-cut. At Site 165, in the northern Line Islands, Bass et al. (1973) drilled into potassic basanites and nephelinites, which, in Hawaii, are similar to post-erosional basalts erupted 2-4 m.y. after construction of the edifices upon which they rest. Jackson (1974) considers that these types of basalts could have formed at almost any time after pre-erosional oceanic island type rocks, if epirogenic processes affected the chain. The composition of the basalts at Hole 316, drilled in the southern Line Islands is unknown, but volcanogenic debris in that hole contains basalts that may be of oceanic island aspect. It would appear, from the nature of the basalts, that the Line Islands are formed of materials not unlike those of the Hawaiian Islands, although the Site 165 material is of the post-erosional type and we cannot say from the three existing sites whether or not the southern Line Islands are a progressive chain. The age of the sea floor along the entire Line Islands chain is poorly known, but if Larson and Chase's (1972) or Pitman et al.'s (1974) magnetic anomalies could be extended into the area, Site 165 would be older than anomaly M 10 , Site 315 would lie on an extension of magnetic anomaly M 4, and Hole 316 would lie in the interval between anomalies 33 and M 1. Alternatively, if Winterer's (this volume) model is correct, then the Line Islands could fall on an extension of the Hawaiian lineations, and nearly parallel to them. Although there are differences in opinion about the ages of these anomalies (Baldwin et al., 1974) and particularly over the interval between anomalies 33 and $M 1$, which might range in age from 80 to 120 m.y. B.P., extension of the anomalies across the chain would result in a crust that becomes younger southward along the Line Islands chain. On the other hand, if Winterer's (this volume) model is correct the oceanic crust beneath the Line Islands would be nearly coeval at about 100 m.y. B.P. In contrast, the age of basalt at Site 165 is given as $79-83$ m.y. B.P. (Winterer et al., 1974), at Site 315, $91.2 \pm 2.7$ m.y. B.P. (Lanphere and Dalrymple, this volume) and at Site 316 81-93 m.y. B.P. (Part I, this volume). These data would suggest that although we cannot say whether or not the Line Islands are a progressive chain, they do cut across older oceanic crust, as does the Hawaiian chain (Jackson et al., 1972). It might be suggested that the Line Islands themselves are an abandoned mid-oceanic ridge. The chemistry of the basalts at Sites 165 and 315 is clearly inconsistent with this model, unless the special case of an Icelandtype edifice, which does consist of basalts of the oceanic 
TABLE 11

Minor-element Contents of Basalts From Hole $317 \mathrm{~A}^{\mathrm{a}}$

\begin{tabular}{|c|c|c|c|c|c|c|c|}
\hline $\begin{array}{c}\text { Lab. No. } \\
\text { Sample } \\
\text { (Interval in cm) }\end{array}$ & $\begin{array}{c}\text { W-183449 } \\
31-1 \\
144-146\end{array}$ & $\begin{array}{c}\text { W-183450 } \\
31-2 \\
37-39\end{array}$ & $\begin{array}{c}\text { W-183451 } \\
31-3 \\
27-29\end{array}$ & $\begin{array}{c}\text { W-183452 } \\
31-3, \\
101-103\end{array}$ & $\begin{array}{c}\text { W- } 183453 \\
31-4 \\
80-82\end{array}$ & $\begin{array}{c}\text { W-183454 } \\
32-1, \\
84-86\end{array}$ & $\begin{array}{c}\text { W-183455 } \\
32-2, \\
75-77\end{array}$ \\
\hline $\mathrm{Ce}(\mathrm{ppm})$ & $<5$ & $<5$ & $<6$ & $<6$ & $<6$ & $<6$ & 7.5 \\
\hline Co (ppm) & 51.3 & 50.0 & 50.0 & 50.4 & 46.7 & 48.0 & 46 \\
\hline $\mathrm{Cr}(\mathrm{ppm})$ & 328 & 358 & 437 & 442 & 293 & 225 & 155 \\
\hline $\mathrm{Cs}(\mathrm{ppm})$ & $<1$ & $<1$ & $<1$ & $<1$ & $<1$ & $<1$ & $<1$ \\
\hline Eu (ppm) & 0.74 & 0.88 & 0.78 & 0.80 & 0.80 & 0.87 & 0.88 \\
\hline $\mathrm{Fe}(\%)$ & 7.64 & 7.19 & 6.60 & 6.77 & 6.70 & 7.62 & 7.53 \\
\hline $\mathrm{Gd}(\mathrm{ppm})$ & $<6$ & $<6$ & $<6$ & $<6$ & $<6$ & $<6$ & $<6$ \\
\hline $\mathrm{Hf}$ (ppm) & 1.2 & 1.2 & 1.2 & 1.3 & 1.3 & 1.3 & 1.3 \\
\hline $\mathrm{Sc}(\mathrm{ppm})$ & 41.1 & 40.4 & 44.2 & 43.5 & 44.7 & 44.5 & 43.5 \\
\hline $\mathrm{Ta}(\mathrm{ppm})$ & 0.3 & 0.2 & 0.3 & 0.3 & 0.3 & 0.3 & 0.2 \\
\hline $\mathrm{Tb}(\mathrm{ppm})$ & 0.4 & 0.4 & 0.4 & 0.4 & 0.5 & 0.4 & 0.4 \\
\hline Th (ppm) & $<1.5$ & $<1.6$ & $<1.6$ & $<1.6$ & $<1.6$ & $<1.6$ & $<1.6$ \\
\hline $\mathrm{U}(\mathrm{ppm})^{\mathrm{b}}$ & 0.1 & $<0.1$ & $<0.1$ & $<0.1$ & $<0.1$ & $<0.1$ & $<0.1$ \\
\hline $\mathrm{Yb}(\mathrm{ppm})$ & 2.0 & 2.1 & 1.7 & 1.8 & 2.1 & 2.3 & 2.5 \\
\hline $\mathrm{Zn}(\mathrm{ppm})$ & $<20$ & $<20$ & $<20$ & $<20$ & $<20$ & $<20$ & $<20$ \\
\hline $\mathrm{Zr}(\mathrm{ppm})$ & $<200$ & $<200$ & $<200$ & $<200$ & $<200$ & $<200$ & $<200$ \\
\hline Lab. No. & W-183469 & W-183456 & W-183457 & W-183458 & W-183459 & W-183460 & W-183461 \\
\hline $\begin{array}{c}\text { Sample } \\
\text { (Interval in } \mathrm{cm} \text { ) }\end{array}$ & $\begin{array}{c}32-3 \\
100-111.5\end{array}$ & $\begin{array}{c}32-3, \\
106-108\end{array}$ & $\begin{array}{l}32-4, \\
76-78\end{array}$ & $\begin{array}{c}32-4, \\
126-128\end{array}$ & $\begin{array}{l}32-5 \text {, } \\
95-97\end{array}$ & $\begin{array}{c}32-6, \\
113-115\end{array}$ & $\begin{array}{c}33-1, \\
138-140\end{array}$ \\
\hline $\mathrm{Ce}(\mathrm{ppm})$ & $<5$ & 8.4 & 9.5 & 6.9 & 7.2 & $<6$ & $<6$ \\
\hline Co (ppm) & 47.0 & 48.3 & 48.2 & 41.1 & 49.8 & 49.9 & 50.2 \\
\hline $\mathrm{Cr}(\mathrm{ppm})$ & 130 & 125 & 134 & 486 & 683 & 639 & 637 \\
\hline Cs (ppm) & $<1$ & $<1$ & $<1$ & $<1$ & $<1$ & $<1$ & $<1$ \\
\hline $\mathrm{Eu}(\mathrm{ppm})$ & 0.91 & 0.89 & 0.89 & 0.88 & 0.73 & 0.70 & 0.74 \\
\hline $\mathrm{Fe}(\%)$ & 7.89 & 8.55 & 8.21 & 7.69 & 6.77 & 7.39 & 7.71 \\
\hline $\mathrm{Gd}(\mathrm{ppm})$ & $<6$ & $<6$ & $<6$ & $<6$ & $<6$ & $<6$ & $<6$ \\
\hline $\mathrm{Hf}(\mathrm{ppm})$ & 1.6 & 1.6 & 1.5 & 1.2 & 0.9 & 0.9 & 1.1 \\
\hline Sc (ppm) & 43.0 & 44.2 & 43.9 & 46.5 & 48.4 & 46.1 & 47.2 \\
\hline $\mathrm{Ta}(\mathrm{ppm})$ & 0.3 & 0.2 & 0.2 & 0.3 & 0.4 & 0.3 & 0.2 \\
\hline $\mathrm{Tb}(\mathrm{ppm})$ & 0.5 & 0.6 & 0.5 & 0.4 & 0.4 & 0.4 & 0.5 \\
\hline $\mathrm{Th}(\mathrm{ppm})$ & $<1.6$ & $<1.6$ & $<1.6$ & $<1.7$ & $<1.7$ & $<1.6$ & $<1.7$ \\
\hline $\mathrm{U}(\mathrm{ppm})^{\mathrm{b}}$ & 0.1 & $<0.1$ & 0.1 & 0.1 & $<0.1$ & $<0.1$ & $<0.1$ \\
\hline $\mathrm{Yb}(\mathrm{ppm})$ & 2.5 & 2.5 & 2.3 & 2.0 & 2.1 & 2.0 & 2.1 \\
\hline $\mathrm{Zn}(\mathrm{ppm})$ & $<16$ & $<20$ & $<20$ & $<20$ & $<20$ & $<20$ & $<20$ \\
\hline $\mathrm{Zr}(\mathrm{ppm})$ & $<200$ & $<200$ & $<200$ & $<200$ & $<200$ & $<200$ & $<200$ \\
\hline Lab. No. & W-183462 & W-183463 & W-183464 & W-183465 & W-183466 & W-183467 & W-183468 \\
\hline $\begin{array}{c}\text { Sample } \\
\text { (Interval in } \mathrm{cm} \text { ) }\end{array}$ & $\begin{array}{l}33-2, \\
82-84\end{array}$ & $\begin{array}{l}33-3 \text {, } \\
94-96\end{array}$ & $\begin{array}{l}33-4, \\
103-105\end{array}$ & $\begin{array}{l}34-1 \\
40-41\end{array}$ & $\begin{array}{l}34-2 \\
91-93\end{array}$ & $\begin{array}{c}34-3 \\
118-120\end{array}$ & $\begin{array}{l}34-4 \\
65-67\end{array}$ \\
\hline $\mathrm{Ce}(\mathrm{ppm})$ & $<6$ & 6.0 & 11.8 & 10.2 & 11.9 & $<6$ & 11.2 \\
\hline $\mathrm{Co}(\mathrm{ppm})$ & 48.1 & 50.5 & 44.5 & 44.2 & 41.8 & 45.9 & 44.0 \\
\hline $\mathrm{Cr}(\mathrm{ppm})$ & 441 & 377 & 408 & 420 & 425 & 357 & 346 \\
\hline Cs (ppm) & $<1$ & $<1$ & $<1$ & $<1$ & $<1$ & $<1$ & $<1$ \\
\hline $\mathrm{Eu}(\mathrm{ppm})$ & 0.75 & 0.79 & 0.95 & 0.87 & 0.97 & 1.03 & 0.91 \\
\hline $\mathrm{Fe}(\%)$ & 7.33 & 6.91 & 6.77 & 7.02 & 6.56 & 8.09 & 7.66 \\
\hline $\mathrm{Gd}(\mathrm{ppm})$ & $<6$ & $<6$ & $<6$ & $<6$ & $<6$ & $<6$ & $<6$ \\
\hline $\mathrm{Hf}(\mathrm{ppm})$ & 1.3 & 1.1 & 1.6 & 1.7 & 1.7 & 1.7 & 1.6 \\
\hline Sc (ppm) & 44.2 & 44.3 & 43.3 & 42.1 & 43.5 & 45.3 & 42.4 \\
\hline $\mathrm{Ta}(\mathrm{ppm})$ & 0.3 & 0.3 & 0.3 & 0.3 & 0.3 & 0.3 & 0.3 \\
\hline $\mathrm{Tb}(\mathrm{ppm})$ & 0.4 & 0.4 & 0.5 & 0.5 & 0.5 & 0.6 & 0.5 \\
\hline Th (ppm) & $<1.6$ & $<1.5$ & $<1.6$ & $<1.6$ & $<1.6$ & $<1.6$ & $<1.6$ \\
\hline $\mathrm{U}(\mathrm{ppm})^{\mathrm{b}}$ & 0.1 & 0.1 & 0.1 & 0.1 & $<0.1$ & $<0.1$ & $<0.1$ \\
\hline $\mathrm{Yb}(\mathrm{ppm})$ & 2.0 & 2.0 & 2.3 & 2.2 & 2.2 & 2.6 & 2.1 \\
\hline $\mathrm{Zn}(\mathrm{ppm})$ & $<20$ & $<20$ & $<20$ & $<20$ & $<20$ & $<20$ & $<20$ \\
\hline $\mathrm{Zr}(\mathrm{ppm})$ & $<200$ & $<200$ & $<200$ & $<200$ & $<200$ & $<200$ & $<200$ \\
\hline
\end{tabular}

${ }^{a}$ Radioactivation and radiochemistry determinations; L.J. Schwartz, Analyst; J.J. Rowe, Project Leader.

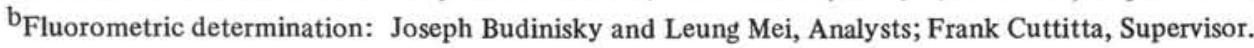


TABLE 12

Mineral Analyses of Plagioclases (pc) and Pyroxenes (px) From the Basalts of Holes 315A and 317 $\mathrm{A}^{\mathrm{a}}$

\begin{tabular}{|c|c|c|c|c|c|c|c|c|c|c|}
\hline \multicolumn{7}{|c|}{ Hole $315 \mathrm{~A}$} & \multicolumn{4}{|c|}{ Hole $317 \mathrm{~A}$} \\
\hline $\begin{array}{c}\text { Sample } \\
\text { (Interval } \\
\text { in } \mathrm{cm} \text { ) }\end{array}$ & \multicolumn{2}{|c|}{$32-2,79.5-80$} & \multicolumn{2}{|c|}{$32-4,53-55$} & \multicolumn{2}{|c|}{$34-1,99-101$} & \multicolumn{4}{|c|}{$31-2,37-39$} \\
\hline $\begin{array}{c}\text { Flow } \\
\text { Unit }\end{array}$ & \multicolumn{2}{|c|}{2} & \multicolumn{2}{|c|}{4} & \multicolumn{2}{|c|}{6} & \multicolumn{4}{|c|}{2} \\
\hline Mineral & $\mathrm{pc}$ & $\mathrm{px}$ & pc & $\mathrm{px}$ & $\mathrm{pc}$ & $\mathrm{px}$ & $\mathrm{pc}$ & $\mathrm{px}$ & $\mathrm{px}$ & $\mathrm{px}$ \\
\hline Textureb & $\mathrm{m}$ & $\mathrm{m}$ & $\mathrm{g}$ & $\mathrm{g}$ & $\mathrm{m}$ & $\mathrm{m}$ & $\mathrm{g}$ & $\mathrm{m}$ & $\mathrm{g}$ & $\mathrm{m}$ \\
\hline $\mathrm{SiO}_{2}{ }^{\mathrm{c}}$ & 50.87 & 46.8 & 52.18 & 49.9 & 51.08 & 47.9 & 49.89 & 54.1 & 53.2 & 53.4 \\
\hline $\mathrm{Al}_{2} \mathrm{O}_{3}$ & 28.81 & 6.30 & 28.76 & 3.33 & 29.10 & 5.37 & 29.49 & 2.04 & 2.20 & 2.61 \\
\hline $\mathrm{FeO}$ & - & 9.6 & - & 11.1 & - & 10.3 & - & 5.3 & 5.2 & 5.7 \\
\hline $\mathrm{MgO}$ & - & 9.8 & - & 11.0 & - & 9.9 & - & 19.1 & 18.7 & 17.9 \\
\hline $\mathrm{CaO}$ & 12.78 & 20.9 & 12.30 & 19.6 & 12.84 & 20.9 & 14.14 & 18.8 & 19.2 & 19.6 \\
\hline $\mathrm{Na}_{2} \mathrm{O}$ & 4.31 & 0.51 & 4.53 & 0.43 & 4.35 & 0.46 & 3.39 & 0.17 & 0.18 & 0.19 \\
\hline $\mathrm{K}_{2} \mathrm{O}$ & 0.18 & - & 0.31 & - & 0.30 & - & 0.26 & - & - & - \\
\hline $\mathrm{TiO}_{2}$ & - & 3.60 & - & 1.83 & - & 2.85 & - & 0.27 & 0.28 & 0.34 \\
\hline $\mathrm{MnO}$ & - & 1.0 & - & 1.2 & - & 1.1 & - & 0.7 & 0.6 & 0.7 \\
\hline Total & 96.95 & 98.51 & 98.08 & 98.39 & 97.67 & 98.78 & 97.17 & 100.48 & 99.56 & 100.44 \\
\hline
\end{tabular}

Numbers of Ions on the Basis of 32 Oxygens for Plagioclase and 6 Oxygens for Pyroxene ${ }^{d}$

\begin{tabular}{|c|c|c|c|c|c|c|c|c|c|c|c|c|c|c|c|c|c|c|c|c|}
\hline $\begin{array}{l}\mathrm{Si} \\
\mathrm{Al} \text { (IV) }\end{array}$ & $\left.\begin{array}{l}9.539 \\
6.367\end{array}\right\}$ & 15.91 & $\left.\begin{array}{l}1.794 \\
0.206\end{array}\right\}$ & 2.00 & $\left.\begin{array}{l}9.653 \\
6.271\end{array}\right\}$ & 15.92 & $\left.\begin{array}{l}1.913 \\
0.088\end{array}\right\}$ & 2.00 & $\begin{array}{l}9.516 \\
6.389\end{array}$ & 15.91 & $\left.\begin{array}{l}1.834 \\
0.166\end{array}\right\}$ & 2.00 & $\left.\begin{array}{l}9.363 \\
0.523\end{array}\right\}$ & 15.89 & $\left.\begin{array}{l}1.955 \\
0.045\end{array}\right\}$ & 2.00 & $\left.\begin{array}{l}1.944 \\
0.056\end{array}\right\}$ & 2.00 & $\left.\begin{array}{l}1.940 \\
0.060\end{array}\right\}$ & 2.00 \\
\hline Al & - & & 0.079 & & - & & 0.063 & & - & & 0.076 & & - & & 0.042 & & 0.039 ) & & 0.052 & \\
\hline $\mathrm{Ti}$ & - & & 0.104 & & - & & 0.053 & & - & & 0.082 & & - & & 0.007 & & 0.008 & & 0.009 & \\
\hline $\mathrm{Mg}$ & - & & 0.560 & & - & & 0.638 & & - & & 0.565 & & - & & 1.029 & & 1.019 & & 0.969 & \\
\hline $\mathrm{Fe}^{2+}$ & - & & 0.308 & 198 & - & & 0.356 & 198 & - & & 0.330 & 198 & - & & 0.160 & 200 & 0.159 & 201 & 0.173 & 2.00 \\
\hline Mn & - & & 0.033 & 1.98 & - & & 0.039 & 1.98 & - & & 0.036 & 1.98 & - & & $0.021\}$ & 2.00 & $0.019\}$ & 2.01 & 0.022 & 2.00 \\
\hline $\mathrm{Ca}$ & 2.568 & & 0.758 & & 2.433 & & 0.805 & & 2.563 & & 0.857 & & 2.843 & & 0.728 & & 0.752 & & 0.763 & \\
\hline $\mathrm{Na}$ & $1.567\}$ & 4.18 & 0.098 & & 1.625 & 4.14 & 0.032 & & 1.571 & 4.21 & 0.034 & & 1.234 & 4.14 & 0.012 & & 0.013 & & 0.013 & \\
\hline K & 0.043 & & - & & 0.073 & & - & & 0.071 & & - & & 0.062 & & - & & - & & - & \\
\hline$\Sigma$ & 20.08 & & 3.98 & & 20.06 & & 3.98 & & 20.11 & & 3.98 & & 20.03 & & 4.00 & & 4.01 & & 4.00 & \\
\hline K & 1.0 & & & & 1.8 & & & & 1.7 & & & & 1.5 & & & & & & & \\
\hline $\mathrm{Na}$ & 37.5 & & & & 39.3 & & & & 37.4 & & & & 29.8 & & & & & & & \\
\hline $\mathrm{Ca}$ & 61.5 & & & & 58.9 & & & & 60.9 & & & & 68.7 & & & & & & & \\
\hline $\mathrm{Mg}$ & & & 32.4 & & & & 35.1 & & & & 32.2 & & & & 53.7 & & 52.8 & & 50.9 & \\
\hline $\mathrm{Fe}$ & & & 17.8 & & & & 19.9 & & & & 18.8 & & & & 8.4 & & 8.2 & & 9.1 & \\
\hline $\mathrm{Ca}$ & & & 49.7 & & & & 45.0 & & & & 48.9 & & & & 38.0 & & 39.0 & & 40.0 & \\
\hline
\end{tabular}

aM. H. Beeson, analyst.

$\mathrm{b}_{\mathrm{g}}=$ groundmass and $\mathrm{m}=$ microphenocryst.

Oxides as received.

${ }^{d}$ Derived from computer program of Jackson et al. (1967), modified by Wright (1970). 
TABLE 12 - Continued

\begin{tabular}{|c|c|c|c|c|c|c|c|c|c|c|c|c|c|c|c|c|c|c|c|c|c|}
\hline \multicolumn{22}{|c|}{ Hole 317A } \\
\hline $\begin{array}{l}\text { Sample } \\
\text { (Interval } \\
\text { in } \mathrm{cm} \text { ) }\end{array}$ & \multicolumn{6}{|c|}{$31-2,37-39$} & \multicolumn{6}{|c|}{$32-5,111.5-112$} & \multicolumn{9}{|c|}{$34-1,40-41$} \\
\hline $\begin{array}{c}\text { Flow } \\
\text { Unit }\end{array}$ & \multicolumn{6}{|c|}{2} & \multicolumn{6}{|c|}{ 5B } & \multicolumn{9}{|c|}{$7 \mathrm{~B}$} \\
\hline Mineral & \multicolumn{2}{|l|}{$\mathrm{px}$} & \multicolumn{2}{|l|}{$\mathrm{px}$} & \multicolumn{2}{|l|}{$\mathrm{px}$} & \multicolumn{2}{|c|}{$\mathrm{pc}$} & \multicolumn{2}{|l|}{$\mathrm{px}$} & \multicolumn{2}{|l|}{$\mathrm{px}$} & $\mathrm{px}$ & \multicolumn{2}{|l|}{ pc } & \multicolumn{2}{|l|}{$\mathrm{px}$} & \multicolumn{2}{|l|}{$\mathrm{px}$} & \multicolumn{2}{|l|}{$\mathrm{px}$} \\
\hline Textureb & \multicolumn{2}{|l|}{$\mathrm{m}$} & \multicolumn{2}{|l|}{$\mathrm{g}$} & \multicolumn{2}{|l|}{$\mathrm{g}$} & \multicolumn{2}{|l|}{$\mathrm{g}$} & $\mathrm{m}$ & & $\mathrm{m}$ & & $\mathrm{g}$ & $\mathrm{g}$ & & $\mathrm{g}$ & & g & & $\mathrm{g}$ & \\
\hline $\mathrm{SiO}_{2}{ }^{\mathrm{c}}$ & 52.8 & & 53.2 & & 50.8 & & 52.69 & & 49.3 & & 48.8 & & 52.7 & 51.38 & & 52.5 & & 52.6 & & 53.8 & \\
\hline $\mathrm{Al}_{2} \mathrm{O}_{3}$ & 2.89 & & 2.97 & & 3.95 & & 28.18 & & 1.21 & & 1.11 & & 1.84 & 29.16 & & 2.15 & & 1.97 & & 1.88 & \\
\hline $\mathrm{FeO}$ & 5.9 & & 5.9 & & 8.2 & & - & & 20.1 & & 20.8 & & 8.7 & - & & 8.3 & & 12.3 & & 6.4 & \\
\hline $\mathrm{MgO}$ & 17.3 & & 17.5 & & 16.7 & & - & & 8.0 & & 6.3 & & 15.8 & - & & 15.3 & & 18.2 & & 18.2 & \\
\hline $\mathrm{CaO}$ & 19.7 & & 18.6 & & 14.3 & & 11.86 & & 13.7 & & 13.9 & & 17.8 & 13.20 & & 18.0 & & 11.7 & & 18.1 & \\
\hline $\mathrm{Na}_{2} \mathrm{O}$ & 0.19 & & 0.18 & & 0.28 & & 4.58 & & 0.17 & & 0.19 & & 0.21 & 4.06 & & 0.20 & & 0.16 & & 0.16 & \\
\hline $\mathrm{K}_{2} \mathrm{O}$ & - & & - & & - & & 0.24 & & - & & - & & - & 0.19 & & - & & - & & - & \\
\hline $\mathrm{TiO}_{2}$ & 0.48 & & 0.47 & & 0.51 & & - & & 0.73 & & 0.68 & & 0.43 & - & & 0.61 & & 0.58 & & 0.39 & \\
\hline $\mathrm{MnO}$ & 0.8 & & 0.5 & & 0.6 & & - & & 1.8 & & 1.7 & & 0.7 & - & & 0.9 & & 0.9 & & 0.7 & \\
\hline Total & 100.06 & & 99.32 & & 95.34 & & 97.55 & & 95.01 & & 93.48 & & 98.18 & 97.99 & & 97.96 & & 98.41 & & 99.63 & \\
\hline & & & & & Numb & bers of & ons on the & e Basis & 32 Oxyger & ens for & Plagioclas & se and & 6 Oxygens for & yroxene $^{d}$ & & & & & & & \\
\hline $\mathrm{Si}$ & 1.930 & 2.00 & $1.948\}$ & 2.00 & $1.939\}$ & 2.00 & $9.774\}$ & 15.94 & $2.013\}$ & 2.01 & $2.035\}$ & 2.03 & $1.976\}_{2.00}$ & $9.531\}$ & 15.91 & $1.972\}$ & 2.00 & $1.967\}$ & 2.00 & $1.967\}$ & 2.00 \\
\hline $\mathrm{Al}$ (IV) & 0.070 & 2.00 & $0.053\}$ & 2.00 & $0.061\}$ & $\int^{2.00}$ & $6.161\}$ & 15.94 & $0.0\}$ & \}$^{2.01}$ & $0.0\}$ & 2.03 & $0.024\}^{2.00}$ & $6.375\}$ & \}$^{15.91}$ & $0.028\}$ & 2.00 & $0.033\}$ & 2.00 & 0.033 & 2.00 \\
\hline $\mathrm{Al}$ & 0.055 & & 0.076 & & 0.117 & & - & & 0.058 & & 0.055 & & $0.058)$ & - & & 0.068 & & 0.054 & & 0.048 & \\
\hline $\mathrm{Ti}$ & 0.013 & & 0.013 & & 0.015 & & - & & 0.022 & & 0.021 & & 0.012 & - & & 0.017 & & 0.016 & & 0.011 & \\
\hline $\mathrm{Mg}$ & 0.943 & & 0.955 & & 0.950 & & - & & 0.487 & & 0.342 & & 0.883 & - & & 0.857 & & 1.015 & & 0.992 & \\
\hline $\mathrm{Fe}^{2+}$ & 0.180 & ( & 0.181 & 108 & 0.260 & 1,07 & - & & 0.686 & (1) & 0.725 & 1180 & 0.273 & - & & 0.261 & 1,97 & 0.385 & 1,08 & 0.196 & 190 \\
\hline $\mathrm{Mn}$ & 0.025 & 2.00 & 0.016 & 1.98 & $0.019\}$ & \}$^{1.91}$ & - & & 0.062 & 1.94 & $0.060\}$ & 1.89 & $0.022\}^{1.98}$ & - & & 0.029 & 1.97 & 0.029 & 1.98 & 0.022 & 1.99 \\
\hline $\mathrm{Ca}$ & 0.772 & & 0.730 & & 0.585 & & $2.357)$ & & 0.599 & & 0.621 & & 0.715 & 2.623 & & 0.725 & & 0.469 & & 0.709 & \\
\hline $\mathrm{Na}$ & 0.014 & & 0.013 & & 0.021 & & $1.647\}$ & 4.06 & 0.014 & & 0.015 & & 0.015 & 1.460 & 4.13 & 0.015 & & 0.012 & & 0.011 & \\
\hline $\mathrm{K}$ & - & & - J & & - & & 0.057 & & - & & - & & - & 0.045 & & - & & - & & $-J$ & \\
\hline$\Sigma$ & 4.00 & & 3.98 & & 3.98 & & $20.00^{J}$ & & 3.94 & & 3.92 & & 3.98 & 20.03 & & 3.97 & & 3.98 & & 3.99 & \\
\hline K & & & & & & & 1.4 & & & & & & & 1.1 & & & & & & & \\
\hline $\mathrm{Na}$ & & & & & & & 40.6 & & & & & & & 35.4 & & & & & & & \\
\hline $\mathrm{Ca}$ & & & & & & & 58.0 & & & & & & & 63.5 & & & & & & & \\
\hline $\mathrm{Mg}$ & 49.8 & & 51.2 & & 52.9 & & & & 27.5 & & 22.5 & & 47.2 & & & 46.5 & & 54.3 & & 52.3 & \\
\hline $\mathrm{Fe}$ & 9.5 & & 9.7 & & 14.6 & & & & 38.7 & & 41.7 & & 14.6 & & & 14.2 & & 20.6 & & 10.3 & \\
\hline $\mathrm{Ca}$ & 40.7 & & 39.1 & & 32.5 & & & & 33.8 & & 35.7 & & 38.2 & & & 39.3 & & 25.1 & & 37.4 & \\
\hline
\end{tabular}

$\mathrm{b}_{\mathrm{g}}=$ groundmass and $\mathrm{m}=$ microphenocryst.

${ }^{c}$ Oxides as received.

${ }^{d}$ Derived from computer program of Jackson et al. (1967), modified by Wright (1970). 


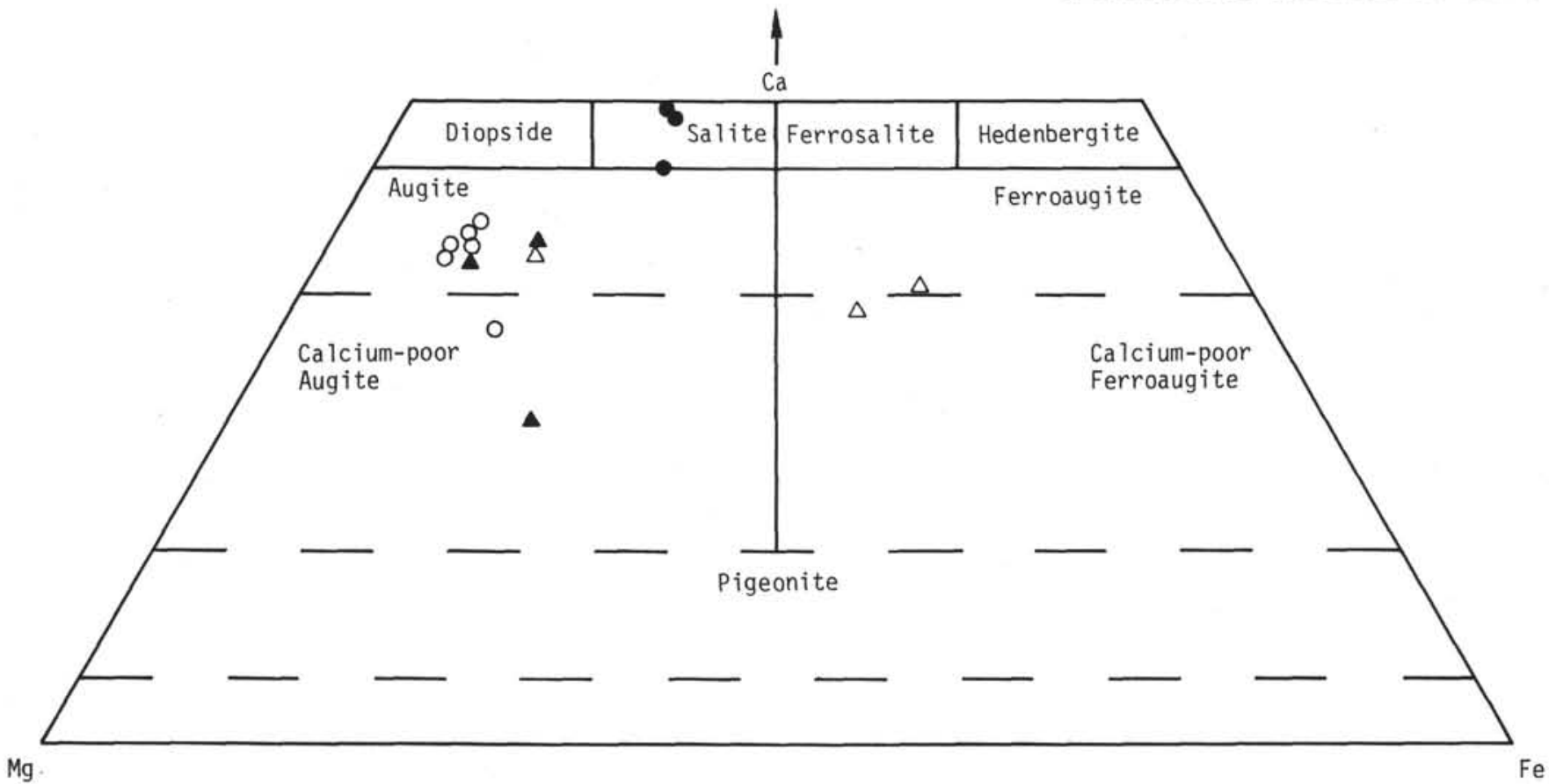

Figure 5. Ca-Mg-Fe ternary diagram (fields modified from Hess, 1941) for pyroxenes from basalts of Holes $315 \mathrm{~A}$ and $317 \mathrm{~A}$. (Solid circles from Hole 315A; open circles from 317A-31-2, 37-39 cm; closed triangles from 317A-34-1, 40-41 cm; and open triangles from $317 A-32-3,111.5-113 \mathrm{~cm}$ ).

TABLE 13

Dry Reduced Chemical Analyses and Norms of Basalts from Hole $315 \mathrm{~A}^{\mathrm{a}}$

\begin{tabular}{|c|c|c|c|c|c|c|c|c|c|c|}
\hline \multirow{2}{*}{$\begin{array}{c}\text { Flow Unit } \\
\text { Sample } \\
\text { (Interval in cm) } \\
\text { Plotting Symbol }\end{array}$} & \multirow{2}{*}{$\begin{array}{c}1 \mathrm{~B} \\
31-1 \\
115.5-117.5 \\
\mathrm{~A}\end{array}$} & \multicolumn{4}{|c|}{2} & \multicolumn{2}{|c|}{3} & \multirow{2}{*}{$\begin{array}{c}4 \\
32-4 \\
59-61 \\
H\end{array}$} & \multirow{2}{*}{$\begin{array}{c}5 \mathrm{~A} \\
33-1, \\
116.5-118.5 \\
\mathrm{I}\end{array}$} & \multirow{2}{*}{$\begin{array}{c}6 \\
34-1, \\
73.5-75.5 \\
\mathrm{~J}\end{array}$} \\
\hline & & $\begin{array}{c}32-1, \\
141.5-143.5 \\
\text { B }\end{array}$ & $\begin{array}{c}32-2 \\
82.5-83.5 \\
\text { C }\end{array}$ & $\begin{array}{c}32-2 \\
96-105 \\
\text { D }\end{array}$ & $\begin{array}{c}32-2, \\
96-105 \\
E\end{array}$ & $\begin{array}{c}32-3, \\
9.5-11.5 \\
F\end{array}$ & $\begin{array}{c}32-3, \\
87.5-89.5 \\
G\end{array}$ & & & \\
\hline $\mathrm{SiO}_{2}$ & 48.71 & 49.56 & 48.89 & 48.01 & 48.01 & 48.84 & 48.56 & 28.63 & 48.39 & 48.72 \\
\hline $\mathrm{Al}_{2} \mathrm{O}_{3}$ & 16.59 & 15.81 & 15.63 & 15.39 & 15.57 & 15.51 & 16.82 & 16.06 & 15.99 & 15.78 \\
\hline "FeO"c & 12.12 & 13.08 & 13.01 & 13.64 & 13.24 & 13.06 & 12.24 & 12.85 & 13.44 & 13.51 \\
\hline $\mathrm{MgO}$ & 7.75 & 7.52 & 7.05 & 7.26 & 7.66 & 7.61 & 7.90 & 8.07 & 8.19 & 7.75 \\
\hline $\mathrm{CaO}$ & 7.58 & 6.48 & 7.32 & 7.55 & 7.16 & 7.10 & 7.56 & 7.95 & 6.47 & 6.20 \\
\hline $\mathrm{Na}_{2} \mathrm{O}$ & 3.43 & 3.59 & 3.68 & 3.61 & 3.67 & 3.48 & 3.32 & 3.03 & 3.54 & 3.54 \\
\hline $\mathrm{K}_{2} \mathrm{O}$ & 0.34 & 0.43 & 0.52 & 0.45 & 0.49 & 0.48 & 0.38 & 0.28 & 0.50 & 0.55 \\
\hline $\mathrm{TiO}_{2}$ & 2.50 & 2.75 & 3.15 & 3.15 & 3.15 & 2.97 & 2.40 & 2.42 & 2.74 & 3.13 \\
\hline $\mathrm{P}_{2} \mathrm{O}_{5}$ & 0.33 & 0.33 & 0.35 & 0.32 & 0.35 & 0.33 & 0.27 & 0.32 & 0.32 & 0.35 \\
\hline $\mathrm{MnO}$ & 0.50 & 0.37 & 0.36 & 0.43 & 0.43 & 0.42 & 0.36 & 0.26 & 0.27 & 0.39 \\
\hline S & 0.12 & 0.06 & 0.04 & 0.17 & 0.21 & 0.18 & 0.15 & 0.11 & 0.13 & 0.06 \\
\hline $\mathrm{Cr}_{2} \mathrm{O}_{3}$ & 0.02 & 0.02 & 0.02 & 0.01 & 0.03 & 0.01 & 0.02 & 0.02 & 0.02 & 0.01 \\
\hline $\mathrm{NiO}$ & 0.01 & 0.01 & 0.01 & 0.01 & 0.01 & 0.01 & 0.01 & 0.01 & 0.01 & 0.01 \\
\hline Total & 100.00 & 100.01 & 100.03 & 100.00 & 99.98 & 100.00 & 99.99 & 100.01 & 100.01 & 100.00 \\
\hline \multicolumn{11}{|l|}{$Q$} \\
\hline Or & 2.009 & 2.541 & 3.072 & 2.659 & 2.896 & 2.836 & 2.246 & 1.654 & 2.954 & 3.250 \\
\hline $\mathrm{Ab}$ & 29.024 & 30.375 & 31.130 & 30.547 & 31.061 & 29.447 & 28.096 & 25.636 & 29.952 & 29.954 \\
\hline An & 28.867 & 25.752 & 24.586 & 24.459 & 24.568 & 25.282 & 29.873 & 29.390 & 26.261 & 25.542 \\
\hline \multicolumn{11}{|l|}{$\begin{array}{l}\mathrm{Ne} \\
\mathrm{Ns}\end{array}$} \\
\hline Wo & 2.748 & 1.769 & 3.938 & 4.553 & 3.621 & 3.251 & 2.452 & 3.322 & 1.563 & 1.223 \\
\hline En & 6.732 & 8.886 & 5.808 & 4.208 & 4.069 & 7.588 & 6.644 & 9.506 & 5.667 & 7.380 \\
\hline Fs & 6.561 & 9.510 & 6.376 & 4.726 & 4.153 & 7.806 & 6.374 & 9.392 & 5.665 & 7.743 \\
\hline Fo & 8.808 & 6.896 & 8.230 & 9.722 & 10.520 & 7.964 & 9.133 & 7.422 & 10.321 & 8.354 \\
\hline $\mathrm{Fa}$ & 9.461 & 8.133 & 9.958 & 12.031 & 11.832 & 9.029 & 9.656 & 8.081 & 11.370 & 9.659 \\
\hline \multicolumn{11}{|c|}{ 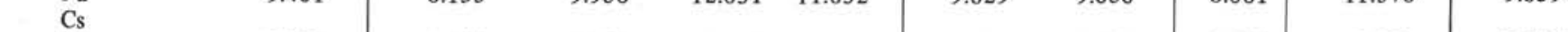 } \\
\hline $\mathrm{Cm}$ & 0.029 & 0.029 & 0.029 & 0.015 & 0.044 & 0.015 & 0.029 & 0.029 & 0.029 & 0.015 \\
\hline II & 4.748 & 5.222 & 5.981 & 5.983 & 5.984 & 5.641 & 4.559 & 4.596 & 5.203 & 5.945 \\
\hline Ap & 0.782 & 0.782 & 0.829 & 0.758 & 0.829 & 0.782 & 0.640 & 0.758 & 0.758 & 0.829 \\
\hline $\operatorname{Pr}$ & 0.225 & 0.112 & 0.075 & 0.318 & 0.393 & 0.337 & 0.281 & 0.206 & 0.243 & 0.112 \\
\hline Total & 99.993 & 100.006 & 100.012 & 99.979 & 99.971 & 99.977 & 99.981 & 99.992 & 99.987 & 100.008 \\
\hline
\end{tabular}

${ }^{\mathrm{a} C a l c u l a t e d}$ from Tables 5 and 8.

bee Figures 15-17.

" $\mathrm{FeO}$ " is $\mathrm{FeO}+0.9 \mathrm{Fe}_{2} \mathrm{O}_{3}$ after summing to $100 \%$ dry weight. 
TABLE 14

Dry Reduced Chemical Analyses and Norms of Basalts From Hole $317 \mathrm{~A}^{\mathrm{a}}$

\begin{tabular}{|c|c|c|c|c|c|c|c|c|c|c|c|}
\hline \multirow{2}{*}{$\begin{array}{c}\text { Flow Unit } \\
\text { Sample } \\
\text { (Interval in cm) } \\
\text { Plotting Symbolb }\end{array}$} & \multirow{2}{*}{$\begin{array}{c}1 \\
31-1 \\
\begin{array}{c}144-146 \\
\text { A }\end{array}\end{array}$} & \multirow{2}{*}{$\begin{array}{c}2 \\
31-2, \\
37-39 \\
\text { B }\end{array}$} & \multirow{2}{*}{$\begin{array}{c}3 \\
31-3 \\
27-29 \\
C\end{array}$} & \multirow{2}{*}{\begin{tabular}{|c|}
4 \\
$31-3$ \\
$100-103$ \\
$D$
\end{tabular}} & \multirow{2}{*}{$\begin{array}{c}5 \mathrm{~A} \\
31-4 \\
80-82 \\
\mathrm{E}\end{array}$} & \multicolumn{6}{|c|}{ 5B } \\
\hline & & & & & & $\begin{array}{c}32-1 \\
84-86 \\
F\end{array}$ & $\begin{array}{c}32-2 \\
75-77 \\
\text { G }\end{array}$ & 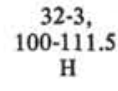 & $\begin{array}{c}32-3 \\
100-111.3 \\
1\end{array}$ & $\begin{array}{c}32-3 \\
106-108 \\
\mathrm{~J}\end{array}$ & $\begin{array}{c}32-4 \\
76-78 \\
K\end{array}$ \\
\hline $\mathrm{SiO}_{2}$ & 50.57 & 50.59 & 50.59 & 50.75 & 51.18 & 51.08 & 51.62 & 51.33 & 51.51 & 51.58 & 51.35 \\
\hline $\mathrm{Al}_{2} \mathrm{O}_{3}$ & 14.62 & 14.52 & 15.63 & 15.33 & 15.78 & 15.65 & 15.52 & 15.47 & 15.27 & 14.99 & 15.15 \\
\hline "FeO"c & 10.76 & 10.80 & 9.27 & 9.44 & 9.39 & 10.21 & 10.53 & 11.08 & 11.08 & 11.29 & 10.81 \\
\hline $\mathrm{MgO}$ & 10.33 & 10.50 & 9.32 & 9.28 & 8.49 & 8.00 & 7.45 & 7.15 & 7.10 & 7.28 & 7.59 \\
\hline $\mathrm{CaO}$ & 9.89 & 9.70 & 11.48 & 11.64 & 11.49 & 11.60 & 11.14 & 11.41 & 11.56 & 11.15 & 11.27 \\
\hline $\mathrm{Na}_{2} \mathrm{O}$ & 2.27 & 2.41 & 2.17 & 2.16 & 2.17 & 2.06 & 2.15 & 2.11 & 2.05 & 2.20 & 2.30 \\
\hline $\mathrm{K}_{2} \mathrm{O}$ & 0.04 & 0.04 & 0.05 & 0.02 & 0.09 & 0.02 & 0.12 & 0.12 & 0.09 & 0.11 & 0.06 \\
\hline $\mathrm{TiO}_{2}$ & 1.07 & 0.98 & 0.94 & 0.89 & 0.98 & 0.96 & 1.04 & 1.01 & 1.02 & 1.04 & 1.06 \\
\hline $\mathrm{P}_{2} \mathrm{O}_{5}$ & 0.13 & 0.14 & 0.13 & 0.14 & 0.13 & 0.13 & 0.14 & 0.08 & 0.10 & 0.13 & 0.12 \\
\hline $\mathrm{MnO}$ & 0.27 & 0.25 & 0.34 & 0.25 & 0.28 & 0.24 & 0.25 & 0.19 & 0.19 & 0.18 & 0.25 \\
\hline S & 0.02 & 0.01 & 0.01 & 0.01 & 0.01 & 0.01 & 0.01 & & 0.01 & 0.01 & 0.01 \\
\hline $\mathrm{Cr}_{2} \mathrm{O}_{3}$ & 0.03 & 0.04 & 0.06 & 0.07 & 0.03 & 0.04 & 0.03 & 0.03 & 0.02 & 0.02 & 0.02 \\
\hline $\mathrm{NiO}$ & 0.01 & 0.01 & 0.02 & 0.01 & 0.01 & 0.01 & 0.01 & 0.01 & 0.01 & 0.01 & 0.01 \\
\hline Total & 100.01 & 99.99 & 100.01 & 99.99 & 100.03 & 100.01 & 100.01 & 99.99 & 99.99 & 99.99 & 99.99 \\
\hline$Q$ & & & & & & & 0.605 & 0.170 & 0.827 & 0.315 & \\
\hline Or & 0.236 & 0.236 & 0.295 & 0.118 & 0.532 & 0.118 & 0.709 & 0.709 & 0.532 & 0.650 & 0.355 \\
\hline$A b$ & 19.206 & 20.395 & 18.360 & 18.279 & 18.356 & 17.429 & 18.191 & 17.856 & 17.348 & 18.618 & 19.464 \\
\hline An & 29.581 & 28.686 & 32.756 & 32.078 & 33.041 & 33.393 & 32.339 & 32.389 & 32.201 & 30.704 & 30.840 \\
\hline \multirow{2}{*}{\multicolumn{12}{|c|}{$\begin{array}{l}\mathrm{Ne} \\
\mathrm{Ns}\end{array}$}} \\
\hline & & & & & & & & & & & \\
\hline Wo & 7.778 & 7.735 & 9.746 & 10.338 & 9.643 & 9.729 & 9.189 & 9.895 & 10.230 & 9.924 & 10.143 \\
\hline En & 18.404 & 17.245 & 17.468 & 18.040 & 18.927 & 19.195 & 18.552 & 17.809 & 17.684 & 18.133 & 17.777 \\
\hline Fs & 13.194 & 12.293 & 12.090 & 12.697 & 14.426 & 16.929 & 18.053 & 19.025 & 18.960 & 19.331 & 17.456 \\
\hline Fo & 5.130 & 6.242 & 4.023 & 3.556 & 1.550 & 0.509 & & & & & 0.790 \\
\hline $\mathrm{Fa}$ & 4.053 & 4.904 & 3.069 & 2.758 & 1.302 & 0.495 & & & & & 0.855 \\
\hline \multicolumn{12}{|l|}{ Cs } \\
\hline $\mathrm{Cm}$ & 0.044 & 0.059 & 0.088 & 0.103 & 0.044 & 0.059 & 0.044 & 0.044 & 0.029 & 0.029 & 0.029 \\
\hline II & 2.032 & 1.861 & 1.785 & 1.690 & 1.861 & 1.823 & 1.975 & 1.918 & 1.937 & 1.975 & 1.994 \\
\hline Ap & 0.308 & 0.332 & 0.308 & 0.332 & 0.308 & 0.308 & 0.332 & 0.190 & 0.237 & 0.308 & 0.284 \\
\hline Pr & 0.037 & 0.019 & 0.019 & 0.019 & 0.019 & 0.019 & 0.019 & & 0.019 & 0.019 & 0.019 \\
\hline Total & 100.005 & 100.007 & 100.008 & 100.007 & 100.007 & 100.007 & 100.007 & 100.006 & 100.005 & 100.006 & 100.006 \\
\hline \multirow{3}{*}{$\begin{array}{c}\text { Flow Unit } \\
\text { Sample } \\
\text { (Interval in cm) } \\
\text { Plotting Symbol b }\end{array}$} & & $6 \mathrm{~A}$ & & & $6 \mathrm{~B}$ & & $7 \mathrm{~A}$ & $7 \mathrm{~B}$ & 9 & 10 & \\
\hline & $\begin{array}{c}32-4, \\
126-128\end{array}$ & $\begin{array}{l}32-5 \text {, } \\
95-97\end{array}$ & $\begin{array}{c}32-6 \\
113-115\end{array}$ & $\begin{array}{c}33-1 \\
138-140\end{array}$ & $\begin{array}{l}33-2 \\
82-84\end{array}$ & $\begin{array}{l}33-3 \text {, } \\
94-96\end{array}$ & $\begin{array}{c}33-4, \\
103-105\end{array}$ & $\begin{array}{r}34-1 \\
40-41\end{array}$ & $\begin{array}{l}34-2 \\
91-93\end{array}$ & $\begin{array}{l}34-3, \\
118-120\end{array}$ & $\begin{array}{l}34-4 \\
65-67\end{array}$ \\
\hline & L & M & N & 0 & P & Q & R & $\mathrm{S}$ & $\mathrm{T}$ & $\mathrm{U}$ & V \\
\hline $\mathrm{SiO}_{2}$ & 50.42 & 50.81 & 50.74 & 50.91 & 50.68 & 50.53 & 51.38 & 51.25 & 51.98 & 51.89 & 51.38 \\
\hline $\mathrm{Al}_{2} \mathrm{O}_{3}$ & 14.47 & 13.87 & 13.53 & 13.62 & 14.44 & 15.43 & 15.36 & 15.19 & 15.28 & 14.60 & 15.51 \\
\hline "FeO"c & 10.01 & 9.51 & 10.16 & 10.26 & 10.31 & 10.07 & 9.51 & 9.69 & 9.30 & 10.65 & 9.95 \\
\hline $\mathrm{MgO}$ & 9.44 & 10.13 & 10.12 & 9.46 & 8.88 & 8.88 & 8.47 & 8.28 & 7.77 & 7.68 & 7.50 \\
\hline $\mathrm{CaO}$ & 12.41 & 12.42 & 12.30 & 12.59 & 12.42 & 11.45 & 10.99 & 11.68 & 11.50 & 11.01 & 11.81 \\
\hline $\mathrm{Na}_{2} \mathrm{O}$ & 1.91 & 1.81 & 1.78 & 1.88 & 1.93 & 2.25 & 2.39 & 2.28 & 2.34 & 2.44 & 2.25 \\
\hline $\mathrm{K}_{2} \mathrm{O}$ & 0.04 & 0.04 & 0.02 & 0.07 & 0.04 & 0.13 & 0.26 & 0.06 & 0.25 & 0.15 & 0.10 \\
\hline $\mathrm{TiO}_{2}$ & 0.85 & 0.85 & 0.84 & 0.85 & 0.91 & 0.94 & 1.12 & 1.05 & 1.11 & 1.18 & 1.09 \\
\hline $\mathrm{P}_{2} \mathrm{O}_{5}$ & 0.12 & 0.13 & 0.13 & 0.12 & 0.11 & 0.13 & 0.18 & 0.17 & 0.17 & 0.16 & 0.13 \\
\hline $\mathrm{MnO}$ & 0.20 & 0.26 & 0.26 & 0.14 & 0.18 & 0.14 & 0.27 & 0.27 & 0.24 & 0.14 & 0.19 \\
\hline $\mathrm{S}$ & 0.01 & 0.01 & 0.02 & 0.01 & 0.01 & 0.01 & 0.02 & 0.01 & 0.01 & 0.01 & 0.01 \\
\hline $\mathrm{Cr}_{2} \mathrm{O}_{3}$ & 0.09 & 0.14 & 0.09 & 0.08 & 0.07 & 0.05 & 0.05 & 0.06 & 0.06 & 0.06 & 0.05 \\
\hline $\mathrm{NiO}$ & 0.02 & 0.02 & 0.01 & 0.01 & 0.01 & 0.01 & 0.01 & 0.01 & 0.01 & 0.01 & 0.01 \\
\hline Total & 99.99 & 100.00 & 100.00 & 100.00 & 99.99 & 100.02 & 100.01 & 99.98 & 100.02 & 99.98 & 99.98 \\
\hline Q & & & & & & & & & 0.052 & & \\
\hline Or & 0.236 & 0.236 & 0.118 & 0.414 & 0.236 & 0.768 & 1.536 & 0.355 & 1.477 & 0.887 & 0.591 \\
\hline $\mathrm{Ab}$ & 16.163 & 15.316 & 15.062 & 15.908 & 16.333 & 19.035 & 20.221 & 19.297 & 19.796 & 20.651 & 19.043 \\
\hline An & 30.794 & 29.603 & 28.869 & 28.518 & 30.622 & 31.612 & 30.412 & 31.042 & 30.445 & 28.447 & 31.932 \\
\hline $\mathrm{Ne}$ & & & & & & & & & & & \\
\hline Ns & & & & & & & & & & & \\
\hline Wo & 12.524 & 13.012 & 13.070 & 13.845 & 12.643 & 10.159 & 9.573 & 10.774 & 10.641 & 10.496 & 10.781 \\
\hline En & 18.020 & 20.822 & 20.750 & 19.516 & 18.460 & 15.775 & 17.833 & 18.401 & 19.347 & 18.838 & 18.136 \\
\hline Fs & 13.250 & 13.565 & 14.532 & 14.599 & 14.775 & 12.235 & 13.568 & 14.765 & 15.633 & 17.544 & 16.291 \\
\hline Fo & 3.849 & 3.088 & 3.121 & 2.834 & 2.563 & 4.440 & 2.284 & 1.524 & & 0.205 & 0.383 \\
\hline $\mathrm{Fa}$ & 3.119 & 2.217 & 2.409 & 2.336 & 2.261 & 3.795 & 1.915 & 1.348 & & 0.211 & 0.379 \\
\hline Cs & & & & & & & & & & & \\
\hline $\mathrm{Cm}$ & 0.133 & 0.206 & 0.133 & 0.118 & 0.103 & 0.074 & 0.074 & 0.088 & 0.088 & 0.088 & 0.074 \\
\hline Il & 1.614 & 1.614 & 1.595 & 1.614 & 1.728 & 1.785 & 2.127 & 1.995 & 2.108 & 2.242 & 2.071 \\
\hline Ap & 0.284 & 0.308 & 0.308 & 0.284 & 0.261 & 0.308 & 0.426 & 0.403 & 0.403 & 0.379 & 0.308 \\
\hline $\mathrm{Pr}$ & 0.019 & 0.019 & 0.037 & 0.019 & 0.019 & 0.019 & 0.037 & 0.019 & 0.019 & 0.019 & 0.019 \\
\hline Total & 100.005 & 100.007 & 100.004 & 100.005 & 100.005 & 100.005 & 100.007 & 100.009 & 100.009 & 100.007 & 100.006 \\
\hline
\end{tabular}

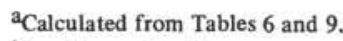

$b_{\text {See Figures 18-20. }}$

c" $\mathrm{FeO}$ " is $\mathrm{FeO}$ plus $0.9 \mathrm{Fe}_{2} \mathrm{O}_{3}$ after summing to $100 \%$ dry weight. 

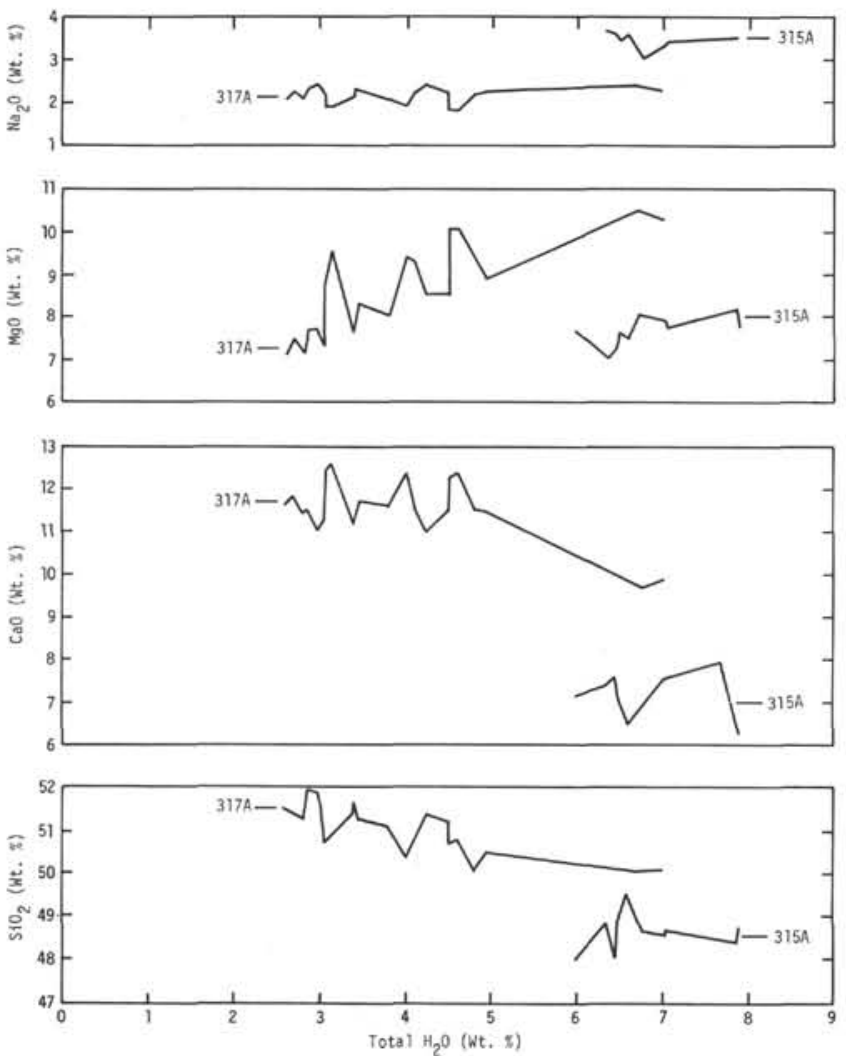

Figure 6. Variation of $\mathrm{SiO}_{2}, \mathrm{CaO}, \mathrm{MgO}$, and $\mathrm{Na}_{2} \mathrm{O}$, with total $\mathrm{H}_{2} \mathrm{O}$ content of basalts from Holes $315 \mathrm{~A}$ and $317 \mathrm{~A}$. (Oxides are dry, reduced, normalized.)

island type, capped the ridge. Schilling (1973) and Moore and Schilling (1973) have carefully examined a suite of basalts from the Reykjanes Ridge, over a distance equivalent to $5^{\circ}$ in latitude and onto Iceland proper. The basalts gradually change in minor-element content, vesicle size, and vesicle abundance from purely oceanic ridge values at the south end of the ridge to oceanic island type materials on subaerial Iceland. $\mathrm{K}_{2} \mathrm{O}$, $\mathrm{TiO}_{2}, \mathrm{P}_{2} \mathrm{O}_{5}$, and rare-earth behavior patterns of these basalts do not compare with Hawaiian patterns until subaerial rocks are analyzed. Even at the margins of Iceland itself, Schilling (1973) gives $\mathrm{P}_{2} \mathrm{O}_{5}$ values of $0.18 \%-0.26 \%, \mathrm{~K}_{2} \mathrm{O}$ values of $0.16 \%-0.26 \%$, and $\mathrm{TiO}_{2}$ values of $1.4 \%-2.1 \%$. The range of these constituents in Hole $315 \mathrm{~A}$ basalts is $0.27 \%-0.35 \%, 0.28 \%-0.55 \%$, and $2.4 \%-3.15 \%$, respectively. By an Iceland analogy, the entire Line Islands between at least Sites 165 and 316 would be expected to have been subaerial some $80-90$ m.y. B.P. Moore and Schilling (1973) show that vesicle volumes exceed $40 \%$ at water depths as shallow as 100 meters. The vesicles in basalts at Site 165A (Bass et al., 1973) range from absent to $3.0 \%$, average $1.0 \%$, and are small. The vesicles in the Hole $315 \mathrm{~A}$ basalts range from $1.5 \%$ to $9.5 \%$, average $5.0 \%$, and are small. These vesicles suggest that the Hole $315 \mathrm{~A}$ basalts crystallized at depths of 1000-3000 meters beneath sea level, although Hays and Pitman (1973) reported water depths were up to 500 meters deeper $80-90$ m.y. B.P. than at present, so that the area could have subsided somewhat

TABLE 15

Range and Average Abundance of Oxides and Elements in Basalts from Holes 315A and 317A

\begin{tabular}{|c|c|c|c|c|}
\hline \multirow{2}{*}{\multicolumn{3}{|c|}{ Hole $315 \mathrm{~A}$}} & \multicolumn{2}{|c|}{ Hole $317 \mathrm{~A}$} \\
\hline & & Average & Range & Average \\
\hline \multicolumn{5}{|c|}{ Oxide (\%) } \\
\hline $\mathrm{SiO}_{2}$ & $44.41-45.95$ & $45.03^{\mathrm{a}}$ & $46.79-50.42$ & $48.99^{b}$ \\
\hline $\mathrm{Al}_{2} \mathrm{O}_{3}$ & $14.27-15.57$ & $14.74^{\mathrm{a}}$ & $12.88-15.17$ & $14.35^{\mathrm{b}}$ \\
\hline $\mathrm{Fe}_{2} \mathrm{O}_{3}$ & $5.88-8.56$ & $6.96^{\mathrm{a}}$ & $0.85-5.56$ & $4.11^{\mathrm{b}}$ \\
\hline $\mathrm{FeO}$ & $4.17-7.03$ & $5.79^{\mathrm{a}}$ & $4.80-8.31$ & $6.06^{\mathrm{b}}$ \\
\hline $\mathrm{MgO}$ & $6.52-7.57$ & $7.11^{\mathrm{a}}$ & $6.87-9.71$ & $8.23^{\mathrm{b}}$ \\
\hline $\mathrm{CaO}$ & $5.61-7.46$ & $6.60^{\mathrm{a}}$ & $8.97-12.18$ & $11.02^{\mathrm{b}}$ \\
\hline $\mathrm{Na}_{2} \mathrm{O}$ & $2.84-3.41$ & $3.24^{\mathrm{a}}$ & $1.69-2.37$ & $2.06^{\mathrm{b}}$ \\
\hline $\mathrm{K}_{2} \mathrm{O}$ & $0.26-0.50$ & $0.41^{\mathrm{a}}$ & $0.02-0.25$ & $0.09^{b}$ \\
\hline $\mathrm{H}_{2} \mathrm{O}^{+}$ & $1.36-3.56$ & $2.57^{\mathrm{a}}$ & $0.72-2.14$ & $1.54^{\mathrm{b}}$ \\
\hline $\mathrm{H}_{2} \mathrm{O}^{-}$ & $3.20-5.26$ & $4.27^{\mathrm{a}}$ & $1.54-5.06$ & $2.40^{\mathrm{b}}$ \\
\hline $\mathrm{TiO}_{2}$ & $2.22-2.93$ & $2.62^{\mathrm{a}}$ & $0.80-1.15$ & $0.95^{\mathrm{b}}$ \\
\hline $\mathrm{P}_{2} \mathrm{O}_{3}$ & $0.25-0.33$ & $0.30^{\mathrm{a}}$ & $0.08-0.17$ & $0.13^{\mathrm{b}}$ \\
\hline $\mathrm{MnO}$ & $0.24-0.46$ & $0.35^{\mathrm{a}}$ & $0.13-0.32$ & $0.22^{\mathrm{b}}$ \\
\hline \multicolumn{5}{|c|}{ Element (ppm) } \\
\hline $\mathrm{Ba}$ & $92-144$ & $117^{\mathrm{a}}$ & $<22-<22$ & $<22^{\mathrm{b}}$ \\
\hline $\mathrm{C}$ & $100-1200$ & $400^{\mathrm{a}}$ & $<0.01-0.02$ & $0.01^{\mathrm{b}}$ \\
\hline $\mathrm{Ce}$ & $29.4-38.1$ & $34.4^{\mathrm{e}}$ & $<5-11.9$ & $7^{\mathrm{f}}$ \\
\hline $\mathrm{Cl}$ & $50-600$ & $120^{\mathrm{a}}$ & $50-1100$ & $371^{\mathrm{b}}$ \\
\hline Co & $43.5-55.9$ & $49.3^{\mathrm{e}}$ & $41.1-51.3$ & $47.4^{\mathrm{f}}$ \\
\hline $\mathrm{Cr}$ & $205-205$ & $205^{\mathrm{a}}$ & $<205-<205$ & $<205^{b}$ \\
\hline $\mathrm{Cr}$ & $61-145$ & $108^{\mathrm{c}}$ & $130-920$ & $360^{\mathrm{d}}$ \\
\hline $\mathrm{Cr}$ & $75-174$ & $121^{\mathrm{e}}$ & $125-683$ & $373^{f}$ \\
\hline Cs & $<1 \cdot<1$ & $<1^{\mathrm{e}}$ & $<1-<1$ & $<1^{\mathrm{f}}$ \\
\hline $\mathrm{Eu}$ & $1.90-2.29$ & $2.09^{\mathrm{e}}$ & $0.70-1.03$ & $0.85^{\mathrm{f}}$ \\
\hline Gd & $3.6-8.2$ & $5.6^{\mathrm{e}}$ & $<6-<6$ & $<6^{\mathrm{f}}$ \\
\hline $\mathrm{Hf}$ & $3.7-4.9$ & $4.4^{e}$ & $0.9-1.7$ & $1.3^{\mathrm{f}}$ \\
\hline $\mathrm{Nb}$ & $32-44$ & $38^{\mathrm{c}}$ & $\mathrm{N} 15^{\mathrm{g}}-\mathrm{N} 15$ & $\mathrm{~N} 15^{\mathrm{d}}$ \\
\hline $\mathrm{Ni}$ & $38-92$ & $66^{\mathrm{c}}$ & $60-120$ & $82^{\mathrm{d}}$ \\
\hline $\mathrm{Ni}$ & $63-63$ & $63^{a}$ & $79-79$ & $79^{b}$ \\
\hline $\mathrm{Rb}$ & $<12-<12$ & $<12^{\mathrm{a}}$ & $<12-<12$ & $<12^{\mathrm{b}}$ \\
\hline S & $320-2000$ & $1100^{\mathrm{a}}$ & $0-150$ & $102^{\mathrm{b}}$ \\
\hline $\mathrm{Sc}$ & $25.9-34.4$ & $29.9^{\mathrm{e}}$ & $40.4-48.4$ & $44.1^{\mathrm{f}}$ \\
\hline $\mathrm{Sr}$ & $237-275$ & $249^{\mathrm{a}}$ & $81-118$ & $100^{\mathrm{b}}$ \\
\hline $\mathrm{Ta}$ & $1.2-1.5$ & $1.3^{\mathrm{e}}$ & $0.2-0.3$ & $0.3^{\mathrm{f}}$ \\
\hline $\mathrm{Tb}$ & $1.0-1.2$ & $1.1^{\mathrm{e}}$ & $0.4-0.6$ & $0.5^{f}$ \\
\hline $\mathrm{Th}$ & $1.2-2.0$ & $1.5^{\mathrm{e}}$ & $<1.5-<1.7$ & $<1.6^{\mathrm{f}}$ \\
\hline $\mathrm{U}$ & $<0.1-0.4$ & $0.2^{\mathrm{e}}$ & $<0.1-0.1$ & $<0.1^{\mathrm{f}}$ \\
\hline V & $170-280$ & $235^{\mathrm{c}}$ & $125-240$ & $201^{\mathrm{d}}$ \\
\hline $\mathrm{Y}$ & $39-60$ & $50^{\mathrm{c}}$ & $14-34$ & $24^{\mathrm{d}}$ \\
\hline $\mathrm{Yb}$ & $2.9-3.9$ & $3.4^{\mathrm{e}}$ & $1.7-2.6$ & $2.2^{\mathrm{f}}$ \\
\hline $\mathrm{Zn}$ & $100-140$ & $118^{\mathrm{e}}$ & $<16-<20$ & $<20^{\mathrm{f}}$ \\
\hline $\mathrm{Zr}$ & $165-230$ & $192^{\mathrm{c}}$ & $45-92$ & $72^{\mathrm{d}}$ \\
\hline $\mathrm{Zr}$ & $120-<200$ & $188^{\mathrm{e}}$ & $<200-<200$ & $<200^{\mathrm{f}}$ \\
\hline
\end{tabular}

${ }^{\text {a}}$ From Table 3, this report.

${ }^{b}$ From Table 4, this report.

${ }^{c}$ From Table 6, this report.

$\mathrm{d}_{\text {From Table }}$, this report.
eFrom Table 8, this report.

f From Table 9, this report.

$\mathrm{g}_{\mathrm{N}}$ Not detected at value shown. 


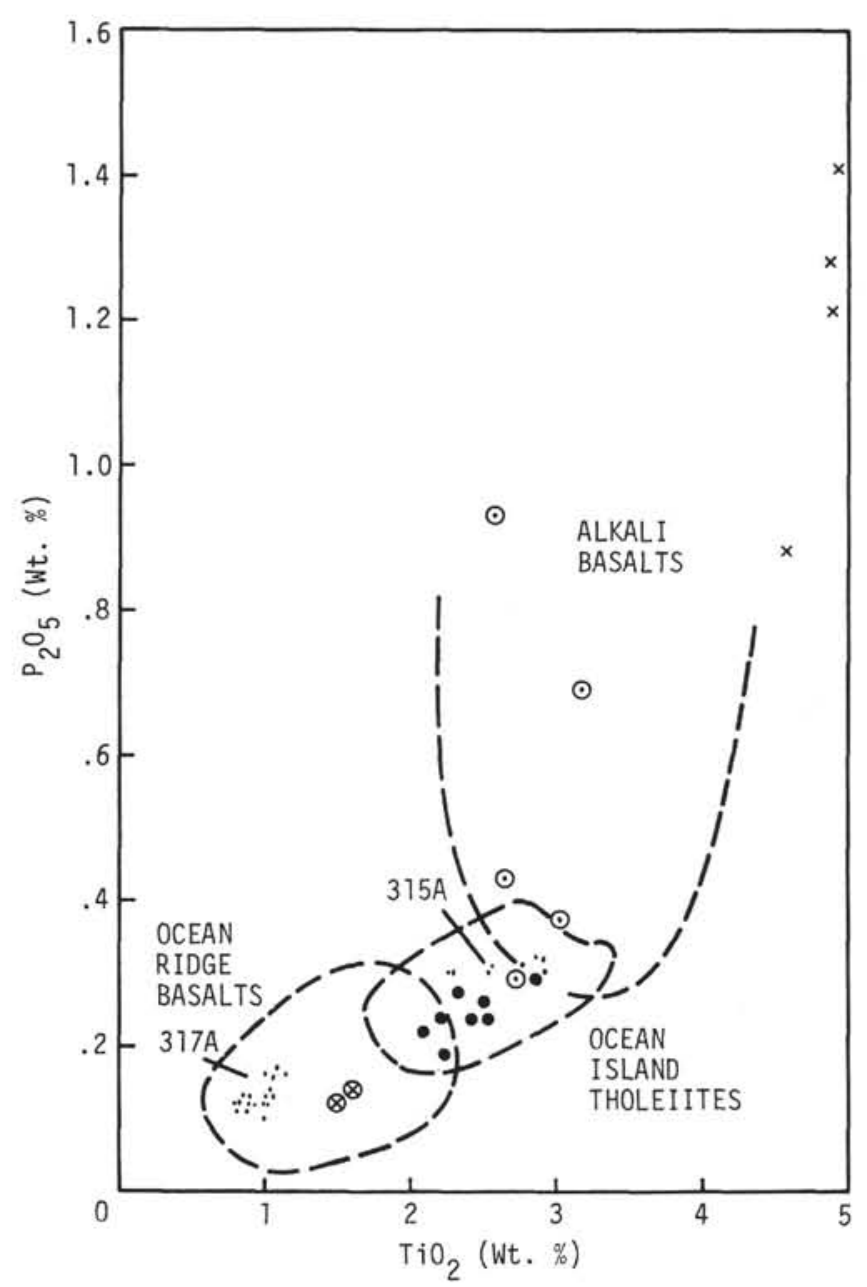

Figure 7. $\mathrm{TiO}_{2}$ versus $\mathrm{P}_{2} \mathrm{O}_{5}$ diagram comparing $\mathrm{Leg} 33 \mathrm{ba}$ salts with basalts from DSDP Legs 17 (Hole 165A) and 30 (Hole 289), and average Hawaiian tholeiites and alkalic basalts. (Crosses, as well as basalt fields are from Bass et al., 1973; average Hawaiian tholeiites solid circles and alkalic basalts open circles from Macdonald and Katsura, 1964, Tables 9 and 10; Circled crosses from Stoeser, in press; and small dots, Leg 33, Holes $315 \mathrm{~A}$ and $317 \mathrm{~A}$ from Tables 5 and 6, this report.)

since the crystallization of the basalts. In addition, the present bathymetry of the Line Islands bears little resemblance to a sunken Iceland.

The variety of oceanic island rock types in the breccia beds of Hole 318 suggest that these were derived from local Tuamotu edifices, and that the basaltic character of these islands is of the oceanic island basalt type. Age data further southeast along the Tuamotus are so scanty it is presently impossible to say whether or not these islands are edifices of a propagating chain.

\section{REFERENCES}

Andrews, J.E., Packham, G., et al., in press. Initial Reports of the Deep Sea Drilling Project, Volume 30: Washington (U.S. Government Printing Office).

Aumento, F., 1968. The mid-Atlantic ridge near $45^{\circ} \mathrm{N}$. II. Basalts from the area of Confederation peak: Canadian J. Earth Sci., v. 5, p. 1-21.

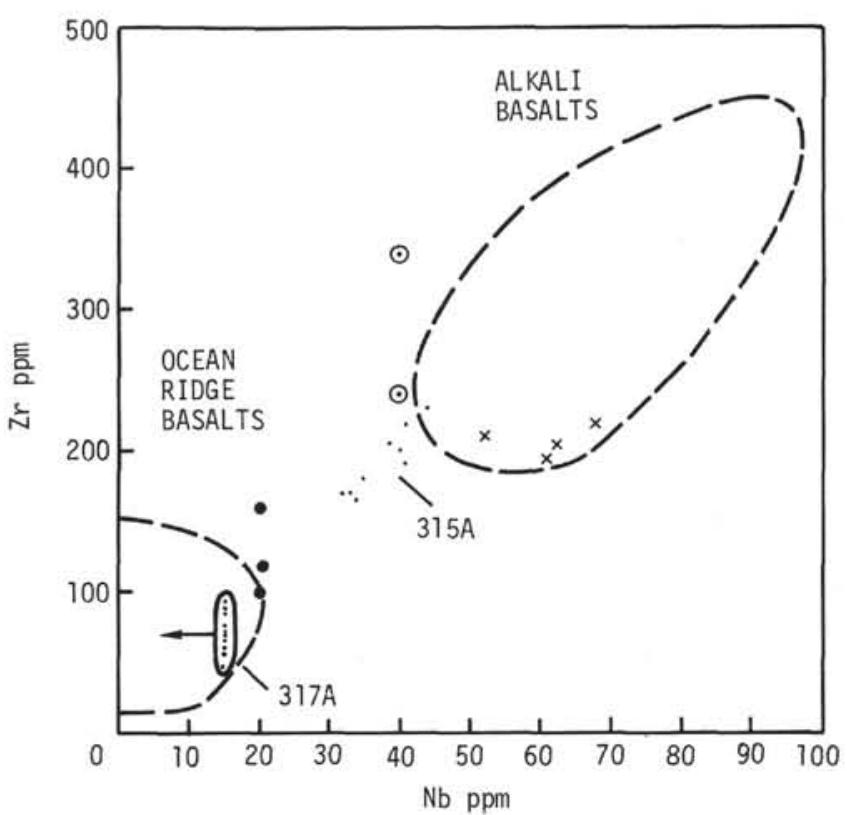

Figure 8. $\mathrm{Zr}$ : $\mathrm{Nb}$ diagram comparing Leg 33 basalts with basalts from DSDP Leg 17 (Hole 165A) and the Hawaiian Islands. (Crosses and field boundaries are from Bass et al., 1973; Hawaiian tholeiites, solid circles, and alkalic basalts, open circles, from Hubbard, 1967; and, dots, Leg 33, Holes $315 \mathrm{~A}$ and $317 \mathrm{~A}$ from Tables 8 and 9 , this report.)

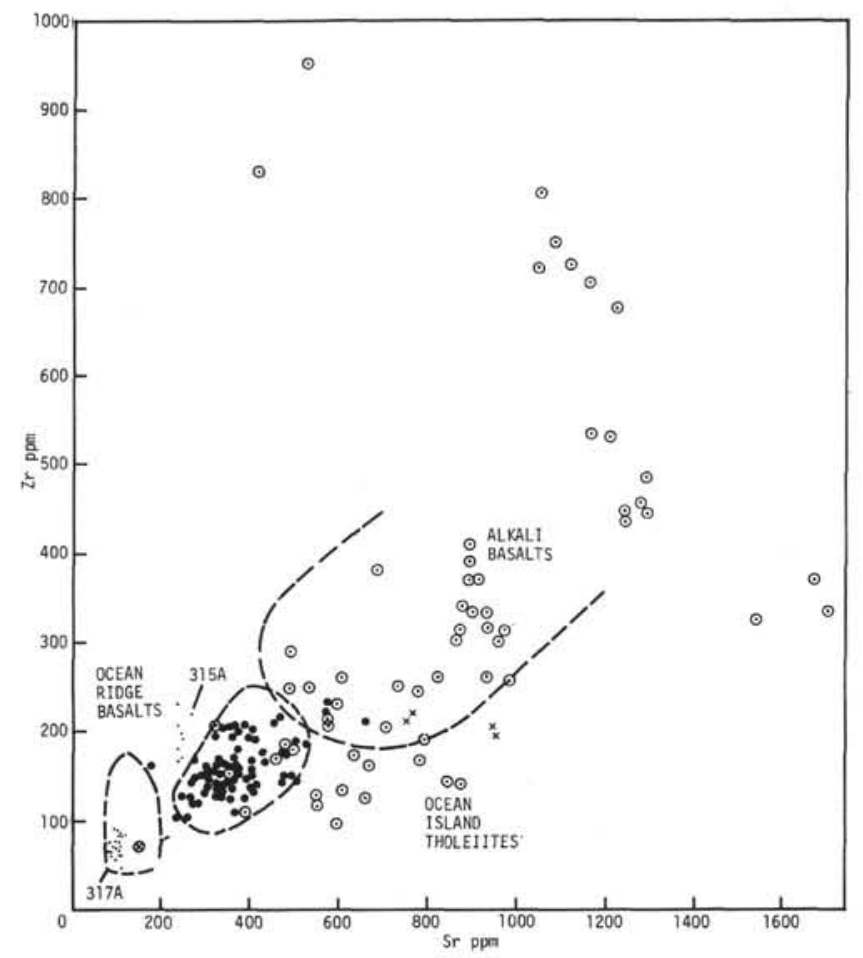

Figure 9. Zr: Sr diagram comparing Leg 33 basalts with basalts from DSDP Legs 17 (Hole 165A) and 30 (289), and the Hawaiian Islands. (Crosses and field boundaries are from Bass et al., 1973; circled cross, from Stoeser, in press; Hawaiian tholeiites, solid circles and alkalic basalts, open circles, from Hubbard, 1967; and dots, Leg 33, Holes $315 A$ and $317 A$ are from Tables 5, 6, 8, and 9, this report.) 


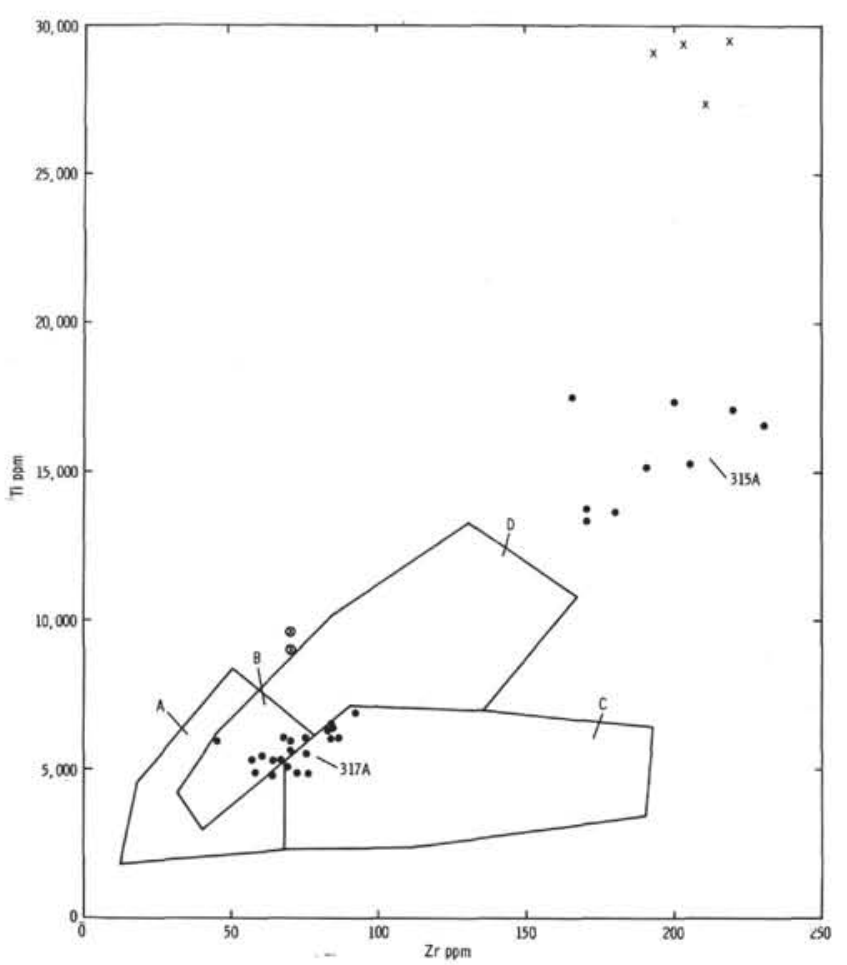

Figure 10. Ti: $\mathrm{Zr}$ diagram comparing Leg 33 basalts with basalts from DSDP Legs 17 (Hole 165A) and 30 (Hole 289). (Crosses from Bass et al., 1973; circled crosses, from Stoeser, in press; fields are from Pearce and Cann, 1973; and dots, Leg 33, Holes $315 \mathrm{~A}$ and $317 \mathrm{~A}$ are from Tables 8 and 9 and calculated from Tables 5 and 7, this report.) According to Pearce and Cann (1973) "ocean floor basalts" plot in fields $D$ and $B$; "low potassium tholeiites" in fields $A$ and $B$, and "calc-alkali basalts" in fields $C$ and $B$.

1971. Vesicularity of mid-oceanic pillow lavas: Canadian J. Earth Sci., v. 8, p. 1314-1319.

Baldwin, B., Coney, P.J., and Dickinson, W.R., 1974. Dilemna of a Cretaceous time scale and rates of sea-floor spreading: Geology, v. 2, p. 267-270.

Bass, M.N., Moberly, R., Rhodes, M.J., and Shih, C., 1973. Volcanic rocks cored in the central Pacific, Leg 17, Deep Sea Drilling Project. In Winterer, E.L., Ewing, J.I., et al., Initial Reports of the Deep Sea Drilling Project, Volume 17: Washington (U.S. Government Printing Office), p. 429-503.

Bastron, H., Barnett, P.R., and Murata, K.J., 1960. Method for the quantitative spectrochemical analysis of rocks, minerals, ores, and other materials by a powder D-C arc technique: U.S. Geol. Surv. Bull. 1084-G, p. 165-182.

Beeson, M.H., 1973. Petrology, mineralogy, and geochemistry of the lavas of east Molokai volcano, Hawaii: Unpublished Ph.D. thesis, University of California at Santa Cruz, p. 151.

Bradley, W.F., 1945. Diagnostic criteria for clay minerals: Am. Mineral., v. 30, p. 704-713.

Dalrymple, G.B., Lanphere, M.A., and Jackson, E.D., 1974. Contributions to the petrography and geochronology of volcanic rocks from the leeward Hawaiian Islands: Geol. Soc. Am. Bull., v. 85 , p. 727-738.

Engel, A.E.J., Engel, C.G., and Havens, R.G., 1967. Chemical characteristics of oceanic basalts and the upper mantle: Geol. Soc. Am. Bull., v. 76, p. 719-734.

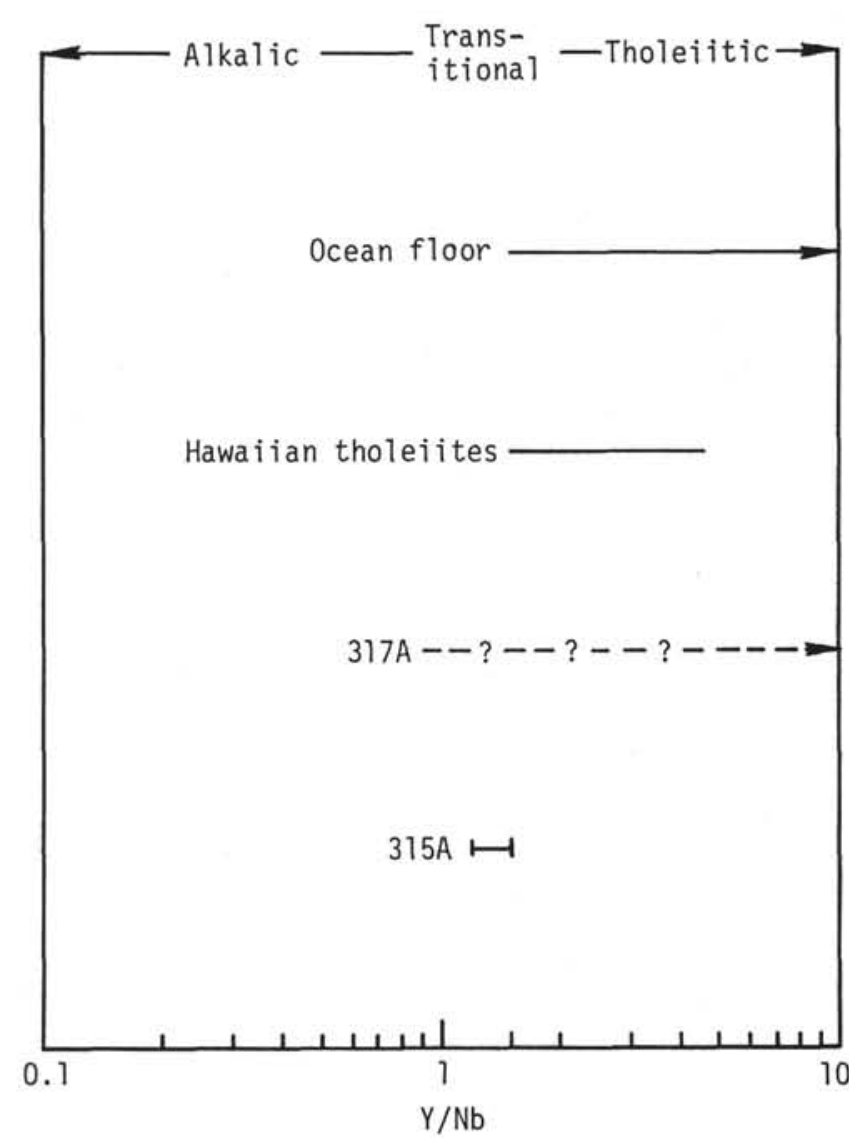

Figure 11. Y/Nb petrographic character diagrams comparing ocean floor basalts, Hawaiian tholeiites and basalts from Leg 33, Holes 315A and 317A. (Ocean floor basalts, Hawaiian tholeiites and fields are from Pearce and Cann, 1973; $315 \mathrm{~A}$ and $317 \mathrm{~A}$ are from Tables 8 and 9, this report.)

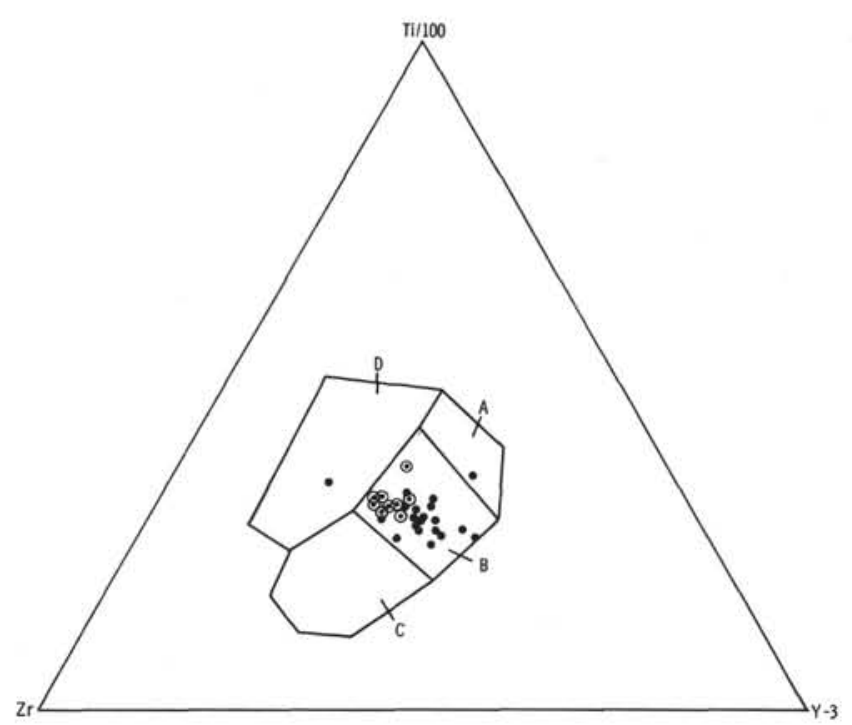

Figure 12. Ti: Zr: $Y$ discrimination diagram of Leg 33 basalts. (After Pearce and Cann, 1973, open circles $315 \mathrm{~A}$ and solid circles $317 A$ data from Tables 5, 6, 8, and 9, this report.) "Within plate basalts" plot in field D "Ocean floor basalts" in field $B$. 


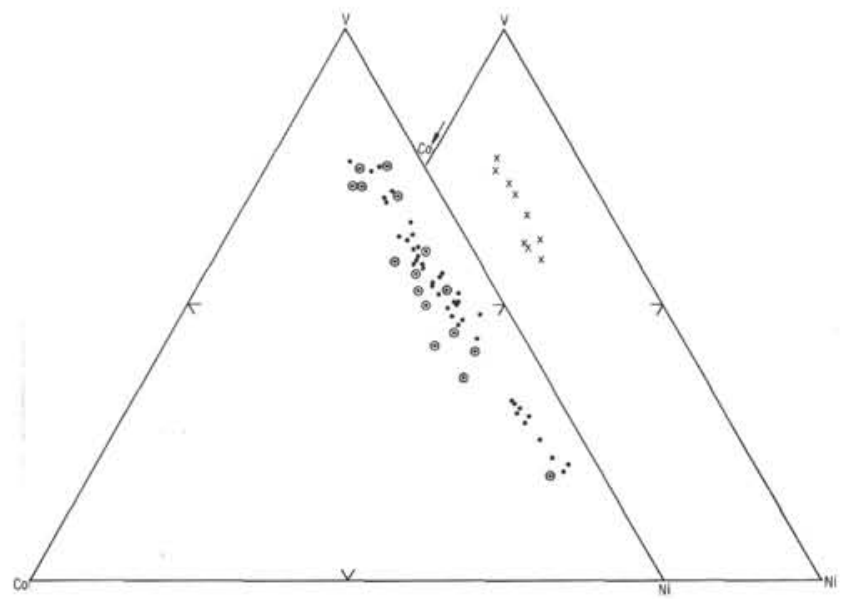

Figure 13a. V-Co-Ni ternary diagram (after Ishikawa, 1968) comparing Hole $315 \mathrm{~A}$ basalts with tholeiitic and alkalic basalts from Hawaii. (Crosses, Hole 315A, this report; dots, Hawaiian tholeiites from Hubbard, 1967; open circles, Hawaiian alkalic basalts from Hubbard, 1967 and unpublished analyses of E. D. Jackson and T. L. Wright.

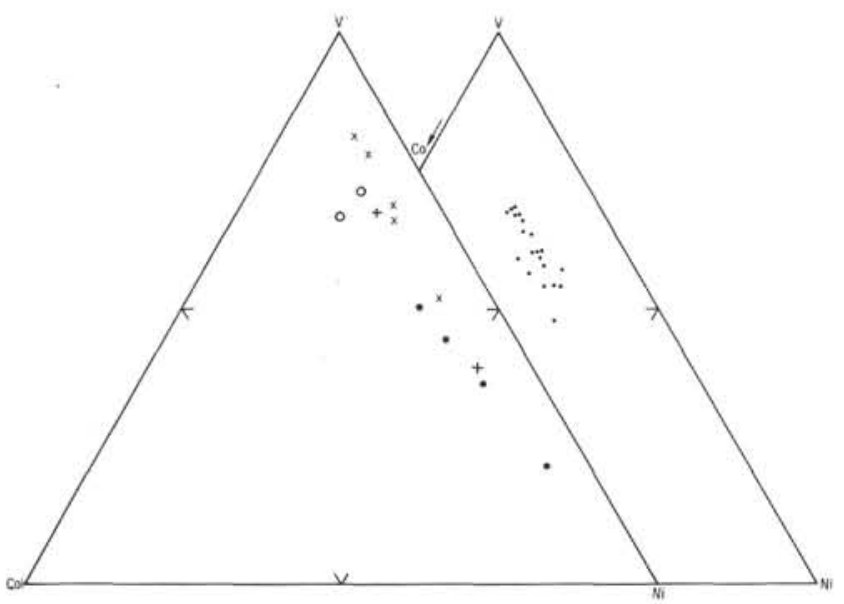

Figure 13b. V-Co-Ni ternary diagram (after Ishikawa, 1968) comparing Hole $317 \mathrm{~A}$ basalts with other oceanic basalts. (Dots 317A, this report; solid circles, Stoeser, in press; open circles, Marshall, in press; crosses, Engel et al., 1965; and pluses, Stewart et al., 1973.

Fabbi, B.P., 1971. X-ray fluorescence determination of barium and strontium in geologic samples: Appl. Spectroscopy, v. 25 , p. $316-318$.

1972. A refined fusion X-ray fluorescence technique, and determination of major and minor elements in silicate standards: Am. Mineral., v. 57, p. 237-245.

1973. X-ray fluorescence determination of sodium in silicate standards using direct dilution and dilution fusion preparation techniques: X-ray Spectrom., v. 2, p. 1517.

Fabbi, B.P. and Espos, L.F., 1972a. X-ray fluorescence determination of $\mathrm{Cl}$ in standard silicate rocks: Appl. Spectroscopy, v. 26, p. 293-295.

1972b. X-ray fluorescence determination of As, Sb, $\mathrm{Ni}, \mathrm{Rb}, \mathrm{Sc}, \mathrm{V}$, and $\mathrm{An}$ in rock standards and other rock samples: in Geological Survey Research 1972: U.S. Geol. Surv. Prof. Paper 800-B, p. B147-B152.
Fabbi, B.P. and Moore, W.J., 1970. Rapid X-ray fluorescence determination of sulfur in mineralized rocks from the Bingham Mining District, Utah: Appl. Spectroscopy, v. 24 , p. $426-428$

Flanagan, F.J., Wright, T.L., Taylor, S.R., Annell, C.S., Christian, R.C., and Dinnin, J.E., in press. Basalt, BHVO1 from Kilauea crater, Hawaii: U.S. Geol. Surv. Prof. Paper 850.

Fodor, R.V., Keil, K., and Bunch, T.E., 1975. Contributions to the mineral chemistry of Hawaiian rocks, V. Pyroxenes in rocks from Haleakala and West Maui volcanoes: Contrib. Mineral. Petrol., v. 50, p. 173-195.

Green-Kelly, R., 1953. The identification of montmorillonoids in clays: J. Soil Sci., v. 4, p. 233-237.

Grim, R.E., 1968. Clay mineralogy: New York (McGraw-Hill Book Co.).

Hart, S.R., 1971. K, Rb, Cs, Sr, and $\mathrm{Ba}$ contents and $\mathrm{Sr}$ isotope ratios of ocean floor basalts: Roy. Soc. London Phil. Trans. Sci. A., v. 268, p. 573-587.

Hart, S.R. and Nalwalk, A.J., 1970. K, Rb, Cs, and $\mathrm{Sr}$ relations in submarine basalts from the Puerto Rico Trench: Geochim. et Cosmochim. Acta, v. 34, p. 145-156.

Haskin, L.A., Haskin, M.A., Frey, F.A., and Wildeman, T.R., 1968. Relative and absolute terrestrial abundances of the rare earths. In Ahrens, L.H., (Ed.), Proc. Symp., IAGC, Paris, 1967: New York (Pergamon Press), p. 889-912.

Hays, J.D. and Pitman, W.C., III, 1973. Lithospheric plate motion, sea level changes and climatic and ecological consequences: Nature, v. 246, p. 18-22.

Heezen, B.E. and Hollister, C.D., 1971. The face of the deep: Oxford, England (Oxford University Press).

Hess, H.H., 1941. Pyroxenes of common mafic magmas: Am. Mineral., v. 26, p. 515-535. 1959. Notes on operation of Frantz Isodynamic Magnetic Separator: Pamphlet published by S.G. Frantz Co., Inc., 6p.

Hubbard, N.J., 1967. Some trace elements in Hawaiian lavas: Unpublished Ph.D Thesis, University of Hawaii. 128 p.

Irvine, T.N. and Baragar, W.R.A., 1971. A guide to the chemical classification of common volcanic rocks: Canadian J. Earth Sci., v. 8, p. 523-548.

Ishikawa, H., 1968. Some aspects of geochemical trends and fields in the ratios of vanadium, nickel, and cobalt: Geochim. Cosmochim. Acta, v. 32, p. 913-917.

Jackson, E.D., 1961. X-ray determination curve for some natural plagioclase of composition An 60-85: U.S. Geol. Surv. Prof. Paper 424C, p. C286-C288.

1974. Linear island chains in the Pacific basin (abstract): Program with Abstracts, International Woollard Symposium, Hawaii Inst. Geophysics, p. 30.

Jackson, E.D. and Wright, T.L., 1970. Xenoliths in the Honolulu Volcanic Series, Hawaii: J. Petrol., v. 11, p. 405430.

Jackson, E.D., Silver, E.A., and Dalrymple, G.B., 1972. Hawaiian-Emperor chain and its relation to Cenozoic circumpacific tectonics: Geol. Soc. Am. Bull., v. 83, p. 601618.

Jackson, E.D., Stevens, T.E., and Bowen, R.W., 1967. A computer-based procedure for deriving mineral formulas from mineral analyses: U.S. Geol. Surv. Prof. Paper, 565C, p. C23-C31.

Kay, R., Hubbard, N.J., and Gast, P.W., 1970. Chemical characteristics and origin of oceanic ridge volcanic rocks: J. Geophys. Res., v. 75, p. 1585-1613.

Keil, K., Fodor, R.V., and Bunch, T.E., 1972. Contributions to the mineral chemistry of Hawaiian rocks, II. Feldspars and interstitial material in rocks from Haleakala and West Maui volcanoes, Maui, Hawaii: Contrib. Mineral. Petrol., v. 37 , p. $253-276$. 


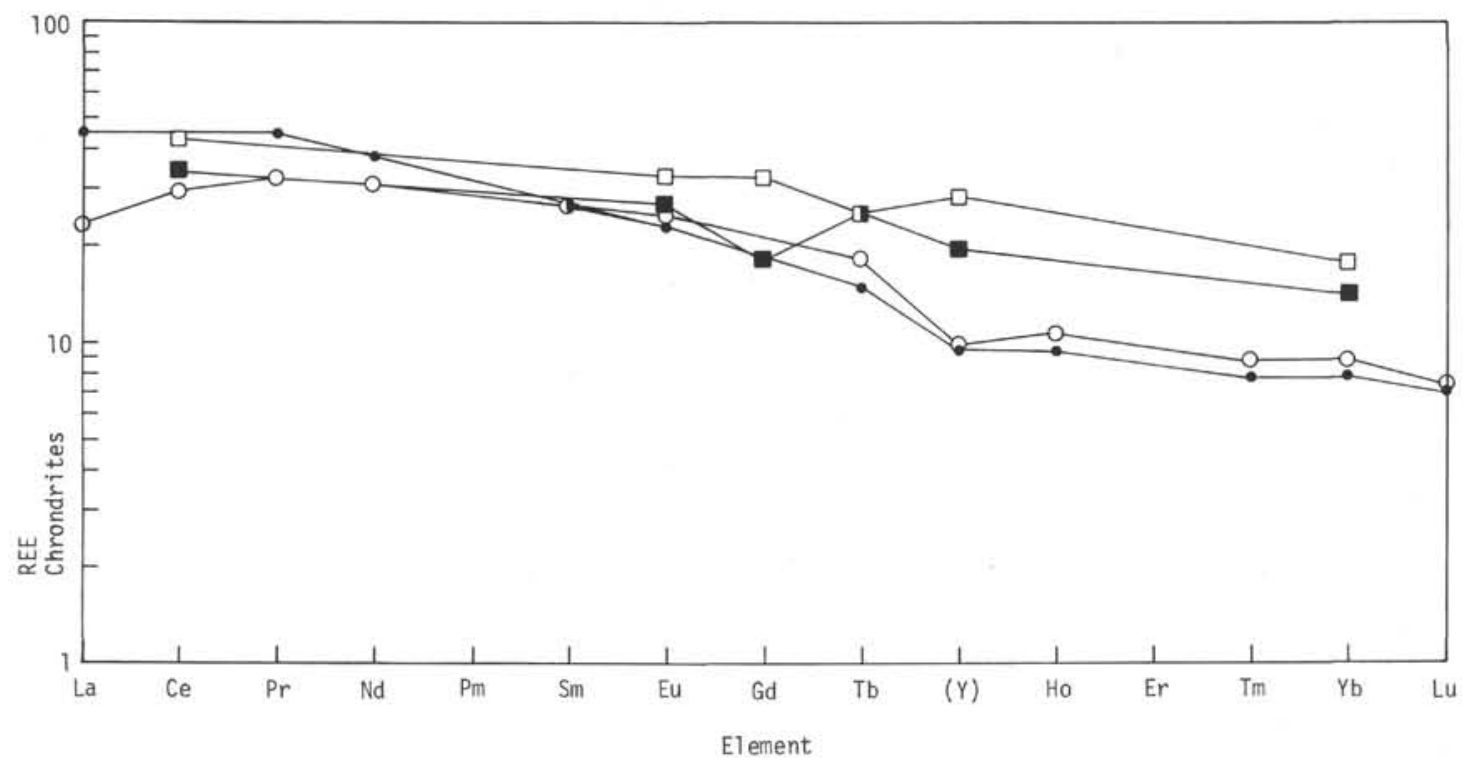

Figure 14a. Chrondrite-normalized trends of rare earth elements for basalts from the Hawaiian Islands compared with those of basalts from Leg 33, Hole 315A. (Solid circles are average Hawaiian alkalic basalts and open circles are average Hawaiian tholeiites from Schilling, 1966; open squares, Sample 315A-34-1, 73.5-75.5 cm, selected for highest Eu value, and solid squares, Sample 315A-32-3, $87.5-89.5 \mathrm{~cm}$, selected for lowest Eu value, from Tables 8 and 10, this report.)(Half solid symbols values coincide.) Our values are chrondrite normalized using data from Haskin et al., 1968.

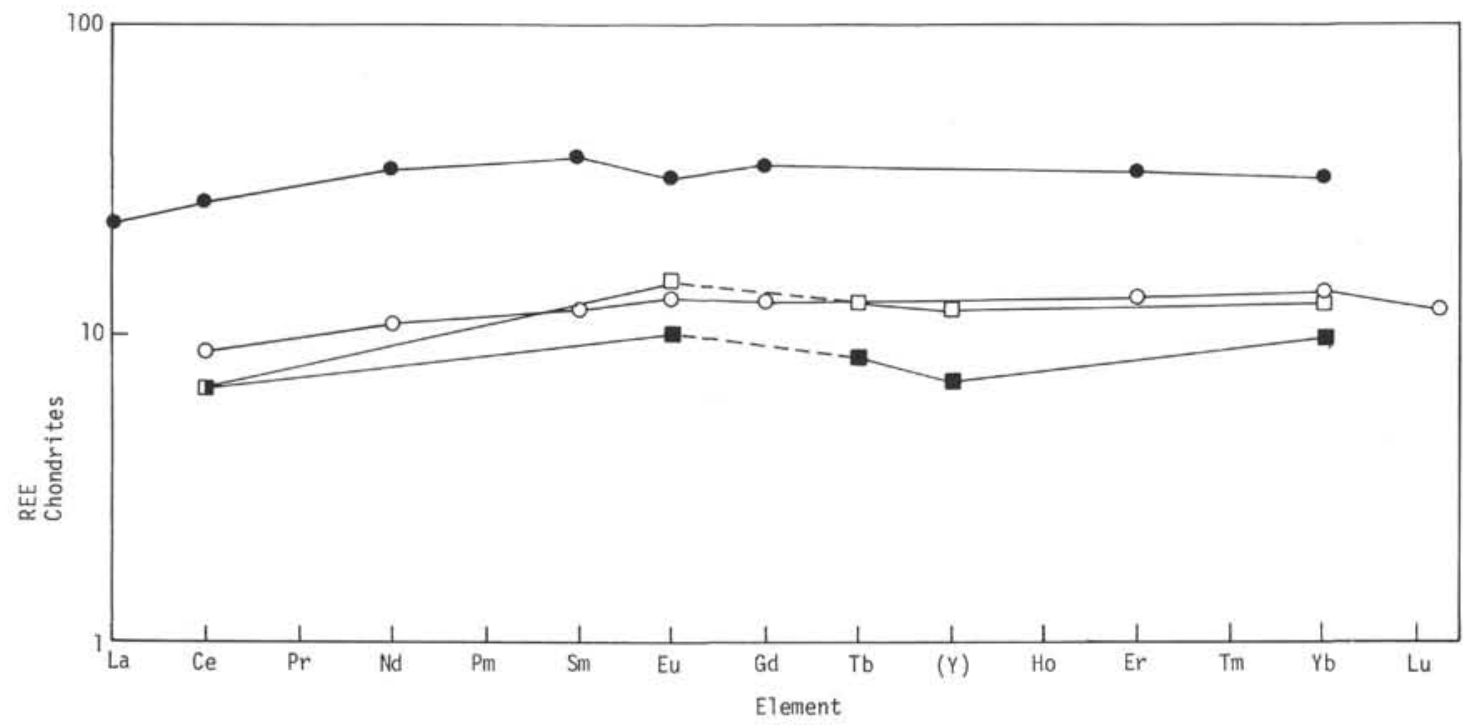

Figure 14b. Chrondrite-normalized trends of rare-earth elements of oceanic ridge basalts compared with those of basalts from Leg 33, Hole 317A. (Solid circles are basalts from the Juan de Fuca ridge from Kay et al., 1970; open circles are basalts from Leg 6, Site 54 from Ridley et al., 1974; open squares, Sample 317A-34-3, 118-120 cm, selected for highest Eu value; closed squares, Sample 317A-32-6, 113-115 cm, from Tables 9 and 11, this report.) (Half solid symbols values coincide.) Our values are chrondrite normalized using data from Haskin et al., 1968. 
TABLE 16a

Range and Average Abundance of Selected Minor Elements in Basalts of Hole 315A Compared With Those of Hawaiian Tholeiites and Alkalic Olivine Basalts

\begin{tabular}{|c|c|c|c|c|c|c|c|}
\hline \multirow[b]{2}{*}{ Element } & \multicolumn{2}{|c|}{ Hole $315 \mathrm{~A}$} & \multicolumn{2}{|c|}{$\begin{array}{l}\text { Hawaiian } \\
\text { Tholeiites }\end{array}$} & \multicolumn{2}{|c|}{$\begin{array}{c}\text { Hawaiian Alkalic } \\
\text { Olivine Basalts }\end{array}$} & \multirow[b]{2}{*}{ Source } \\
\hline & Range & Average & Range & Average & Range & Average & \\
\hline $\mathrm{Ba}$ & $92-144$ & $117^{\mathrm{a}}$ & $50-300$ & 120 & $200-1000$ & 420 & $e, f, g, h, i, j$ \\
\hline $\mathrm{Sr}$ & $237-275$ & $249^{\mathrm{a}}$ & $100-1000$ & 383 & $262-1000$ & 607 & $e, f, g, h, i, j, k$ \\
\hline Co & $43.5-55.9$ & $49.3^{b}$ & $20-71$ & 48 & $30-100$ & 66 & $e, f, g, h, i, j$ \\
\hline $\mathrm{Cr}$ & $\begin{array}{l}75-174 \\
61-145\end{array}$ & $\begin{array}{l}121^{\mathrm{b}} \\
108^{\mathrm{c}}\end{array}$ & $150-1500$ & 567 & $20-1000$ & 433 & $e, f, g, h, i, j$ \\
\hline $\mathrm{Cu}$ & $70-100$ & $87^{\mathrm{d}}$ & $50-200$ & 139 & $30-300$ & 105 & $e, f, g, h, i, j$ \\
\hline $\mathrm{Nb}$ & $32-44$ & $38^{\mathrm{c}}$ & $>10$ & $>10$ & $10-40$ & 20 & $e, f, g, h, i, j$ \\
\hline $\mathrm{Ni}$ & $38-92$ & $66^{\mathrm{c}}$ & $50-1240$ & 235 & $15-972$ & 219 & $e, f, g, h, i, j$ \\
\hline $\mathrm{P}$ & $1091-1397$ & $1314^{\mathrm{a}}$ & $524-2095$ & 1135 & $873-3317$ & 1615 & $1, \mathrm{~m}$ \\
\hline $\mathrm{Sc}$ & $25.9-34.4$ & $29.9^{b}$ & $20-70$ & 32 & $20-50$ & 30 & $e, f, g, h, i, j$ \\
\hline $\mathrm{Ti}$ & $13309-17505$ & $15527^{\mathrm{a}}$ & $10971-22122$ & 14988 & $11091-24100$ & 18045 & $1, \mathrm{~m}$ \\
\hline $\mathrm{V}$ & $170-280$ & 235 & $150-500$ & 289 & $30-500$ & 323 & $e, f, g, h, i, j$ \\
\hline $\mathrm{Y}$ & $39-60$ & $50^{c}$ & $15-50$ & 26 & $19-50$ & 27 & $e, f, g, h, i, j, k$ \\
\hline $\mathrm{Zr}$ & $165-230$ & $192^{\mathrm{c}}$ & $70-247$ & 131 & $70-348$ & 149 & $e, f, g, h, i, j$ \\
\hline
\end{tabular}

${ }^{a} \mathrm{X}$-ray fluorescence analyses.

$\mathrm{b}_{\text {Radioactivation and radiochemistry analyses. }}$

${ }^{c}$ Quantitative spectrographic analyses.

$\mathrm{d}_{\text {Semiquantitative spectrographic analyses. }}$

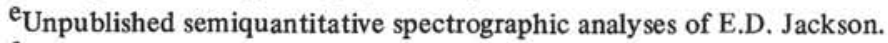

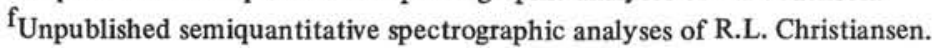

g Unpublished semiquantitative spectrographic analyses of D.A. Swanson.

${ }^{h}$ Unpublished semiquantitative spectrographic analyses of R.I. Tilling.

${ }^{i}$ Unpublished semiquantitative spectrographic analyses of T.L. Wright.

TABLE 16b

Range and Average Abundance of Selected Minor Elements in Basalts of Hole 317A Compared With Those of Other Oceanic Ridge Basalts

\begin{tabular}{|c|c|c|c|c|c|}
\hline \multirow[b]{2}{*}{ Element } & \multicolumn{2}{|c|}{ Hole 317A } & \multicolumn{2}{|c|}{$\begin{array}{l}\text { Oceanic Ridge } \\
\text { Basalts }\end{array}$} & \multirow[b]{2}{*}{ Source } \\
\hline & Range & Average & Range & Average & \\
\hline $\mathrm{Ba}$ & $<22$ & $<22^{\mathrm{a}}$ & $2-180$ & 25 & $e, f, g, h$ \\
\hline $\mathrm{Sr}$ & $81-118$ & $100^{\mathrm{a}}$ & $70-440$ & 199 & $e, f, g, h, i, j$ \\
\hline Co & $41.1-51.3$ & $47.4^{b}$ & $6-75$ & 42 & $e, f, g, h, j$ \\
\hline $\mathrm{Cr}$ & $\begin{array}{l}130-920 \\
125-683\end{array}$ & $\begin{array}{l}360^{c} \\
373^{b}\end{array}$ & $70-700$ & 320 & $\mathrm{e}, \mathrm{f}, \mathrm{g}, \mathrm{h}$ \\
\hline $\mathrm{Cu}$ & $50-200$ & $112^{d}$ & $10-700$ & 148 & $e, f, g, h, j$ \\
\hline $\mathrm{Nb}$ & $<15$ & $<15^{\mathrm{c}}$ & $1.9-88$ & 14 & $\mathrm{i}, \mathrm{j}$ \\
\hline $\mathrm{Ni}$ & $60-120$ & $82^{c}$ & $15-500$ & 149 & $e, f, g, h, i$ \\
\hline $\mathbf{P}$ & $436-742$ & $563^{\mathrm{a}}$ & $131-2226$ & 865 & $e, f, g, h, i, j$ \\
\hline $\mathrm{Sc}$ & $40.4-48.4$ & $44.1^{\mathrm{b}}$ & $30-70$ & 51 & $e, f, g, h, j$ \\
\hline $\mathrm{Ti}$ & $4796-6894$ & $5681^{\mathrm{a}}$ & $3537-17086$ & 9452 & $e, f, g, h, i, j$ \\
\hline V & $125-240$ & $201^{\mathrm{c}}$ & $150-440$ & 246 & $e, f, g, h$ \\
\hline$Y$ & $14-34$ & $24^{c}$ & $15-100$ & 37 & $e, f, g, h, i, j$ \\
\hline $\mathrm{Zr}_{\mathrm{r}}$ & $45-92$ & $72^{c}$ & $15-950$ & 137 & $e, f, g, h, i, j$ \\
\hline $\begin{array}{l}{ }^{\mathrm{a}} \text { X-ray flu } \\
\mathrm{b}_{\text {Radioac }} \\
{ }^{\mathrm{c}} \text { Quantita } \\
{ }^{\mathrm{d}} \text { Semiqua } \\
{ }^{\mathrm{e}} \text { Stoeser }\end{array}$ & $\begin{array}{l}\text { rescence ans } \\
\text { vation and } \mathrm{r} \\
\text { ive spectrogr } \\
\text { titative spec } \\
\text { n press). }\end{array}$ & $\begin{array}{l}\text { yses. } \\
\text { liochemis } \\
\text { phic analy }\end{array}$ & nalyses. & $\begin{array}{l}\text { gel et al } \\
\text { ewart et } \\
\text { ss et al. } \\
\text { cLeod a }\end{array}$ & $\begin{array}{l}1965) . \\
(1973) . \\
73) . \\
\text { Pratt (1973). }\end{array}$ \\
\hline
\end{tabular}


Laniz, R.V., Stevens, R.E., and Norman, M.B., 1964. Staining of plagioclase feldspar and other minerals with F.D. and C red no. 2: U.S. Geol. Surv. Prof. Paper 501B, p. B152B153.

Larson, R.L. and Chase, C.G., 1972. Late Mesozoic evolution of the western Pacific ocean: Geol. Soc. Am. Bull., v. 83, p. 3627-3644.

Macdonald, G.A., 1968. Composition and origin of Hawaiian lavas. In Coats, R.R., Hay, R.L., and Anderson, C.A. (Eds.), Studies in volcanology: Geol. Soc. Am. Mem. 116, p. 477-522.

Macdonald, G.A. and Katsura, T., 1964. Chemical composition of Hawaiian lavas: J. Petrol., v. 5, p. 82-133.

Macleod, N.S. and Pratt, R.M., 1973. Petrology of volcanic rocks recovered on Leg 18, Deep Sea Drilling Project. In Kulm, L.D., von Huene, R., et al., Initial Reports of the Deep Sea Drilling Project, Volume 18: Washington (U.S. Government Printing Office), p. 935-945.

Marshall, M., 1975. Petrology and chemical composition of basaltic rocks recovered on Leg 32, Deep Sea Drilling Project. In Larson, R.L., Moberly, R., Jr., et al., Initial Reports of the Deep Sea Drilling Project, Volume 32: Washington (U.S. Government Printing Office). p. 563-570.

Matthews, D.H., 1971. Altered basalts from Swallow Bank, an abyssal hill in the NE Atlantic, and from a nearby seamount: Roy. Soc. London Phil. Trans. Sci. A, v. 268, p. 551-571.

Moberly, R., Jr., and Heath, G.R., 1971. Volcanic rocks from the western and central Pacific: Leg 7, Deep Sea Drilling Project. In Winterer, E. L., Riedel, W.R., et al., 1971, Initial Reports of the Deep Sea Drilling Project, Volume 7: Washington (U.S. Government Printing Office), p. 1011-1026.

Moore, J.G., 1965. Petrology of deep-sea basalt near Hawaii: Am. J. Sci., v. 263, p. 40-52.

Moore, J.G. and Schilling, J.G., 1973. Vesicles, water, and sulfur in Reykjanes ridge basalts: Contrib. Mineral. Petrol., v. 41 , p. 105-118.

Mumpton, F.A., 1960. Clinoptilolite redefined: Am. Mineral., v. 45 , p. $351-369$.

Murata, K.J. and Whitely, K.R., 1973. Zeolites in the Miocene Briones sandstone and related formations of the central Coast Ranges, California: U.S. Geol. Surv. J. Res., v. 1 , p. $255-265$.

Myers, A.T., Havens, R.G., and Dunton, P.J., 1960. A spectrochemical method for the semiquantitative analysis of rocks, minerals, and ores: U.S. Geol. Surv. Bull. 1084-I, p. 207-229.

Pearce, J.A. and Cann, J.R., 1973. Tectonic setting of basic volcanic rocks determined using trace element analyses: Earth and Planet. Sci. Lett., v. 19, p. 290-300.
Peck, L.C., 1964. Systematic analysis of silicates: U.S. Geol. Surv. Bull. 1170.

Pitman, W.C., III, Larson, R.L., and Herron, E.M., 1974. Ages of the ocean basins determined from magnetic anomaly lineations: Magnetic lineations of the oceans, Geol. Soc. Am. Special Map.

Ridley, I., Rhodes, J.M., Reid, A.M., Jakes, P., Shih, C., and Bass, M.N., 1974. Basalts from Leg 6 of the Deep Sea Drilling Project: J. Petrol., v. 15, p. 140-159.

Schilling, J.G., 1966. Rare earth fractionation in Hawaiian volcanic rocks: Unpublished Ph.D Thesis, Massachusetts Institute Technology, $390 \mathrm{p}$.

1971. Sea-floor evolution: rare earth evidence: Roy, Soc. London Phil. Trans. Ser. A., v. 268, p. 663-706. 1973. Iceland mantle plume: Geochemical study of Reykjanes ridge: Nature, v. 242, p. 565-571.

Schoen, R. and Lee, D.E., 1964. Successful separation of siltsize minerals in heavy liquids: U.S. Geol. Surv. Prof. Paper 501-B, p. B154-157.

Shand, S.J., 1939. On the staining of feldspathoids, and on zonal structure in nepheline: Am. Mineral., v. 24, p. 508513.

Shih, C., 1974. Rare earth goechemistry of basaltic rocks from Leg 17 of the Deep Sea Drilling Project (abstract): Abstracts with Programs, v. 6, (Boulder, Colo.), p. 952-953.

Stewart, R.J., Natland, J.H., and Glassby, W.R., 1973. Petrology of volcanic rocks from the North Pacific Ocean and the Bering Sea. In Creager, J.S., Scholl, D.W., et al., Initial Reports of the Deep Sea Drilling Project, Volume 19: Washington (U.S. Government Printing Office), p. 615-628.

Stoeser, D. B., in press. Igneous rocks from Leg 30 of the Deep Sea Drilling Project. In Andrews, J.E., Packham, G., et al. Initial Reports of the Deep Sea Drilling Project, Volume 30: Washington (U.S. Government Printing Office).

Sutton, G.H., Meynard, G.L., and Hussong, D.M., 1970. Widespread occurrences of a high velocity layer in the capitol Pacific crust, found with repetitive sources and sonabuoys. In Heacock, J.G. (Ed.), Structural and physical properties of the earth's crust: Geophys. Mono., v. 14, p. 193-209.

Winterer, E.L., Lonsdale, P.F., Matthews, J.L., and Rosendahl, B.R., 1974. Structure and acoustic stratigraphy of the Manihiki Plateau: Deep-Sea Res., v. 21, p. 793-814.

Wright, T.L., 1970 Mineral norms-Mod I: U.S. Geol. Surv. Computer Contrib. C-463.

1971. Chemistry of Kilauea and Mauna Loa Lava in space and time: U.S. Geol. Surv. Prof Paper 735, 40 p. 
TABLE 17

Dry Reduced Chemical Analyses and Norms of Basalts From Hualalai Volcano, Hawaii, DSDP Leg 17 (Hole 165A) and DSDP Leg 30 (Hole 289)

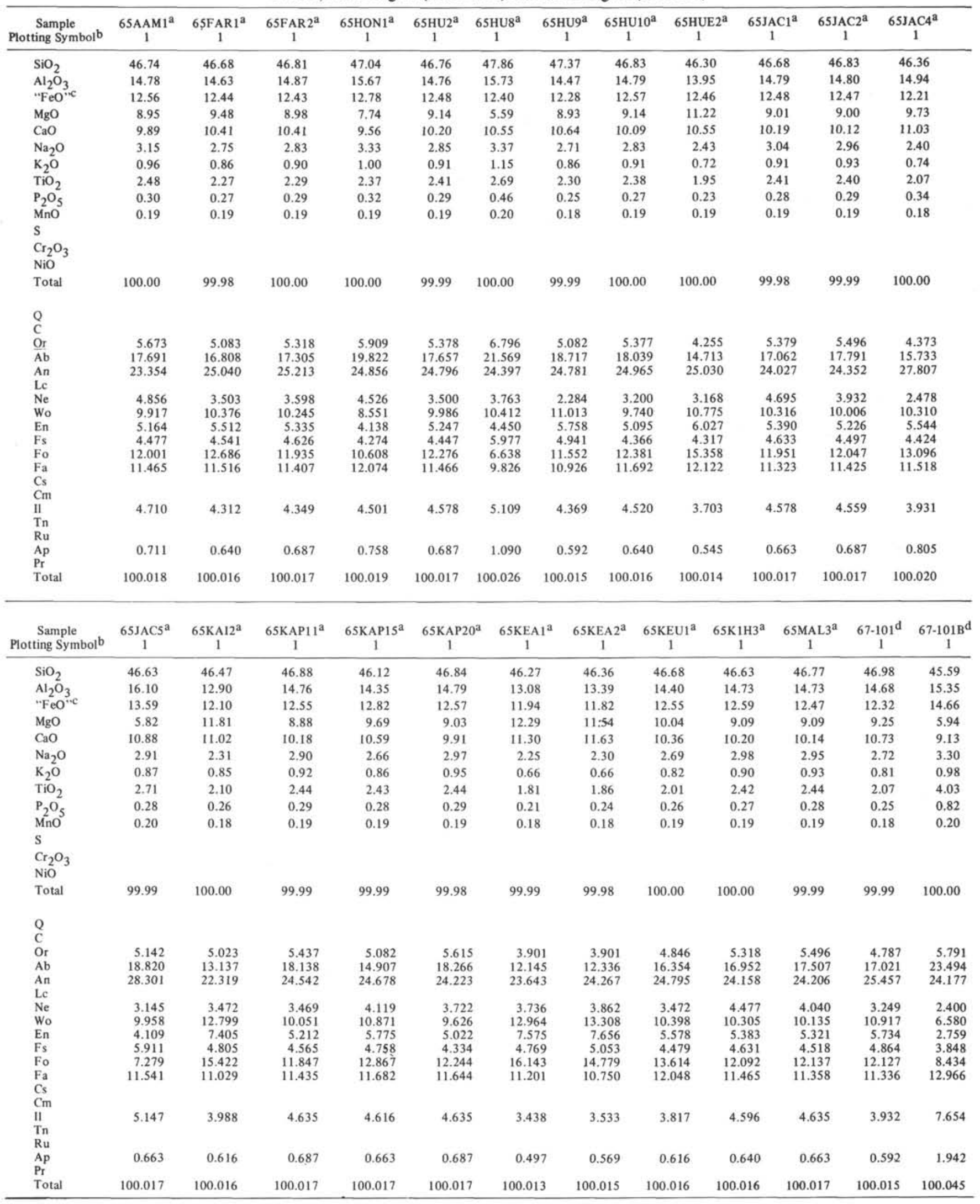

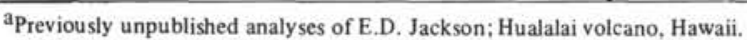

${ }^{b}$ For 1. W, X, Y, and Z, see Figures 15-17; for 3 and 4, see Figures 18-20.

c. $\mathrm{FeO}$ " is $\mathrm{FeO}$ plus $0.9 \mathrm{Fe}_{2} \mathrm{O}_{3}$ after summing to $100 \%$ dry weight.

dPreviously unpublished analyses of T.L. Wright; Hualalai volcano, Hawaii. 
TABLE 17 - Continued

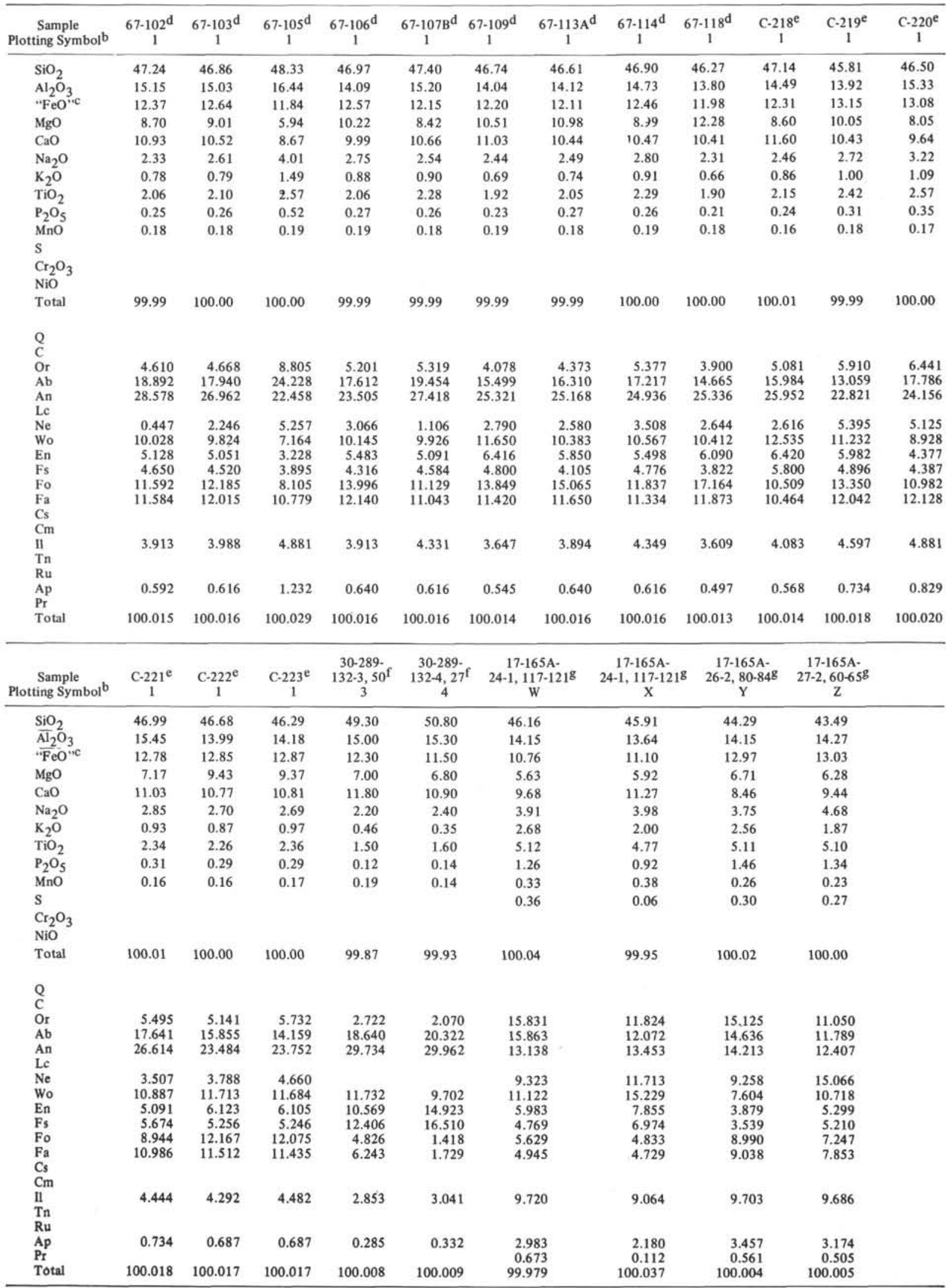

Analyses from Macdonald (1968); Hualalai volcano, Hawaii.

$f_{\text {Analyses from Stoeser (in press). }}$

BAnalyses from Bass et al. (1973). 

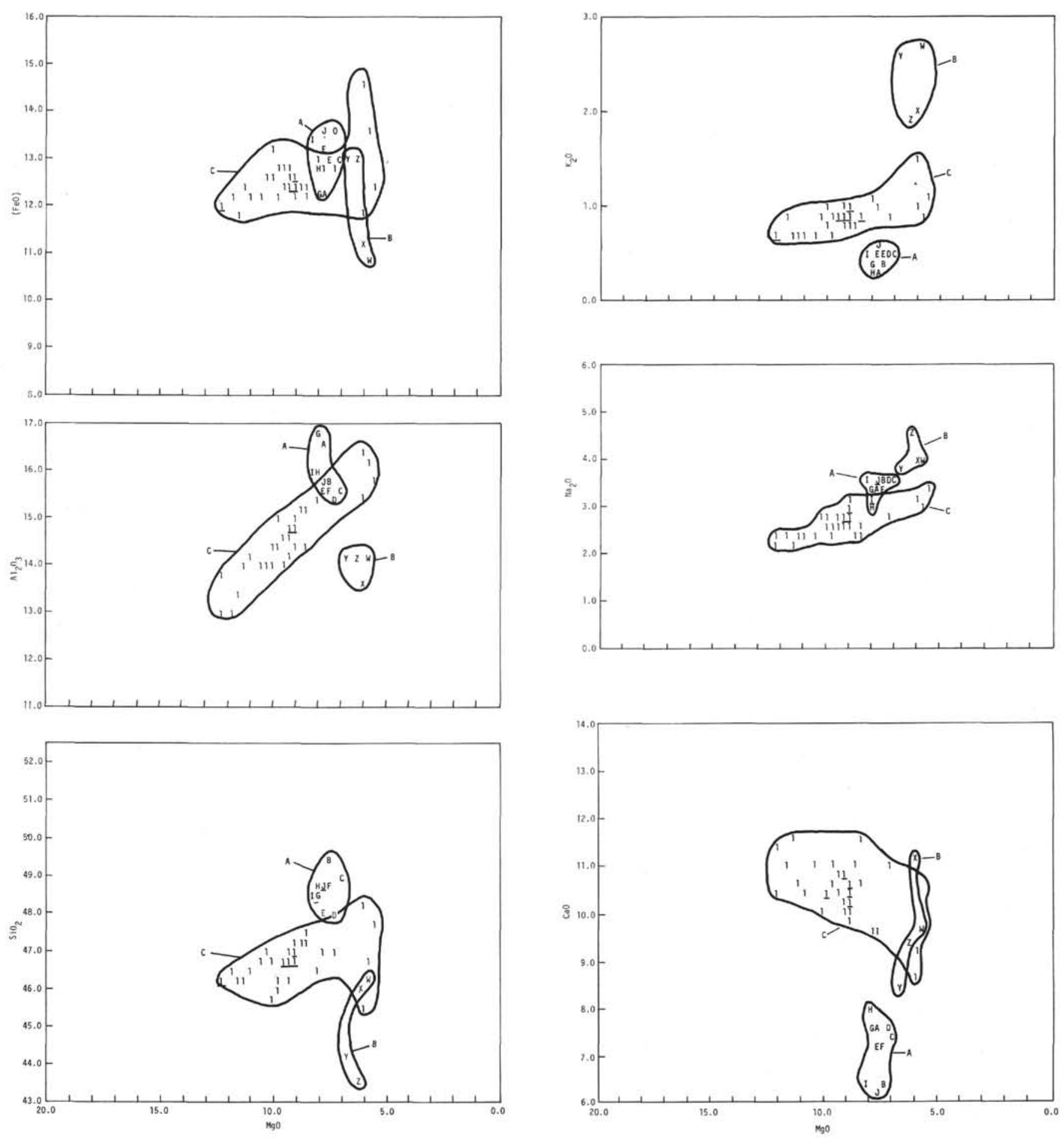

Figure 15. MgO variation diagrams for dry, reduced oxides of basalts from Leg 33 (Hole 315A) compared with basalts from Leg 17 (Hole 165A) and the Hualalai volcanic series from Hawaii. (A 315A from Table 13, this report; B (Hole 165A) calculated from Bass et al., 1973 Table 17, this report; and C (Hualalai basalts) calculated from Macdonald, 1968 (GAM), and unpublished analyses of E. D. Jackson (EDJ) and T. L. Wright (TLW) from Table 17, this report.) Underlined symbols indicate more than one sample plotted at that point. 
PETROLOGY OF THE BASALTIC ROCKS
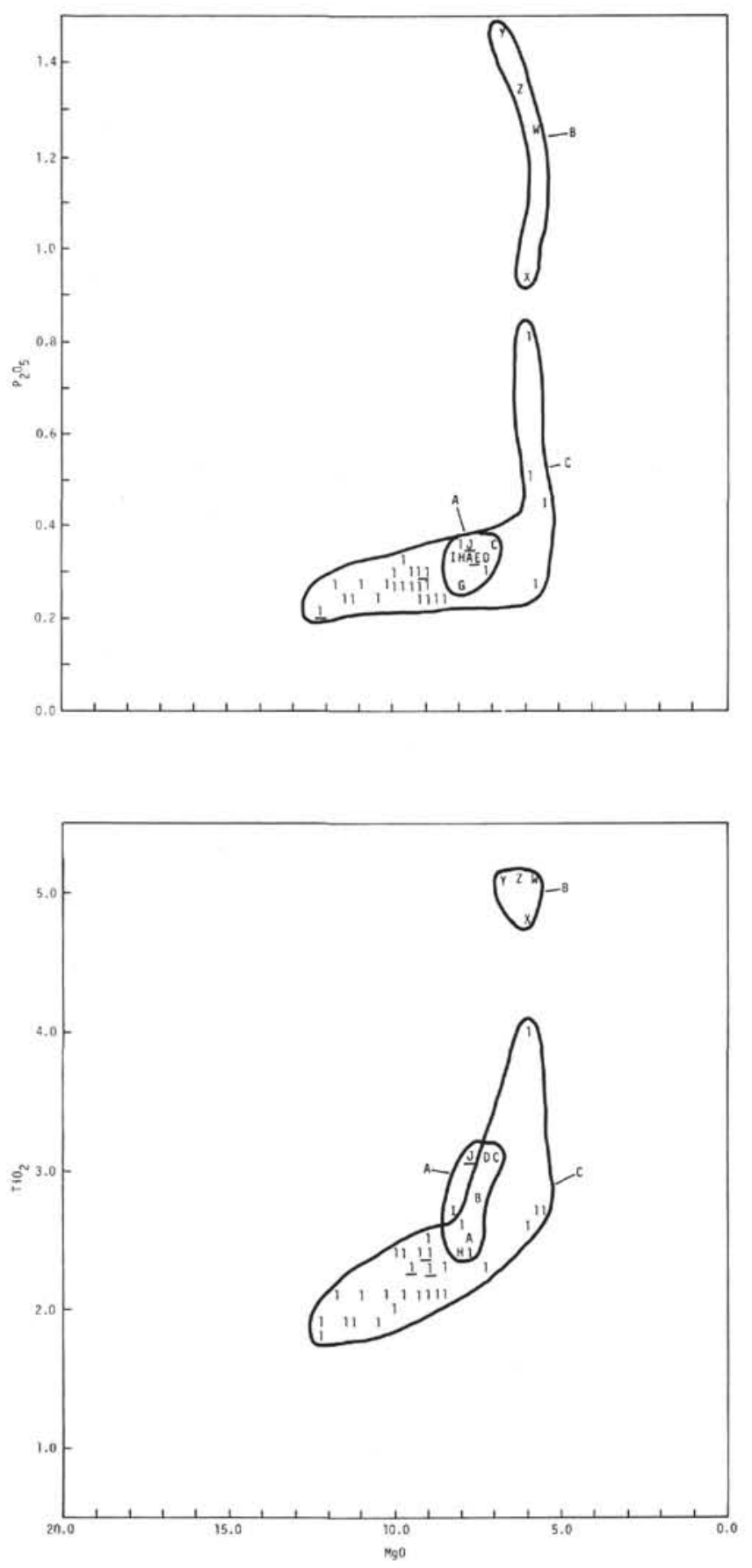

Figure 15. (Continued)

609 


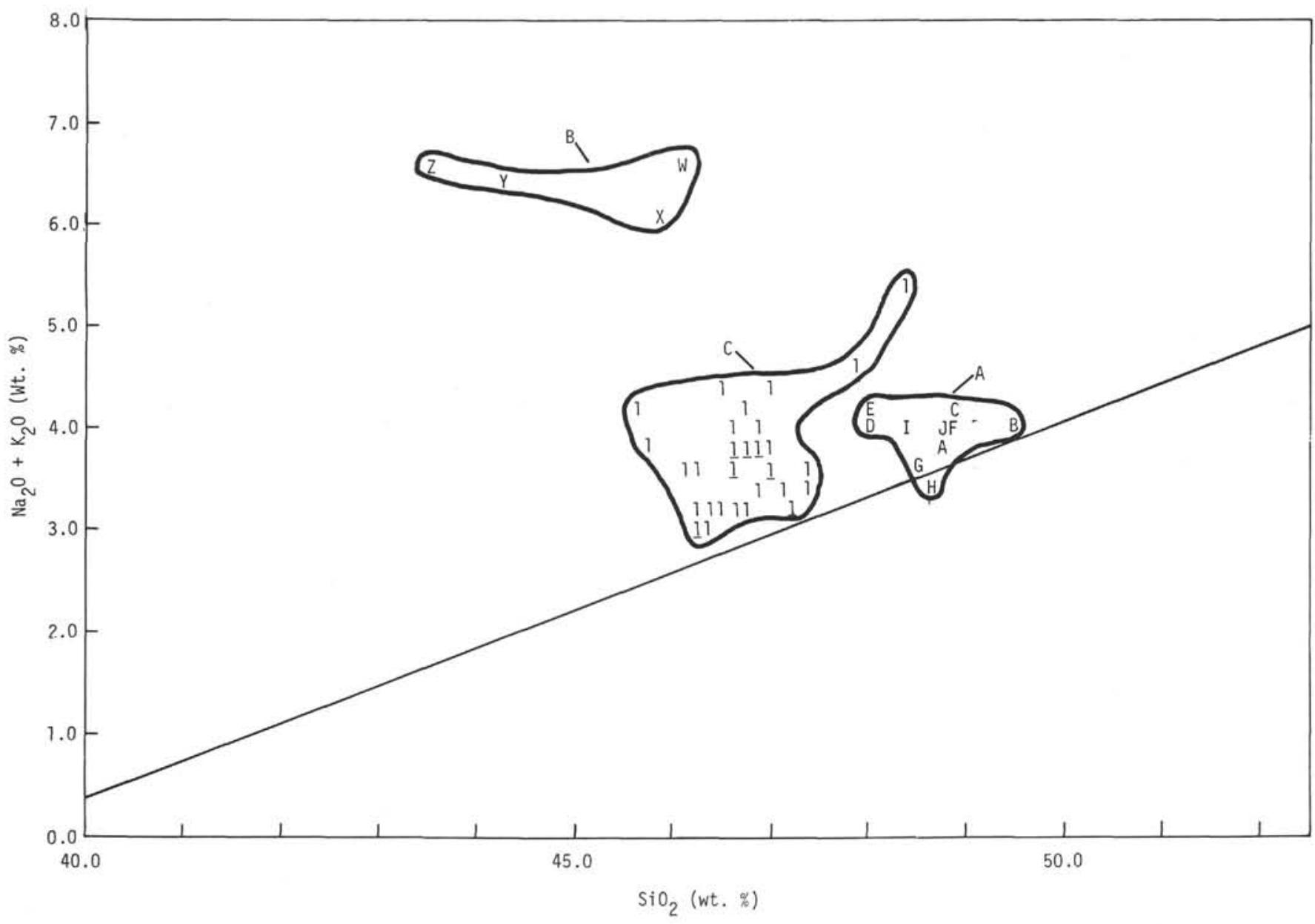

Figure 16. Alkali:silica diagram (after Macdonald and Katsura, 1964) comparing Leg 33 (Hole 315A) basalts with basalts from Leg 17 (Hole 165A) and Hualalai volcano, Hawaii. (Underlined symbols and references same as in Figure 15.)

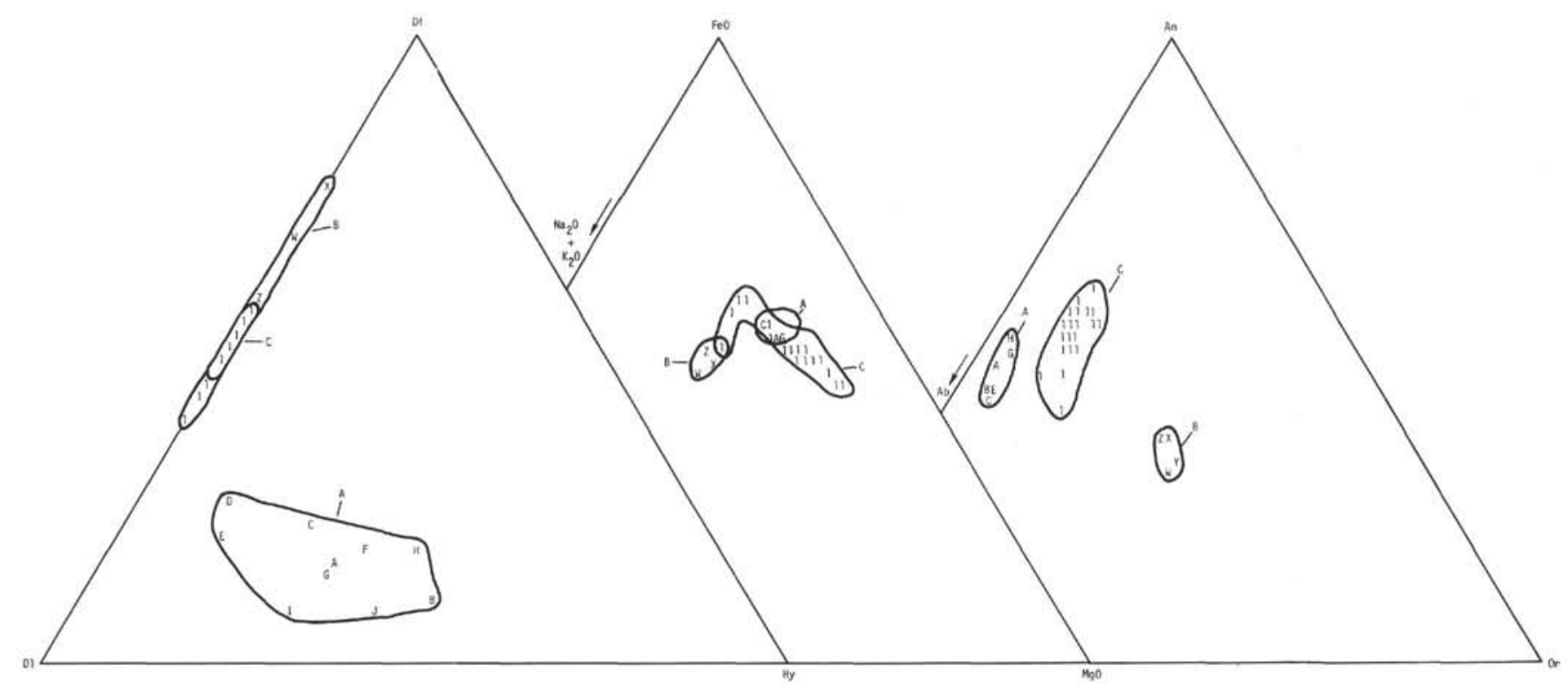

Figure 17. A-F-M, DI-OL-HY, and An-Ab-Or ternary diagrams (after Irvine and Baragar, 1971) comparing Leg 33 (Hole 315A) basalts from Leg 17 (Hole 165A) and the Hualalai volcanic series. (Underlined symbols and references same as in Figure 15.) 

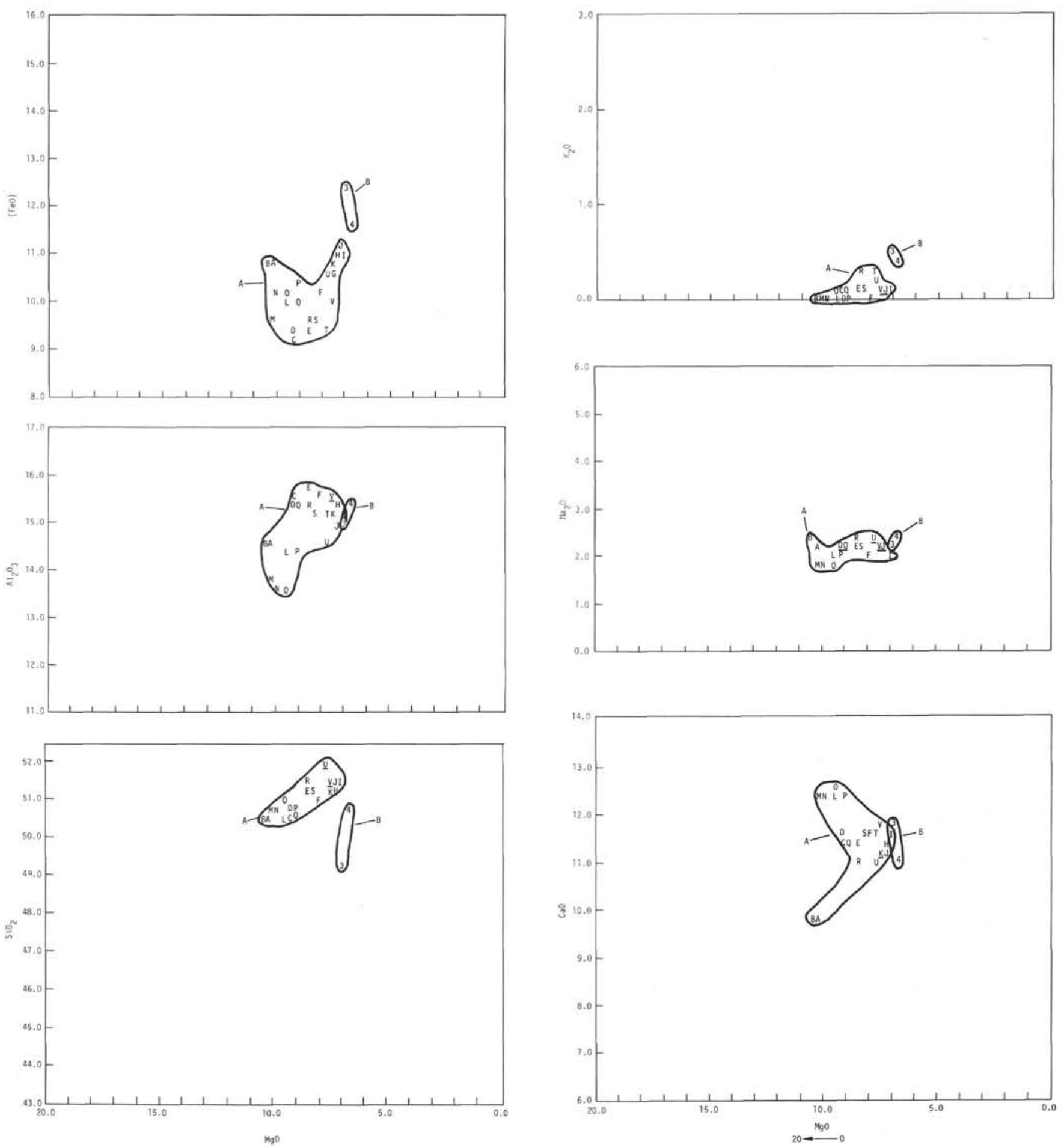

Figure 18. $\mathrm{MgO}$ variation diagrams for dry, reduced oxides of basalts from Leg 33 (Hole 317A) compared with Leg 30 (Hole 289) basalts. (A 317A from Table 14, this report; B calculated from Stoeser (in press) for Table 17, this report.) Note that point $E$ which represents Flow Unit $5 A$ is nearly identical in all elements with analyses $F-K$ of Flow Unit $5 B$. Similarly points $L-N$ which represent Flow Unit $6 A$ group with points $O-Q$ of Flow Unit $6 B$. Again points $R$ of Flow Unit $7 A$ and $S$ of Flow Unit $7 B$ fall together. This suggests the petrographic grouping of these flow units is supported by bulk chemical data. Underlined symbols indicate that more than one sample plotted at that point. 
E. D. JACKSON, K. E. BARGAR, B. P. FABBI, C. HEROPOULOS
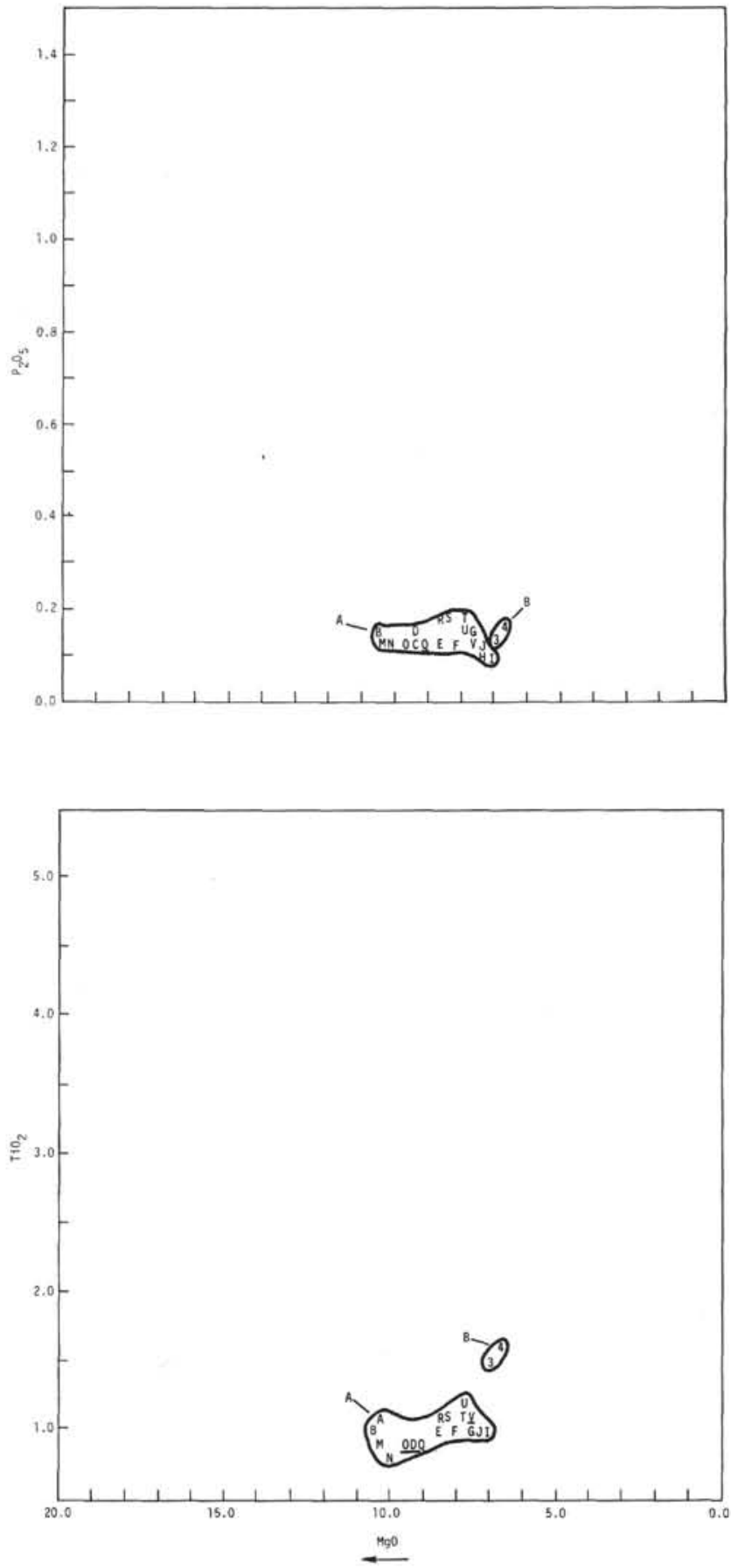

Figure 18. (Continued) 


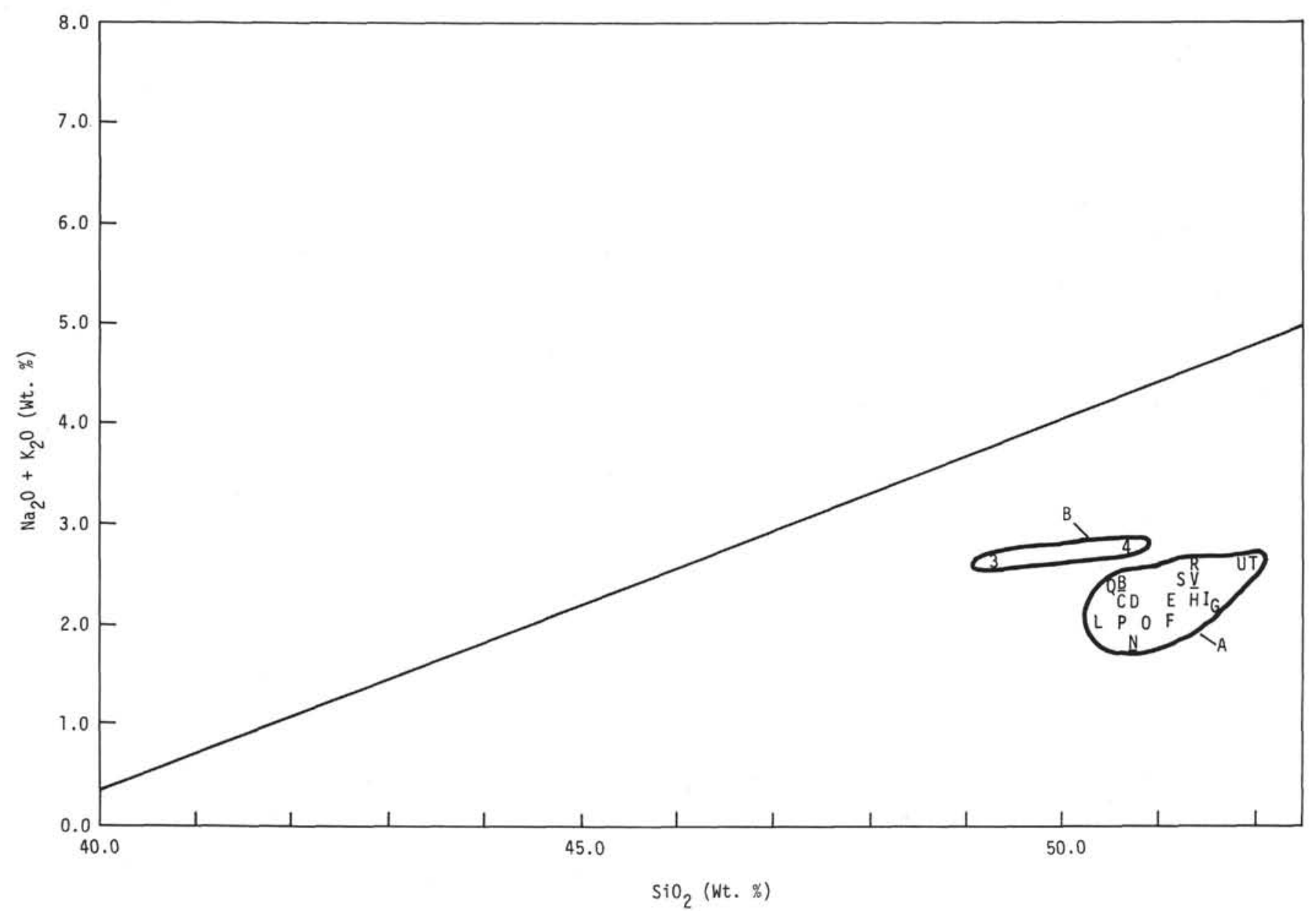

Figure 19. Alkali:silica diagram (after Macdonald and Katsura, 1964) comparing Leg 33 (Hole 317A) basalts with basalts from Leg 30 (Hole 389). (Underlined symbols and references same as in Figure 18.)

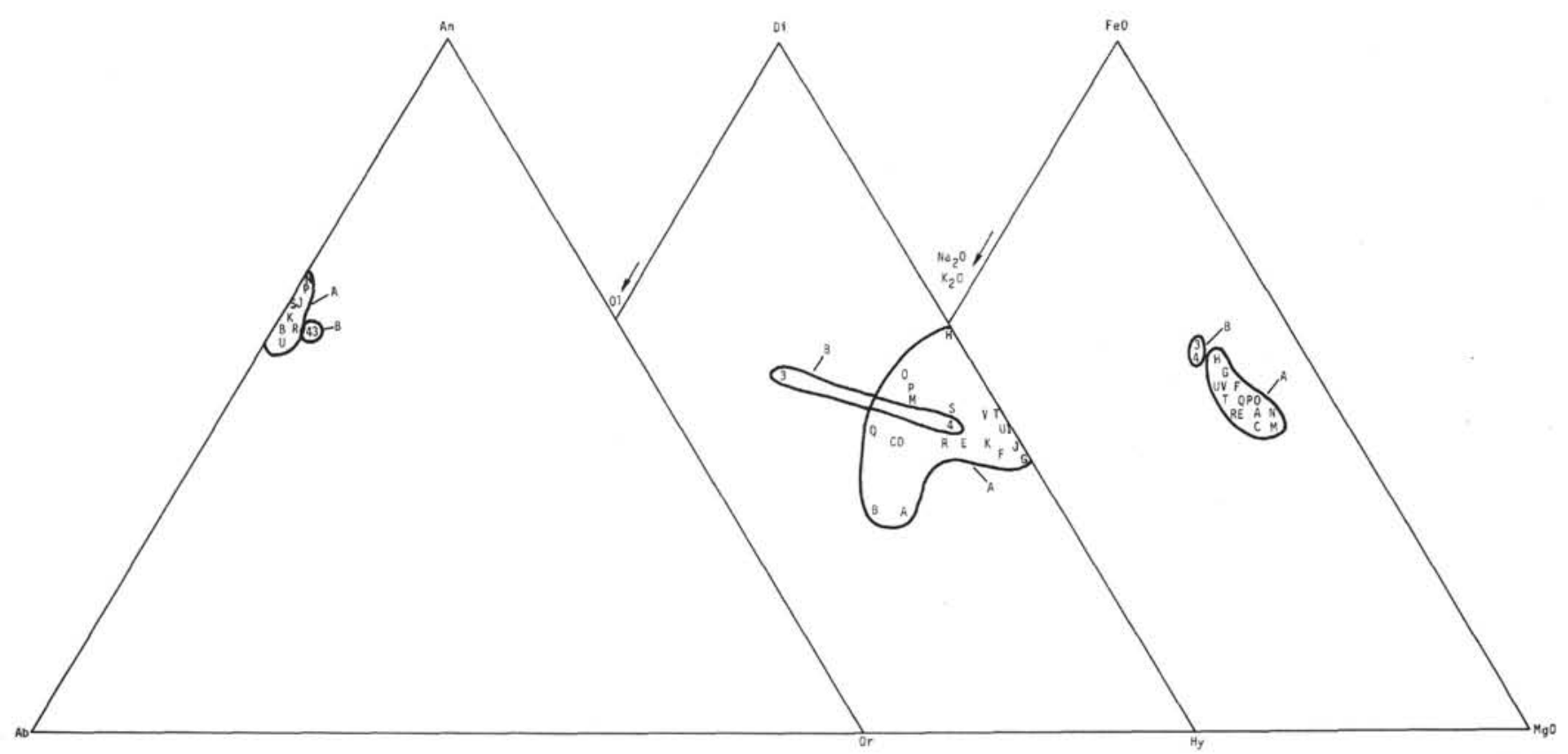

Figure 20. A-F-M, DI-OL-HY, and An-Ab-Or ternary diagrams (after Irvine and Baragar, 1971) comparing Leg 33 (Hole 317 A) basalts with basalts from Leg 30 (Hole 389). (Underlined symbols and references same as in Figure 18.) 
PLATE 1

Photomicrographs of Sample 315A-32-2, 105-106 cm, a finer grained variant of Flow Unit 2.

Figure 1 Notch in section is up core, and section is cut in the vertical plane of the core. Crossed nicols. Vertical dimension is $11 \mathrm{~mm}$. White laths are plagioclase, rounded, darker gray areas are vesicles filled with green montmorillonite. Lighter gray areas between plagioclase are augite. Slight alinement of plagioclases perpendicular to core axis is evident, but must less well developed than in other samples. Texture diabasic.

Figure 2 Section cut in horizontal plane of core. Vertical dimension is $8.3 \mathrm{~mm}$, plane light. Darkest areas are filled vesicles. Centers of plagioclase grains are altered to brown montmorillonite.

Figure 3 Same as 2; crossed nicols. 


\section{PLATE 1}
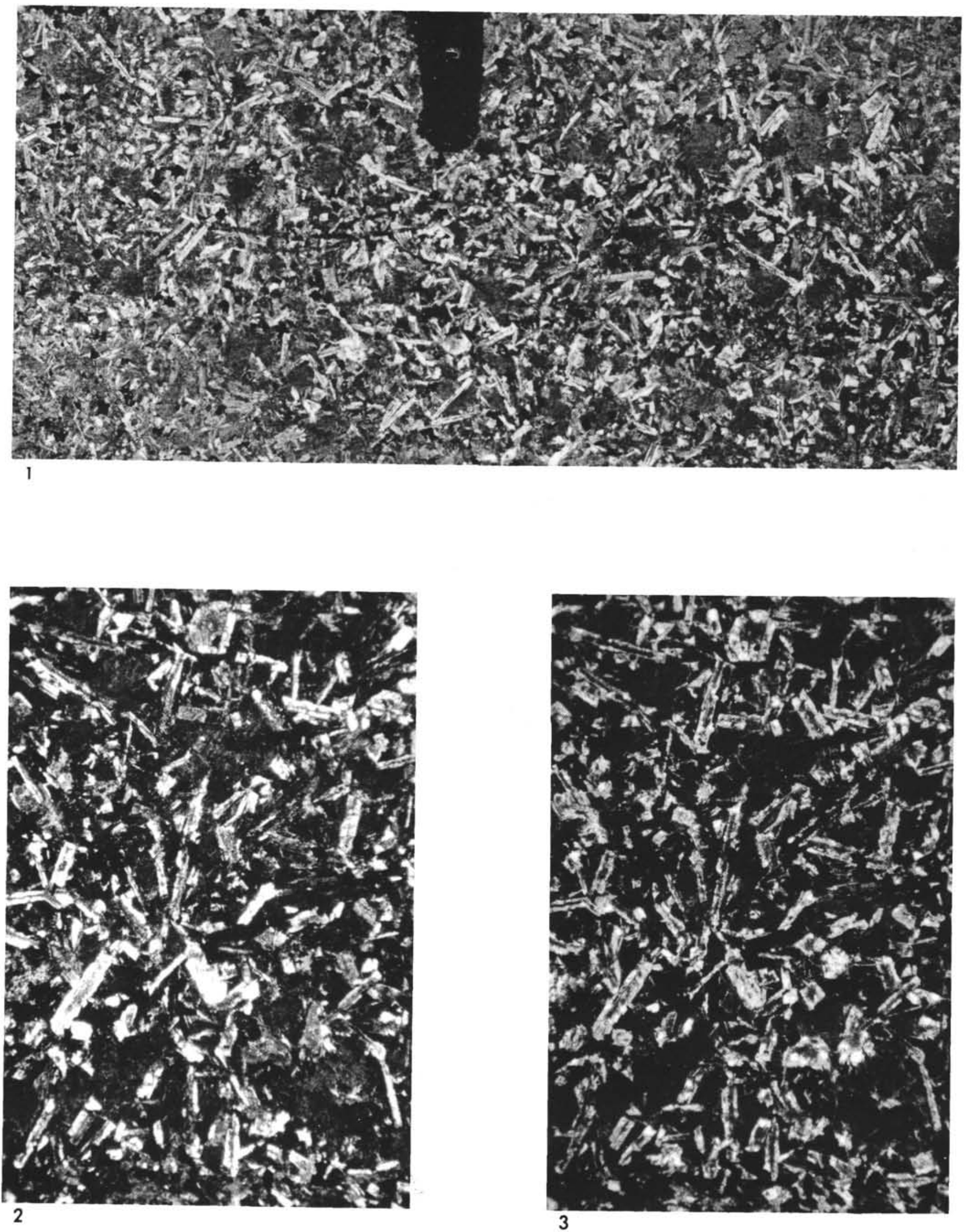


\section{PLATE 2}

Photomicrographs of samples from Hole 317A

Figure 1 Sample 317A-32-3, 96-97.8 cm. Area of slide $15 \times$ $15 \mathrm{~mm}$. Plane light. Section cut in the vertical plane of the core. Three vesicles are present, one at lower-right edge, filled with green montmorillonite. One in center and one in upper-right rimmed by brown montmorillonite. Intermediate gray areas are microphenocrysts of augite and pigeonite. Texture is diabasic to intersertal. Flow Unit $5 \mathrm{~B}$.

Figure 2 Same as 1, crossed nicols.

Figure 3 Same sample as 1 and 2. Area of slide is $2.3 \times 2.3$ $\mathrm{mm}$. Plane light. Former groundmass glass in wedge-shaped interstices is altered to brown montmorillonite.

Figure $4 \quad$ Same as 3, crossed nicols.

Figure 5 Sample 317A-34-4, 62-64 cm. Area of slide is $5.6 \times$ $5.6 \mathrm{~mm}$. Plane light. Glomeroporphyritic clots of pyroxene and plagioclase in a vitrophyric groundmass. Flow Unit 10.

Figure $6 \quad$ Same as 5, crossed nicols. 
PLATE 2

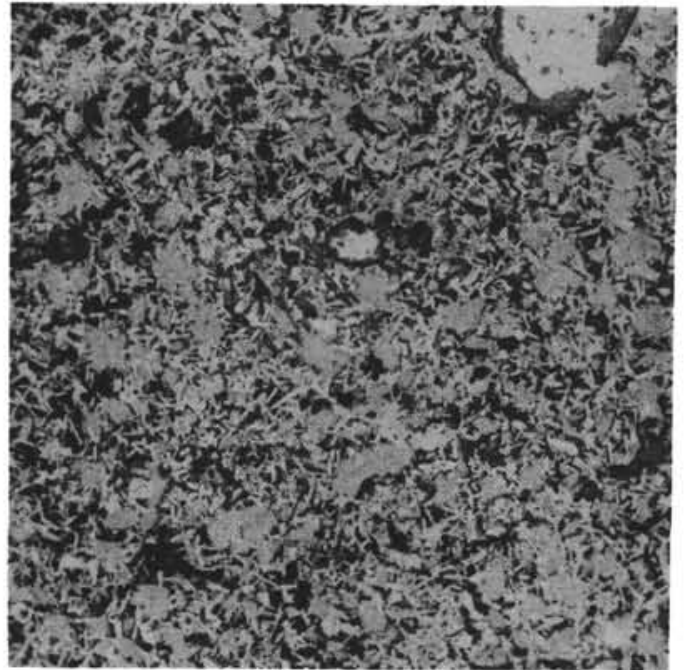

1
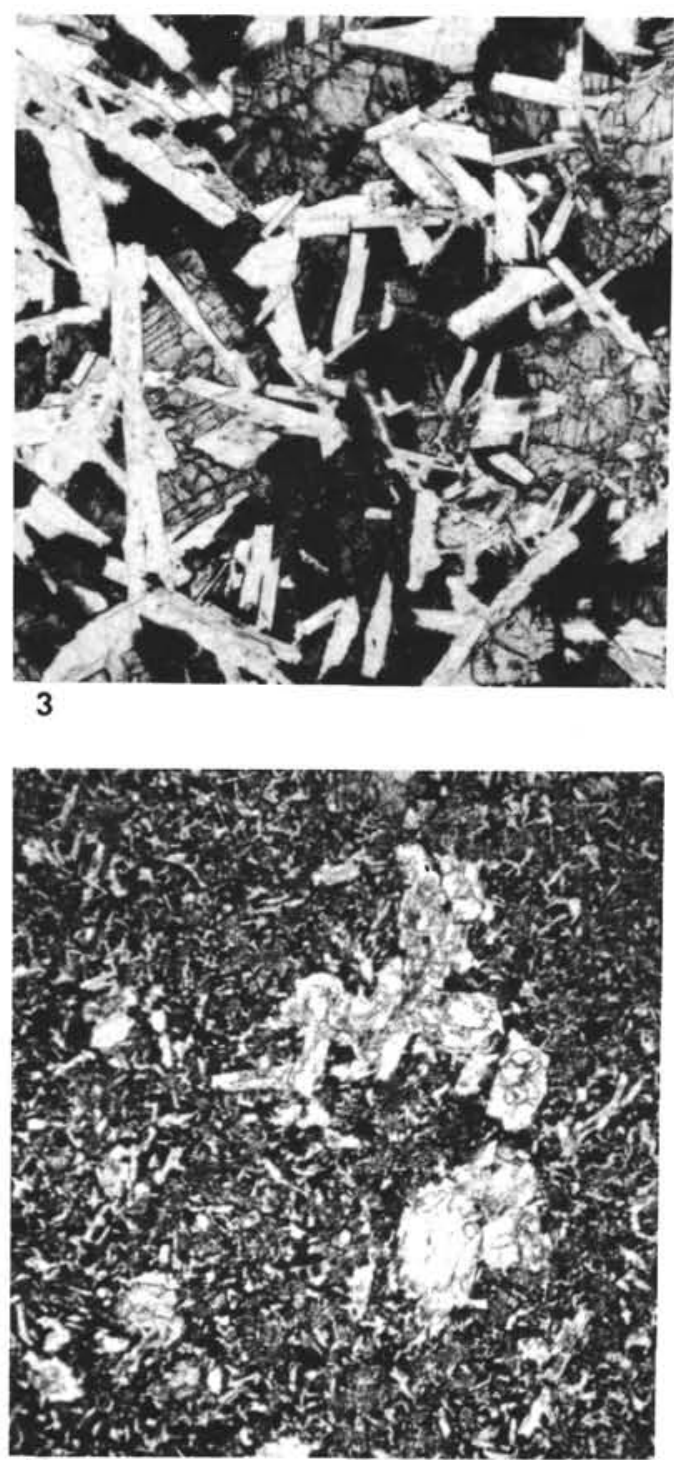

5

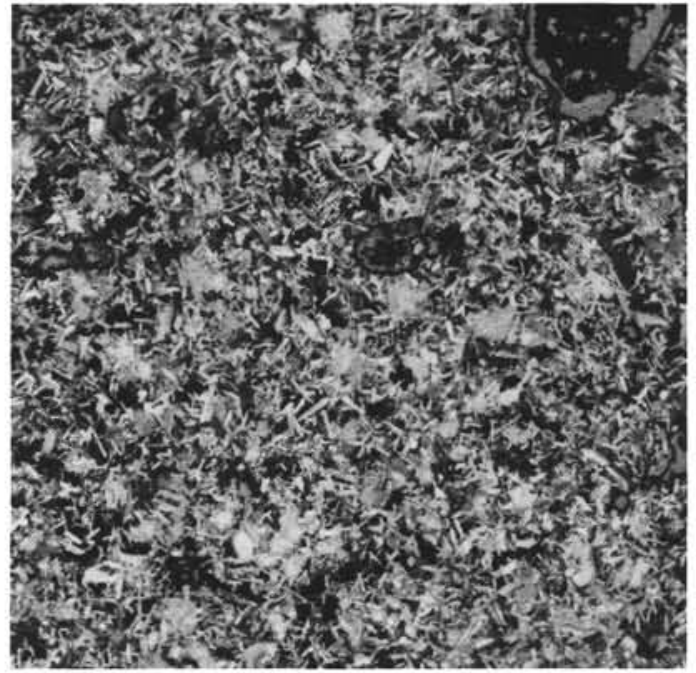

2
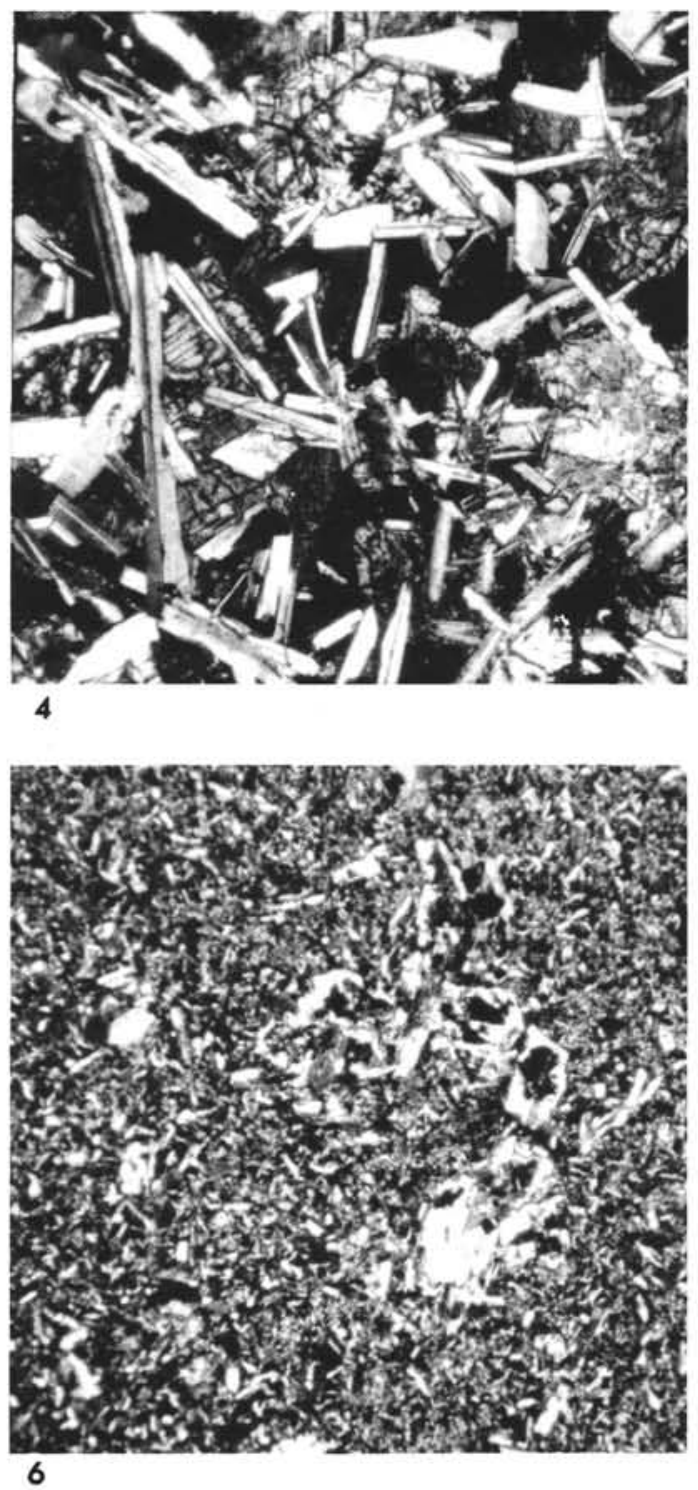


\section{PLATE 3}

Photographs and photomicrographs of rocks from Hole 317A.

Figure 1 Photograph of vesicles in Sample 317A-34-3, 75-79 $\mathrm{cm}$. Scale is $1 \mathrm{~cm}$. Vesicles range in size up to 20 $\mathrm{mm}$, although they average $5-6 \mathrm{~mm}$. They also form up to $30 \%$ of the rock. Vesicles in this sample are filled with heulandite. Flow Unit 10.

Figure 2 Another view of the same sample.

Figure 3 Photomicrograph of Sample 317A-34-3, 115-117 $\mathrm{cm}$. Horizontal dimension of slide is $20 \mathrm{~mm}$. Section cut in vertical plane of the core; notch marks up. Plane light. vesicles largely open, some have thin rims of green montmorillonite.

Figure $4 \quad$ Same as 3; crossed nicols. 


\section{PLATE 3}
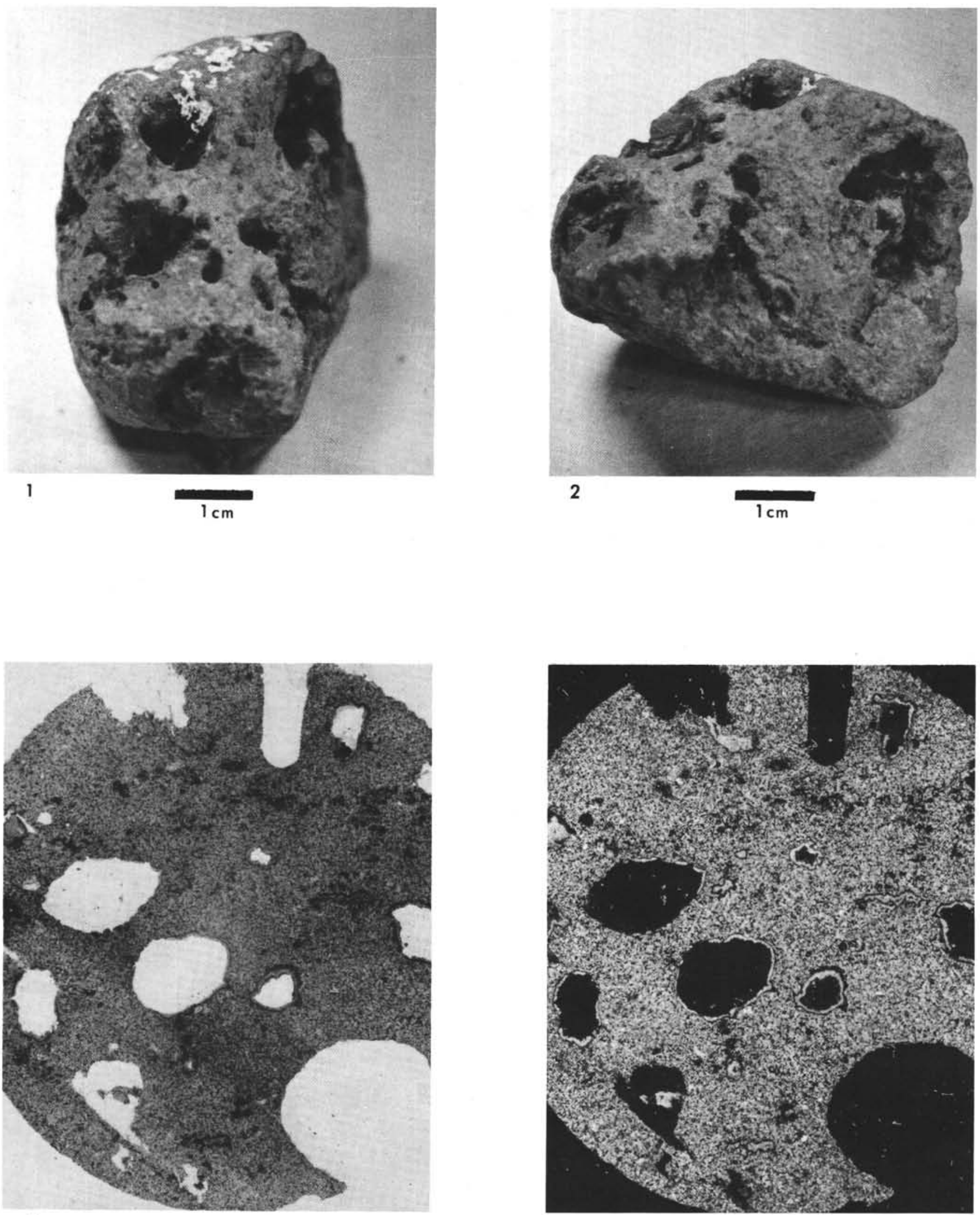

4 
TABLE 3

Petrographic Data for Sampled Basalts of Hole 315A

\begin{tabular}{|c|c|c|c|c|c|c|c|c|c|c|c|c|}
\hline \multirow[b]{2}{*}{$\begin{array}{c}\text { Sample } \\
\text { (Interval in cm) }\end{array}$} & \multicolumn{3}{|c|}{$\begin{array}{l}\text { Phenocrysts and } \\
\text { Microphenocrysts }^{\mathrm{a}}\end{array}$} & \multicolumn{3}{|c|}{ Vesicles $^{a}$} & \multicolumn{3}{|c|}{ Groundmass $^{\mathrm{a}}$} & \multirow[b]{2}{*}{ Alteration } & \multirow[b]{2}{*}{$\begin{array}{l}\text { Other } \\
\text { Work }\end{array}$} & \multirow[b]{2}{*}{ Remarks } \\
\hline & Mineral & Percent & $\begin{array}{c}\text { Average } \\
\text { Size (mm) }\end{array}$ & Percent & $\begin{array}{c}\text { Size } \\
\text { Range }\end{array}$ & \begin{tabular}{|c} 
Average \\
Size (mm)
\end{tabular} & Percent & \begin{tabular}{|c} 
Average \\
Size (mm)
\end{tabular} & $\begin{array}{c}\text { Dominant } \\
\text { Texture }\end{array}$ & & & \\
\hline $\begin{array}{l}\text { 30-2, 141.5-143.5 } \\
\text { (Flow Unit 1A) }\end{array}$ & $\begin{array}{l}\text { Plagioclase } \\
\text { Augite } \\
\text { Olivine }\end{array}$ & $\begin{array}{l}27.5 \\
10.0 \\
<1\end{array}$ & $\begin{array}{l}0.4 \times 1.5 \\
0.5 \\
0.5\end{array}$ & 1.5 & $0.1-1.0$ & 0.5 & 61.0 & $<0.2$ & Variolitic & $\begin{array}{l}\text { Heavily altered variolitic basalt; } \\
\text { plagioclase } 15-20 \% \text { altered to } \\
\text { montmorillonite; augite (probably } \\
\text { once } \sim 30 \% \text { of rock) almost entirely } \\
\text { altered to green montmorillonite; } \\
<1 \% 0.5 \mathrm{~mm} \text { grains of iddingsite } \\
\text { suggest the former presence of very } \\
\text { minor amounts of olivine; groundmass } \\
\text { appears to have been glass, now } \\
\text { entirely altered to brown mont- } \\
\text { morillonite; vesicles partly to wholly } \\
\text { filled; these have green montmorill- } \\
\text { onite rims and calcite interiors; } \\
\text { stained sections and X-ray data show } \\
\text { no nepheline or K-feldspar }\end{array}$ & $\begin{array}{l}\text { Sts (N) } \\
\text { Sts (K) } \\
\text { X (w.r.) } \\
\text { X (v.f.) }\end{array}$ & $\begin{array}{l}\text { Abundant (2-3\%) tiny }(0.05 \mathrm{~mm}) \\
\text { euhedral magnetite grains present } \\
\text { as inclusions in plagioclase } \\
\text { microphenocrysts and along } \\
\text { their boundaries }\end{array}$ \\
\hline $\begin{array}{l}\text { 31-1, 113-115 } \\
\text { (Flow Unit 1B) }\end{array}$ & $\begin{array}{l}\text { Plagioclase } \\
\text { Augite } \\
\text { Olivine }\end{array}$ & $\begin{array}{l}34.0 \\
12.5 \\
<1\end{array}$ & $\begin{array}{l}1.0 \times 3.0 \\
1.0\end{array}$ & 2.5 & $0.1-1.0$ & 0.5 & 61.0 & $<0.2$ & Variolitic & $\begin{array}{l}\text { A coarser and slightly fresher } \\
\text { variant of } 30-2,141.5-143.5 \text { augite, } \\
\text { and shapes are better preserved; } \\
\text { distribution of ilmenite microlites } \\
\text { suggests rock consisted of } \sim 10 \% \\
\text { glass now completely al tered; } X-\text { ray } \\
\text { shows minor amounts of pyrite and } \\
\text { anatase }\end{array}$ & $\begin{array}{l}\text { Sts (N) } \\
\text { Sts (K) } \\
\mathrm{X}(\mathrm{W} . \mathrm{r} .)\end{array}$ & $\begin{array}{l}\text { Same magnetite distribution as } \\
\text { above, but magnetites are } \\
\text { coarser - up to } 0.25 \mathrm{~mm}\end{array}$ \\
\hline $\begin{array}{l}\text { 31-1,115.5-117.5 } \\
\text { (Flow Unit 1B) }\end{array}$ & Identical to & $1-1,113-1$ & & & & & & & Variolitic & & $\begin{array}{l}\text { C.A. } \\
X(w . r) \\
X(v . f .) \\
\text { pts }\end{array}$ & $\begin{array}{l}\text { Polished section shows no } \\
\text { chromite; euhedral and skeletal } \\
\text { magnetite without ilmenite inter- } \\
\text { growths occurs; elongate skeletal } \\
\text { ilmenite partly altered to anatase, } \\
\text { a very small amount of chalco- } \\
\text { pyrite scattered through the rock }\end{array}$ \\
\hline $\begin{array}{l}\text { 31, CC } \\
\text { (Flow Unit 1B) }\end{array}$ & $\begin{array}{l}\text { Plagioclase } \\
\text { Augite } \\
\text { Olivine }\end{array}$ & $\begin{array}{l}27.0 \\
10.0 \\
<1\end{array}$ & $\begin{array}{l}0.4 \times 1.5 \\
0.5\end{array}$ & 2.0 & $0.1-0.5$ & 0.4 & 61.0 & $<0.2$ & Variolitic & $\begin{array}{l}\text { Same as } 30-2,141.5-143.5 \text { but lacks } \\
\text { altered olivine in available sections }\end{array}$ & $\begin{array}{l}\text { Sts (N) } \\
\text { Sts (K) } \\
X \text { (w.r.) } \\
X \text { (v.f.) }\end{array}$ & $\begin{array}{l}\text { Appears identical to } 30-2,141.5- \\
143.5 ; \text { considerably finer grained } \\
\text { than } 1,113-115 \text { and } 115.5-117.5\end{array}$ \\
\hline $\begin{array}{l}\text { 32-1, 139-141 } \\
\text { (Flow Unit 2) }\end{array}$ & Aphyric & - & - & 3.5 & $1.0-2.0$ & 1.5 & 96.5 & $<0.05$ & Vitrophyric & $\begin{array}{l}\text { Moderately altered vitrophyric basalt, } \\
\text { plagioclase in small random laths } \\
\text { somewhat altered to montmorillonite; } \\
\text { augite is stellate; also somewhat } \\
\text { altered to montmorillonite; formerly } \\
\text { very fine grained and glassy areas com- } \\
\text { pletely altered to brown and green } \\
\text { montmorillonite which also partially } \\
\text { fills vesicles; magnetite euhedra and } \\
\text { ilmenite skeletal laths abundant; no } \\
\text { calcite present; stained sections and } \\
\text { X-ray data show no nepheline or } \\
\text { K-feldspar }\end{array}$ & $\begin{array}{l}\text { Sts (N) } \\
\text { Sts (K) } \\
\text { X (w.r.) } \\
\text { X (v.f.) }\end{array}$ & \\
\hline $\begin{array}{l}\text { 32-1, 141.5-143.5 } \\
\text { (Flow Unit 2) }\end{array}$ & Same as $32-1$ & , 139-141 & & & & & & & & Somewhat fresher than $32-1,139-141$ & $\begin{array}{l}\text { C.A. } \\
X \text { (w.r.) } \\
\text { X (v.f.) } \\
\text { pts }\end{array}$ & $\begin{array}{l}\text { In reflected light "magnetite" } \\
\text { skeletal crystals and euhedra are } \\
\text { magnetite-ilmenite intergrowths; } \\
\text { ilmenite skeletal laths are also } \\
\text { present }\end{array}$ \\
\hline $\begin{array}{l}\text { 32-2, 79.5-80 } \\
\text { (Flow Unit 2) }\end{array}$ & Included in & escription & of $32-2,80-82$ & & & & & & & & pts & $\begin{array}{l}\text { In reflected light "magnetites" are } \\
\text { complex magnetite-ilmenite inter- } \\
\text { growths; bladed homogeneous } \\
\text { ilmenite also occurs; scattered } \\
\text { rounded grains of chalcopyrite and } \\
\text { veins of pyrite occur throughout } \\
\text { the rock }\end{array}$ \\
\hline
\end{tabular}




\begin{tabular}{|c|c|c|c|c|c|c|c|c|c|c|c|c|}
\hline $\begin{array}{l}\text { 32-2, 80-81 } \\
\text { (Flow Unit 2) }\end{array}$ & Included in & scription & f $32-2,80-82$ & & & & & & & & $\mathrm{~K} / \mathrm{A}$ (w.r.) & \\
\hline $\begin{array}{l}32-2,80-82 \\
\text { (Flow Unit 2) }\end{array}$ & $\begin{array}{l}\text { Plagioclase } \\
\text { Augite }\end{array}$ & $\begin{array}{r}38.5 \\
8.5\end{array}$ & $\begin{array}{l}0.4 \times 1.0 \\
0.5 \times 2.0\end{array}$ & 5.5 & $0.5-2.5$ & 1.5 & 47.5 & $<0.5$ & $\begin{array}{l}\text { Diabasic- } \\
\text { trachytic }\end{array}$ & $\begin{array}{l}\text { Moderately altered diabasic basalt; } \\
\text { plagioclase in stubby laths that tend } \\
\text { to be oriented parallel to core; } \\
\text { centers of some laths show mont- } \\
\text { morillonite alteration; a few augites } \\
\text { occur as microphenocrysts, remainder } \\
\text { diabasically enclose plagioclase; } \\
\text { groundmass pyroxene moderately } \\
\text { altered; very fine patches of ground- } \\
\text { mass pyroxene moderately altered; } \\
\text { very fine patches of groundmass } \\
\text { marked by feldspar and ilmenite } \\
\text { microlites completely altered to } \\
\text { brown montmorillonite; some vesicles } \\
\text { filled by green montmorillonite; } \\
\text { others filled with calcite }\end{array}$ & $\begin{array}{l}\text { Sts (N) } \\
\text { Sts (K) } \\
\mathrm{X}(\mathrm{wr.} .) \\
\mathrm{X}(\mathrm{v} . \mathrm{f} .)\end{array}$ & $\begin{array}{l}\text { Magnetite scattered quite evenly } \\
\text { through rock }\end{array}$ \\
\hline $\begin{array}{l}32-2,82.5-83.5 \\
\text { (Flow Unit 2) }\end{array}$ & $\begin{array}{l}\text { Plagioclase } \\
\text { Augite }\end{array}$ & $\begin{array}{r}20.5 \\
7.0\end{array}$ & $\begin{array}{l}0.4 \times 1.0 \\
0.5 \times 2.0\end{array}$ & 5.0 & $0.5-3.0$ & 1.5 & 67.5 & $<0.5$ & $\begin{array}{l}\text { Diabasic- } \\
\text { trachytic }\end{array}$ & $\begin{array}{l}\text { Identical to } 32-2,80-82 \text {. Calcite } \\
\text { detected in X-ray; not seen in thin } \\
\text { sections }\end{array}$ & $\begin{array}{l}\text { C.A. } \\
\text { pts } \\
\text { Sts(N) } \\
\text { Sts (K) } \\
\text { X (w.r.) } \\
\text { X (v.f.) }\end{array}$ & $\begin{array}{l}\text { In reflected light, same as } 32-2 \text {, } \\
79.5-80 \text { except magnetite is } \\
\text { pinker and shows less tendency to } \\
\text { exolve ilmenite }\end{array}$ \\
\hline $\begin{array}{l}32-2,83.5-91 \\
\text { (Flow Unit 2) }\end{array}$ & & & & & & & & & & $\mathrm{X}$-ray identical to $33-2,82.5-83.5$ & $\begin{array}{l}\text { K/A (pc) } \\
X(w . r .) \\
X(v . f .)\end{array}$ & \\
\hline $\begin{array}{l}32-2,95-96 \\
\text { (Flow Unit 2) }\end{array}$ & Same as 32-2 & $82.5-83.5$ & & & & & & & & $\begin{array}{l}\text { Same as } 32-2,82.5-83.5 \text { except that } \\
\text { pyrite grains as large as } 1 \mathrm{~mm} \text { occur } \\
\text { as vesicle fillings inside mont- } \\
\text { morillonite rims }\end{array}$ & $\begin{array}{l}\text { Sts }(\mathrm{N}) \\
\text { Sts (K) } \\
\text { X (w.r.) } \\
\text { X (v.f.) }\end{array}$ & \\
\hline $\begin{array}{l}\text { 32-2, 96-105 } \\
\text { (Flow Unit 2) }\end{array}$ & & & & & & & & & & $\begin{array}{l}\text { X-ray identical to } 33-2,80-82 \\
\text { and } 95-96\end{array}$ & $\begin{array}{l}\text { C.A. } \\
X \text { (w.r.) } \\
X(v . f .)\end{array}$ & \\
\hline $\begin{array}{l}32-2,105-106 \\
\text { (near base of } \\
\text { Flow Unit 2) }\end{array}$ & Aphyric & & & 5.5 & $0.5-3.0$ & 1.5 & 74.5 & $<0.5$ & $\begin{array}{l}\text { Diabasic- } \\
\text { trachytic }\end{array}$ & $\begin{array}{l}\text { Identical in mineral proportions, } \\
\text { texture, and alteration to } 32-1,139 \text { - } \\
141 \text {; finer grained but otherwise } \\
\text { identical to section from } 32-2,79.5 \text { - } \\
82,82.5-83.5 \text {, and } 95-96\end{array}$ & pts & $\begin{array}{l}\text { In reflected light similar to } \\
32-1,141.5-143.5 \text { except that } \\
\text { pyrite is more abundant, especially } \\
\text { as vesicle fillings }\end{array}$ \\
\hline $\begin{array}{l}32-3,7-9 \\
\text { (Flow Unit 3) }\end{array}$ & Aphyric & & & 8.5 & $1.0-4.0$ & 2.0 & 91.5 & $<0.5$ & Diabasic & $\begin{array}{l}\text { Moderately to heavily altered aphyric } \\
\text { diabasic basalt; plagioclases stubby, } \\
\text { slightly altered to montmorillonite in } \\
\text { central parts; interstitial augite about } \\
\text { half altered to montmorillonite; rock } \\
\text { is even-grained and appears to have } \\
\text { contained little glass; magnetite tends } \\
\text { to occur in interstices between plagio- } \\
\text { clase grains; ilmenite is concentrated } \\
\text { in pyroxene; vesicles are completely } \\
\text { filled with montmorillonite; pyrite is } \\
\text { locally abundant, replacing central } \\
\text { parts of vesicles; stained sections and } \\
\text { X-rays show no nepheline or } \mathrm{K} \text { - } \\
\text { feldspar }\end{array}$ & $\begin{array}{l}\text { Sts }(N) \\
\text { Sts (K) } \\
X(w . r .) \\
X(v . f .)\end{array}$ & \\
\hline $\begin{array}{l}32-3,9.5-11.5 \\
\text { (Flow Unit 3) }\end{array}$ & Same as 32-3 & & & & & & & & & Same as $32-3,7-9$ & $\begin{array}{l}\text { C.A. } \\
X(w . r .) \\
X(v . f .) \\
\text { pts }\end{array}$ & $\begin{array}{l}\text { "Magnetite" occurs as magnetite- } \\
\text { ilmenite intergrowths in euhedral } \\
\text { to skeletal cyrstals; ilmenite in } \\
\text { laths, mostly in pyroxene; } \\
\text { chalcopyrite in tiny rounded } \\
\text { grains throughout the rock; pyrite is } \\
\text { abundant in grains as large as } 1 \mathrm{~mm} \\
\text { in vesicles; in some cases it is } \\
\text { rimmed by platelets of hematite }\end{array}$ \\
\hline
\end{tabular}


TABLE 3 - Continued

\begin{tabular}{|c|c|c|c|c|c|c|c|c|c|c|c|c|}
\hline \multirow[b]{2}{*}{$\begin{array}{c}\text { Sample } \\
\text { (Interval in } \mathrm{cm} \text { ) }\end{array}$} & \multicolumn{3}{|c|}{$\begin{array}{l}\text { Pehnocrysts and } \\
\text { Microphenocrysts }^{\mathrm{a}}\end{array}$} & \multicolumn{3}{|c|}{ Vesicles $^{a}$} & \multicolumn{3}{|c|}{ Groundmass $^{\mathrm{a}}$} & \multirow[b]{2}{*}{ Alteration } & \multirow[b]{2}{*}{$\begin{array}{l}\text { Other } \\
\text { Work }\end{array}$} & \multirow[b]{2}{*}{ Remarks } \\
\hline & Mineral & Percent & \begin{tabular}{|c} 
Average \\
Size (mm) \\
\end{tabular} & Percent & $\begin{array}{c}\text { Size } \\
\text { Range }\end{array}$ & $\begin{array}{c}\text { Average } \\
\text { Size (mm) } \\
\end{array}$ & Percent & $\begin{array}{c}\text { Average } \\
\text { Size }(\mathrm{mm})\end{array}$ & $\begin{array}{c}\text { Dominant } \\
\text { Texture }\end{array}$ & & & \\
\hline $\begin{array}{l}\text { 32-3, 85-87 } \\
\text { (Flow Unit 3) }\end{array}$ & Aphyric & & & 9.5 & $0.5-3.0$ & 1.0 & 90.5 & $<0.5$ & Diabasic & $\begin{array}{l}\text { Appears identical in texture and } \\
\text { alteration to } 32-3,7-9 \text { except } \\
\text { slightly more vuggy, slightly coarser } \\
\text { grained, and calcite appears as a } \\
\text { vesicle-filling mineral }\end{array}$ & $\begin{array}{l}\text { Sts }(N) \\
\text { Sts (K) } \\
X(w . r .) \\
X(v . f .)\end{array}$ & $\begin{array}{l}\text { Marcasite identified in vesicle } \\
\text { filling by X-ray diffraction }\end{array}$ \\
\hline $\begin{array}{l}\text { 32-3, 87.5-89.5 } \\
\text { (Flow Unit 3) }\end{array}$ & Same as 32- & $85-87$ & & & & & & & & Same as $32-3,85-87$ & $\begin{array}{l}\text { C.A. } \\
X(w . r .) \\
X(v . f .) \\
\text { pts }\end{array}$ & $\begin{array}{l}\text { In reflected light is much like } \\
32-3,9.5-11.5 \text { except contains } \\
\text { much less pyrite as a vug filling } \\
\text { material }\end{array}$ \\
\hline $\begin{array}{l}\text { 32-4, 53-55 } \\
\text { (Flow Unit 4) }\end{array}$ & Aphyric & & & 9.0 & $0.2-2.0$ & 0.8 & 91.0 & $<0.5$ & $\begin{array}{l}\text { Diabasic- } \\
\text { intersertal }\end{array}$ & $\begin{array}{l}\text { Moderately altered diabasic- } \\
\text { intersertal baslat; plagioclases stubby, } \\
\text { little altered; augites diabasic, par- } \\
\text { tially altered to montmorillonite; } \\
\text { magnetite interstitial to plagioclase } \\
\text { laths; ilmenite not abundant, con- } \\
\text { centrated in patchy areas that appear } \\
\text { to have been glassy; all glassy material } \\
\text { altered to brown montmorillonite; } \\
\text { vesicles completely filled with green } \\
\text { and brown montmorillonite; no calcite } \\
\text { observed, but some pyrite occurs as } \\
\text { vesicle fillings; no nepheline or } \mathrm{K} \text { - } \\
\text { feldspar present }\end{array}$ & $\begin{array}{l}\text { K/A (w.r.) } \\
\text { pts } \\
X(w . r .) \\
X(v . f .)\end{array}$ & $\begin{array}{l}\text { In reflected light magnetite is } \\
\text { pinkish, and does not exsolve } \\
\text { ilmenite, but is intergrown with } \\
\text { unusual amounts of ulvospinel; } \\
\text { ilmenite occurs as sparse laths, } \\
\text { chalcopyrite is present as minor } \\
\text { blebs; pyrite is present as sparse } \\
\text { veins and occurs in one vesicle }\end{array}$ \\
\hline $\begin{array}{l}32-4,56-58 \\
\text { (Flow Unit 4) }\end{array}$ & Same as 32 & $53-55$ & & & & & & & & $\begin{array}{l}\text { Same as } 324.53-55 \text {, but somewhat } \\
\text { fewer formerly glassy areas and } \\
\text { fresher }\end{array}$ & $\begin{array}{l}\text { Sts (N) } \\
\text { Sts (K) } \\
\text { X (w.r.) } \\
\text { X (v.f.) }\end{array}$ & \\
\hline $\begin{array}{l}32-4,59-61 \\
\text { (Flow Unit 4) }\end{array}$ & Same as 32 & $53-55$ & & & & & & & & $\begin{array}{l}\text { Same as } 32-4,56-58, \text { but contains } \\
\text { more calcite }\end{array}$ & $\begin{array}{l}\text { C.A. } \\
X(w . r .) \\
X(v . f .) \\
\text { pts }\end{array}$ & $\begin{array}{l}\text { In reflected light same as } \\
32-4,53-55, \text { but contains more } \\
\text { chalcopyrite and pyrite }\end{array}$ \\
\hline $\begin{array}{l}32-4,149-150 \\
\text { (Flow Unit 4) }\end{array}$ & Same as 32 & $56-58$ & & & & & & & & Same as $324.59-61$ & $\begin{array}{l}\text { Sts (N) } \\
\text { Sts (K) }\end{array}$ & \\
\hline $\begin{array}{l}33-1,116.5-118.5 \\
\text { (Flow Unit 5A) }\end{array}$ & Same as 33 . & $121-123$ & elow & & & & & & & & $\begin{array}{l}\text { C.A. } \\
X(w . r .) \\
X(v . f .) \\
\text { pts }\end{array}$ & $\begin{array}{l}\text { In reflected light very tiny }(0.01) \\
\text { mm octahedra of magnetite } \\
\text { exsolving ulvospinel; some tiny } \\
\text { laths of ilmenite; very minor } \\
\text { amounts of sulfides seen in } \\
\text { sections }\end{array}$ \\
\hline $\begin{array}{l}\text { 33-1, 121-123 } \\
\text { (Flow Unit 5A) }\end{array}$ & Aphyric & & & 2.0 & $0.1-1.0$ & 0.5 & 98.0 & $<0.2$ & Vitrophyric & $\begin{array}{l}\text { Heavily altered vitrophyric basalt; } \\
\text { plagioclase in tiny }(0.05 \times 0.5 \mathrm{~mm}) \\
\text { laths, unaltered; augite present in very } \\
\text { small amounts and almost completely } \\
\text { altered to montmorillonite; opaque } \\
\text { oxides very tiny and scattered } \\
\text { throughout the rock; apparently the } \\
\text { rock consisted of nearly } 40 \% \text { glass is } \\
\text { now completely altered to mont- } \\
\text { morillonite; no nepheline or } \mathrm{K}- \\
\text { feldspar present; all vesicles were } \\
\text { filled with calcite }\end{array}$ & $\begin{array}{l}\text { Sts (N) } \\
\text { Sts (K) } \\
X \text { (w.r.) } \\
X(v . f .)\end{array}$ & . \\
\hline $\begin{array}{l}\text { 33, CC } \\
\text { (Flow Unit 5A) }\end{array}$ & Same as 33- & $121-123$ & & & & & & & & $\begin{array}{l}\text { Much like } 33-1,121-123 \text {, but slightly } \\
\text { coarser; plagioclase laths average } 0.4 \\
\times 0.6 \mathrm{~mm} \text { and augite is present as } \\
0.4 \times 0.8 \text { laths and stubby crystals; } \\
\text { pyroxene is less altered than } 121-123\end{array}$ & $\begin{array}{l}\text { Sts }(\mathrm{N}) \\
\text { Sts (K) } \\
\text { X (w.r.) } \\
\text { X (v.f.) }\end{array}$ & \\
\hline
\end{tabular}




\begin{tabular}{|c|c|c|c|c|c|c|c|c|c|c|}
\hline $\begin{array}{l}\text { 34-1, 71-73 } \\
\text { (Flow Unit 6) }\end{array}$ & $\begin{array}{l}\text { Aphyric to micro- } \\
\text { phenocrysts of } \\
\text { plagioclase and } \\
\text { augite }\end{array}$ & 7.5 & $0.2-1.0$ & 0.5 & 92.5 & $<0.5$ & $\begin{array}{l}\text { Intersertal- } \\
\text { diabasic }\end{array}$ & $\begin{array}{l}\text { Moderately altered intersertal- } \\
\text { diabasic basalt; plagioclases seriate } \\
\text { from } 0.05 \times 0.5 \text { mm to } 0.5 \times 3 \mathrm{~mm} \text {; } \\
\text { slightly altered to montmorillonite } \\
\text { in centers; augite is mostly diabasically } \\
\text { enclosing the plagioclase, partly as } \\
\text { stubby } 0.3 \mathrm{~mm} \text { crystals almost com- } \\
\text { pletely altered to montmorillonite; } \\
\text { perhaps } 20 \% \text { of rock was glassy, } \\
\text { intersertal; now is completely altered; } \\
\text { opaques are scattered rather evenly } \\
\text { through the rock; vesicles completely } \\
\text { filled with montmorillonite and } \\
\text { calcite; no nepheline or K-feldspar is } \\
\text { observed }\end{array}$ & \begin{tabular}{|l|} 
Sts (N) \\
Sts (K) \\
X (w.r.) \\
X (v.f.)
\end{tabular} & \\
\hline $\begin{array}{l}\text { 34-1, 173.5-75.5 } \\
\text { (Flow Unit 6) }\end{array}$ & Same as $34-1,71-73$ & & & & & & & 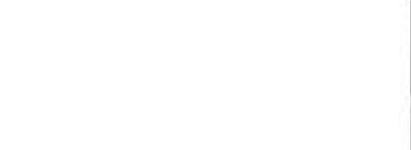 & $\begin{array}{l}\text { C.A. } \\
\text { X (w.r.) } \\
\text { X (v.f.) } \\
\text { pts }\end{array}$ & $\begin{array}{l}\text { In reflected light magnetite } \\
\text { exsolves ulvospinel, ilmenite laths } \\
\text { are localized in formerly glassy } \\
\text { areas; chalcopyrite is present but } \\
\text { not abundant }\end{array}$ \\
\hline $\begin{array}{l}\text { 34-1, 99-101 } \\
\text { (Flow Unit 6) }\end{array}$ & Same as $34-1,71-73$ & & & & & & & $\begin{array}{l}\text { Same as } 31-1,71-73 \text { and } 73.5-75.5 \\
\text { except more calcite is present as veins } \\
\text { and,pyrite occurs as a vesicle-filling } \\
\text { material }\end{array}$ & $\begin{array}{l}\text { K/A (w.r.) } \\
\text { pts } \\
\text { Sts (N) } \\
\text { Sts (K) } \\
\text { X ( (w.r.) } \\
\text { X (v.f.) }\end{array}$ & $\begin{array}{l}\text { Same as 34-1, } 73.5-75.5 \text { except } \\
\text { some anatase present as alteration } \\
\text { of ilmenite; } X \text {-ray determination } \\
\text { of plagioclase: } 68.6\end{array}$ \\
\hline $\begin{array}{l}\text { 34, CC } \\
\text { (Flow Unit 6) }\end{array}$ & Aphyric & 7.5 & $0.2-9.0$ & 0.5 & 92.5 & $<0.2$ & Vitrophyric & $\begin{array}{l}\text { Plagioclases are very fine-grained } \\
(0.01-0.5 \mathrm{~mm}) \text { appear unaltered; no } \\
\text { pyroxene remains in section; original } \\
\text { material appears to have been largely } \\
\text { glass, is now completely altered to } \\
\text { montmorillonite; vesicles now appear } \\
\text { to be completely filled by calcite }\end{array}$ & $\begin{array}{l}\text { Sts (N) } \\
\text { Sts (K) } \\
\text { X (w.r.) }\end{array}$ & \\
\hline
\end{tabular}

${ }^{a}$ Average points counted 300 ; percentages rounded to nearest $0.5 \%$.

$\mathrm{b}_{\text {Sts }}(\mathrm{N})=$ section stained for nepheline and melilite;

Sts $(K)=$ section stained for potassic feldspar;

$X(v . f)=$. vesicle filling $X$-ray diffraction pattern;
$X(w . r$.

C.A. = chemical analysis;

pts = polished thin section;

$\mathrm{K} / \mathrm{A}(\mathrm{p} . \mathrm{c})=$. potassium argon age on separated plagioclase. 
TABLE 4

Petrographic Data for Sampled Basalts of Hole 317A

\begin{tabular}{|c|c|c|c|c|c|c|c|c|c|c|c|c|}
\hline \multirow[b]{2}{*}{$\begin{array}{c}\text { Sample } \\
\text { (Interval in } \mathrm{cm} \text { ) }\end{array}$} & \multicolumn{3}{|c|}{$\begin{array}{l}\text { Phenocrysts and } \\
\text { Microphenocrysts }^{a}\end{array}$} & \multicolumn{3}{|c|}{ Vesicles $^{a}$} & \multicolumn{3}{|c|}{ Groundmass $^{a}$} & \multirow[b]{2}{*}{ Alteration } & \multirow[b]{2}{*}{$\begin{array}{l}\text { Other } \\
\text { Work }\end{array}$} & \multirow[b]{2}{*}{ Remarks } \\
\hline & Mineral & Percent & $\begin{array}{c}\text { Average } \\
\text { Size (mm) }\end{array}$ & Percent & $\begin{array}{c}\text { Size } \\
\text { Range }\end{array}$ & $\begin{array}{c}\text { Average } \\
\text { Size (mm) }\end{array}$ & Percent & $\begin{array}{l}\text { Average } \\
\text { Size (mm) }\end{array}$ & $\begin{array}{l}\text { Dominant } \\
\text { Texture }\end{array}$ & & & \\
\hline $\begin{array}{l}\text { 31-1, 141-143 } \\
\text { (Flow Unit 1) }\end{array}$ & $\begin{array}{l}\text { Plagioclase } \\
\text { Augite }\end{array}$ & $\begin{array}{l}1.0 \\
1.5\end{array}$ & $\begin{array}{l}0.4 \times 1.0 \\
0.6\end{array}$ & 24.5 & $0.5-10.0$ & 2.0 & 73.0 & $<0.1$ & $\begin{array}{l}\text { Diabasic- } \\
\text { intersertal }\end{array}$ & $\begin{array}{l}\text { Moderately altered basalt; plagioclase } \\
\text { microphenocrysts almost entirely } \\
\text { altered to montmorillonite, ground- } \\
\text { mass plagioclase partly altered; augite } \\
\text { microphenocrysts fresh, groundmass } \\
\text { pyroxene consists of augite and Ca- } \\
\text { poor augite slightly altered to mont- } \\
\text { morillonite; part of the groundmass } \\
\text { appears to have been glassy, intersertal, } \\
\text { but now is completely altered to } \\
\text { brown montmorillonite; vesicles are } \\
\text { partially to completely filled with } \\
\text { green montmorillonite; no nepheline } \\
\text { or K-feldspar observed }\end{array}$ & $\begin{array}{l}\text { Sts (N) } \\
\text { Sts (K) } \\
\text { X (W.r.) } \\
\text { X (v.f.) }\end{array}$ & \\
\hline $\begin{array}{l}31-1,144-146 \\
\text { (Flow Unit 1) }\end{array}$ & Same as $31-1$, & $1-143$ & & & & & & & & & $\begin{array}{l}\text { pts } \\
\text { C.A. } \\
X(\text { w.r. }) \\
X(v . f .)\end{array}$ & $\begin{array}{l}\text { In reflected light tiny skeletal } \\
\text { magnetites scattered evenly } \\
\text { through rock; some apparently } \\
\text { altered by an opaque nonreflec- } \\
\text { tive material; ilmenite laths pre- } \\
\text { sent but not abundant; chalco- } \\
\text { pyrite present as tiny spheres and } \\
\text { veinlets, in some cases intergrown } \\
\text { with pyrnhotite }\end{array}$ \\
\hline $\begin{array}{l}31-2,34-36 \\
\text { (Flow Unit 2) }\end{array}$ & Augite & 6.5 & 0.5 & 29.5 & $0.5-10.0$ & 2.5 & 64.0 & $<0.1$ & Diabasic & $\begin{array}{l}\text { Heavily altered basalt; only the } \\
\text { pyroxene microphenocrysts escape } \\
\text { rather extensive montmorillonite } \\
\text { alteration; no plagioclase micro- } \\
\text { phenocrysts; part of the groundmass } \\
\text { plagioclase and most of the ground- } \\
\text { mass pyroxene is altered; vesicles } \\
\text { filled with green montmorillonite; } \\
\text { no nepheline or K-feldspar }\end{array}$ & $\begin{array}{l}\text { Sts }(N) \\
\text { Sts (K) } \\
X(\mathrm{~W} . \mathrm{r}) \\
\mathrm{X}(\mathrm{v} . \mathrm{f} .)\end{array}$ & $\begin{array}{l}\text { Very similar to 31-1, 141-143 } \\
\text { except for increased micropheno- } \\
\text { cryst content and somewhat } \\
\text { greater degree of alteration of rock }\end{array}$ \\
\hline $\begin{array}{l}\text { 31-2, 37-39 } \\
\text { (Flow Unit 2) }\end{array}$ & Augite & 6.0 & 0.5 & 30.0 & $0.5-10.0$ & 3.0 & 64.0 & $<0.1$ & Diabasic & $\begin{array}{l}\text { Moderately altered basalt; most of the } \\
\text { groundmass plagioclase is fresh; pyrox- } \\
\text { ene microphenocrysts are unaltered; } \\
\text { groundmass pyroxene consisted of } \\
\text { augite and Ca-poor augite and is } \\
\text { partially altered to montmorillonite; } \\
\text { vesicles as in } 31-2,34-36 ; \text { contained } \\
\text { less glass than } 31-1,141-143\end{array}$ & $\begin{array}{l}\text { pts } \\
\text { C.A. } \\
X \text { (w.r.) } \\
X \text { (v.f.) }\end{array}$ & $\begin{array}{l}\text { Very similar to } 31-1,141-143 \\
\text { except that the microphenocryst } \\
\text { count remains high like } 31-2 \text {, } \\
34-36 \text {, but rock is much fresher; } \\
\text { in reflected light is similar to } 31-1 \text {, } \\
144-146 \text {, but several grains of red- } \\
\text { brown chromite observed }\end{array}$ \\
\hline $\begin{array}{l}\text { 31-3, 24-26 } \\
\text { (Flow Unit 3) }\end{array}$ & Augite & 11.5 & 0.7 & 5.0 & $0.3-1.5$ & 0.5 & 83.5 & $<0.3$ & Intersertal & $\begin{array}{l}\text { Somewhat altered basalt; augite } \\
\text { microphenocrysts fresh; groundmass } \\
\text { pyroxene consists of augite and Ca- } \\
\text { poor augite largely unaltered; } \text { ground- } \\
\text { mass plagioclase appears fresh, but all } \\
\text { former intersertal glass in groundmass } \\
\text { has been altered to brown mont- } \\
\text { morillonite; vigs less abundant than } \\
\text { Flow Units } 1 \text { and 2, lined with dark } \\
\text { brown montmorillonite, and par- } \\
\text { tially filled with green montmor- } \\
\text { illonite; a few round vesicles are } \\
\text { filled only with calcite; no nepheline } \\
\text { or K-feldspar present }\end{array}$ & $\begin{array}{l}\text { Sts (N) } \\
\text { Sts (K) } \\
X(\mathrm{w} . \mathrm{r}) \\
\mathrm{X}(\mathrm{v} . \mathrm{f} .)\end{array}$ & \\
\hline $\begin{array}{l}\text { 31-3, 27-29 } \\
\text { (Flow Unit 3) }\end{array}$ & Same as 31-3, & & & & & & & & & & $\begin{array}{l}\text { pts } \\
\text { C.A. } \\
X(w . r) \\
X(v . f .)\end{array}$ & $\begin{array}{l}\text { In reflected light magnetite is } \\
\text { scattered evenly through the rock } \\
\text { some apparently altered by an } \\
\text { opaque nonreflective material; } \\
\text { ilmenite is sparse and occurs as } \\
\text { rare laths; chalcopyrite occurs } \\
\text { as tiny blebs and lines some vesi- } \\
\text { cle walls; some is intergrown with } \\
\text { pyrrhotite }\end{array}$ \\
\hline
\end{tabular}




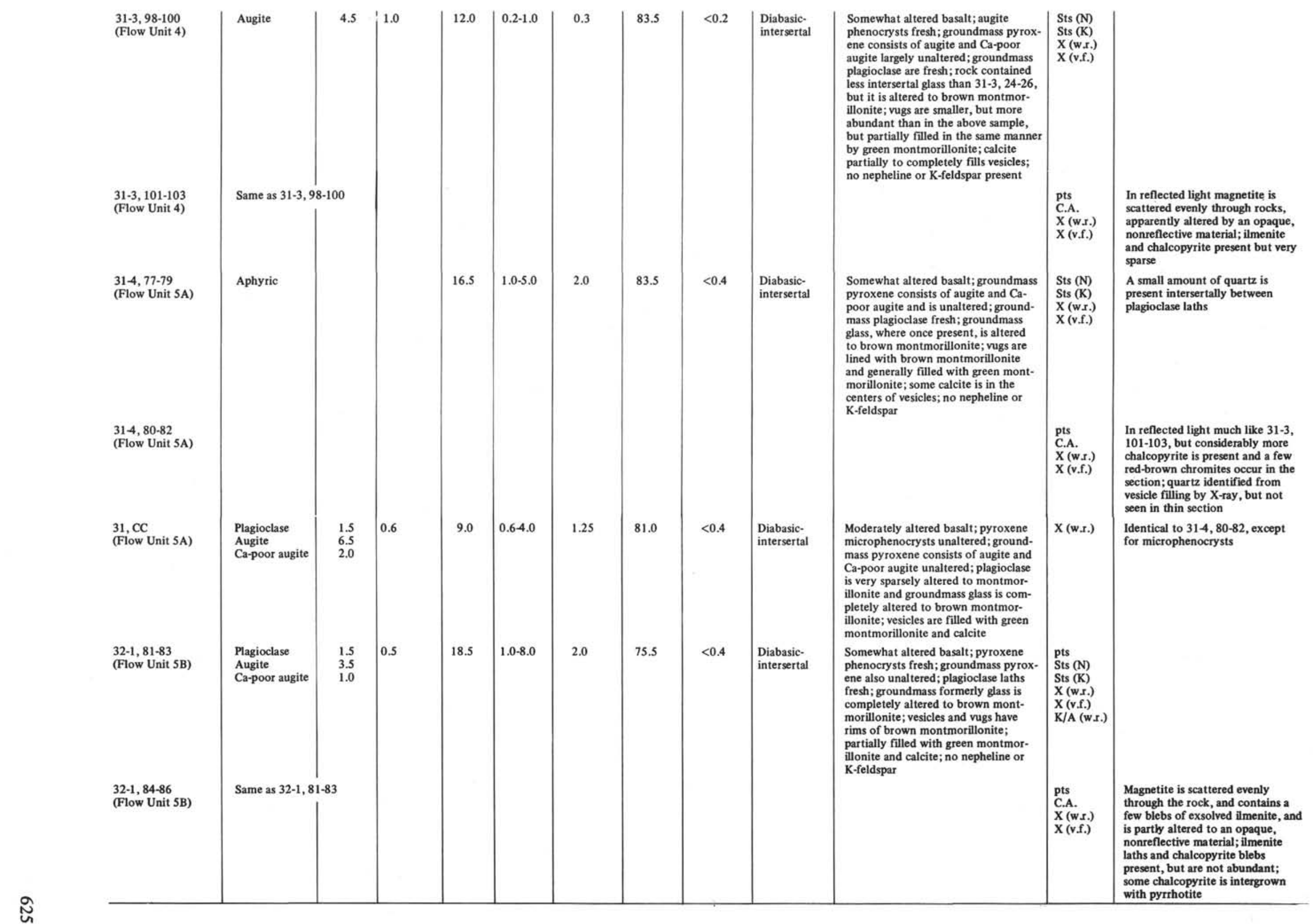


TABLE 4 - Continued

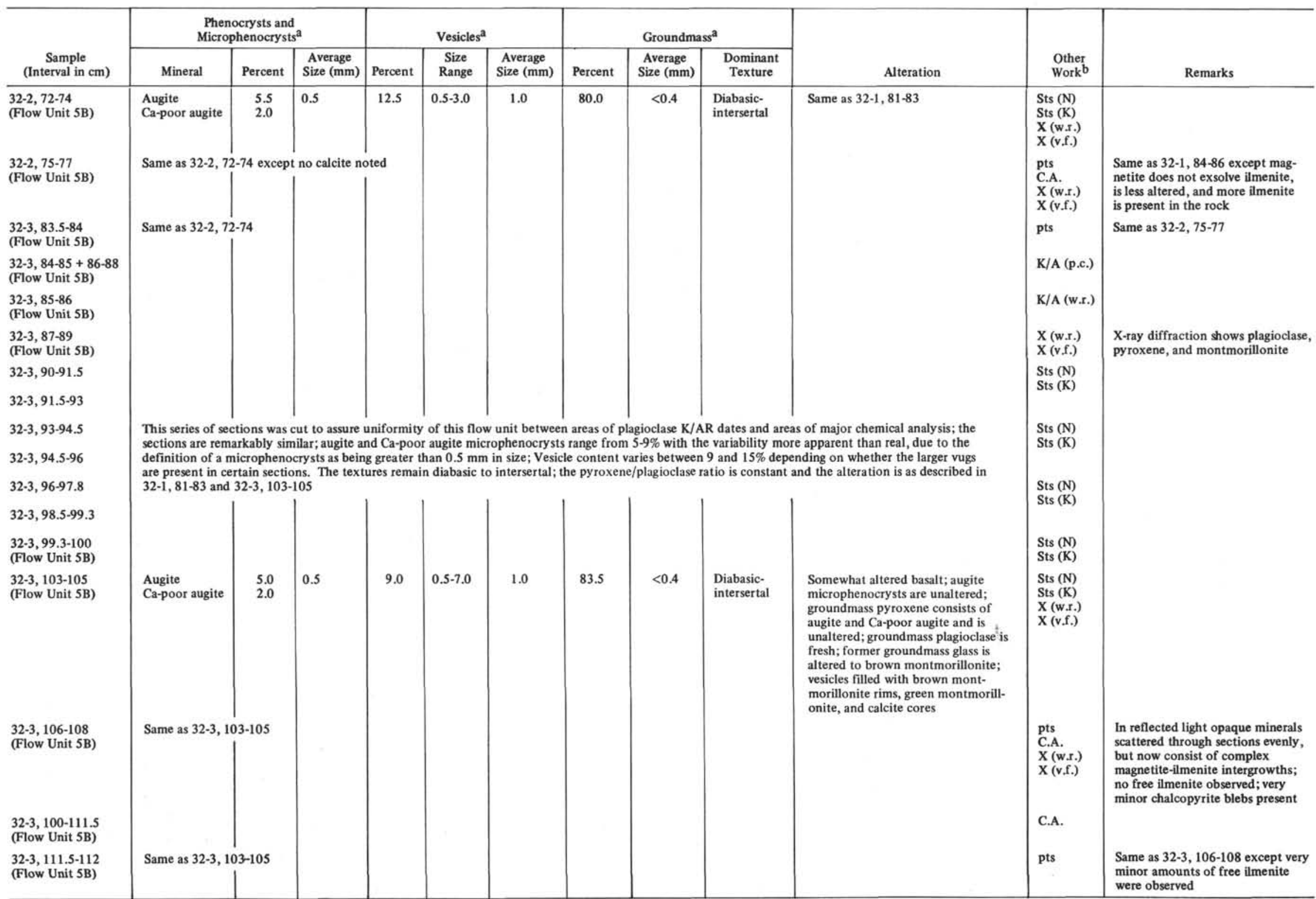




\begin{tabular}{|c|c|c|c|c|c|c|c|c|c|c|}
\hline $\begin{array}{l}\text { 32-4, 73-75 } \\
\text { (Flow Unit 5B) }\end{array}$ & Aphyric & 23.5 & $1.0-10.0$ & 6.0 & 76.5 & $<0.2$ & $\begin{array}{l}\text { Intersertal } \\
\text { diabasic }\end{array}$ & $\begin{array}{l}\text { Moderately altered basalt; ground- } \\
\text { mass pyroxene (augite and Ca.poor } \\
\text { augite) and plagioclase are slightly } \\
\text { altered to montmorillonite. Former } \\
\text { intersertal glass is much more abun- } \\
\text { dant than in previous sections of this } \\
\text { flow unit, completely altered to } \\
\text { montmorillonite; vugs are very large } \\
\text { and altered to montmorillonite and } \\
\text { calcite }\end{array}$ & $\begin{array}{l}\text { Sts (N) } \\
\text { Sts (K) } \\
\text { X (w.r.) } \\
\text { X (v.f.) }\end{array}$ & \\
\hline $\begin{array}{l}\text { 32-4, 76-78 } \\
\text { (Flow Unit 5B) }\end{array}$ & & & & & & & & & $\begin{array}{l}\text { pts } \\
\text { C.A. } \\
X(w . r .) \\
X(v . f .)\end{array}$ & $\begin{array}{l}\text { In reflected light magnetite is } \\
\text { scattered evenly through the rock, } \\
\text { very little exsolving ilmenite; mag- } \\
\text { netite is partly altered to opaque, } \\
\text { nonreflective material; ilmenite } \\
\text { blades and chalcopyrite blebs are } \\
\text { very sparse }\end{array}$ \\
\hline $\begin{array}{l}\text { 32-4, 123-125 } \\
\text { (Flow Unit 6A) }\end{array}$ & Aphyric & 6.0 & $0.5 \cdot 2.0$ & 1.0 & 94.0 & $<0.4$ & $\begin{array}{l}\text { Diabasic- } \\
\text { intersertal }\end{array}$ & $\begin{array}{l}\text { Somewhat altered basalt; groundmass } \\
\text { pyroxene (augite and Ca-poor augite) } \\
\text { feldspar fresh; former intersertal glass } \\
\text { is somewhat less abundant than in } \\
\text { Flow Unit } 5 \text {, but completely altered } \\
\text { to brown montmorillonite; vesicles } \\
\text { are filled with green montmorillonite; } \\
\text { no calcite seen in X-ray diffraction or } \\
\text { optically; no nepheline or X-Feldspar }\end{array}$ & $\begin{array}{l}\text { Sts (N) } \\
\text { Sts (K) } \\
\text { X (w.r.) } \\
\text { X (v.f.) }\end{array}$ & \\
\hline $\begin{array}{l}\text { 32-4, 126-128 } \\
\text { (Flow Unit 6A) }\end{array}$ & Same as $32-4,123-125$ & & & & & & & 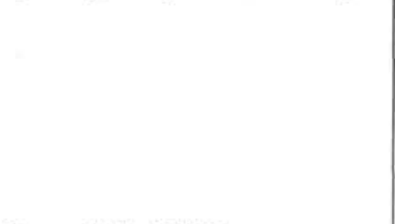 & $\begin{array}{l}\text { pts } \\
\text { C.A. } \\
X(\text { w.r. })\end{array}$ & $\begin{array}{l}\text { In reflected light complex } \\
\text { magnetite-ilmenite intergrowths } \\
\text { are scattered evenly throughout } \\
\text { the rock; a very few ilmenite laths } \\
\text { are seen in formerly glassy areas; } \\
\text { very sparse tiny blebs of chalco- } \\
\text { pyrite; some are intergrown with } \\
\text { pyrrhotite }\end{array}$ \\
\hline $\begin{array}{l}\text { 32-5, 92-94 } \\
\text { (Flow Unit 6A) }\end{array}$ & Aphyric & 6.0 & $0.5-2.0$ & 1.0 & 94.0 & $<0.4$ & $\begin{array}{l}\text { Diabasic- } \\
\text { intersertal }\end{array}$ & Same as $32-4,123-125$ & $\begin{array}{l}\text { Sts (N) } \\
\text { Sts (K) } \\
X(w . r .) \\
X(v . f .)\end{array}$ & \\
\hline $\begin{array}{l}\text { 32-5, 95-97 } \\
\text { (Flow Unit 6A) }\end{array}$ & Same as 32-5, 92-94 & & & & & & & & $\begin{array}{l}\text { pts } \\
\text { C.A. } \\
\text { X (w.r.) }\end{array}$ & Same as $32-4,126-128$ \\
\hline $\begin{array}{l}\text { 32-5, 103-105 } \\
\text { (Flow Unit 6A) }\end{array}$ & & & & & & & & & $X(w . r)$. & $\begin{array}{l}\text { X-ray diffraction pattern shows } \\
\text { plagioclase pyroxene, magnetite, } \\
\text { and montmorillonite }\end{array}$ \\
\hline $\begin{array}{l}\text { 32-6, 110-112 } \\
\text { (Flow Unit 6A) }\end{array}$ & Aphyric & 10.5 & $0.5-2.0$ & 1.0 & 89.5 & $<0.4$ & $\begin{array}{l}\text { Diabasic- } \\
\text { intersertal }\end{array}$ & $\begin{array}{l}\text { Same as } 32-4,123-125 \text {, but slightly } \\
\text { more vesicular; in addition, the } \\
\text { amount of altered intersertal glass is } \\
\text { somewhat less }\end{array}$ & $\begin{array}{l}\text { Sts }(\mathrm{N}) \\
\text { Sts (K) } \\
\mathrm{X}(\mathrm{w.r.})\end{array}$ & \\
\hline $\begin{array}{l}\text { 32-6, 113-115 } \\
\text { (Flow Unit 6A) }\end{array}$ & Same as $32-6,110-112$ & & & & & & & & $\begin{array}{l}\text { pts } \\
\text { C.A. } \\
\text { X (w.r.) } \\
\text { X (v.f.) }\end{array}$ & Same as $32-4,126-128$ \\
\hline $\begin{array}{l}\text { 32-6, 115-117 } \\
\text { (Flow Unit 6A) }\end{array}$ & Aphyric & 10.5 & $0.5-2.0$ & 1.0 & 89.5 & $<0.4$ & $\begin{array}{l}\text { Diabasic- } \\
\text { intersertal }\end{array}$ & $\begin{array}{l}\text { Same as } 32-6,110-112 \text {; vesicles are } \\
\text { more abundant in this part of the } \\
\text { flow unit and the amount of altered } \\
\text { intersertal glass is }<5 \% \text {. }\end{array}$ & $\begin{array}{l}\text { pts } \\
X \text { (w.r.) } \\
X(v . f .) \\
K / A \text { (w.r.) }\end{array}$ & $\begin{array}{l}\text { X-ray determination of plagioclass; } \\
\text { average composition is An } 73.5\end{array}$ \\
\hline $\begin{array}{l}\text { 32, CC } \\
\text { (Flow Unit 6A) }\end{array}$ & Aphyric & 8.5 & $0.5-2.0$ & 1.0 & 91.5 & $<0.4$ & $\begin{array}{l}\text { Diabasic- } \\
\text { intersertal }\end{array}$ & $\begin{array}{l}\text { Same as } 32-6,115-117 \text {, but small } \\
\text { calcite vein cuts sample; calcite also } \\
\text { follows some vesicle walls and } \\
\text { occurs as replacement patches locally }\end{array}$ & $X(w . r)$. & \\
\hline $\begin{array}{l}\text { 33-1, 37-39 } \\
\text { (Flow Unit 6B) }\end{array}$ & & & & & & & & & $X(w . r)$. & $\begin{array}{l}\text { X-ray diffraction pattern shows } \\
\text { plagioclase, pyroxene, and } \\
\text { montmorillonite }\end{array}$ \\
\hline
\end{tabular}


TABLE 4 - Continued

\begin{tabular}{|c|c|c|c|c|c|c|c|c|c|c|c|c|}
\hline \multirow[b]{2}{*}{$\begin{array}{c}\text { Sample } \\
\text { (Interval in cm) }\end{array}$} & \multicolumn{3}{|c|}{$\begin{array}{l}\text { Phenocrysts and } \\
\text { Microphenocrysts }\end{array}$} & \multicolumn{3}{|c|}{ Vesicles $^{a}$} & \multicolumn{3}{|c|}{ Groundmass $^{\mathrm{a}}$} & \multirow[b]{2}{*}{ Alteration } & \multirow[b]{2}{*}{$\begin{array}{l}\text { Other } \\
\text { Workb }\end{array}$} & \multirow[b]{2}{*}{ Remarks } \\
\hline & Mineral & Percent & $\begin{array}{c}\text { Average } \\
\text { Size }(\mathrm{mm})\end{array}$ & Percent & $\begin{array}{c}\text { Size } \\
\text { Range }\end{array}$ & $\begin{array}{c}\text { Average } \\
\text { Size }(\mathrm{mm})\end{array}$ & Percent & $\begin{array}{c}\text { Average } \\
\text { Size }(\mathrm{mm})\end{array}$ & $\begin{array}{c}\text { Dominant } \\
\text { Texture }\end{array}$ & & & \\
\hline $\begin{array}{l}\text { 33-1, 135-137 } \\
\text { (Flow Unit 6B) }\end{array}$ & Aphyric & & & 8.5 & $0.5-2.0$ & 1.0 & 91.5 & $<0.4$ & $\begin{array}{l}\text { Diabasic- } \\
\text { intersertal }\end{array}$ & $\begin{array}{l}\text { Somewhat altered basalt; groundmass } \\
\text { pyroxene (augite and Ca-poor augite) } \\
\text { and feldspar fresh; former groundmass } \\
\text { glass }(\sim 5 \%) \text { altered to brown mont- } \\
\text { morillonite; vesicles are filled with } \\
\text { green montmorillonite; no calcite is } \\
\text { seen in the section or X-ray diffrac- } \\
\text { tion pattern; no nepheline or } \\
\text { K-feldspar }\end{array}$ & $\begin{array}{l}\text { Sts (N) } \\
\text { Sts (K) } \\
\text { X (w.r.) }\end{array}$ & \\
\hline $\begin{array}{l}\text { 33-1, 138-140 } \\
\text { (Flow Unit 6B) }\end{array}$ & Same as 33-1, & $5-137$ & & & & & & & & & $\begin{array}{l}\text { pts } \\
\text { C.A. } \\
X(\text { w.r. })\end{array}$ & $\begin{array}{l}\text { In reflected light complex } \\
\text { magnetite ilmenite intergrowths } \\
\text { are scattered throughout the rock; } \\
\text { a very few ilmenite laths are } \\
\text { present in formerly glassy areas. }\end{array}$ \\
\hline $\begin{array}{l}\text { 33-2, 79-81 } \\
\text { (Flow Unit 6B) }\end{array}$ & Aphyric & & & 8.5 & $0.5-2.0$ & 1.0 & 91.5 & $<0.4$ & $\begin{array}{l}\text { Diabasic- } \\
\text { intersertal }\end{array}$ & Same as $33-1,135-137$ & $\begin{array}{l}\text { Sts }(N) \\
\text { Sts (K) } \\
\text { X (w.r.) }\end{array}$ & \\
\hline $\begin{array}{l}\text { 33-2, 82-84 } \\
\text { (Flow Unit 6B) }\end{array}$ & Same as 33-2, & & & & & & & & & & $\begin{array}{l}\text { pts } \\
\text { C.A. } \\
\text { X (w.r.) } \\
X \text { (v.f.) }\end{array}$ & $\begin{array}{l}\text { Same as } 33-1,138-140 \\
\text { X-ray vesicle filling shows possible } \\
\text { celadonite }\end{array}$ \\
\hline $\begin{array}{l}\text { 33-3, 91-93 } \\
\text { (Flow Unit 6B) }\end{array}$ & Aphyric & & & 9.0 & $0.5-1.5$ & 0.8 & 91.0 & $<0.4$ & $\begin{array}{l}\text { Diabasic- } \\
\text { intersertal }\end{array}$ & $\begin{array}{l}\text { Moderately altered basalt; ground- } \\
\text { mass pyroxene (augite and Ca-poor } \\
\text { augite) and plagioclase fresh; former } \\
\text { groundmass glass is more abundant } \\
\text { than } 33-1,135-137 \text { and } 33-2,79-81 \\
\text { and completely altered to brown } \\
\text { monttmorillonite; vesicles are filled } \\
\text { with green montmorillonite; no calcite } \\
\text { is seen in the section or X-ray diffrac- } \\
\text { tion pattern }\end{array}$ & $\begin{array}{l}\text { Sts }(\mathrm{N}) \\
\text { Sts (K) } \\
X(\text { w.r.) } \\
\text { X (v.f.) }\end{array}$ & \\
\hline $\begin{array}{l}\text { 33-3, 94-96 } \\
\text { (Flow Unit 6B) }\end{array}$ & Same as $33-3$, & & & & & & & & & & $\begin{array}{l}\text { pts } \\
\text { C.A. } \\
\text { X (w.r.) } \\
\text { X (v.f.) }\end{array}$ & $\begin{array}{l}\text { In reflected light opaques are about } \\
\text { equally divided between complex } \\
\text { magnetite-ilmenite intergrowths, } \\
\text { free ilmenite, and free pinkish } \\
\text { magnetite. Very sparse chalco- } \\
\text { pyrite blebs; some are intergrown } \\
\text { with pyrrhotite }\end{array}$ \\
\hline $\begin{array}{l}\text { 33-3, 102-104 } \\
\text { (Flow Unit 6B) }\end{array}$ & Aphyric & & & 5.5 & $0.5-1.5$ & 0.8 & 94.5 & $<0.3$ & $\begin{array}{l}\text { Diabasic- } \\
\text { intersertal }\end{array}$ & $\begin{array}{l}\text { Same as } 33-3,91-93 \text {, but contains } \\
\text { less vesicles, considerably less altered } \\
\text { groundmass glass, and is finer } \\
\text { grained }\end{array}$ & $\begin{array}{l}\text { pts } \\
X \text { (w.r.) } \\
X \text { (v.f.) } \\
\text { K/A (w.r.) }\end{array}$ & $\begin{array}{l}\text { In reflected light, is similar to } 33-3 \text {, } \\
94-96 \text { but finer grained }\end{array}$ \\
\hline $\begin{array}{l}33-3,110-114 \\
\text { Coherent, partially } \\
\text { baked siltstone with } \\
\text { incipient hornfels } \\
\text { texture }\end{array}$ & & & & & & & & & & & $X(w . r)$. & $\begin{array}{l}\text { X-ray mineralogy (in order of } \\
\text { abundance); plagioclase, pyroxene; } \\
\text { heulandite; montmorillonite; } \\
\text { quartz; celadonite; and pyrite }\end{array}$ \\
\hline $\begin{array}{l}33-3,124-128 \\
\text { Coherent, partially } \\
\text { baked siltstone }\end{array}$ & & & & & & & & & & & $\mathrm{X}$ (w.r.) & $\begin{array}{l}\text { X-ray mineralogy (in order of } \\
\text { decreasing abundance), } \\
\text { plagioclase; pyroxene; celadonite; } \\
\text { montmorillonite; quartz; and pyrite }\end{array}$ \\
\hline
\end{tabular}




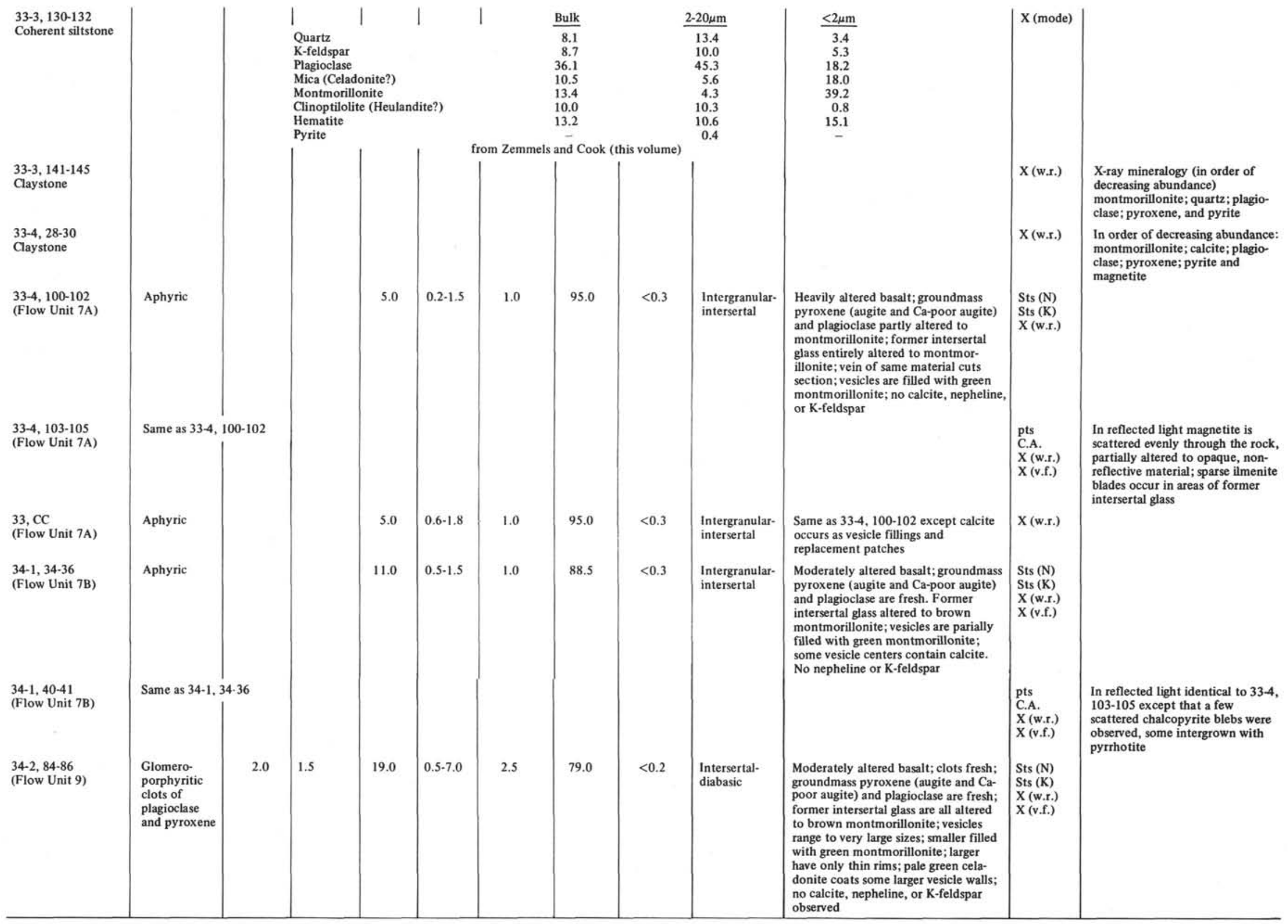


TABLE 4 - Continued

\begin{tabular}{|c|c|c|c|c|c|c|c|c|c|c|c|c|}
\hline \multirow[b]{2}{*}{$\begin{array}{c}\text { Sample } \\
\text { (Interval in } \mathrm{cm} \text { ) }\end{array}$} & \multicolumn{3}{|c|}{$\begin{array}{l}\text { Phenocrysts and } \\
\text { Microphenocrysts }\end{array}$} & \multicolumn{3}{|c|}{ Vesicles $^{\mathrm{a}}$} & \multicolumn{3}{|c|}{ Groundmass $^{\mathrm{a}}$} & \multirow[b]{2}{*}{ Alteration } & \multirow[b]{2}{*}{$\begin{array}{l}\text { Other } \\
\text { Workb }\end{array}$} & \multirow[b]{2}{*}{ Remarks } \\
\hline & Mineral & Percent & $\begin{array}{l}\text { Average } \\
\text { Size (mm) }\end{array}$ & Percent & $\begin{array}{c}\text { Size } \\
\text { Range }\end{array}$ & $\begin{array}{l}\text { Average } \\
\text { Size (mm) }\end{array}$ & Percent & $\begin{array}{l}\text { Average } \\
\text { Size (mm) }\end{array}$ & $\begin{array}{l}\text { Dominant } \\
\text { Texture }\end{array}$ & & & \\
\hline $\begin{array}{l}\text { 34-2, 91-93 } \\
\text { (Flow Unit 9) }\end{array}$ & Same as $34-2,84$ & & & & & & & & & & $\begin{array}{l}\text { pts } \\
\text { C.A. } \\
X \text { (w.r.) } \\
X \text { (v.f.) }\end{array}$ & $\begin{array}{l}\text { In reflected light, magnetite is } \\
\text { scattered evenly throughout the } \\
\text { rock, partially replaced by an } \\
\text { opaque, nonreflective material; } \\
\text { sparse ilmenite occurs as blocky } \\
\text { grains and laths }\end{array}$ \\
\hline $\begin{array}{l}\text { 34-3, 115-117 } \\
\text { (Flow Unit 10) }\end{array}$ & Aphyric & & & 26.5 & $0.5-10.0$ & 5.0 & 73.5 & $<0.05$ & Vitrophyric & $\begin{array}{l}\text { Moderately altered rock; microlites } \\
\text { of pyroxene (augite and Ca-poor } \\
\text { augite) and plagioclase are fresh; } \\
\text { former groundmass glass ( } \sim 50 \% \text { of } \\
\text { non-vesicular part of the rock) is } \\
\text { completely altered to brown mont- } \\
\text { morillonite; huge vesicles are largely } \\
\text { open with thin rims of green mont- } \\
\text { morillonite; some greenish celadonite } \\
\text { replacing groundmass; small amounts } \\
\text { of calcite is observed in section; no } \\
K \text {-feldspar }\end{array}$ & $\begin{array}{l}\text { Sts }(K) \\
\text { X (w.r.) } \\
\text { X (v.f.) }\end{array}$ & $\begin{array}{l}\text { Heulandite identified in vesicle } \\
\text { filling by X-ray diffraction }\end{array}$ \\
\hline $\begin{array}{l}\text { 34-3, 118-120 } \\
\text { (Flow Unit 10) }\end{array}$ & Same as $34-3,11$ & $5-117$ & & & & & & & & No nepheline is present & $\begin{array}{l}\text { pts } \\
\text { C.A. } \\
\text { Sts (N) } \\
\text { X (w.r.) } \\
\text { X (v.f.) }\end{array}$ & $\begin{array}{l}\text { In reflected light tiny crystals of } \\
\text { magnetite are scattered evenly } \\
\text { through rock, partially altered } \\
\text { to an opaque nonreflective sub- } \\
\text { stance; a few ilmenite laths and } \\
\text { minute chalcopyrite blebs are } \\
\text { present }\end{array}$ \\
\hline $\begin{array}{l}\text { 34-4, 62-64 } \\
\text { (Flow Unit 10) }\end{array}$ & $\begin{array}{l}\text { Glomero- } \\
\text { porphyritic } \\
\text { clots of } \\
\text { pyroxene and } \\
\text { plagioclase }\end{array}$ & 8.0 & 1.6 & 18.5 & $2.0-8.0$ & 5.0 & 73.5 & $<0.05$ & Vitrophyric & $\begin{array}{l}\text { Same as } 34-3,115-117 \text { except for } \\
\text { presence of unal tered clots and the } \\
\text { presence of somewhat more calcite }\end{array}$ & $\begin{array}{l}\text { Sts (K) } \\
X \text { (w.r.) } \\
X \text { (v.f.) }\end{array}$ & \\
\hline $34-4,65-67$ & Same as $34-4,62$ & & & & & & & & & & $\begin{array}{l}\text { pts } \\
\text { C.A. } \\
X(w . r .) \\
X(v . f .)\end{array}$ & $\begin{array}{l}\text { In reflected light, same as } \\
34-3,118-120\end{array}$ \\
\hline $34, \mathrm{CC}$ & $\begin{array}{l}\text { Glomero- } \\
\text { porphyritic } \\
\text { clots of } \\
\text { pyroxene and } \\
\text { plagioclase }\end{array}$ & 17.0 & 1.0 & 7.0 & $2.0-10.0$ & 5.0 & 76.0 & $<0.05$ & Vitrophyric & $\begin{array}{l}\text { Same as } 34-4,62-64 \text { except contains } \\
\text { more clots and less vesicles }\end{array}$ & $X$ (w.r.) & \\
\hline
\end{tabular}

${ }^{a}$ Average points counted 300 ; percentages rounded to nearest $0.5 \%$.

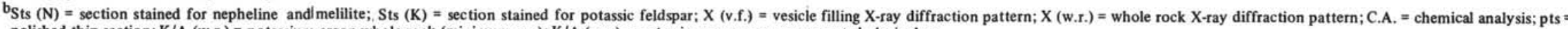
polished thin section; $\mathrm{K} / \mathrm{A}(\mathrm{w} . \mathrm{r})=$. potassium argon whole-rock (minimum age); $\mathrm{K} / \mathrm{A}(\mathrm{p} . \mathrm{c})=$. potassium argon age on separated plagioclase. 